\title{
Expertise van huisartsen : praktijkervaring, kennis en diagnostische hypothesevorming
}

Citation for published version (APA):

Hobus, P. (1994). Expertise van huisartsen : praktijkervaring, kennis en diagnostische hypothesevorming. [Doctoral Thesis, Maastricht University]. Rijksuniversiteit Limburg.

https://doi.org/10.26481/dis.19940429ph

Document status and date:

Published: 01/01/1994

DOI:

10.26481/dis.19940429ph

Document Version:

Publisher's PDF, also known as Version of record

\section{Please check the document version of this publication:}

- A submitted manuscript is the version of the article upon submission and before peer-review. There can be important differences between the submitted version and the official published version of record.

People interested in the research are advised to contact the author for the final version of the publication, or visit the DOI to the publisher's website.

- The final author version and the galley proof are versions of the publication after peer review.

- The final published version features the final layout of the paper including the volume, issue and page numbers.

Link to publication

\footnotetext{
General rights rights.

- You may freely distribute the URL identifying the publication in the public portal. please follow below link for the End User Agreement:

www.umlib.nl/taverne-license

Take down policy

If you believe that this document breaches copyright please contact us at:

repository@maastrichtuniversity.nl

providing details and we will investigate your claim.
}

Copyright and moral rights for the publications made accessible in the public portal are retained by the authors and/or other copyright owners and it is a condition of accessing publications that users recognise and abide by the legal requirements associated with these

- Users may download and print one copy of any publication from the public portal for the purpose of private study or research.

- You may not further distribute the material or use it for any profit-making activity or commercial gain

If the publication is distributed under the terms of Article $25 \mathrm{fa}$ of the Dutch Copyright Act, indicated by the "Taverne" license above, 


\section{EXPERTISE VAN HUISARTSEN}


ИaहTя A 


\section{EXPERTISE VAN HUISARTSEN}

\section{PRAKTIJKERVARING, KENNIS EN DIAGNOSTISCHE HYPOTHESEVORMING}

\section{PROEFSCHRIFT}

ter verkrijging van de graad van doctor aan de Rijksuniversiteit Limburg te Maastricht, op gezag van de Rector Magnificus, Prof. dr. H. Philipsen, volgens het besluit van het College van Dekanen, in het openbaar te verdedigen op vrijdag,

29 april 1994 om 14.00 uur

door

Pie Hobus

geboren te Roggel in 1956 


\section{PROMOTOR}

Prof. dr. H.G. Schmidt

\section{CO-PROMOTOR}

Dr. H.P.A. Boshuizen

\section{BEOORDELINGSCOMMISSIE}

Prof. dr. A.P.W.M. Appels (voorzitter)

Dr. P.A.J. Bouhuijs

Prof. dr. mr. R.P.T.M. Grol

Prof. dr. J.C.M. Metz (Katholieke Universiteit Nijmegen)

Prof. dr. H.J.M. van Rossum (Rijksuniversiteit Groningen)

De uitgave van dit proefschrift kwam mede tot stand door een bijdrage van de firma E. Merck, Nederland BV te Amsterdam. 
Aan mijn vader en ter nagedachtenis aan mijn moeder 


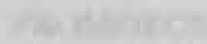

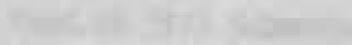

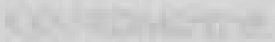

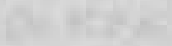

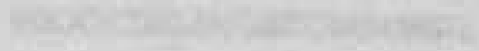

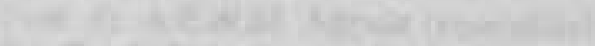

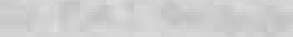

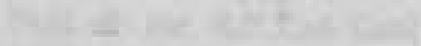

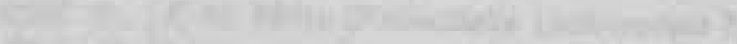

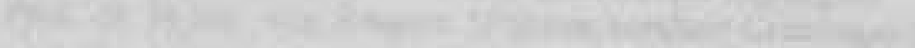

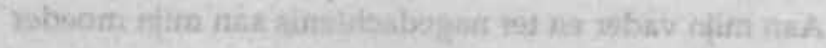

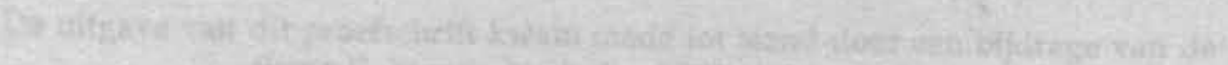

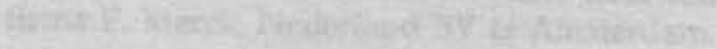




\section{INHOUDSOPGAVE}

Hoofdstuk 1 Inleiding 1

Protocol van een spreekuur 2

Vroege diagnostische hypothesen $\quad 7$

Twee benaderingen van het onderzoek naar diagnostisch denken 11

Cognitief-psychologische theorievorming 13

Kenmerken van de informatie in de beginfase van het consult 21

Vraagstelling 22

Overzicht van experimenten 24

Referenties 25

Hoofdstuk 2 Contextual Factors in the Activation of First Diagnostic

Hypotheses: Expert-Novice Differences 31

Summary $\quad 32$

Introduction 33

Method $\quad 34$

Results $\quad 37$

Discussion $\quad 38$

Conclusion $\quad 39$

References 39

Hoofdstuk 3 De Context van de Klacht als Diagnosticum 41

Samenvatting $\quad 42$

Inleiding $\quad 43$

Methoden

Resultaten $\quad \mathbf{4 7}$

Beschouwing $\quad 48$

Referenties $\quad 50$

Synopsis

The context of the complaint as a diagnostic tool 52

Hoofdstuk 4 De Invloed van Ervaring op Diagnostische Prestaties

van Huisartsen $\quad 55$

Samenvatting $\quad 56$

Inleiding $\quad 57$

Methoden $\quad 58$

Resultaten $\quad 59$ 
Beschouwing

Referenties

Synopsis

The influence of experience on GPs' diagnostic performance

Hoofdstuk 5 What Causes Early Diagnostic Hypotheses To Be Activated:

Context or Complaint?

Summary

Introduction

Method

Results

Discussion

81

Conclusion

85

References

Hoofdstuk 6 Expert-Novice Differences in the Mental Representations of Patient Prototypes

Summary

Introduction

Method

Results

93

Discussion

94

References

95

Hoofdstuk 7 Samenvatting en Implicaties

Inleiding

De invloed van contextuele kennis op diagnostische prestaties

Betekenis van deze bevindingen voor een theorie over

de ontwikkeling van ziekte scripts

Implicaties voor het medisch onderwijs

Implicaties voor de huisartsgeneeskunde

Implicaties voor de kwaliteitsbevordering in de

huisartsgeneeskunde

Implicaties voor de automatisering in de huisartsgeneeskunde. 118

Referenties

Summary

Dankwoord 


\section{INLEIDING}


Het spreekuur confronteert een huisarts met een groot aantal verschillende klachten en problemen. De patiënt doet een beroep op hem om van zijn kwaal te genezen of om een antwoord te krijgen op de vraag wat hem mankeert. Uit het ongestruktureerde verhaal van de patiënt tracht de huisarts af te leiden welke symptomen zich bij zijn patiënt voordoen en welke ziekte hiervoor verantwoordelijk is. In het mentale zoekproces dat hiermee gepaard gaat, spelen voorlopige hypothesen omtrent de aard van de aandoening een belangrijke rol. $\mathrm{Zij}$ dienen als uitgangspunten waaraan beschikbare gegevens worden geïnterpreteerd en gerelateerd en van waaruit navraag geschiedt naar nog ontbrekende gegevens. In dit proefschrift doet de auteur verslag van onderzoek bij huisartsen naar factoren die het ontstaan van dergelijke voorlopige diagnostische hypothesen beïnvloeden.

Om een indruk te geven van het denkproces van huisartsen, wordt dit hoofdstuk begonnen met de weergave van de gedachtenstroom van een huisarts naar aanleiding van contacten met patiënten. Aan de hand van dit voorbeeld zal ingegaan worden op enkele algemene kenmerken van huisartsgeneeskundige diagnostiek. Daarna zal besproken worden wat hierin de rol van vroege hypothesevorming is.

Vervolgens zullen in deze inleiding twee algemeen gangbare benaderingen van het onderzoek naar het denken van artsen besproken worden. Éen van deze benaderingen, de cognitief-psychologische, waarbij de nadruk ligt op het kennisgebruik tijdens het oplossen van (medische) problemen, zal nader worden toegelicht aan de hand van ontwikkelingen in het onderzoek naar medisch probleemoplossen. Hierbij staat de auteur stil bij het theoretisch model dat een centrale rol speelt in dit proefschrift: het zogenaamde ziekte script of 'illness script'. Op basis van dit model wordt tenslotte de vraagstelling gepresenteerd welke verder wordt uitgewerkt in concrete hypothesen met de daaraan gekoppelde experimenten.

\section{Protocol van een spreekuur}

Op een spreekuur van de auteur van dit proefschrift meldden zich 18 patiënten die een aantal mentale reacties opriepen. Onderstaande tabel bevat deze reacties, gedachten en handelingen. Het protocol is direct na afloop van dat spreekuur opgeschreven op basis van aantekeningen gemaakt tijdens het spreekuur. Het protocol illustreert de aard van de klachten waarmee mensen een 'gewoon' spreekuur bezoeken, en beschrijft de gedachten die de verschillende klachten bij een arts oproepen. ${ }^{1}$

\begin{tabular}{|l|l|l|}
\hline $\begin{array}{l}\mathbf{8} \text { uur15 } \\
\text { Mvr. A } 40 \text { jaar. }\end{array}$ & $\begin{array}{l}\text { "Moeilijk te behandelen hypertensie, net } \\
\text { terug uit het ziekenhuis." "Had haar ver- } \\
\text { wezen onder verdenking van obstruerende } \\
\text { choledochus-steen." "In 1985 had zij ieis } \\
\text { soortgelijks," "De galblaas was er in 1978 al } \\
\text { uitgegaan." }\end{array}$ \\
\hline
\end{tabular}

${ }^{1}$ De klachten, symptomen en bevindingen bij lichamelijk onderzoek zijn in normaal lettertype weergegeven, de gedachten die naar aanleiding daarvan opkwamen zijn vetgedrukt en tussen dubbele aanhalingstekens geplaatst. 


\begin{tabular}{|c|c|c|}
\hline & $\begin{array}{l}\text { Nu toename pijn rechteronderbuik sedert } \\
\text { het verwijderen van de drain. }\end{array}$ & "Welke drain, misschien een T - drain?" \\
\hline & $\begin{array}{l}\text { Pijin trekt naar boven en zit vast aan het } \\
\text { ademen }\end{array}$ & $\begin{array}{l}\text { "Dat moet iets in de buurt van het diafragma } \\
\text { of leverr zijn." "Zou er al een brief, van } \\
\text { chirurg ziln?" }\end{array}$ \\
\hline & $\begin{array}{l}\text { Heeft ERCP gehad. Men had hiermee de } \\
\text { obstructie niet kunnen opheffen, 'dat } \\
\text { nooit meer. }\end{array}$ & "Vervelende ingreep." \\
\hline & $\begin{array}{l}\text { Daama choledochotomie, veel steenfies, } \\
\text { postoperatief koorts, waarvoor antibio- } \\
\text { tica. }\end{array}$ & $\begin{array}{l}\text { "Zou ze nu een Abces hebben?" "Of mis- } \\
\text { schient weer choledochus stenen?" }\end{array}$ \\
\hline & $\begin{array}{l}\text { De pijn is meer continue, geen kolieken. } \\
\text { Geen koorts. Niet misselifk, normale kleur } \\
\text { ontlasting, wel een keer bloed gezien. }\end{array}$ & $\begin{array}{l}\text { "Dat bloed kan ik niet rijmen met de rest van } \\
\text { het verhaal." }\end{array}$ \\
\hline & Plassen gaat goed, geen kleurverandering. & $\begin{array}{l}\text { "Dus waarschijnlijk geen obstructie of abces, } \\
\text { mis schien gal-tekkage? }\end{array}$ \\
\hline & $\begin{array}{l}\text { Bij onderzoek een vast aanvoelende le- } \\
\text { verregio. }\end{array}$ & "Zou dalt nog; normaal zịnn ma zo'n ingreep? \\
\hline & Geen duidelijk peritoneale prikkeling. & $\begin{array}{l}\text { "Het beeld lijkil zeker niet op dat van v66r de } \\
\text { verwijzing." Adviseer haar wat eerder dan } \\
\text { gepland terug te gaan naar de chirurg. }\end{array}$ \\
\hline intis it & Patiënt voelt hier echter niet veel voor & $\begin{array}{l}\text { Die matige patiënt compliance herken ilk } \\
\text { van de matige resultaten bij de behandeling } \\
\text { van hatar bloeddrulk" } \mathrm{Zij} \text { is toch te overtuigen, } \\
\text { en zal tevens attent blijven op het bloedverlies per } \\
\text { anum. }\end{array}$ \\
\hline 8 uur 40 & & $\begin{array}{l}\text { "Begin nu al uit te lopen met het spreekuur, } \\
\text { beetje tempo maken." }\end{array}$ \\
\hline $\begin{array}{l}\text { Jongetje B 4,5 } \\
\text { jaar. }\end{array}$ & & $\begin{array}{l}\text { "Wat is die van de winter ziek geweest met } \\
\text { zijn pneumonie, zal nu ook wel weer tets } \\
\text { vanwege zijn CARA zijn." "Inderdaad:" }\end{array}$ \\
\hline & $\begin{array}{l}3 \text { dagen koorts met toename van piepen en } \\
\text { hoesten. }\end{array}$ & "Wel of nielt antibiotica geven?" \\
\hline & $\begin{array}{l}\text { Geen groen sputum of snot, zusje hoest } \\
\text { ook. }\end{array}$ & $\begin{array}{l}\text { "Dan zal het wel een viraal infect zijn } \\
\text { waardoor aijn CARA meer opspeelt." "Is de } \\
\text { therapie wel voldoende?" }\end{array}$ \\
\hline & $\begin{array}{l}\text { Gebruikt nu Ventolin, Promethazine en } \\
\text { Fuimucil. Onderzoek: }\end{array}$ & "Leuk joch." \\
\hline$\overline{1}$ & $\begin{array}{l}\text { matig verlengd expirium, hier en daar wat } \\
\text { ronchi, keel en oren gio. }\end{array}$ & $\begin{array}{l}\text { "Zou toch de moeite waard zijn weer eens te } \\
\text { starten met Lomudal. " "jammer dar een. } \\
\text { voirige poging door zijn eenkennigheid } \\
\text { mislukt: is." Consult wordt afgesloten met het } \\
\text { plan nog eens een poging met Lomudal te onder- } \\
\text { nemen. Tevens nu Aminofyline zetpilleri gaan } \\
\text { gebruiker. }\end{array}$ \\
\hline $\begin{array}{l}9 \text { uur } 05 \\
\text { Mvr. C, } 57 \text { jaar. }\end{array}$ & $132=$ & $\begin{array}{l}\text { "Hoe zou haar teen eruit zien?" "Daar in zij } \\
\text { nu al } 4 \text { maanden mee aan het dokteren! " } \\
\text { "Hopelijk gaat het wat beter nu we die } \\
\text { diabetes ontdekt en behandeld hebben." }\end{array}$ \\
\hline & $\begin{array}{l}\text { Geen pijin meer. Kan gesloten schoenen } \\
\text { zonder problemen de hele dag dragen. De } \\
\text { destijds onstoken clavus digit Il ziet er } \\
\text { rustig uit. }\end{array}$ & "Effect van Daktarin?" \\
\hline & eeltvorming is een siuk minder. & $\begin{array}{l}\text { "Komi warschijnlijk door teenspreider.". } \\
\text { "Glucose prikken en tensiecontrole stellen } \\
\text { we nu maar uit l.v.m. drukte." Docirgaan zo. }\end{array}$ \\
\hline $\begin{array}{l}9 \text { uur15 } \\
\text { Mvr. D. } 50 \text { jaar. }\end{array}$ & Wil bloeddruk laten controleren. & "Hopelijk is dat het: enige." \\
\hline tow anter & $\begin{array}{l}\text { Tevens pijinklachten ter hoogte van inker } \\
\text { thorax helft. Op de: kaart: half jaar } \\
\text { geleclen ook al gemeld: behoudens wat } \\
\text { gevoelige costosternale overgang niks } \\
\text { gevonden toen. }\end{array}$ & "Zal wel weer hetzelfde zij, n." \\
\hline & Ook pijn in bovenbuik. & "Dat is nieuw. Maagklachten?" \\
\hline & $\begin{array}{l}\text { Geen zuurbranden of braken. Eetlust } \\
\text { goed. }\end{array}$ & "Blịpft dus onduidelịik." \\
\hline & $\begin{array}{l}\text { Geen epigastriale drukpijin wel op } \\
\text { costosternale overgang. }\end{array}$ & $\begin{array}{l}\text { "Dus toch hetzelfde als half jaar geleden!" } \\
\text { Tensoplast erover. Recept Dyta-urese verlengd. }\end{array}$ \\
\hline
\end{tabular}




\begin{tabular}{|c|c|c|}
\hline $\begin{array}{l}9 \text { uur } 30 \\
\text { Meisje E. } 19 \\
\text { jaar. }\end{array}$ & Al een week keelpijn, & "Streptococcenı infect?" \\
\hline & Geen koorts, wel siikpijn. Hoest niet. & "Wel of niet antibiotica geven? Even kijken." \\
\hline & Vieze tonsillen met forse lymfeklieren. & $\begin{array}{l}\text { "Dat had ilk niet verwacht vanwege het } \\
\text { ontbreken van koorts." Kuurtje Broxil. } \\
\text { Gongelen met zoutwater. }\end{array}$ \\
\hline 9 นน $\$ 0$ & & $\begin{array}{l}\text { "Nog maar cen patiënt in de wachtkamer. " } \\
\text { "Ik begin weer aardig in te lopen." }\end{array}$ \\
\hline Dhr. F. 66 jaar. & $\begin{array}{l}\text { staat zoals gewoonlijk aan de balie uit- } \\
\text { gebreid te verhalen over zịn leven en de } \\
\text { rol van dieren daarin. }\end{array}$ & $\begin{array}{l}\text { "Die komt vast voor bloeddruk controle." } \\
\text { "Waaromi wil die niet omlaag? " "Slechte pa- } \\
\text { tiënt-contpliance? " }\end{array}$ \\
\hline & Tensie nu $140 / 100$ & "Therapie nog magr even laten zo." \\
\hline & $\begin{array}{l}\text { "Verkoudheic" is wat minder maar nu } \\
\text { wel last van brandende tong. }\end{array}$ & $\begin{array}{l}\text { "Ik had hem antibiotica gegeven zou die daar } \\
\text { nu cen Monilia van gekiregen hebben?" }\end{array}$ \\
\hline & Lifkt er niet zo op bij onderzoek. & $\begin{array}{l}\text { Toch maar recept Nystatime orale suspensie. Over } \\
\text { twee weken terugkornen. }\end{array}$ \\
\hline $\begin{array}{l}9 \text { uur } 50 \\
\text { Mvr. G. } 56 \text { jaar. }\end{array}$ & $\begin{array}{l}\text { Controle na trauma li onderbeen } 4 \text { dgn } \\
\text { geleden. }\end{array}$ & "Röntgen lielk geen fractuur: zien." \\
\hline & $\begin{array}{l}\text { Zij heeft nog veel pijn van het forse hema- } \\
\text { toom. Maakt zich erg druk. }\end{array}$ & $\begin{array}{l}\text { "Bekende nerveuze gejaagdheid. " "Had ik } \\
\text { haar nielt al eensi op hyperthyreoidie ge- } \\
\text { screend?" }\end{array}$ \\
\hline & $\begin{array}{l}\text { Onduidelijk verhaal over onmogelijkheid } \\
\text { tot operatie aan knobbels onderbenen, } \\
\text { zou fe gevaarlijk zijn had de specialist } \\
\text { gezegd. Alleen iets over varices op de } \\
\text { kaart te vinden. }\end{array}$ & $\begin{array}{l}\text { "Z,al wel een misverstand van haar kant zijn. } \\
\text { "Zlet er niet nalar uit dat ze geopereerd moet } \\
\text { worden."Gerustgesteld en opnieuw verbonden. }\end{array}$ \\
\hline $\begin{array}{l}10 \text { uur } 05 \\
\text { Dhr. H. } 37 \text { jaar. }\end{array}$ & & $\begin{array}{l}\text { "Zal wel voor retropatellair chondropathie of } \\
\text { bloeddruk of beide komen." }\end{array}$ \\
\hline & $\begin{array}{l}\text { Gaat redelijk, nog alleen last bij traplo- } \\
\text { pen. Afvallen lukt nog niet zo best omdat } \\
\text { hij minder loopt nu hij niet kan werken. }\end{array}$ & $\begin{array}{l}\text { "Afvallien moet toch ook kunnen lukken bij } \\
\text { weinig lichaamsbeweging! }\end{array}$ \\
\hline & $\begin{array}{l}\text { Bekent dat hij wel vaker zondigt en riet } \\
\text { echt zijn best doet. RR } 150 / 110 \text {, gewicht } \\
112 \mathrm{~kg} \text { Zelfmetingen thuis: diastool rond } \\
\text { de } 85 \text {. }\end{array}$ & $\begin{array}{l}\text { "Voordeel van de twijfel." Fysiotherapie en } \\
\text { continueren Capozide. }\end{array}$ \\
\hline $\begin{array}{l}10 \text { uนr } 20 \\
\text { Dhr. I. } 38 \text { jaar. }\end{array}$ & 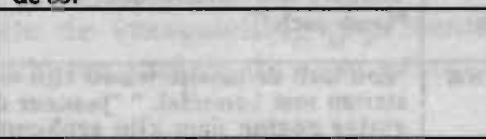 & $\begin{array}{l}\text { "Tijdje niet gezien. "Drie maanden geleden } \\
\text { langdurig geklaagd over zijn builk i.v.m. een } \\
\text { Salmonella dragerschap." "Na Noroxin kuur } \\
\text { was de faeceskwreek negatief. " "Zou hij weer } \\
\text { buikklachten hebben?" }\end{array}$ \\
\hline & $\begin{array}{l}\text { Persisterende schouderpijn na lokaal } \\
\text { Lidocaine injectie van waarnemer. Bij } \\
\text { onderzoek bursitis subacromialis. }\end{array}$ & $\begin{array}{l}\text { "Injectie Lidocaine dus onvoldoende effec- } \\
\text { tief." "Overgaan op lokal corticosteroid?" }\end{array}$ \\
\hline & Pationt voelt nuts voor "hormonenspuit". & $\begin{array}{l}\text { Lidocaine injectie herhaald. Advies: koelen en } \\
\text { later defenes. Oefenschema meegegever. }\end{array}$ \\
\hline $\begin{array}{l}10 \text { uur 30 } \\
\text { Dhr. J.42 jaar. }\end{array}$ & +7 & $\begin{array}{l}\text { "Had mictieklachten, nu bij uroloog, onder } \\
\text { behandeling." }\end{array}$ \\
\hline & $\begin{array}{l}\text { Conjunctivitis, rhinitis, pharyngitis ver- } \\
\text { haal. }\end{array}$ & "Hooilkoorts, Reiter?" \\
\hline & leder voorjaar 1-2 weker, last. & $\begin{array}{l}\text { "Boompollen allergie?" "Misschlen zinvol } \\
\text { nog eent zo'n set huidtesten aan te schaffen." }\end{array}$ \\
\hline & Slijmvliezen bleek livide aspect. & "Dus hooikforts." Recept. antihistaminicum. \\
\hline $\begin{array}{l}10 \text { uนr } 40 \\
\text { Mvr. K. } 33 \text { jaar. }\end{array}$ & t & $\begin{array}{l}\text { "Tas bevallen, zal dus wel voor de pil kò- } \\
\text { ment." }\end{array}$ \\
\hline & Sinusitis verhaal en dito onderzoek. & $\begin{array}{l}\text { "Zekeir wat matige weersiand i.v.m. bevalling } \\
\text { en atopische constitutie." Antibiotica, stomen en } \\
\text { neusdruppels. }\end{array}$ \\
\hline & Nekpijn schouderpiịn. Myalgie. & $\begin{array}{l}\text { "Zou ze haar spieren wal overbelast hebben } \\
\text { bij de bevalling?" }\end{array}$ \\
\hline & $\begin{array}{l}\text { Zou best mogelijk zijn. Alles gaat goed met } \\
\text { de kleine. Moest wel weer even wennen. }\end{array}$ & $\begin{array}{l}\text { "Dat had inderdaac jaren geduund tussen de } \\
\text { eerste un die tweede!" }\end{array}$ \\
\hline $\begin{array}{l}10 \text { uur } 50 \\
\text { Dhr. L. } 59 \text { jaar. }\end{array}$ & 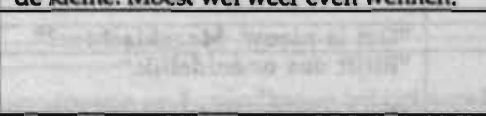 & $\begin{array}{l}\text { "Al yaak lokkail xylocaine voor bursitis sub- } \\
\text { trechanterica gespoten." "Recente foto van } \\
\text { heupen liet toch lichtie artrosis zlen." "Vorig } \\
\text { consult was moeilijk to plaatgen klachten." }\end{array}$ \\
\hline & $\begin{array}{l}\text { Gevpelloosheid en acute episoden, van } \\
\text { controle verlies re, heup waren spontaan } \\
\text { minder geworden. }\end{array}$ & $\begin{array}{l}\text { "Stugge roker, voor alle zekerheid nog even } \\
\text { de perifere pulsaties voelen." "Wel of niet } \\
\text { verwilzen?" "De kiachten duren al zo lang." }\end{array}$ \\
\hline
\end{tabular}




\begin{tabular}{|c|c|c|}
\hline 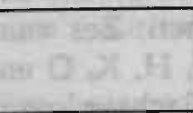 & $\begin{array}{l}\text { Pijinlijke matig beperkke endorotatie heup. } \\
\text { Pulsaties Art. Dorsalis Pedis beiderzijds } \\
\text { zwak. Verdere symptomen voor perifeer } \\
\text { arteriële vaatlijden afwezig. }\end{array}$ & $\begin{array}{l}\text { "Klachten waarschijnilijk toch voornamelijk } \\
\text { myogeen." Eerst fysiotherapie, indien weinig of } \\
\text { geen resultaat: verwijzen. }\end{array}$ \\
\hline \multirow[t]{2}{*}{$\begin{array}{l}11 \text { uur } 05 \\
\text { Dhr. M. } 50 \text { jaar }\end{array}$} & & "Zal wel bloeddiruk controle zijn." \\
\hline & RR 120/80, & recept Tenormin 50 \\
\hline \multirow[t]{2}{*}{$\begin{array}{l}11 \text { uur } 10 \\
\text { Mvr. N. } 26 \text { jaar. }\end{array}$} & & "Zwanger, bijna uitgeteld." \\
\hline & $\begin{array}{l}\text { Klassiek cystitis verhaal en dito urine } \\
\text { onderzoek. }\end{array}$ & $\begin{array}{l}\text { "Kan gebeuren zo op het einde van de } \\
\text { zwangerschap." Amoxycilline. }\end{array}$ \\
\hline \multirow[t]{7}{*}{$\begin{array}{l}11 \text { uur } 15 \\
\text { Dhr. } 0.69 \text { jaar }\end{array}$} & m:t: & $\begin{array}{l}\text { "Die komt niet vaaks voor zichzelf, wel met } \\
\text { zijn vrouw; die mankeert zoveel." "Ben be. } \\
\text { nieuwd." }\end{array}$ \\
\hline & $\begin{array}{l}\text { Griep gehad met koortsblaasje: } \\
\text { lijke dikke re, knie. }\end{array}$ & $\begin{array}{l}\text { "Gezien de voorafgaande virale infectie; } \\
\text { misschien calcium pyrofosfaat arthritis?" }\end{array}$ \\
\hline & $\begin{array}{l}\text { Bij onderzoek slechts lichte hydrops met } \\
\text { drukpijnlijk mediaal compartiment. }\end{array}$ & "Lijklt meeir op Artrosis." \\
\hline & $\begin{array}{l}\text { Inderdaad al lang wisselend last, tevens } \\
\text { ochtendstiffheid. }\end{array}$ & Foto maken. Rusten, Tubigrip en NSAID. \\
\hline & Last van nachteliijk plassen & $\begin{array}{l}\text { "Gezien de leeftijd: deco mpensatio co } \\
\text { "Prostaathypertrofie?" }\end{array}$ \\
\hline & $\begin{array}{l}\text { Geen dyspnoe d'effort, moeheid of dikke } \\
\text { enkels. Geen prostatisme verhaal, wel } \\
\text { mictiepiin aan penis. }\end{array}$ & "Cystitis, urethritis, prostatitis?" \\
\hline & $\begin{array}{l}\text { Rectaal toucher gladde niet pijnli } \\
\text { prostaat. Urine vol leuco's en er }\end{array}$ & $\begin{array}{l}\text { Kuurtie en over } 10 \text { dagen controle. "D } \\
\text { duidelijk hel: een en ander opgesp }\end{array}$ \\
\hline $\begin{array}{l}11 \text { uur } 40 \\
\text { Dhr. P. } 43 \text { jaar }\end{array}$ & & $\begin{array}{l}\text { "Morbus Darier." Nog steeds klachten over } \\
\text { pijnlijke handgewrichten?" }\end{array}$ \\
\hline & $\begin{array}{l}\text { Gaat niet beter met het 'eczeem' in oksels } \\
\text { en liezen. }\end{array}$ & $\begin{array}{l}\text { "O ja, dat had ik voor een mycose gehouden } \\
\text { en navenant behandeld." "Zou zoiets toch } \\
\text { met zijn M. Darrier te maken hebben?" } \\
\text { Opzoeken in de handboeken "Had ilk eigenlijk } \\
\text { eerder moeten doen." "Jawel hoor:" "exacer- } \\
\text { baties in lichaamsplooien". Recept Tetra 3\% in } \\
\text { Axungia met antihistaminicum. "Blijft zeldzaam } \\
\text { ziektebeeld." }\end{array}$ \\
\hline $\begin{array}{l}11 \text { uur } 55 \\
\text { Mvr. Q } 23 \text { jaar }\end{array}$ & +3 & $\begin{array}{l}\text { "Pas in de praktijk." "Ben benieuwd welke } \\
\text { klacht nu gepresenteerd zal gaan worden." } \\
\text { "In die korte tijd dat zij in de praktijk is, } \\
\text { reeds met legio klachten op spreekuur ge- } \\
\text { weest." }\end{array}$ \\
\hline \multirow[t]{3}{*}{ 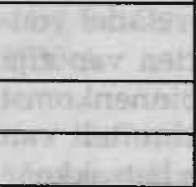 } & $\begin{array}{l}\text { Enkel klachten blijven. Vaak verzwik- } \\
\text { ken. Zeer lokaal drukpijnlijke mediale } \\
\text { malleolus. }\end{array}$ & "Surmenage" \\
\hline & $\begin{array}{l}\text { Aspecifieke buikklachten met pijn anus } \\
\text { bijzitten. }\end{array}$ & $\begin{array}{l}\text { "De patient tot nu toe kennend } \\
\text { colon?" }\end{array}$ \\
\hline & $\begin{array}{l}\text { Wisselende defeacatie met obstipatie. } \\
\text { Gevoelig colon descendus. RT gb }\end{array}$ & $\begin{array}{l}\text { "Voorlopige hypothese spastisch colon blijfl } \\
\text { gehandhaafd," Dieet en bulkvormiers proberen. }\end{array}$ \\
\hline \multirow[t]{4}{*}{$\begin{array}{l}12 \text { uur } 10 \\
\text { Dhr. R } 65 \text { jaar }\end{array}$} & 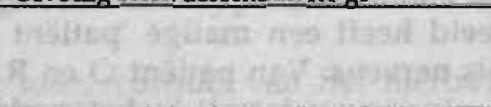 & $\begin{array}{l}\text { "Weer toename benatiwdheld?" "Pas nog } \\
\text { ziek te bed vanwege flinke dyspnoe door. } \\
\text { exacerbatie. CARA, longoedeem, en tijdelijk } \\
\text { atrium fibrilleren." }\end{array}$ \\
\hline & $\begin{array}{l}\text { Heeft al een tijdje "een knoer in de hals". } \\
\text { Pathologische lymfeklier re. supraclavi- } \\
\text { culair. Hard. }\end{array}$ & $\begin{array}{l}\text { "Niet pluis!" "Longtimmor?" "Had toch een } \\
\text { Bilrot, operatie in anamnese?" "Kan een } \\
\text { maagca rcinoom ook rechts supra claviculair } \\
\text { metastaseren?" }\end{array}$ \\
\hline & $\begin{array}{l}\text { Tevens enkele kliertjes in de oksels te } \\
\text { voelen. }\end{array}$ & $\begin{array}{l}\text { "Dain is een metastase van maag, of long } \\
\text { minder waarschijniijk, misschien een (Non- } \\
\text { Jifodgkin iymfoom?" }\end{array}$ \\
\hline & $\begin{array}{l}\text { Geen gewicht verloren, of overmatig } \\
\text { transpireren. }\end{array}$ & Verwezen naar internist. \\
\hline
\end{tabular}

Dit uitgebreide voorbeeld illustreert enerzijds een aantal kenmerken van de huisartsgeneeskundige situatie en anderzijds het diagnostisch denken dat daarin plaats- 
vindt. Wat allereerst opvalt, is de grote diversiteit aan klachten en problemen die de patiënten presenteren. Vaak presenteert een patiënt meerdere problemen. Zes van de achttien patiënten in het bovengeschetste spreekuur (patiënten $D, F, H, K, O$ en Q) hadden meer dan één klacht. Patiënt $O$ bijvoorbeeldi komt naast klachten over zijn artrotische knie tevens met een blaas- of prostaatontsteking. Een gang naar de huisarts voor een herhalingsrecept of bloeddrukcontrole vormit nogal eens de aanleiding om tevens een andere kwaal te berde te brengen. Gelukkig valt de ernst vain die kwalen dan meestal nogal mee. Patiënt $D$ bijvoorbeeld heeft niet meer dan een frequent voorkomende pijnklacht van de borstwand. Niet ieder consult: echter behelst de presentatie van een klacht en het inherente proces van anamnese en lichamelijk onderzoek. Bloeddrukcontroles of eenvoudige therapeutische ingrepen behoren evenzeer tot de inhoud van een consult. De klachten die gepresenteerd worden kunnen variëren van een onschuldige verkoudheidl of spierpijn (zie bijvoorbeeld Patiënte $K$ ) tot en met onbegrepen postoperatieve pijnen (Patiënte $A$ ) of verdachte lymfeklieren (Patiënt $R$ ). Klachten kunnen voortkomen uit een acute aandoening of optreden als gevolg van een onderliggend chronisch lijden. Patiënte E met haar acute tonsillitis en Patiëntje B met een exacerbatie van zijn chronisch obstructief longlijden zijn daar voorbeelden van. Een dergelijke diversiteit vloeit voort uit de positie van de huisarts in de eerste lijn. Die is over het algerneen de eerste persoon waar mensen met gezondheidsproblemen een beroep op doen.

Het vroege ziektestadium waarin patiënten hun klachten presenteren heeft tot gevolg dat de huisarts een ongedifferentieerd symptomenbeeld betekenis dient te geven. Dit gaat gepaard met een grote diagnostische onzekerheid (Bolinger \& Ahlers, 1975). Dat blijkt ook uit de diagnostische omschrijvingen in de gedachtenstroom van de huisarts in het bovenstaande voorbeeld. Het 'niet-pluis' gevoel bij de patiënt $\mathrm{R}$ met klieren in de hals, of de atypische buikklachten onder de noemer 'spastisch colon' van patiënte $Q$ die nog maar kort in de praktijk: is.

Kenmerkend voor de huisartsgeneeskunde is verder de zorg voor een relatief constante populatie. Daardoor is een huisarts bekend met de vroegere ziekten van zijn patiënt. In het voorbeeld denkt de huisarts in negen gevallen reeds bij binnenkomst van de patiënt aan vroegere ziekten of vorige consulten. Door de continuïteit van zorg weet de huisarts vaak al het én en ander over de manier waarop betrokkene met ziekte omgaat. Patiënt A bijvoorbeeld heeft een matige 'patiënt compliance', terwijl patiënten $\mathrm{G}$ en $Q$ te boek staan als nerveus. Van patiënt $\mathrm{O}$ en $\mathrm{R}$ verwacht de huisarts geen psychosomatische aandoeningen omdat zij in het verleden nauwelijks het spreekuur bezochten zoals in het geval van patiënt $O$, of omdat eerdere klachten een ernstig karakter droegen zoals bij patiënt $R$. Ook levenslloop en familieomstandigheden zijn hem ${ }^{1}$ bekend. Patiënte $\mathrm{K}$ bijvoorbeeld is net bevallen.

Door die continuilteit is hij eveneens in staat om, indien de omstandigheden dit toe laten, tijd als diagnosticum te gebruiken bij het vermoeden te maken te hebben met een zogenaamde 'self-limiting disease' zoals griep, of bepaalde klachten van het bewegingsapparaat. Soms wordt besloten bepaalde handelingen en beslissingen uit te

\footnotetext{
1 Uit stilistische overwegingen worden de aanduidingen 'hij/zij' en 'hem/haar'in dit proefschrift vermeden. Waar dit van toepassing is, worden met 'hij' en 'hem' beide geslachten bedoeld.
} 
stellen. Hij beslist bij vier van de achttien beschreven patiënten het 'even aan te zien' ( zie van Es, 1984).

Een huisarts ziet relatief veel mensen in korte tijd. In het voorbeeld zijn dat er 18 in 4 uur. Per dag ziet de gemiddelde Nederlandse huisarts ongeveer 1,5\% van de populatie van zijn praktijk. De daardoor ontstane tijdsdruk maakt beperkte diagnostiek onvermijdelijk. Beperkt wil zeggen dat meestal volstaan wordt met een korte anamnese en lichamelijk onderzoek (Brouwer, 1963; Crombie, 1963a, 1963b). Indien de huisarts hieruit niet duidelijk kan afleiden wat de precieze aard van de aandoening is, maar de ziekte weliswaar gecategoriseerd is als 'pluis', besluit hij vaak tot een proeftherapie of wordt de beslissing tot verwijzen uitgesteld. Een voorbeeld is patiënt $\mathrm{L}$, waarbij dit proces zich zelfs meerdere keren herhaalt. De gevoelloosheid en perioden van controleverlies van de rechter heup zijn eerst op proef behandeld met injecties in de bursa subtrochanterica alwaar lokale drukpijn bestond. Desondanks bleven de klachten, zij het in mindere mate, persisteren. Dit kon niet verklaard worden door de lichte artrosis die op een foto gezien werd. Even dacht de huisarts aan een vasculair probleem omdat patiënt een stugge roker is. Echter, omdat de perifere pulsaties aan de rechter voet niet verschillen met de pulsaties aan het andere been is ook deze oorzaak minder waarschijnlijk, waardoor de aandoening weer meer in de categorie pluis terecht komt en op proef fysiotherapie voorgeschreven wordt. Een dergelijk proefbehandeling is verder nog bij twee andere patiënten gegeven. Zo krijgt patiënte $Q$ met haar aspecifieke buikklachten bulkvormers mee, en patiënt $F$ met een brandende tong (na antibiotica) waaraan weinig te zien is, een antimycoticum.

Samengevat blijkt de situatie waarin huisartsgeneeskundige diagnostiek plaatsvindt, gekenmerkt te worden door een ongedifferentieerd aanbod van een groot aantal reeds bekende patiënten die de huisarts snel en met beperkte middelen diagnostisch tracht te classificeren. Niet altijd leidt dit tot een duidelijke diagnose en zal de geboden hulp dientengevolge een meer pragmatisch karakter krijgen (Crombie, 1963c).

\section{Vroege diagnostische hypothesen}

In nagenoeg ieder consult van het hierboven geschetste voorbeeld spelen al vrij vroeg diagnostische hypothesen door het hoofd van de huisarts. Dit is niet alleen kenmerkend voor de huisartsgeneeskundige diagnostiek (Gerritsma \& Smal, 1982). Ook specialisten werkzaam in ziekenhuizen, ja zelfs medische studenten proberen al in de vroege fase van het contact met de patiënt diagnostische hypothesen te ontwikkelen. Deze bevinding uit onderzoek naar medisch probleemoplossen kwam voor het eerst duidelijk naar voren in onderzoek van Elstein, Shulman en Sprafka (1978) en van Barrows, Neufeld, Feightner en Norman (1978). Dit gegeven staat in scherp contrast met de daarvoor geldende opvatting. Deze opvatting was dat artsen eerst alle relevante symptomen verzamelen door middel van anamnese en lichamelijk onderzoek, zonder daarbij aan specifieke diagnosen te denken. Pas daarna zouden de bevindingen geaggregeerd worden in een voorlopige differentiaal diag- 
nose. Aan de hand hiervan zouden verdere keuzen ten aanzien van laboratorium onderzoek en therapie tot stand komen (De Dombal, 1971; De Dombal, 1978; Ledley \& Lusted, 1959; Lusted, 1965; Formijne, 1971; Weed, 1968).

In het merendeel van het onderzoek naar het denken van artsen echter komt het fenomeen van vroege hypothesevorming consistent naar voren (Barrows, \& Bennet,1972; Boshuizen,1989; Gale \& Marsden, 1984; Gerritsma \& Smal, 1982; Kassirer \& Gorry, 1978; Leaper, Gill, Staniland, Horrocks, \& de Dombal, 1973; Pauker, Gorry, Kassirer, \& Schwartz, 1976; Ridderikhoff, 1986; Rooymans, 1969; Snoek, 1989; Wortman, 1966). De huisarts uit ons voorbeeld denkt bij nagenoeg iédere patiënt die niet voor één of andere controle komt, ruim voordat het lichamelijk onderzoek plaatsvindt, aan één of meerdere diagnostische hypothesen! Bij dié patiënten die wel voor een controle komen denkt hij al vroeg aan de mogelijke resultaten voortvloeiend uit het therapeutisch handelen in het vorige consult, zoals bij mevrouw $\mathrm{C}$ met een slecht genezende clavus aan haar teen, bij wie recent een diabetes type II ontdekt werd. Soms heeft de arts al voordat de klacht geuit is een hypothese in zijn hoofd zoals bij patiëntje B met zijn exacerbatie van CARA, of patiënt I waarvan hij vermoedt dat zijn buikklachten ten gevolge van een Salmonellose weer opspelen, of mevrouw $\mathrm{K}$ die pas bevallen is en nu misschien voor de pil komt. Het is dan ook niet onwaarschijnlijk dat de vroegere opvattingen over het diagnostisch denken van artsen eerder gebaseerd waren op 'wishful thinking' en gebruikelijke didactische methoden dan op de waarneming van het feitelijke gedrag van artsen (Dudley, 1975).

Het gegeven dat artsen al vroeg in een consult de op dat moment beschikbare informatie transformeren in medisch relevante termen is inherent aan de kenmerken van het menselijk geheugen (Baddeley, 1984; Miller, 1956; Newell \& Simon, 1972; Van der Kooij, 1978). Het korte-termijn geheugen is namelijk qua capaciteit sterk beperkt. De informatiestroom die tijdens een consult op gang komt is vaak omvangrijk en, oppervlakkig beschouwd, onsamenhangend. Vanwege de beperkte capaciteit van het korte termijn geheugen kan dergelijke informatie niet onbeperkt opgeslagen worden om pas op een later, en daardoor mogelijk geschikter moment geordend en geïnterpreteerd te worden. Daarentegen zal al vroeg in een consult informatie geclusterd worden in voorlopige hypothesen zodat ondanks de beperking van het korte termijn geheugen de arts in staat blijft nieuwe informatie op te nemen en te integreren. Tevens zal de arts aan de hand van deze voorlopige hypothese(n) zijn patiënt een aantal gerichte vragen kunnen stellen om gerezen vermoedens te toetsen. Dit op zijn beurt leidt weer tot meer structuur in het consult.

Kenmerkend daarbij is dat hij dan voornamelijk vragen stelt ter bevestiging en niet ter uitsluiting van de gerezen hypothese (Barrows, Neufeld, Feightner \& Norman, 1978; Elstein, Shulman \& Sprafka, 1978; Kassirer \& Gorry, 1978; Kern \& Doherty, 1982; Kleinmuntz, 1968). Dergelijk gedrag kan deels toegeschreven worden aan diagnostische onzekerheid aan het begin van een consult (Bolinger \& Ahlers, 1975; Ridderikhof, 1986; Slovic, Fischhoff, \& Lichtenstein, 1977). Eén en ander heeft onder meer tot gevolg dat een eenmaal gerezen hypothese niet gemakkelijk wordt losgela- 
ten (Krol, 1980; McWhinney, 1972) waardoor de inhoud van vroege hypothesen vaak overeenkomt met de uiteindelijke diagnose. In veel onderzoek komt dan ook een sterk verband tussen de kwaliteit van de eerste hypothesen en de kwaliteit van de uiteindelijke diagnose naar voren (Barrows, et al, 1978; Barrows, Norman, Neufeld, \& Feightner, 1982; Boshuizen 1989; Gale \& Marsden, 1984; Kassirer \& Gorry 1978; Neufeld, Norman, Feightner, Barrows, 1981; Snoek, 1989). Het: deels longitudinaal opgezette onderzoek van Barrows en medewerkers (1978) bijvoorbeeld, maakte gebruik van simulatiepatiënten. Met behulp hiervan werd het diagnostisch proces van 30 huisartsen, 32 internisten en 10 tot 34 studenten aan een nader onderzoek onderworpen. In deze exploratieve studie zijn zeer vele variabelen van het diagnostisch denken onderzocht: de duur van het consult, het aantal gestelde vragen, het aantal gegenereerde hypothesen, hoe specifiek die waren, de handelingen bij lichamelijk onderzoek, het aantal gevonden relevante bevindingen, de kwaliteit van de arts-patiënt communicatie, etc. De meest opvallende bevinding bij dit onderzoek was dat de kwaliteit van de uitkomst van dit denken (uiteindelijke diagnose, management en therapie) het beste voorspeld werd door de kwaliteit van de eerste hypothesen.

De belangrijke rol van hypothesen tijdens diagnostiek ligt opgesloten in het feit dat zij de dragers zijn van geïnterpreteerde informatie die daardoor wordt samengevat. Tegelijkertijd sturen zij het zoeken naar nieuwe relevante informatie. Daarom ook spelen vroege hypothesen vooral in de huisartsgeneeskundige diagnostiek een belangrijke rol. Immers naarmate het diagnostisch proces vooraf minder door routines en regels gestructureerd is, zoals bij vele specialismen wél het geval is, zal de uitkomst van het proces meer afhankelijk zijn van de soort en de kwaliteit van de gegenereerde hypothesen (Gerritsma \& Smal, 1982; Everwijn \& De Melker, 1985).

Het feit dat nog slechts weinig bekend is over de wijze waarop vroege hypothesen ontstaan, en omdat die in een ongestructureerde omgeving als die van de huisartsgeneeskunde zo'n belangrijke sturende rol spelen, gaf ondermeer aanleiding tot het in dit proefschrift gepresenteerde onderzoek.

Hiermee problematiseren we een bekend verschijnsel. Veel literatuur geeft namelijk de indruk dat de manier waarop eerste hypothesen tot stand komen reeds verklaard is en duidt het mechanisme aan met klinische blik, patroonherkenning of intuïtie (Berne, 1977; Bolinger \& Ahlers, 1975; Dudley, 1968; Eddy \& Clanton, 1982; Van Es, 1984; Everwijn, \& De Melker, 1985; Gale \& Marsden, 1982; Kuyvenhoven \& Spreeuwenberg, 1984; De Melker, \& Touw-Otten, 1984; Moser, 1975; Norman, Tugwell, Feightner, Muzzin \& Jacoby, 1985; Overholt \& Galen, 1977; Pauker, Gorry, Kassirer \& Schwartz, 1976; Ridderikhof, 1986; Schadé \& Brouwer, 1987; Style, 1979; Van der Velden, 1983; Verhey, 1982; Wulff, 1980). Dergelijke begrippen geven mentale epifenomenen aan, maar verklaren niet waarom ze optreden of hoe de inhoud ervan bepaald wordt. Dudley (1968) bijvoorbeeld geefit aan dat het proces van patroonherkenning moeilijk te begrijpen is: Wordt het geobserveerde 'object' (bijvoorbeeld een medisch probleem) eerst opgesplitst in zijn verschillende componenten om pas daarna geanalyseerd te worden, of vindt directe analyse van het object plaats op basis van de globale uiterlijke vorm? Bolinger en Ahlers (1975) beweren dat patroonherkenning optreedt omdat daardoor diagnostische onzekerheid 
verminderd. Patroonherkenning zou in deze opvatting dus voortkomen uit de grote behoefte van artsen aan diagnostische zekerheid. Deze auteurs beweren verder dat artsen gedurende hun studie steeds betere kennis opbouwen over ziektebeelden die ze tijdens de diagnostiek vergelijken met het symptoombeeld van de patiënt. De auteurs voeren helaas geen wetenschappelijke bewijzen aan waarop deze veronderstelling gebaseerd is.

Overigens worden in géen van de hierboven vermelde artikelen pogingen ondernomen uitspraken over de precieze oorsprong en aard van het mechanisme te staven middels wetenschappelijke bewijzen. In het algemeen neemt men voetstoots aan dat patroonherkenning optreedt (Van Es, 1984; Kuyvenhoven, 1984; De Melker, \& Touw-Otten, 1984; Overholt \& Galen, 1977; Schadé \& Brouwer, 1987; Wulff, 1980; Van der Velden, 1983), en een 'verklaring' is voor gevonden fenomenen (Eddy \& Clanton, 1982; Norman, et al. 1985; Ridderikhof, 1986), die voortvloeit uit onbewuste processen (Berne, 1977; Style, 1979) of voortvloeit uit vroegere ervaringen met patiënten en epidemiologische kennis (McWhinney, 1972). In dit proefschrift echter willen we trachten de factoren te onderzoeken die het ontstaan en de inhoud van vroege diagnostische hypothesen beïnvloeden door aard en inhoud van de aanwezige informatie waaruit de huisarts op zo'n moment kan putten, te manipuleren.

In tegenstelling tot de hierboven aangehaalde auteurs hebben Gale en Marsden (1982) well getracht het denken van artsen aan het begin van een consult te beschrijven. $\mathrm{Zij}$ analyseerden 66 echte patiëntcontacten van 22 studenten, 22 arts-assistenten en 22 ervaren artsen. De patiënten presenteerden een grote variëteit aan klachten en ziekten. De proefpersonen kregen onmiddellijk na het consult de video-opnamen daarvan te zien met de bedoeling het denkproces tijdens dat consult te verbaliseren. Deze methode noemt men 'stimulated recall' (Elstein et al, 1978). De onderzoekers waren geïnteresseerd in de aard van de interpretaties die optraden in de eerste 41 tot 49 seconden van het consult. Hierbij onderscheiden ze drie typen interpretaties: prediagnostische, diagnostische of de vaststelling dat men behoefte heeft aan meer informatie van de patiënt. De analyse van de resultaten leverde echter geen verschillen op tussen de groepen. Dit onderzoek richtte zich met name op het soort interpretaties in een informatie-arme situatie maar liet de inhoud van de door de patiënt gepresenteerde klachten en de door de arts gebruikte kennis die daartoe aanleiding geeft buiten beschouwing.

Het in dit proefschrift beschreven onderzoek plaatst de inhoud van klachten en het kennisgebruik juist in het centrum. Door deze nadruk op de inhoud van het denken (de aard van de gebruikte kennis en informatieverwerking) en niet zo zeer op het denkproces sluit het onderzoek volledig aan bij de cognitief-psychologische benadering die het laatste decennium steeds meer gangbaar geworden is. De besliskundige benadering is een andere hoofdstroom in het onderzoek naar diagnostisch denken. In de volgende paragraaf contrasteren we beide benaderingen. 


\section{Twee benaderingen van het onderzoek naar diagnostisch denken.}

Globaal gesproken bestaan er op dit moment twee benaderingen om het diagnostisch denken te onderzoeken: de besliskundige en de cognitief psychologische (Elstein \& Bordage, 1979; Snoek, 1989; Vlek, 1987).

\section{De besliskundige benadering}

Deze aanpak poogt diagnostische en therapeutische afwegingen te beschrijven in termen van logica en statistische theorieèn (zie bijvoorbeeld: Feinstein 1967; Kahnemann, Slovic \& Tversky, 1986; Sacket, Haynes \& Tugwell, 1985; Weinstein \& Fineberg, 1980; Wulff 1980). Voor het merendeel heeft die een normatief karakter. Dat wil zeggen dat (met behulp van mathematische technieken) gestreefd wordt naar het vinden van de optimale oplosstrategieën. In het algemeen tracht de medische besliskunde met kansberekeningen (met name het theorema van Bayes) mentale afwegingen te kwantificeren om zodoende juiste beslissingen te berekenen. Binnen deze benadering probeert men eveneens rekening te houden met maatschappelijke aspecten (kosten-baten analyse), of de beleving en voorkeuren van de patiënt (utiliteiten). Ook bepaald descriptief onderzoek, de 'behavioural decision theory', valt vanwege het sterk mathematische uitgangspunt onder de besliskundige benadering (Einhorn \& Hogarth, 1981; Slovic, Fischhoff \& Lichtenstein, 1977). Laatstgenoemde stroming beschrijft ondermeer hoe (on)logisch en (in)consistent artsen, rechters of andere experts beslissingen nemen ten opzichte van bijvoorbeeld een mathematisch model of computerprogramma (Kahnemann, et al., 1986; Szucko \& Kleinmuntz, 1981; Slovic, et al., 1977; Tversky \& Kahneman, 1983). Het volgende voorbeeld illustreert een typische benadering uit deze stroming. Leaper en medewerkers (Leaper, Horrocks, Staniland, \& De dombal, 1972) onderzochten de accuraatheid van kansschattingen door clinici. Men vergeleek diagnosen gesteld door een op het theorema van Bayes gebaseerd computermodel met de feitelijke diagnose bij een groot aantal patiënten met acute buikpijn. Zij vonden dat de diagnostisch accuraatheid van de computer minder was wanneer het model 'gevoed' werd met de kansschattingen van clinici vergeleken met 'voeding' door ziektekansen gebaseerd op epidemiologische gegevens. Zij concludeerden hieruit dat schattingen van artsen over ziektekansen bij patiënten niet accuraat genoeg zijn om (vergeleken met 'real life data') met behulp van baysiaanse modellen te gebruiken in een besliskundige analyse van een medisch probleem.

Nederlands huisartsgeneeskundig onderzoek draagt sterk de sporen van de besliskundige benadering. Voorbeelden hiervan zijn veelal te vinden in de projecten die uitgevoerd worden onder de paraplu van de NWO Werkgemeenschap Huisartsgeneeskunde. Ook het invoeren van standaarden voor huisartsgeneeskundig handelen is mede ingegeven door de gedachte dat het gedrag van huisartsen te normeren is aan de hand van logische beslissingen op basis van beschikbare (meestal epidemiologische) kennis.

Aan deze benadering kleeft een aantal nadelen. Gebrek aan gegevens (bijvoorbeeld met betrekking tot a priori kansen van ziekten in een huisartspopulatie) maakt de besliskundige benadering vooralsnog ongeschikt om een bijdrage te leveren aan het verbeteren van de diagnostiek in de allereerste fase van een consult (Knottnerus, 
1987). Daarnaast kan men zich afvragen of niet eerst meer bekend moet zijn omtrent het feitelijke denken bij huisartsen. Wanneer daarover meer bekend is, kunnen de protocolaire richtlijnen beter aansluiten op het feitelijk handelen van huisartsen. Dat zou de kans op acceptatie en implementatie van protocollen groter kunnen maken.

\section{De cognitief psychologische benadering}

Deze benadering is primair gericht op het beschrijven van het (medisch) denken in termen van een informatieverwerkend systeem. Globaal verloopt de humane informatieverwerking als volgt: informatie uit onze omgeving bereikt via de zintuigen het korte termijn geheugen. Dat geeft aan deze informatie betekenis door de kennis die geactiveerd wordt uit het lange termijn geheugen. Niet alleen wordt kennis toegevoegd aan die informatie, ook vindt, wederom onder invloed van de aanwezige kennis in het lange termijn geheugen, een selectie plaats tussen belangrijke en onbelangrijke zaken. Dit samenhangend geheel van bewerkte informatie wordt de 'interne representatie' genoemd. Wanneer de representatie ontstaat in de context van het oplossen van een probleem wordt hij ook wel 'probleemrepresentatie' genoemd. De interne representatie verandert continue onder invloed van nieuwe binnenkomende informatie of verdere activatie van kennisbestanddelen uit het geheugen. De kwaliteit van de uiteindelijk representatie wordt enerzijds bepaald door de samenhang van de aangeboden informatie (Bransford \& Johnson, 1972), anderzijds door de bij die persoon aanwezige domeinspecifieke kennis. Deze kennis betreft zowel de situatie waarin (Bower, Monteiro \& Milligan, 1978; Godden \& Baddeley, 1975) alswel de manier waarop zij is opgeslagen (Bransford, Sherwood, Vye \& Rieser, 1986; Leinhardt, 1987; Perfetto, Bransford \& Franks, 1983).

Het model van informatieverwerking is toepasbaar op zeer uiteenlopende mentale processen, van het praten met een familielid aan de telefoon tot en met het voeren van een medisch consult. Het volgende voorbeeld laat zien hoe in de cognitief psychologische traditie onderzoek gedaan wordt, in dit geval naar het zogenaamde 'intermediate effect' in het uit het geheugen reproduceren van een klinische casus (Schmidt, Boshuizen \& Hobus, 1988). In het onderzoek naar de medische probleemrepresentatie bij studenten en ervaren artsen observeert men vaak het zogenaamde 'intermediate effect'. Dit fenomeen houdt het volgende in: wanneer studenten en ervaren artsen na afloop van het oplossen van een papieren casus gevraagd wordt zoveel mogelijk informatie van de casus in herinnering te roepen (de zogenaamde 'recall'), blijken de beginnende studenten én ervaren artsen minder van de casus te onthouden dan studenten die reeds het grootste gedeelte van hun theoretische vorming erop hebben zitten (ongeveer 4de-jaars stuenten in het Nederlandse curriculum). Men zou op grond van de verwachting dat ervaren artsen een betere verwerking van patiënt informatie hebben en daardoor een beter gestructureerde probleemrepresentatie opbouwen, kunnen veronderstellen dat zij beter in staat zijn om de verwerkte informatie te reproduceren dan medische studentenen met minder ervaring. De oorzaak voor dit onverwachte, omgekeerd U-vormig verband tussen recall en expertise is door de bovengenoemde auteurs nader onderzocht. Honderdtwintig proefpersonen van vijf verschillende ervaringsniveaus (variërend 
van medische leken tot en met ervaren internisten) werd gevraagd eenzelfde casus betreffende een patiënt met acute bacteriële endocarditis op te lossen. In dit onderzoek hanteerden de auteurs een drietal toegestane bestuderingstijden. Een lange bestuderingstijd van 3 minuten en 30 seconden; deze kwam overeen met die in een eerder experiment van Patel en Groen (1986). Een bestuderingstijd van 1'15 seconden overeenkomend met de gemiddelde bestuderingstijd van een aantal ervaren cardiologen om tot een eerste diagnostische hypothese te komen, en tot slot een zeer korte bestuderingstijd van slechts 30 seconden: net genoeg om de aangeboden tekst vluchtig te 'scannen'. Uit de resultaten bleek dat het intermediate effect in de recall van de casusinformatie verdween door de bestuderingstijd te beperken. Of in andere bewoordingen: de ervaren internisten bleken ongevoelig voor de beperkingen die door de korte bestuderingstijd werden opgelegd terwijl de 4de jaars studenten hierdoor wel significant minder casus informatie onthielden. De auteurs verklaren de invloed van de bestuderingstijd op het intermediate effect als volgt. Wanneer medische studenten voldoende tijd gegund is om een casus te bestuderen wordt de aangeboden patiënt-informatie uitgebreid verwerkt met behulp van pathofysiologische kennis; is de tijd echter beperkt, dan zal door de tijdsdruk de probleemrepresentatie onvolledig en inaccuraat zijn en dientengevolge de recall daarvan minder uitgebreid. Bij ervaren internisten echter vindt, onafhankelijk van de gegunde bestuderingstijd, een veel snellere en oppervlakkiger verwerking met behulp van patroonherkenning plaats, waarbij bewust redeneren met pathofysiologische kennis nauwelijks nodig is.

Het onderzoek, dat in dit proefschrift gepresenteerd wordt, neemt het informatieverwerkingsmodel en de cognitief psychologische benadering als uitgangspunt. Wat nu volgt is een nadere beschrijving vanuit dit cognitief perspectief van de ontwikkelingen die in de theorievorming omtrent medische expertise hebben plaatsgevonden.

\section{Cognitief-psychologische theorievorming op het gebied van medisch probleemoplossen}

Het onderzoek naar probleemoplossen (waaronder ook het onderzoek naar medisch probleemoplossen) is vanaf 1960 enkele decennia lang sterk beïnvloed door het werk van Newell en Simon (Newell, Shaw \& Simon, 1959; Newell, \& Simon, 1972). Deze onderzoekers gingen uit van de veronderstelling dat het ontwikkelen van vaardigheden op een bepaald terrein het gevolg is van het verwerven van een groot repertoire aan oplosstrategieën. Daardoor lag de nadruk in het onderzoek niet zozeer op de inhoud van het denken, maar keek men meer naar de wegen waarlangs de verschiliende denkstappen verlopen. Door op deze manier het denkproces van bijvoorbeeld goede of ervaren artsen te analyseren, dacht men probleemoplosmethoden te kunnen ontdekken die kenmerkend zijn voor de goede of ervaren arts. Ook dacht men deze oplosmethoden door middel van training als onafhankelijke entiteit te kunnen overdragen aan minder goede of nog onervaren artsen om zo hun diagnostische kwaliteit te verbeteren. 
Veel van het onderzoek naar medisch probleemoplossen in de jaren '60 en '70 was dan ook vooral gericht op het beschrijven van het: proce's van informatieverwerking (Barrows, et al. 1978; Elstein, et al. 1978; Gerritsma \& Smal, 1982; Gale \& Marsden, 1984; Kassirer \& Gorry, 1978; Wortman, 1966). Dit uitte zich vooral in de keuze van de te onderzoeken variabelen zoals bijvoorbeeld de snelheid waarmee hypothesen tot stand komen of het aantal gegenereerde hypothesen of diagnostische vragen op het moment van hypothesevorining, het aantal routine versus nietroutine vragen, gehanteerde strategieën en heuristieken. De inmiddels klassiek geworden studies van Elstein (Elstein, et al. 1978) en Barrows (Barrows, et al. 1978) bestudeerden eveneens voornamelijk procesvariabelen zoals het aantal geformuleerde hypothesen (totaal of op een bepaald moment gedurende het diagnostisch proces), het aantal routinematig gestelde versus het aantal van hypothesen afgeleide vragen, het percentage door de arts verzamelde relevante patiëntgegevens (beoordeeld door een panel van deskundigen), etc. Echter in al deze onderzoeken werden met betrekking tot deze variabelen nauwelijks verschillen gevonden tussen ervaren en onervaren diagnostici.

Niet alleen deze studies, maar ook al de andere onderzoeken die zich richtten op het proces van medisch probleemoplossen, faalden in het naar voren brengen van specifieke oplosstrategieën die eigen zij̣n aan de expert. Wel kwam een ander belangrijk gegeven naar voren, namelijk het feit dat de kwaliteit van hypothesevorming en uiteindelijk ook de kwaliteit van de diagnose en therapie toenam naarmate de diagnostische ervaring van de proefpersoon toenam. Barrows et al. (1978) formuleerde dit als volgt: "In our examination of the problem-solving process of students and clinicians in previous chapters, the formation of diagnostic hypotheses early in the encounter has been shown to occupy a central role. The first hypothesis is generated within a few seconds of the chief complaint, and about half the questions asked are directly related to one or more of the five to six hypotheses generated over the course of the encounter. The content of these hypotheses, (.....), is the major predictor of diagnostic and management outcomes, and is strongly related to the educational level. In physicians, earliness of generating the first and the correct hypothesis are similarly correlated with outcomes (p. 160)."

De aanvankelijke veronderstelling dat de uitkomst van het diagnostisch denkproces ondermeer afhankelijk zou zijn van een bepaalde algemene 'vaardigheid om medische problernen op te lossen' werd dus niet bevestigd. In latere jaren veranderde de aandacht in het onderzoek van het proces van probleemoplossen naar de inhoud en de roi van de aanwezige keinnis. Immers wanneer geen verschillen kunnen worden aangetoond tussen goede en minder goede artsen of tussen ervaren en onervaren artsen met betrekking tot het proces van probleennoplossen, dan moet het verschil in kwaliteit van probleemoplossen wel gezzocht worden in de verschillen in kennis en de veranderingen die daarin plaatsvinden onder invloed van ervaring. In meer recente opvattingen over medisch probleemoplossen ligt de nadrulk daarom veel meer op kenmerken van de kennis. Het inzicht dat domeinspecifieke: kennis een bepalende factor is tijdens het oplossen van problemen, is inmiddels ook tot rijping gekomen op vele andere onderzoeksterreinen van de cognitieve psychologie (Bransford, et al. 1986; Glaser, 1984). Daarom gaan we op de rol van kennis in de vol- 
gende paragrafen nader in. Voor een meer uitgebreide historie van deze vieranderde inzichten in medisch probleemoplossen verwijzen. we naar de proefschuriften van Boshuizen (1989), Snoek (1989), en Ronteltap (1990).

\section{De rol van kennis}

Een klassiek voorbeeld van de rol van kennis bij menselijk cognitieve prestaties is beschreven door Ericsson (Ericsson, Chase \& Faloon, 1980). Deze onderzoekers hebben gedurende anderhalf jaar een middelbare schoolleerling met gemididelde intelligentie en geheugencapaciteit getraind in het onthouden van random getallen. Wekelijks presenteerden de onderzoekers hem gedurende een sessie van ongeveer een uur getallen van een bepaalde lengte. Als hij in staat bleek het getal correct te onthouden, werd het volgende getal, dat hem werd gepresenteerd, met een ciffer verlengd. Wanneer de recall daarvan niet correct was, wrercl het volgende getal. met een cijfer verkort. Normaal heeft de mens moeite getallen groter dan 7 cijfers te onthouden (dit wordt de 'digit span' genoemd). Toch bleek deze proefpersoon na anderhalf jaar oefenen in staat om random getallen van bijna 80 cijfers te onthouden! (zie figuur 1.1).

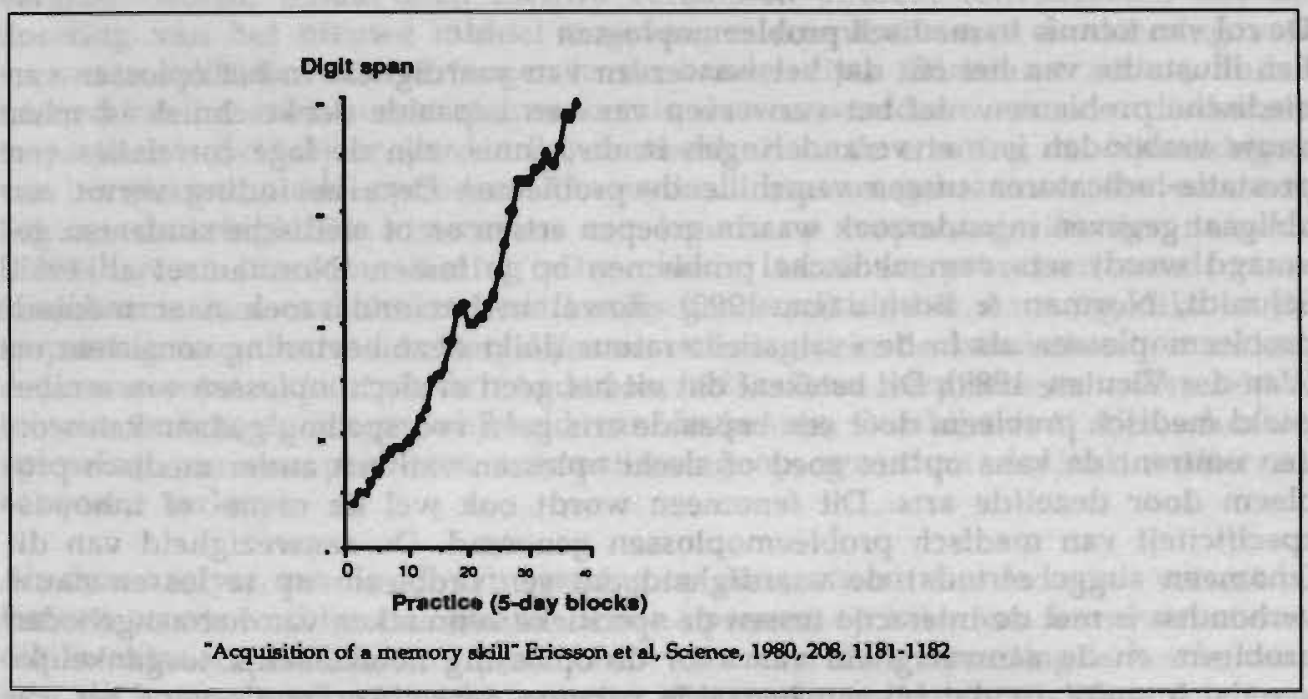

Figuur 1.1: Effect van training op een geheugentaak

De figuur 1.1 laat de groei van zijn vaardigheid zien om random getallen te onthouden en later weer in herinnering te brengen. Na 50 trainingsdagen was de gemiddelde lengte van de correct onthouden getallen verdubbeld, en na 100 trainingsdagen reeds bijna verzevenvoudigd. $\mathrm{Na} 200$ trainingsclagen onthield de proefpersoon getallen van meer dan tienmaial de normale lengte van zeven cijfers. De reden waarom de proefpersoon tot deze prestatie kwam, bleek gelegen te zịn in zijn uitgebreide kennis van tijden die hardlopers in bepaalde wedstrijden gelopen 
hebben. Door de aangeboden random getallen te vertalen in combinaties van wedstrijdtijden, leeftijden van hardlopers en andere data omtrent zijn favoriete sport, bleek hij in staat betekenis te geven aan op zichzèlf betekenisloze getallen. Deze geheugenvaardigheid is dus een uiting van toenemend gebruik van vooraf aanwezige domeinspecifieke kennis (in dit geval kennis over hardlopers) en niet van een groter wordend korte termijn geheugen. Door training werd deze aanwezige kennis over hardlopers meer en meer ingezet voor deze geheugentaak.

Hoewel het hier een niet alledaagse vaardigheid betreft, illustreert dit voorbeeld goed hoe de prestatie op een bepaalde taak afhankelijk is van de aanwezigheid van toepasbare kennis en verder dat kennis meer toepasbaar wordt onder invloed van intensief gebruik. Dergelijke bevindingen komen herhaaldelijk naar voren in onderzoek naar leren en probleemoplossen in het algemeen. Maar zoals we al zagen, ook op een specifiek terrein als dat van de geneeskunde lijkt een strikte scheiding tussen (ervarings)kennis enerzijds en probleemoplossen anderzijds niet te bestaan. Uit de opbrengsten van het onderzoek naar medisch probleemoplossen in de jaren zeventig komen nog meer zaken naar voren waaruit blijkt dat deze scheiding feitelijk kunstmatig en misleidend is.

\section{De rol van kennis in medisch probleemoplossen}

Een illustratie van het feit dat het verwerven van vaardigheid in het oplossen van medische problemen niet het verwerven van een bepaalde denktechniek is, maar nauw verbonden is met veranderingen in de kennis, zijn de lage correlaties van prestatie-indicatoren tussen verschillende problemen Deze bevinding vormt een obligaat gegeven in onderzoek waarin groepen artsen en of medische studenten gevraagd wordt sets van medische problemen op te lossen (Norman, et al. 1985; Schmidt, Norman \& Boshuizen, 1990). Zowel in het onderzoek naar medisch probleemoplossen als in de evaluatieliteratuur duikt deze bevinding consistent op (Van der Vleuten, 1989). Dit betekent dat uit het goed of slecht oplossen van een bepaald medisch probleem door een bepaalde arts geen voorspelling gedaan kan worden omtrent de kans op het goed of slecht oplossen van een ander medisch probleem door dezelfde arts. Dit fenomeen wordt ook wel de casus- of inhoudsspecificiteit van medisch probleemoplossen genoemd. De aanwezigheid van dit fenomeen suggereert dat de vaardigheid om een probleem op te lossen nauw verbonden is met: de interactie tussen de specifieke kenmerken van het aangeboden probleem en de aanwezigheid van voor de oplossing noodzakelijk toegankelijke kennis. Immers, omdat bij een bepaalde persoon dergelijke kennis voor het ene probleem beter georganiseerd is dan yoor het andere zal de kwaliteit van de oplossing daaraan onderhevig zijn. Oplosstrategieën variëren daardoor enerzijds met de aard van het medisch probleem (vaag versus specifiek, internistisch of dermatologisch) anderzijds met de aanwezigheid en toegankelijkheid van kennis. Ook hier weer blijken oplosstrategieën feitelijk geen onafhankelijke entiteit die een bepaalde arts bezit, maar een uiting van de dynamiek van de interne probleemrepresentatie. Anders gezegd: oplosvaardigheden zijn geen abstracte en consistente trek van de arts, maar een direct waarneembare uiting vain de interactie tussen aangeboden informatie en door de arts toegepaste kennis. 
Kennis vormt dus de basis voor de expertise van ervaren artsen. Maar de toenemende toegankelijkheid van deze kennis onder invloed van praktijkervaring is misschien nog belangrijker. Want, bepaalde medische kennis zal door het dagelijks gebruik in vele patiëntcontacten meer paraat zijn dan kennis die slechts incidenteel gebruikt wordt. Zo kan de huisarts bepaalde receptuur zonder veel nadenken uit de pen laten vloeien, terwijl hij andere receptuur nog even moett 'checken' in het geneesmiddelenrepertorium. Dit proces van veranderingen in de kennisstructuur kan leiden tot automatismen waardoor met zeer weinig mentale inspanning een koppeling plaatsvindt tussen de aangeboden informatie en een bepaalde handeling, bijvoorbeeld reflexreceptuur zoals 'Griep' $\rightarrow>$ 'Paracetamol'.

Om dergelijke veranderingen in de kennisstructuur te beschrijven hanteert de cognitieve psychologie een aantal begrippen. Dit zijn ondermeer 'accretion', 'restructuring', en 'tuning' van kennis (Rumelhart \& Norman, 1978). De eerste ('accretion') is het toevoegen van nieuwe feitenkennis aan een bestaand bestand (bijvoorbeeld het opzoeken van de precieze sterkte van een nieuw middel dat je wilt voorschrijven). 'Restructuring' of herstructurering van kennis gebeurt onder invloed van het werken met deze nieuwe feiten, waardoor het begrip ervan vergroot wordt, omdat men nieuwe verbanden ontdekt (bijvoorbeeld dat de dosering van het nieuwe middel ongeveer overeenkomt met de dosering van verwante middelen die al langer in de handel zijn). Daarnaast zullen, onder invloed van het werken met nieuwe kennis, de voorwaarden waaronder die kennis toepasbaar is duidelijker worden (bijvoorbeeld zal na de ervaring dat bijwerkingen van het nieuwe middel optreden bij bejaarden adequater gekozen worden voor een lichtere dosering). Dit afstemmen van kennis op toepassingssituaties noemen Rumelhart en Norman 'tuning'. Door beide laatste leerprocessen wordt pure feitenkennis (ook wel declaratieve kennis genoemd) als het ware ingedikt en de toepassing ervan versneld. Dergelijke veranderingen in de kennisstructuur noemt Anderson ook wel 'compilatie' (Anderson, 1983). Deze leerprocessen zullen leiden tot een verhoogde toegankelijkheid van de kennis. Daarbij treedt bij herhaalde oplossing van een probleem automatisering op, waardoor de taak sneller en adequater verloopt.

Als deze analyse van de rol van ervaring op de structuur van de kennis correct is, kunnen we verwachten dat ervaren artsen opereren op basis van kennisstructuren die kwalitatief verschillen van onervaren artsen. In deze opvatting is het immers juist de hoeveelheid praktische ervaring die ervoor verantwoordelijk is (via herstructurering en tuning) dat de kennis van ziekte en determinanten zich steeds beter aanpast aan de uitdagingen waarvoor de arts elke dag staat. De vraag is dan natuurlijk wat de precieze aard van de kennis is en welke veranderingen die ondergaat als gevolg van ervaring. Om die vraag (althans tentatief) te beantwoorden, zullen we in de volgende paragraaf een theorie bespreken die beschrijft hoe medische kennis onder invloed van leren en ervaring ervaring verandert. Die bespreking stelt ons in staat meer precies de vraagstelling van de in dit proefschrift te presenteren studies te definiëren. 
Veranderingen in de medische kennis: van pathofysiologie tot ziekte-script

Schmidt en Boshuizen (1992) suggereren dat de ontwikkeling van expertise in de geneeskunde verloopt volgens een aantal stadia, die zich kenmerken door het verwerven van kwalitatief verschillende kennis. Overgangen van het ene stadium naar het andere verlopen niet geleidelijk maar betrekkelijk schoksgewijs als gevolg van blootstelling aan nieuwe leerervaringen. Met name wanneer pas afgestudeerde artsen uitgebreider in contact komen met patiënten ontstaat door reorganisatie van al aanwezige kennis en integratie van de praktische ervaringen die dan dagelijks worden opgedaan, een nieuw soort kennis van een geheel andere structuur.

Volgens deze auteurs verloopt de ontwikkeling en opbouw van kennis als volgt: In de aanvang van de studie verwerft een student geneeskunde uitgebreide feitenkennis over de basale medische vakken zoals anatomie, biochemie, microbiologie en (patho-)fysiologie. Door deze kennis gedurende de studie vaak en herhaald toe te passen, ontstaan causale netwerken die als verklaringsmodel dienen voor ziekten en symptomen bij de mens. Deze netwerken bevatten voornamelijk declaratieve kennis die door 'restructuring' en 'tuning' steeds meer verdichten en beter toepasbaar worden tijdens het oplossen van diagnostische problemen. Tegelijkertijd ontstaan nieuwe configuraties van concepten, typisch van klinische aard, waarin gedetailleerde kennis als het ware 'ingekapseld' wordt. Schmidt en Boshuizen omschrijven dit proces als inkapseling van pathofysiologische kennis of 'encapsulation'. De resulterende set van hogere-orde concepten is zeer makkelijk toegankelijk. Encapsulatie van pathofysiologische kennis stelt de arts in staat complexe problemen met behulp van enkele constructen te begrijpen en te karakteriseren.

Een voorbeeld: wanneer gedurende het oplossen van een medisch probleem activatie van de kennis omtrent ontstekingsreacties plaatsvindt, zal als gevolg van encapsulatie niet meer alle hierover verworven kennis in de probleemrepresentatie geactiveerd worden, doch slechts een model. Zo zal niet ál de kennis met betrekking tot weefselbeschadiging, bacteriën, virussen, trauma's, de reacties van leucocyten, lymfocyten en macrofagen, directe en indirecte gevolgen van weefselinfiltratie en ontstekingsmediatoren, lokale en systemische effecten, etc. geactiveerd worden, doch slechts een simpel klinisch direct relevant model zoals: 'een ontstekingsreactie is weefselbeschadiging door een bepaalde prikkel die kan leiden tot koorts en lokale: effecten zoals roodheid, zwelling en verminderde functie.' Tegen de tijd dat studenten en artsen meer en meer in contact komen met patiënten vormt zich zo als het ware een nieuwe 'kennislaag'. ' Niet langer wordt deze ervaringskennis in reeds bestaande causale netwerken opgeslagen, maar ze neemt de vorm aan van zogenaamde ziekte scripts ('illness-scripts'). In dergelijke ziekte scripts zit de voorheen opgedane, basaal medische kennis in geëncapsuleerde vorm verweven.

\footnotetext{
${ }^{1}$ Een van de bijzondere kenmerken van de theorie van Schmidt en Boshuizen is dat zij veronderstellen dat de nieuw ontstane, meer op de behoeften van de praktijk toegesneden, kennisstructuren de oude structuren niet vervangen maar "sedimenteren" op die oude structuren. Dat zou o.a. verklaren waarom ervaren artsen, wanneer ze een probleem niet meteen kunnen oplossen, terugvallen op een meer pathofysiologische manier van redeneren.
} 
Het idee van illness scripts als cognitieve structuren op grond waarvan artsen opereren, werd gepostuleerd door Feltovich en Barrows (1984). Zij veronderstellen dat gedurende een consult een mentale representatie van het probleem wordt opgebouwd welke in zijn globale vorm, onafhankelijk van de specifieke klacht of de ervaring van de arts, telkens dezelfde structuur heeft. Een illness-script beschrijft hoe iemand een ziekte oploopt, wat daarin de belangrijkste verstoring op pathofysiologisch niveau is, en wat dáárvan weer de gevolgen zijn. Een dergelijke script bestaat dus uit drie compartimenten die deels associatief en deels causaal met elkaar verbonden zijn. Figuur 1.2 bevat de algemene vorm die een ziekte-script volgens Feltovich en Barrows (1984) aanneemt.

\section{Ziekte script}

Enabling Conditions: Factoren die al of niet causaal geassocieerd zijn met het ontstaan van een verstoring ergens in het lichaam

Fault: Pathofysiologische verstoring kenmerkend voor een bepaalde ziekte(klasse)

Consequences: Symptomen: anamnestische, lichamelijke, biochemische, of röntgenologische afwijkingen.

Figuur 1.2: ziekte script (Feltovich \& Barrows)

Het eerste compartiment bestaat uit de representatie van factoren die geassocieerd zijn met het krijgen van een ziekte. Zij worden 'Enabling Conditions' genoemd. Hierbij denkt men aan risiciofactoren zoals roken, overmatig alcoholgebruik, bepaalde beroepen of medicijnen, maar ook aan prediposities door leeftijd, geslacht, familiaire belasting, sociale of psychische achtergronden en het hebben van chronische (recidiverende) aandoeningen. Dergelijke factoren bevorderen het ontstaan van een verstoring in het menselijk lichaam, of maken een dergelijke verstoring mogelijk ('enabling'). Het compartiment dat de representatie van de verstoring vormt, wordt omschreven met de term 'Fault'. Voorbeelden hiervan zijn: acute ischemie van het myocard door trombotische processen in een coronair arterie bij preëxistente atherosclerosis, of in het geval van astma: acute bronchospasmen ten gevolge van onstekingsreacties bij het inhaleren van allergenen. Een simpeler voorbeeld is de aanwezigheid van een steentje in de ureter bij nierkolieken, of verscheurde weefselstrukturen bij een enkeldistorsie. De fault leidt tot bepaalde uitingen die waarneembaar zijn of anamnestisch achterhaalbaar. Kortom symptomen zoals pijn op de borst, transpireren, angst, of afwijkingen op een ECG. Dit zijn de 'Consequences' in het ziekte script. In figuur 1.3 is een voorbeeld van een ziekte script voor het myocard infarct opgenomen.

Volgens Feltovich en Barrows zou tijdens de constructie van ziekte scripts gebruik worden gemaakt van de kennis van medische basisvakken zoals anatomie, pathofysiologie, epidemiologie, of farmacologie. Dergelijke kennis bepaalt hoe de informatie in de diverse script compartimenten aan elkaar gerelateerd is. Die vormt als het 
ware de onderliggende structuur van het script. Een voorbeeld daarvan is de kennis omtrent anaerobe stofwisseling, weefselgeleiding en de electrocardiografie welke noodzakelijk is om te begrijpen hoe tijdens een infarct door de afsluiting van de bloedstroom in een coronairvat (de 'fault') bepaalde veranderingen van het electrocardiogram op gaan treden (de 'consequences').

\section{Myocard infarct}

Enabling_Conditions: Mannelijk geslacht, gevorderde leeftijd, roken, hypertensie, belaste familieanamnese etc.

Fault: Acuut verminderde doorbloeding en oxygenisatie van het myocard.

Consequences: Angineuze pijn op de borst, langer dan 30 minuten, uitstraling naar kaken en /of arm, shock, ritmestoornissen, decompensatio cordis, etc.

Figuur 1.3: voorbeeld van ingevuld ziekte script.

De mentale opbouw en afwikkeling van een ziekte script zou volgens Feltovich en Barrows als verschijnsel belangrijker zijn dan het genereren van hypothesen en het testen daarvan. Beide laatste volgen als het ware vanzelf uit de toestand van de in ontwikkeling zijnde scripts. Zo zal in het geval van een oudere man die rookt (enabling conditions) met pijn op de borst (consequence) gedacht kunnen worden aan cardiale ischemie of pleurale prikkeling (fault). Dergelijke incomplete scripts zouden gelabeld kunnen worden met de hypothesen 'hartinfarct' of 'pneumonie'. De arts zou kunnen vragen naar koorts en opgeven van groen sputum om het pneumonie script te completeren. Daarmee wordt de hypothese pneumonie bevestigd of verworpen. (Zulke vragen zijn dus een gevolg van nog oningevulde consequences in het pneumonie script en dus niet het gevolg van een algemene probleemoplossingsstrategie.). Worden deze vragen ontkennend beantwoord dan zal het hartinfarct script meer op de voorgrond treden en dientengevolge leiden tot vragen die trachten dit script te consolideren.

Voor Feltovich en Barrows (1984) is een illness script het resultaat van een poging een probleem te representeren; de onderliggende kennisstructuren zijn in hun visie pathofysiologisch van aard. Zoals gezegd betwiifelen Schmidt en Boshuizen of kennis uit de medische basisvakken gedurende de afwikkeling van een script wel zo intensief gebruikt wordt. Voor hen is het illness script niet zozeer de resulterende representatie van het probleem van een patiënt, maar juist een deel van het bestaande kenrisbestand dat gebruikt wordt om het probleem te internaliseren. De geslaagde probleemrepresentatie bestaat in hun visie uit een 'geïnstantieerd' script. Niettemin wijzen ook deze laatste auteurs op de aanwezigheid van (patho)fysiologische kennis in een script, zij het in de vorm van 'encapsulated knowledge'. 
Het idee van ziekte scripts biedt een eenvoudig en goed model om de allereerste fase van het diagnostische proces bij huisartsen te onderzoeken. Het: speelt derhalve in de onderhavige studies een centrale rol. De notie van ziekte scripts en hun activatie en instantiatie tijdens het diagnostische proces nnaakt het mogelijk om de algemene vraag in dit proefschrift (namelijk die factoren onderzoeken die het ontstaan van voorlopige diagnostische hypothesen beïnvloeden) in deze termen te herformuleren. Dat wil onder andere zeggen dat we moeten achterhalen hoe ziekte scripts zijn gestructureerd en hoe ze geactiveerd worden. Vanzelfsprekend moeten we een deel van de verklaring zoeken in de informatiezijde van het consult. Willen we immers begrijpen waarom ervaren artsen betere ziekte scripts activeren dan bij relatief onervaren artsen, dan moeten we goed op de hoogte zijn van de informatie die ons op dat moment ter beschikking staat.

\section{Kenmerken van de informatie in de beginfase van het consult}

Welke informatie heeft de huisarts voorhanden op het moment dat zijn patiënt een klacht presenteert? Een nadere beschouwing leert dat op dat moment veel meer informatie voorhanden is dan alleen de klacht zoals de patiënt die vocaliseert. Het meest direct beschikbaar is nonverbale informatie, die wordt overgedragen bij binnenkomst in de spreekkamer, zoals een bepaalde gelaatsuitdrukking, een wijze van bewegen, of leeftijd en geslacht. Een andere bron van informatie is de voorgeschiedenis en achtergrondkenmerken van de patient die zijn opgeslagen in het geheugen van de huisarts en genoteerd op de groene kaart. Het betreft onder andere het beroep, risicogedrag, familiair voorkomende aandoeningen, eerdere ziekten, sociale en psychische gesteldheid en niet te vergeten het medicijngebruik. Al deze, impliciet in de situatie van de klacht-presentatie voorkomende, informatie noennen we hier 'contextuele informatie'.

Men kan zich voorstellen dat naast de klacht ook contextuele informatie een belangrijke rol speelt in vroege hypothesevorming. In het onderzoek dat we in de volgende hoofdstukken presenteren, speelt deze gedachte een centrale rol. In de gedachtenstroom van de huisarts die aan het begin van dit hoofdstuk gepresenteerd werd, komt het gebruik van contextuele informatie vaak naar voren. Zo verwacht de huisarts dat het bezoek van patiëntje B wel weer verband zal houden met zijn chronische luchtwegproblematiek. (Die verwachting blijkt juist: het patiëntje blijkt inderdaad weer een toename van benauwdheid te hebben.) Bij patiërite $C$ koestert de huisarts de hoop dat na behandeling van haar diabetes een verbetering van de toestand van haar ontstoken teen is opgetreden. Patiënt I heeft drie maanden gesukkeld met een salmonella dragerschap en de huisarts verwacht meteen bij zijn binnenkomst dat deze man buikklachten gaat presenteren. Dergelijke verwachtingen worden uiteraard niet altijd bevestigd. Een voorbeeld is patiënte $K$ waarvan de arts verwacht dat deze voor orale anticonceptiva komt ondat zij onlangs bevallen is. De patiënt blijkt echter een sinusitis te hebben. Toch brengt de huisarts ook deze aandoening in verband met het contextuele gegeven van de recente partus, namelijk via het idee van de verrninderde weerstand. Bij patiënten $O$ en $R$ speelt de achtergrondinformatie zeker een essentiële rol. Immers beide 
patiënten staan te boek in de categorie 'geen zeurpieten'. Patiënt $O$ komt altijd voor zijn vrouw op het spreekuur en patiënt $\mathrm{R}$ komt alleen wanneer hij 'echt ziek' is. De huisarts is daarom extra alert op het vinden van een somatische afwijking. Patiënt $O$ blijkt dan ook gonartrosis en een cystitis/prostatitis te hebben. Patiënt $R$ heeft vermoedelijk een maligniteit. Daartegenover wordt het warrige verhaal van patiënte $G$ met een trauma aan het onderbeen voorlopig als niet belangrijk beschouwd, omdat zij bekend staat als een nerveuze persoon. Ook al is de huisarts nog niet zolang bekend met de voorgeschiedenis van een patiënt, zijn verwachtingen omtrent de 'reasons for encounter' worden desalniettemin wezenlijk beïnvloed door zelfs zeer beperkte voorafgaande ervaringen met de betreffende patiënt. Een voorbeeld hiervan is patiënte $Q$ die met haar grote hoeveelheid klachten en haar nog jeugdige leeftijd niet meteen in de categorie ernstige aandoeningen geplaatst wordt.

\section{Vraagstelling}

Bovenstaande voorbeelden laten duidelijk zien dat contextuele informatie een 'bron' is voor enabling conditions. Met andere woorden: zodra contextuele gegevens geïnterpreteerd worden als zijnde gerelateerd aan het gegeven klacht, dan is die informatie gecategoriseerd als een of meerdere enabling conditions. Welke specifieke ziekte scripts en diagnosen in het geheugen geactiveerd worden, zouden de daaraan verbonden enabling conditions weleens kunnen bepalen. Kennis van verschillende enabling conditions geeft een klacht specifieke betekenis en kan het zoekproces in het geheugen verkorten. Op die manier worden snel één of enkele relevante ziekte scripts met daaraan gekoppelde diagnostische hypothesen geactiveerd van waaruit het verdere diagnostische proces gestalte krijgt ${ }^{1}$. Het adequaat oplossen van een medisch probleem is dan ondermeer afhankelijk van de vraag in hoeverre de toegepaste kennis sensitief is voor de aanwezige enabling conditions in de context van de klacht.

Een belangrijk element van dat diagnostisch proces is de kwaliteit van de vroege hypothesen. In de aanvang van dit hoofdstuk zagen we immers dat ervaren (huis)artsen tot kwalitatief betere diagnosen en therapiekeuzen komen dan onervaren artsen, omdat ze reeds in de aanvang van het consult betere (diagnostische) hypothesen vormen. Het onderzoek dat we in dit proefschrift presenteren, concentreert zich op de vraag waardoor dit kwalitatief verschil ontstaat. Volgens de beschreven cognitieve theorieën moet het al vroeg in een consult genereren van correcte hypothesen door ervaren artsen het resultaat zijn van effectief informatie-

\footnotetext{
${ }^{1}$ Deze veronderstelling is niet zo vanzelfsprekend als ze wellicht lijkt. Andere auteurs, met name uit het gebied van de Al en de medische expert systemen, brengen andere ideeën hierover te berde. Kassirer, et al (Kassirer, Kuipers \& Gorry, 1982) nemen aan dat hun illness frames (een aan de ziekte scripts verwante vorm van representatie) slechts door bepaalde activatie-links kunnen worden geactiveerd. Die activatie-links zijn bijvoorbeeld de aard en lokatie van de pijn, of een pathognomisch verschijnsel. Context gegevens kunnen een dergelijke rol niet spelen. In MYCIN hebben context gegevens een rol in het verificatie- en falsificatieproces van aktieve hypothesen (Clancey, 1983). Ook hier worden ze niet gebruikt bij de activatie ervan.
} 
gebruik onder invloed van de aanwezigheid van adekwate kennis, en is zij niet noodgedwongen het resultaat van een bewust gevolgde strategie.

Inmiddels kwam in aan de orde hoe de kennis die tijdens de studie geneeskunde is opgedaan in causale netwerken in het geheugen wordt opgeslagen en later verandert onder invloed van dagelijkse ervaringen met patienten. De ziekte scripts die hierbij tot ontwikkeling komen, vormen de meest essentiële kennislaag waarvan de arts tijdens het diagnostisch proces gebruikt maakt. Hoe de struktuur en kenmerken van ziekte scripts zelf veranderen onder invloed van jarenlange praktijkervaring is niet bekend.

Toch ligt hierin mogelijkerwijs wel een deel van de verklaring voor de verschillen in diagnostische prestaties tussen ervaren en onervaren artsen. Met name de constatering dat de aanwezige informatie in het begin van het consult (contextuele informatie) een bron voor enabling conditions kan zijn, én de activerende rol die deze informatie bij het zoeken naar relevante kennis in het geheugen kan spelen werpen een aantal vragen op.

Ten eerste de vraag in hoeverre ervaren huisartsen en 'onervaren' artsen verschillen in het gebruik van contextuele informatie, met daaraan gekoppeld de vraag: ligt een eventueel gevonden verschil ten grondslag aan de betere diagnostische beginhypothesen van ervaren huisartsen?

Ten tweede, indien ervaren huisartsen daadwerkelijk beter gebruik maken van contextuele informatie dan moet dit fenomeen te herleiden zijn tot veranderingen in de structuur van het ziekte script zoals die in het geheugen van de ervaren arts gerepresenteerd wordt. Met name moeten dan veranderingen zijn opgetreden met betrekking tot het compartiment enabling conditions. De verwachting is dat in de kennis van ervaren huisartsen het aandeel van de enabling conditions ten opzichte van de andere ziekte script elementen toeneemt.

Verder is het van belang te onderzoeken hoe deze kennisveranderingen de primaire activatie van ziekte scripts beïnvloeden. De activatie van ziekte script kennis kan immers op drie manieren plaatsvinden: ten eerste via de herkenning van enabling conditions, ten tweede via kennisname van de klacht of een waarneembaar symptoom van de patient, of ten derde via de identificatie van een pathofysiologisch mechanisme. De laatste is zoals we reeds zagen onwaarschijnlijk bij ervaren artsen, aangezien dit redeneermechanisme kenmerkend is voor de nog onervaren student (of arts).

Bij aanwezigheid van ziekte scripts die rijk zijn aan enabling conditions, doet zich de vraag voor in hoeverre activatie van dergelijke scripts gedomineerd wordt door de contextuele informatie als zodanig of dat die slechts in combinatie met de klacht kan geschieden.

Op al deze vragen zoeken we in de navolgende hoofdstukken een antwoord. 
In dit proefschrift exploreren we deze vragen middels experimenteel en quasi-experimenteel onderzoek. Het model van ziekte scripts dient daarbij als het raamwerk om theorievorming omtrent medische expertise te uniformeren.

\section{Overzicht van experimenten}

Dit proefschrift is grotendeels een bundeling van reeds eerder gepubliceerde onderzoeken. Alle (behalve hoofdstuk 6) behandelen zij vroege hypothesevorming in relatie tot contextuele informatie.

Het eerste experiment (hoofdstuk 2) vergelijkt de vroege probleemrepresentatie bij ervaren huisartsen met die van pas afgestudeerde basisartsen op de aanwezigheid van contextuele informatie en brengt deze in relatie met de accuraatheid van diagnostiek. Dit experiment leidde tot de conclusie dat ervaren huisartsen op basis van de klacht en de groene kaart van een patiënt betere diagnostische hypothesen genereren en daarbij intensiever gebruik maken van contextuele informatie dan onervaren basisartsen. Hieruit vloeiden de vraagstellingen van experiment II, III, en IV voort. Afhankelijk van de specifieke vraagstelling brachten we modificaties in de methode aan.

Met het tweede experiment (beschreven in hoofdstuk 3) onderzoeken we of ee causaal verband is aan te tonen tussen het gebruik van contextuele informatie en de kwaliteit van vroege hypothesen door de hoeveelheid beschikbare contextuele informatie te manipuleren.

In hoofdstuk 4 beschrijven we de relatie tussen het aantal jaren huisartsgeneeskundige ervaring en de kwaliteit van eerste hypothesen.

In hoofdstuk 5 beschrijven we experiment III. Hierin worden de verschillen aangetoond tussen basisartsen en ervaren huisartsen met betrekking tot de manier waarop ziekte scripts geactiveerd worden. Meer specifiek: wanneer activeert de klacht ziekte scripts en wanneer activeert de contextuele informatie ziekte scripts?

Experiment IV behandelen we in hoofdstuk 6. Dit onderzoek laat zien welke veranderingen in de structuur van ziekte script kennis ten grondslag liggen aan de gevonden verschillen tussen basisartsen en ervaren huisartsen in de experimenten I, II en III.

Dit proefschrift besluiten we met een beschouwing van de resultaten en conclusies uit de voorafgaande hoofdstukken. Een en ander extrapoleren we naar mogelijke consequenties voor de theorie omtrent medisch probleemoplossen, medisch onderwijs en huisartsgeneeskundige ontwikkelingen zoals de kwaliteitbevordering door middel van standaardontwikkeling. 


\section{Referenties}

Anderson, J.R. (1983). The architecture of cognition. Cambridge, MA: Harvard University Press.

Baddeley, A. (1984). Uw geheugen; Een gids voor gebruikers. Utrecht/Antwerpen: Uitgeverij Het Spectrum.

Barrows, H.S., Feightner, J.W., Neufeld, V.R. \& Norman, G.R. (1978). Analysis of the clinical methods of medical students and physicians. (Report No ODH-PR-233 and ODH-DM-226) Hamilton, Ontario, Canada: McMaster University.

Barrows, H.S. \& Bennett, K. (1972). The diagnostic (Problem solving ) skill of the neurologist. Archives of Neurology, 26, 273-277.

Barrows, H.S., Norman, G.R., Neufeld, V.R. \& Feightner, J. W. (1982). The clinical reasoning of randomly selected physicians in general medical practice. Clinical \& Investigative Medicine, $5(1), 49-55$.

Berne, E. (1977). Intuition and Ego States. San Francisco: Harper \& Row Publishers.

Bolinger, R.E. \& Ahlers, P. (1975). The science of 'pattern recognition'. Journal of the American Medical Association, 233 (12) 1289-1290.

Boshuizen, H.P.A. (1989). De ontwikkeling van medische Expertise; Een cognitief-psychologische benadering. (Academisch proefschrift Rijsuniversiteit Limburg) Haarlem: Thesis Publishers.

Bower, G.H., Monteiro K.P. \& Milligan, S.G. (1978). Emotional mood as a context for learning and recall. Journal of Verbal Learning and Verbal Behavior, 17, 573-587.

Bransford, J.D. \& Johnson, M.K. (1972). Contextual prerequisites for understanding: Some investigations of comprehension and recall. Journal of Verbal Learning and Verbal Behavior, 11, 717-726.

Bransford, J., Sherwood, R., Vye, N. \& Rieser, J. (1986). Teaching thinking and problem solving. American Psychologist, 41, 1078 - 1089.

Brouwer,W. (1963). Huisartsdiagnostiek. Huisarts en Wetenschap. 6, 301.

Clancey, W.J. (1983). The epistemology of a rule-based expert system - a framework for explanation. Artificial Intelligence, 20, 215-251.

Crombie, D.L. (1963 a). Diagnostic Process. Joumal of the Royal College of General Practitioners, 6, 579589.

Crombie, D.L. (1963 b). Diagnostic Methods. The Practitioner, 191, 539-545.

Crombie, D.L. (1963 c). The Procrustean Bed of Medical Nomenclature. The Lancet, (jun), 1205-1206.

de Dombal F.T. (1971). Computer-assisted diagnosis. In: L.G. Whytby \& W. Lutz (Eds.), Principles and practice of medical computing. Edinburgh: Livingstone.

de Dombal, F.T. (1978). Medical Diagnosis from a Clinician's Point of View. Methods of Information in Medicine, 17, 28-35.

Dudley, H.A.F. (1968). Pay-off Heuristics, and Pattern Recognition in the Diagnostic Process. The Lancet, (sept), 723-726. 
Dudley, H.A.F. (1975). Clinical method is all wrong. Medical Hypotheses, 2, 164-167

Eddy, D.M. \& Clanton, C.H. (1982). The art of diagnosis. The New England Journal of Medicine, 306(21), 1263-1268.

Eddy, D.M. (1986). Probalistic reasoning in clinical medicine: Problems and opportunities. In: D. Kahneman, P. Slovic \& A. Tversky (Eds.), Judgement under uncerlainty: Heuristics and biases. (pp. 249-267), London: Cambridge University Press.

Einhom, H.J. \& Hogarth, R.M. (1981). Behavioural decision theory: Processes of judgement and choice. Annual Review of Psychology, 32, 53-88.

Elstein, A.S., Shulman, L.S. \& Sprafka, S.A. (1978). Medical Problem Solving: An Analysis of Clinical Reasoning. Cambridge, Mass.: Harvard University Press.

Elstein, A.S. \& Bordage, G. (1979). Psychology of clinical reasoning. In: G. Stone, F. Cohen \& N. Adler (Eds.), Health psychology: a handbook. (pp. 333-367), San Francisco: Jossey Bass.

Ericsson, K.A., Chase, W.G. \& Faloon, S. (1980). Acquisition of a memory skill. Science, 208, 1181-1182.

van Es, J.C. (1984). Patiënt en Huisarts; Een leerboek huisartsgeneeskunde. Utrecht/Antwerpen: Bohn, Scheltema \& Holkema.

Everwijn, S.E.M. \& de Melker, R.A. (1985). De Werkwijze van Huisarts en Specialist. Huisarts en Wetenschap, 28, 302-306.

Feinstein, A.R. (1967) Clinical Judgement. New York: Robert E. Krieger Publishing Co.

Feltovich, P.J. \& Barrows, H.S. (1984). Issues of generality in medical problem solving. In: H.G. Schmidt \& M.L. De Volder (Eds.), Tutorials in problem-based learning . (pp. 128-142), Assen, The Netherlands: Van Gorcum.

Formijne, P. (1971). Leerboek der anamnese en der fysische diagnostiek. (7e druk), Amsterdam: Scheltema en Holkema.

Gale, J. \& Marsden, P. (1982). Clinical problem solving; The beginning of the process. Medical Education, 16, 22-26.

Gale, J. \& Marsden Ph. (1984). Medical Diagnosis; From Students to Clinician. Oxford University Press.

Gerritsma. J.G.M. \& Smal, J.A. (1982). De werkwijze van huisarts en internist; Een vergelijkend onderzoek met behulp van een interactieve patiëntensimulatie. (Academisch proefschrift Rijsuniversiteit te Utrecht) Utrescht: Wetenschappelijke Uitgeverij, Bunge.

Glaser, R. (1984). Education and thinking; the role of knowledge. American Psychologist, 39(2), 93-104.

Godden, D.R. \& Baddeley, A.D. (1975). Context-dependent memory in two natural environments: on land and under water. British Journal of Psychology, 66, 325-332.

Kahneman, D., Slovic, P. \& Tversky, A. (1986). Judgement under uncertainty: Heuristics and biases. London: Cambridge University Press.

Kassirer, J.P. \& Gorry, A.G. (1978). Clinical Problem Solving: A Behavioural Analysis. Annals of Internal Medicine, 89, 245-255. 
Kassirer, J.P., Kuipers, B.J. \& Gorry, G.A. (1982). Toward a theory of clinical expertise. The American Journal of Medicine, 73, 251-259.

Kern, L. \& Doherty, M.E. (1982). 'Pseudodiagnosticity' in an Idealized Medical Problem-Solving Environment. Joumal of Medical Education, 57, 100-104.

Kleinmuntz, B. (1968).The processing of clinical information by man and machine. In: B. Kleinmuntz (Eds.), Formal representation of human judgment. (pp. 149-186), New York: Wiley.

Knottnerus, J. (1987). Bouwstenen voor een rationele medische besluitvorming. Medisch Contact, 16(42), 501-504.

Kooij van der, S. (1978). Registratie van het Probleem-oplossend Proces. Huisarts en Wetenschap,21, 166-172.

Krol, L.J. (1980). Problem-Solving by the Physician. Huisarts en Wetenschap, 23, 317-321.

Kuyvenhoven, M.M. \& Spreeuwenberg, C. (1984). Huisarts en Diagnostisch Proces. Metamedica, 63, 1934.

Leaper, D.J., Gill, P.W., Staniland, J.R., Horrocks, J.C. \& De Dombal, F.T. (1973). Clinical diagnosis process; An analysis. British Medical Journal, 3, 569-574.

Leaper, D.J., Horrocks, J.C., Staniland, J.R. \& De dombal, F.T. (1972). Computer-assisted diagnosis of abdominal pain using 'Estimates' provided by clinicians. British Medical Journal, 4, 350-354.

Ledley, R.S. \& Lusted, L.B. (1959). Reasoning Foundations of Medical Diagnosis. Science, 130, 9-21.

Leinhardt, G. (1987). Situated knowledge; An example from teaching. The Teachers' Professional Learning Conference. Pittsburgh, Pennsylvania: University of Pittsburgh.

Lusted, L.B. (1965). Logic of diagnostic proces. Methods of Information in Medicine, 4, 63-68.

de Melker, R.A. \& Touw-Otten, F. (1984). Medische Besliskunde. Het Diagnostisch Proces in de Huisartspraktijk. The Practitioner, 1, 649-657.

Miller, G.A. (1956). The Magical Number Seven, Plus or Minus Two: Some Limits on Our Capacity for Processing Information. The Psychological Review, 63, 81-97.

Moser, R.H. (1975). The First Five Minutes. Joumal of the American Medical Association, 231, 1169-1170

Neufeld, V.R., Norman, G.R., Feightner, J.W. \& Barrows, H.S. (1981). Clinical problem-solving by medical students; A cross-selectional and longitudinal analysis. Medical Education, 15, 315-322.

Newell,A., Shaw, J.C. \& Simon, H.A. (1959). Elements of a theory of human problem-solving. Psychological Review, 65, 151-166.

Newell, A. \& Simon, H.A. (1972). Human problem soloing. Englewood Cliffs, NJ: Prentice-Hall.

Norman, G.R., Tugwell P., Feightner J.W., Muzzin Linda L. \& Jacoby L.L. (1985). Knowledge and Clinical Problem-solving. Medical Education, 19, 344-356.

Overholt \& Galen (1977). Clinical chemists take hard look at medicine's information explosion. Journal of the American Medical Association, 238, 2465-2469. 
Patel, V.L. \& Groen, G.J. (1986). Knowledge based solution stategies in medical reasoning. Cognitive Science, 10, 91-116.

Pauker, S.G., Gorry, G.A., Kassirer, J.P. \& Schwartz, W.B. (1976). Towards the simulation of clinical cognition. The American Journal of Medicine, 60, 981-996.

Perfetto, G.A., Bransford, J.D. \& Franks Jeffery J. (1983). Contraints on acces in a Problem Solving Context. Memory \& Cognition, 11, 24-31.

Ridderikhoff, C. (1987). Medische besluitvorming bij Artsen. Medisch Contact, 42(43), 1383-1386.

Ridderikhoff, C. (1986). Decision-making strategies in the general practice. (Niet gepubliceerd academisch proefschrift, Erasmus Universiteit Rotterdam) Rotterdarn.

Ronteltrap, C.F.M. (1990). De rol van kennis in fysiotherapeutische diagnostiek. (Academisch proefschrift Rijsuniversiteit Limburg) Haarlem: Thesis Publishers.

Rooymans, H.G.M. (1969). Oordeel en Vooroordeel in Psychiatrische diagnostiek. (Niet gepubliceerd academisch proefschrift, Rijksuniversiteit te Groningen) Groningen.

Rumelhart, D.E. \& Norman, D.A. (1978). Accretion, tuning and restucturing: Three modes of learning. In: R. Klatzky \& J.W. Cotton (Eds.), Semantic factors in cognition. Hillsdale, New York: Erlbaum.

Sacket, D.L., Haynes, B.R. \& Tugwell, P. (1985). Clinical epidemiology. A basic science for clinical medicine. (2nd. ed.) Boston/Toronto: Little, Brown and Company.

Schadé, E. \& Brouwer, H. (1987). Het diagnostisch proces van huisarts en specialist. Meer overeenkomsten dan verschillen. Airways, 3(6), 5-12.

Schmidt, H.G., Norman, G.R. \& Boshuizen, H.P.A. (1990). A cognitive perspective on medical expertise: Theory and implications. Academic Medicine, 65, 611 - 621.

Schmidt, H.G. \& Boshuizen H.P.A. (1992). On acquiring expertise in medicine. Educational Psychology Review, 5, 1-17.

Schmidt, H.G., Boshuizen, H.P.A. \& Hobus P.P.M. (1988). Transitory stages in the development of medical expertise: The 'intermediate effect' in clinical case representation studies, Proceedings of the Cognitive Science Society Meeting. (pp. 139 - 145), Hillsdale, New York: Lawrence Erlbaum.

Slovic, P., Fischhoff, B. \& Lichtenstein, S. (1977). Behavioural Decision Theory. Annual Review of Psychology, 28, 1-39.

Snoek, J.W. (1989). Het denken van de neuroloog. (Academisch proefschrift Rijsuniversiteit Groningen) Groningen: Computekst.

Style, A. (1979). Intuition and Problem Solving. Journal of the Royal College of General Practitioners, 29, 71-74.

Szucko, J.J. \& Kleinmuntz, B. (1981). Statistical Versus Clinical Lie Detection. American Psychologist, $36(5), 488-496$.

Tversky, A. \& Kahneman, D. (1983). Extensional Versus Intuitive Reasoning: The Conjunction Fallacy in Probability Judgement. Psychological Review, 90(4), 293-315. 
Velden van der, H.M.G. (1983). Diagnose of Prognose. Huisarts en Wetenschap, 26, 125-128.

Verhey, J.B. (1982). Het denkproces van co-assistenten tijdens hun klinische bezigheden. Tijdschrift voor Diergeneeskunde, 107(11), 422-427.

Vlek, C. (1987). Psychologische Besliskunde. Tussen weddenschapswetenschap en professionele beslissingsondersteuning. De Psycholoog, 12(2), 73-86.

van der Vleuten, C.P.M. (1989). Naar een rationeel systeem voor toetsing van studieprestaties in probleemgestuurd medisch onderwijs. Studies naar betrouwbaarheid en validiteit van toesten voor praktische vaardigheden. (Academisch proefschrift Rijsuniversiteit Limburg) Haarlem: Thesis Publishers.

Weed, L.L. (1968). Medical records that guide and teach. New England joumal of Medicine, 278, 593600 .

Weinstein, M. \& Fineberg, H. (1980). Clinical Decision Analysis. Philadelphia: Saunders.

McWhinney, I.R. (1972). Problem-Solving and Decision-making in Primary Medical Practice. Proceedings of the Royal Society Medicine,65, 934-938.

Wortman, P.M. (1966). Representation and strategy in diagnostic problem solving. Human Factors, 8, 4853.

Wulff H.R. (1980). Principes van klinisch denken en handelen. Utrecht: Scheltema en Holkema. 


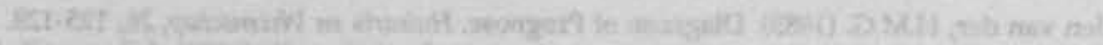

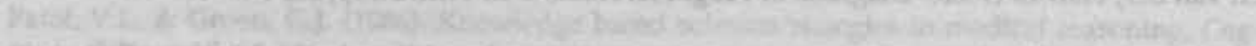

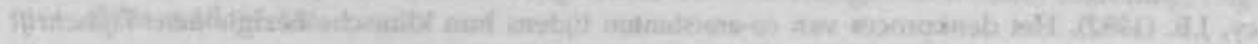

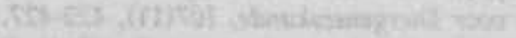

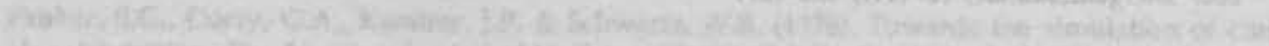

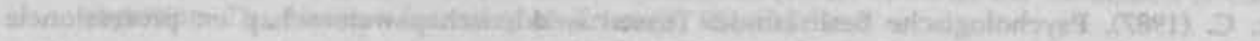

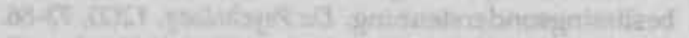

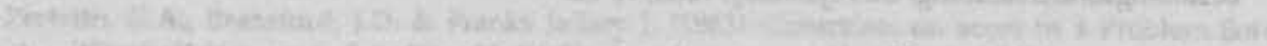

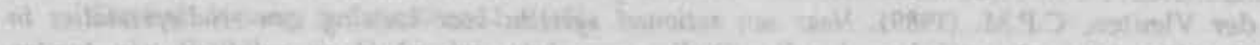

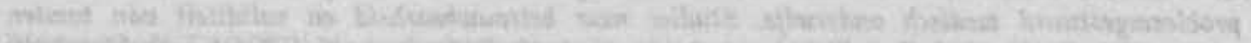

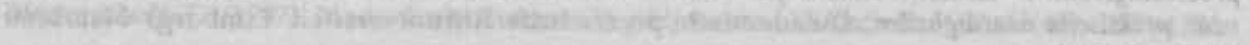

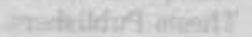

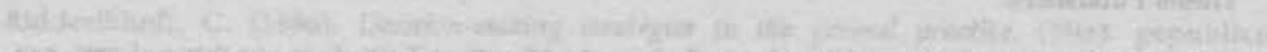

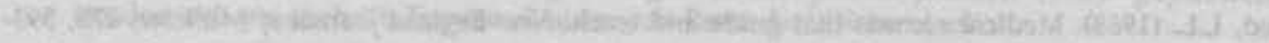

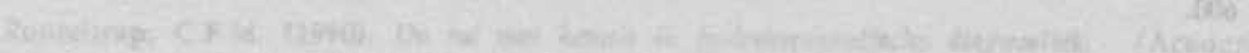

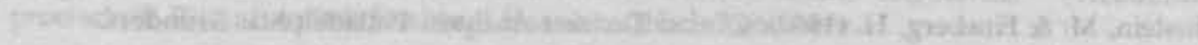

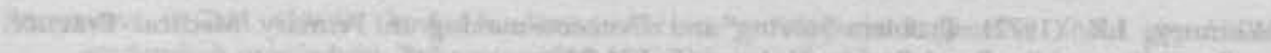

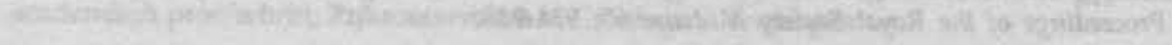

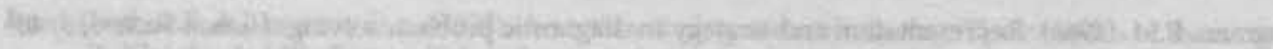

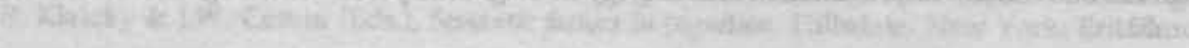

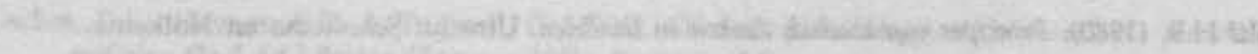
-

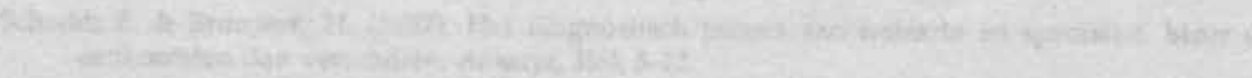

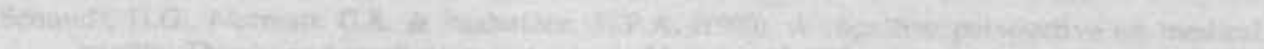

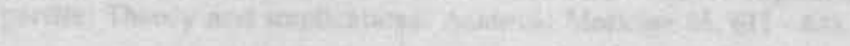

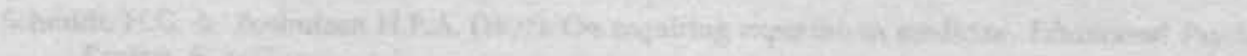

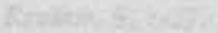

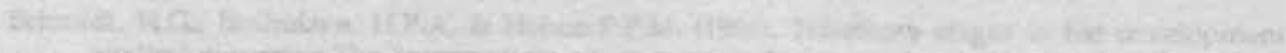

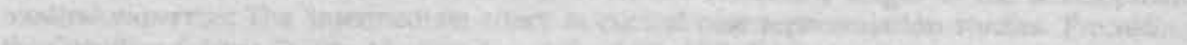

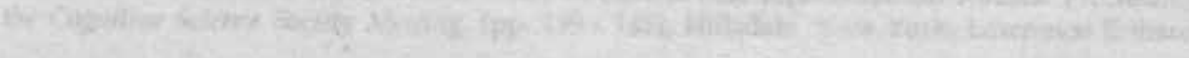

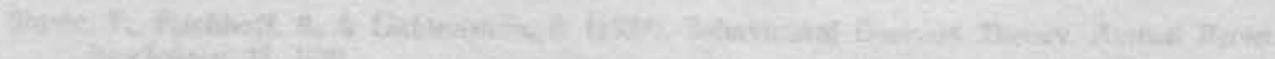

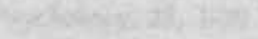

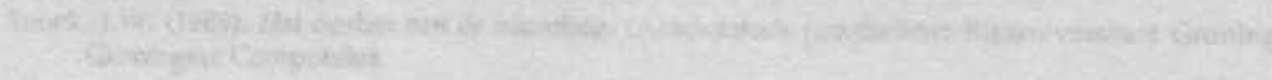

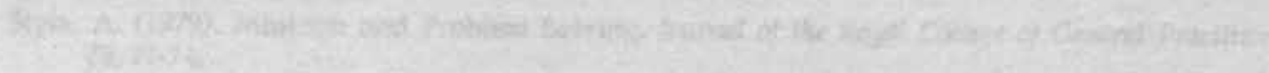

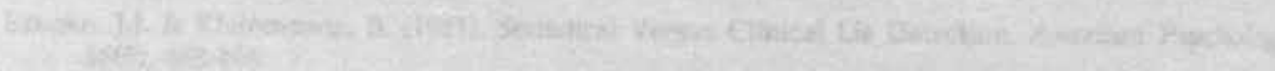

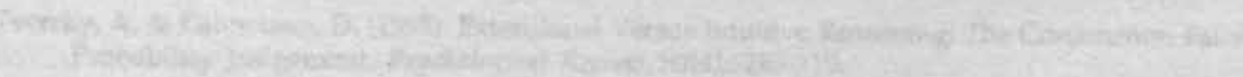




\section{HOOFDSTUK 2}

\section{CONTEXTUAL FACTORS IN THE ACTIVATION OF FIRST DIAGNOSTIC HYPOTHESES: EXPERT-NOVICE DIFFERENCES}

Eerder verschenen als:

Hobus, P. P. M., Schimidt, H. G., Boshuizen, H. P. A., \& Patel, V. L. (1987). Contextual factors in the activation of first diagnostic hypotheses: Expert-novice differences. Medical Education, 21, 471 - 476. 


\section{Summary}

According to Feltovich and Barrows (1984), the general frame used by medical experts to construct a mental representation of a particular patient problern contains a component-part for those illness features that are associated with the acquisition of the illness. These so-called "enabling conditions" are related in several ways to the patient's disease. Examples are: conditions like sex and age; or risk factors originating from work, behaviour and hereditary taint. Because of the sequential nature by which patient data become available during a clinical interview, contextual information is expected to play an important role in the generation of initial diagnostic hypotheses. To investigate the hypothesis that experienced physicians better utilize this kind of information, a group of 18 experts and 17 novices were confronted with 32 short case-histories each presented on three slides: a portrait of the patient, the patient chart containing previous disease history, and a slide with the presenting complaint. It was hypothesized that differences in the number of correct diagnoses would emerge between the two groups, because the experts would use the contextual information, implicitly provided by picture and patient chart, in a more extensive way. If so, this would show in the amount of information that is explicitly recalled later. The data confirmed these predictions. The experts produced almost 50\% more correct hypotheses as compared to the novices and were able to reproduce a larger amount of contextual information in particular information that was directly relevant to the patient's problem. Only the expert group showed a high correlation between accuracy of diagnoses and recall measures. 


\section{Introduction}

Investigations into expert-novice differences in the ability to solve medical diagnostic problems are useful because they may suggest ways to teach this skill. Research in this area indicates that medical experts perform better than novices on a large variety of expertise-related tasks. They are better at diagnosing dermatological diseases presented on slides (Norman, Muzzin, \& Rosenthal, 1985), judging X-rays (Lesgold, Feltovich, Glaser \& Wang, 1981) or recalling clinical cases (Patel \& Groen, 1986). They are faster at processing patient information (Claessen \& Boshuizen, 1985) and show superior recall of texts derived from a medical textbook (Patel, Ho Ping Kong \& Mark, 1984). It is however, largely unclear which factors mediate this superior performance on these tasks. One of the reasons for this shortcoming may be that an articulated theory of expertise in this area, despite several attempts (e.g. Elstein, Shulman \& Sprafka, 1978), is virtually absent.

The purpose of this research is not so much to demonstrate differential abilities between physicians of different levels of expertise in yet another domain, but to look for reasons why these differences arise. In particular we were interested in finding an explanation for the known differences in accuracy of diagnostic hypotheses between experts and novices that emerge during the first moments of a clinical encounter. This expertise-related feature has our special interest because the accuracy of the first hypotheses to a large extend determines the accuracy of the final differential diagnosis (Barrows, Neufeld, Feightner \& Norman, 1978; Barrows, Norman, Neufeld \& Feightner, 1982; Neufeld, Norman, Feightner \& Barrows, 1981). Also, very little experimental research has been done yet, to explore factors involved in hypotheses generation, during the initial problem-solving stages.

Characteristic for the early stage of an encounter is, that apart from the complaint with which the patient confronts his physician, little information is explicitly provided. In contrast, a large amount of information is implicitly available in the situation. One source of information is the patient's non-verbal behaviour and appearance, another is the doctor's prior knowledge about his patient. He knows the kind of diseases the patient has suffered from in the past, the drugs he uses or has been using, and the nature of his work environment. This kind of information provides a context for the complaint which a physician can apply in his search for a likely diagnostic hypothesis explaining the patient's problem. Because of the sequential nature by which patient data become available during a clinical interview, this contextual information is expected to play an important role in the generation of initial hypotheses.

Feltovich and Barrows (1984) developed a theory that may apply to the present: experiment. They suppose that experienced physicians use general knowledge frames (e.g. illness-scripts) to construct a cognitive representation of a particular patient's problem. These illness-scripts consist of three component parts that are interrelated with each other. Those illness features that are associated with the acquisition of 
illness are termed enabling conditions. Instances of enabling conditions are predisposing factors like alcohol and nicotine abuse, or boundary conditions like sex and age. The contextual information discussed previously can be classified as enabling conditions. The second category of features: faults, contain the major malfunctions that lead to the third category of features: consequences. An example is the inadequate oxygen supply (which can be considered the fault) of myocardial tissue, leading to anginal symptoms and eventually cardial or systemic complications (which are the consequences). In the model of Feltovich and Barrows (1984) basic science knowledge (e.g. pathophysiology, anatomy) plays an integral role in the construction of the problem representation by guiding the way in which illness features are structured together.

In order to investigate the role of context in the activation of early hypotheses, family physicians and graduate or near-graduate medical students were presented with 32 short case-histories, each containing a picture of a patient, the previous disease history and the present complaint. The subject read each case, and was asked to formulate a diagnosis. Reading and respons time were fixed. It was expected that differences in the number of correct diagnoses would emerge between the two groups because the contextual information may be more meaningful to experienced physicians and accordingly processed in a more elaborate way. If the more experienced group uses the contextual information provided by the picture and previous disease history in a more elaborative way, leaving memory traces of greater distinctiveness, this would show in the information recalled, because more elaborative processing of information produces better recall (Anderson \& Reder, 1979). Therefore subjects were asked to recall all the information they considered to be important to the case.

\section{Method}

\section{Subjects}

Subjects were 35 physicians and graduate medical students. The group of experts consisted of 18 family physicians who on the average had $11.1 \pm 7.7$ years of experience in health care. Average age was $38.2 \pm 9.1$ years. The novices were 12 final year medical students who were about to graduate and 5 physicians who graduated less than one month prior to the experiment. Their average age was $25.5 \pm 3.3$ years.

\section{Materials}

As was already outlined, enabling conditions are not explicitly available in the early moments of a doctor-patient encounter. An attempt was made to simulate this condition by presenting the information with a portrait and medical card of the patient. In doing so, information could be given about sex, age, profession, previous disease history, etc. in an implicit way. The portrait, patient chart and the presenting complaint were presented on three separate slides. The stimulus materials consisted of 32 case histories selected from a larger set of case-descriptions about patients available at the University of Limburg Medical School. The cases were selected asto have contextual information play an important role in the interpretation of the 
complaint. The pictures were selected from a set of 110 portraits especially produced for the experiment. They were only to convey information concerning age and sex of the patient. Therefore, only pictures were utilized on which the person showed a neutral facial expression and no signs of any disease (like exophthalmus or a drooping corner of the mouth). Previous disease history was typed on a patient chart. In addition, this chart contained information about the patient's profession, marital status, medication, family history of diseases, and risk factors. Data included both relevant and irrelevant information as related to the presenting complaint. The presenting complaint consisted of one or two sentences as expressed by the patient, for instance: "I have a cold fever for already two days long, doctor. I sometimes lie down shaking in my bed". The complaints covered all organ systems.

\section{Procedure}

The 32 cases were presented in a standardized fashion. First, the subject was exposed to the portrait for about 4 seconds, then the patient chart appeared on the screen, followed by the presenting complaint. Because recall, as an important dependent variable, also depends on the duration of information-input, exposure times were fixed. Some patient charts and complaints contained more information than others, therefore exposure-times varied between 3 and 42 seconds for the chart, and between 3 and 9 seconds for the complaint. They were established in several pilots with experts and novices. Mean exposure time per case was 32 seconds. Finally, a black slide was projected for about 15 seconds. During that interval the subject was asked to state the most likely diagnosis, given the information presented. In the present experiment a one-diagnosis respons was preferred rather than a differential diagnosis. By doing so an error-introducing procedure for weighing a list of possible diagnoses produced by a subject can be avoided ${ }^{1}$.

After an instruction session, the 32 cases were presented in two series of 16 each. After both series; each of the 16 presenting complaints was read back to the subject, together with the tentative diagnosis the subject had generated. Subsequently the experimenter asked the subject to recall which information embedded in the case gave rise to the particular hypothesis.

All responses were audiotaped.

Presentation-order of the two series was varied systematically over subjects.

\section{Scoring}

A verbatim transcription was produced from the audiotaped responses.

For each subject and for each case it was determined whether the hypothesis generated was correct and how much information was retained.

\footnotetext{
${ }^{1}$ A most likely diagnosis was asked for two extra reasons: Firstly, because it structures the subjects thoughts, when several possible hypotheses are considered. By adding an hierarchical element utmost utilisation of given information can be expected. This was necessary to elicit the mechanisms we were in search of. And secondly, the concept of the most likely diagnosis is more than being only one diagnosis. It bears traces of all the alternatives in being the most likely of them.
} 
Diagnostic accuracy.

Because no "objective" criterion for deciding whether a hypothesis is "correct", given the restricted information provided to the subjects, the actual diagnosis of the particular patient was used as a criterion. Two judges compared the statement of the subject with the actual diagnosis. Interrater agreement for this task was $95.4 \%$.

Accuracy and completeness of recalled information.

In order to judge how much contextual information about each patient was recalled, the information on the patient chart was segmented into information-units. Recall of complaint information was not included. An information-unit was defined as a statement containing one singular fact or idea. The portrait of the patient and the birth-date on his chart were considered to contain two units of information: sex and age.

For each information-unit it was determined whether it was relevant to the correct diagnosis or not.

The segmented case-information was then compared with the verbatim transcripts of the subjects' responses. The accuracy and completeness of recalled information was determined as follows; of every unit recalled it was decided whether it could be considered literal or paraphrased recall, partial or inferred recall, or a summary of the contextual information presented. These responses were weighed. Each literal or paraphrased information-unit recalled was scored as 3 points. Partial or inferred information units were scored 2 points, whereas a summary was scored as 1 point. For instance, the patient who presented with the complaint of shaking chills was a male born October the $15^{\text {th }}, 1931$. He had had a hematuria, after which carcinoma of the bladder was diagnosed. This diagnosis led to a total cystectomy with diversion of the urine by uretero-ileostomy. Examples of literal or paraphrased recall by subjects are: "fifty-five years old..." and "they removed the bladder...". Examples of partial or inferred statements are: "older patient..." and "bladder operation...". An example of a summary is "there was something in the chart about urinary tract problems...". In this way complete answers of subjects could be scored as follows. With regard to the above described patient-case expert-subject 8 motivated his hypothesis with these statements: "this man has had a total cystectomy, then you get..........there will be an isolated ileal loop with implanted ureters. Well in such a case you often see ascending infections". This subject obtained of 9 points, that is to say, 3 for "man", 3 for "total cystectomy" and 3 for "isolated ileal loop with implanted ureters". Expertsubject 1 was much shorter with his motivation: "I believe there was something on the chart about urinary tract problems, that's why an infection came high on my list. Beside that, fever can be very high then". This subject scored 1 point for his summary as already exemplified above.

Interrater agreement of two judges for this task was $93.4 \%$ on one fifth of the material. The remaining protocols were scored by one judge.

Group differences in diagnostic accuracy and in recall of contextual information were analysed by means of a one-way-analysis-of-variance. 


\section{Results}

Table 2.1 shows the average number of correct hypotheses produced by experts and novices.

Table 2.1: Average number of correct hypotheses, produced by experts and novices (with standard deviations)

\begin{tabular}{llrl} 
& $\mathrm{N}$ & Mean & SD \\
\hline Experts & 18 & 12.11 & 2.52 \\
Novices & 17 & 8.88 & 2.12 \\
\hline
\end{tabular}

$$
F(1,33)=16.75, p=.0003
$$

The observed difference is statistically significant: $F(1,33)=16.75, p=.0003$. This result indicates that experts produce more accurate first hypotheses than novices do, given a very restricted amount of information about a patient.

Recall of information summarized over two series of trials is shown in table 2.2.

Recall of relevant and recall of irrelevant information-units were distinguished.

Table 2.2: Average recall scores by experts and novices (standard deviations between brackets)

\begin{tabular}{lll} 
& \multicolumn{1}{c}{ Experts } & Novioes \\
\hline Total recalled & $216.05(52.84)$ & $163.35(48.56)^{*}$ \\
Relevant & $180.33(40.99)$ & $136.24(36.50)^{* *}$ \\
Irrelevant & $35.74(14.68)$ & $27.11(13.02)^{* * *}$ \\
\hline & $" F(1,33)=9.41 p=.004{ }^{* *} F(1,33)=11.25 p=.002{ }^{* *} F(1,33)=3.35 p=.076$
\end{tabular}

Total amount of information units recalled by the experienced physicians exceed that of the novics: $F(1,33)=9.41, p=.004$. This effect is particularly apparent for the information that was relevant for a correct interpretation of the complaint; $F(1,33)=11.25, p=.002$. The difference in recall of irrelevant information units between the two groups was not significant; $F(1,33)=3.35, p=.078$. Table 2.3 contains correlations between these recall measures and the number of correct hypotheses in each group.

Table 2.3 shows high correlations between total number of accurate hypotheses and recall of contextual information for experts whereas this relationship is virtually absent among novices. 
Table 2.3: Product-moment correlations between number of correct hypotheses and recall measures for each group

Experts Novices

\begin{tabular}{llll}
\hline & & \multicolumn{3}{c}{ correct hypotheses } \\
Total Recall & & .12 \\
Relevant & Recall & $.54^{* *}$ & .15 \\
Irrelevant Recall & $.63^{* *}$ & .03 \\
\hline
\end{tabular}

"p<.05 " $p<.01$

\section{Discussion}

The central thesis of this research is that experts are better able to utilize information implicitly available in an information-restricted environment than novices are, even if this information is not overtly related to the complaint at hand. The data seem to confirm this hypothesis. Firstly, the experts generally produced more accurate diagnoses than the novices. It is interesting to observe how well experts are able to solve a diagnostic problem, in the absence of additional data like results of physical examination or laboratory tests. Even before history-taking they are already on the right track in almost $40 \%$ of the cases. Secondly, table 2 shows that this superior diagnostic performance is accompanied by better recall, in particular of relevant contextual information.

Of course, the data presented do not automatically imply that experts produce better hypotheses because they use contextual information in a more elaborative way. Whether these outcomes reflect a causal relationship between extensive elaboration of contextual information and better diagnoses remains to be questioned. An alternative explanation for the superior performance as shown in Table 1 might be that the experts have better lists of possible diagnoses stored in memory, that are activated by the presenting complaint alone. This would imply that their guesses are better, not so much because contextual factors are critical to their performance, but because they have developed more appropriate lists of diagnoses in relation to certain sets of complaints. However, this alternative explanation cannot account for the observed expert correlations ${ }^{1}$. Since correlations between recall and problem solving measures are absent in the novice group, this alternative hypothesis could eventually provide an accurate model for the well-performing novice.

One might argue that a relation between accuracy of hypotheses and amount of relevant information recalled is an artefact of the experimental procedure, in which subjects were asked to recall all information they considered relevant to the diag-

\footnotetext{
${ }^{1}$ Because recall of complaint information is not included in the scores, in our view these figures can only express a real relationship between extensive recall of contextual information and the production of good hypotheses.
} 
nosis. If such an effect would have mediated the experimental outcome a strong correlation between diagnostic accuracy and relevant recall had to be expected. Such relation happens to be the case in the expert group but correlation is low in the novice group. So, although the elaboration hypothesis at the moment appears to be the best candidate for explaining the results, further research is necessary. For instance, in order to test the "better list" hypothesis an experiment will be designed in which contextual information is deleted for some of the experimental groups. The "better list" hypothesis predicts experts to perform better than novices regardless wether contextual information is provided or not.

\section{Conclusion}

The knowledge activated by the contextual information in the 32 cases covers a broad range of subject-matters, from disease-distributions to side-effects of drugs. Generally, in the training of medical students to become diagnosticians much attention is paid to complaint-exploration and physical examination. This is mainly due to the fact that most of the time training occurs in clinical settings like hospital wards. Moreover, in medical education emphasis lies on anatomic and pathophysiological knowledge in order to let the students understand the patient's symptoms and signs. The results of this experiment, however, indicate that in a critical phase of the diagnostic process another kind of knowledge is used namely that needed to understand the context of a patient.

In conclusion, the data provide some support for the notion that experienced physicians make an extensive use of contextual information while attempting to solve diagnostic problems, at least when no additional information regarding the present condition of the patient is available. They confirm the assertion of Feltovich and Barrows (1984) that enabling conditions form an essential part in the construction of a mental representation of the patient's problem and help the physician to reduce the number of alternatives to be taken into account. The results also indicate that this skill is acquired only through years of clinical practice.

\section{References}

Anderson, J.R. \& Reder, L.M. (1979). An elaborative processing explanation of depth of processing. In: L.S. Cermak \& F.I.M. Craik (eds.), Level of Processing in Human Memory. Hillsdale, NJ: Lawrence Erlbaum.

Barrows, H.S., Neufeld, V.R., Feightner, J.W. \& Norman, G.R. (1978). An Analysis of the Clinical Methods of Medical Students and Physicians. McMaster University, Hamilton, Ontario, Canada.

Barrows, H.S., Norman, G.R., Neufeld, V.R. \& Feightner, J.W. (1982). The clinical reasoning of randomly selected physicians in general medical practice. Clinical \& Investigative Medicine, 5 , 49-55.

Claessen, H.F. \& Boshuizen, H.P.A. (1985). Recall of medical information by students and doctors. Medical Education, 19, 61-67. 
Elstein, A.S., Shulman, L.S. \& Sprafka, S.A. (1978). Medical Problem Solving: An Analysis of Clinical Reasoning. Harvard University Press, Cambridge, Mass.

Feltovich, P.J. \& Barrows, H.S. (1984). Issues of generality in medical problem-solving. In: H.G. Schmidt \& M.L. de Volder (Eds.), Tutorials in Problem-Based Learning. Assen, the Netheriands: Van Gorcum.

Lesgold, A.M., Feltovich, P.J., Glaser, R. \& Wang, Y. (1981). The Acquisition of Perceptual Diagnostic Skill in Radiology. Technical Report No. PDS-1. Learning Research and Development Centre, University of Pittsburgh, Pittsburgh, PA.

Neufeld, V.R., Norman, G.R., Feightner, J.W. \& Barrows, H.S. (1981). Clinical problem-solving by medical students: a cross-sectional and longitudinal analysis. Medical Education, 15, 315-322.

Norman, G.R., Muzzin, L.J. \& Rosenthal, D. (1985). Expert-Novice Differences in Perception and Categorization in Dermatology. Paper presented at the Annual Meeting of the American Educational Research Association, Chicago, IL.

Patel, V.L. \& Groen, G.J. (1986). Knowledge based solution strategies in medical reasoning. Cognitive Science, 10, 91-116.

Patel, V.L., Ho Ping Kong, H. \& Mark, V. (1984)., The role of prior knowledge in the interpretation of medical texts by medical students and physicians. Proceedings of Research in Medical Education. Association of American Medical Colleges, Washington, DC. 


\section{HOOFDSTUK 3}

\section{DE CONTEXT VAN DE KLACHT ALS DIAGNOSTICUM}

Eerder verschenen als:

Hobus, P.P.M., Hofstra, M., Boshuizen, H.P.A., \& Schmidt, H.G. (1988). De context van de klacht als diagnosticum. Huisarts en Wetenschap, 31, 261-263. 


\section{Samenvatting}

Is het waar dat de huisarts gebruik maakt van zijn voorkennis over een patiënt wanneer hij diens klacht interpreteert? Deze veronderstelling komt herhaaldelijk in de literatuur naar voren. Aansluitend op eerdere onderzoeksresultaten is een experiment uitgevoerd waarin gepoogd wordt deze oraag te beantwoorden. Met name is ingegaan op de vraag of er een causaal verband is tussen het gebruik van zogenaamde contextuele informatie en de kwaliteit van vroege diagnostische hypothesen. (Contextuele informatie is alle informatie die reeds op het moment van de klacht-presentatie impliciet voorhanden is.)

Hierbij is gebruik gemaakt van een methode waarbij de eerste momenten van een consult worden gesimuleerd met behulp van een diapresentatie. De kwaliteit van vroege diagnostische hypothesen in 18 consultfasen wordt onderzocht en vergeleken in een groep van 16 ervaren huisartsen enerzijds, en 16 relatief onervaren basisartsen anderzijds.

De resultaten laten zien dat alleen ervaren huisartsen gebruik maken van contextuele informatie en daarom betere diagnostische hypothesen genereren dan basisartsen. 


\section{Inleiding}

Het is bekend dat een huisarts al vroeg in het consult hypothesen genereert omtrent de uiteindelijke diagnose (Barrows, Norman, Neufeld \& Feightner, 1982; Elstein, Shulman \& Sprafka, 1978). In de literatuur worden met een zekere vanzelfsprekendheid een aantal zaken geponeerd die daarmee samenhangen. Zo wordt er gesteld dat er ten aanzien van het proces waarmee hypothesen gegenereerd worden, sprake is van patroonherkenning en intuïtie (Sackett, Haynes \& Tugwell, 1985; Style, 1979; Touw-Otten, 1983). Ook suggereert men dat de voorkennis die huisartsen over hun patiënten hebben, alsmede hun epidemiologische kennis, een belangrijke rol spelen in de eerste diagnostische overwegingen (van Es, 1984; Knottnerus, 1986; Kuyvenhoven \& Spreeuwenberg, 1984; Moser, 1975; Velden van der, 1983; Wulff, 1980). Het blijkt echter moeilijk na te gaan in hoeverre de hier gerefereerde auteurs zich baseren op theoretische overwegingen en eigen indrukken, of dat zij hun uitspraken doen op geleide van resultaten van gericht wetenschappelijk onderzoek.

Het is daarom niet bekend of huisartsen tijdens hun diagnostiek daadwerkelijk voorkennis over een patiënt gebruiken, wanneer ze dat doen, en wat de precieze invloed daarvan op de kwaliteit van de diagnostiek is.

Men kan zich voorstellen dat, op het moment van binnenkomst van een patiënt in de spreekkamer, bij de huisarts voorkennis over die patiënt geactiveerd wordt. Deze voorkennis zou tezamen met andere op dat moment impliciet in de situatie aanwezige informatie, zoals leeftijd en geslacht van de patiënt, een rol kunnen spelen in de eerste diagnostische overwegingen die bij de huisarts opkomen naar aanleiding van de door de patiënt geuite klacht. De voorkennis die bij de arts geactiveerd wordt, kan bijvoorbeeld bestaan uit kennis die hij over zijn patiënt heeft aangaande diens medische voorgeschiedenis, risicogedrag, beroep, familiair voorkomende aandoeningen, psycho-sociale achtergrond en niet te vergeten medicijngebruik. Deze gegevens, die alle betrekking hebben op de context waarin een klacht ligt ingebed, worden wel contextuele gegevens (Hobus, Schmidt, Boshuizen \& Patel, 1987) genoemd.

Deze gedachte heeft eerder bij ons aanleiding gegeven tot een experiment waarbij met behulp van zeer korte casuspresentaties werd nagegaan in hoeverre ervaren huisartsen en onervaren basisartsen genoemde contextuele informatie gebruiken tijdens het vormen van eerste diagnostische hypothesen; tevens werd onderzocht of intensief gebruik van deze informatie de kwaliteit der hypothesen beïnloedt. De casus werden als volgt aangeboden. Met behulp van een diapresentatie werden het portret, de groene kaart en de klacht van elke patiënt getoond. De proefpersonen werd verzocht telkenmale met behulp van deze summiere informatie een hypothese omtrent de diagnose te genereren. Op die manier werd als het ware het begin van een consult gesimuleerd. Naderhand werd hun gevraagd welke informatie van de aangeboden casus zij zich nog herinnerden. Hieruit kwam naar voren dat de ervaren huisartsen ten opzichte van de 'onervaren' basisartsen niet alleen meer goede hypothesen noemden, maar ook naderhand meer informatie van de groene 
kaart en portret naar voren brachten. Dit suggereert een intensiever gebruik van contextuele informatie door ervaren huisartsen. ${ }^{1}$

Echter, het achteraf beter herinneren van bepaalde informatie bewijst nog niet dat die informatie daadwerkelijk tijdens het diagnostisch denkproces gebruikt is om goede hypothesen te genereren. Een andere verklaring voor de betere diagnostische prestatie van ervaren huisartsen zou bijvoorbeeld kunnen zijn, dat hun diagnostische overwegingen beter afgestemd zijn op de klacht van de patiënt. In het onderzoek werd namelijk gebruik gemaakt van uit de huisartsgeneeskundige praktijk afkomstige casuïstiek. De kennis omtrent prevalenties van aandoeningen bij bepaalde klachten in de eerste lijn zou bij huisartsen beter kunnen zijn dan bij basisartsen, die vanwege hun ervaringen opgedaan tijdens coschappen in ziekenhuizen mogelijk sterk beïnvloed zijn door het aanbod van geselecteerde patiënten.

Om de hypothese te toetsen, dat intensiever gebruik van contextuele informatie direct ten grondslag ligt aan de betere diagnostische prestaties van huisartsen ten opzichte van basisartsen, is het nu volgende experiment uitgevoerd. Hierin wordt gebruik gemaakt van twee soorten casuistiek: klachten zonder en klachten met contextuele informatie. Indien de ervaren huisartsen betere hypothesen genereren omdat alleen zij gebruik maken oan contextuele informatie, zal alleen deze groep betere prestaties leveren bij de klachten mèt context.

\section{Methoden}

\section{Materiaal}

In ons eerdere experiment (Hobus, Schmidt, Boshuizen \& Patel, 1987) werd de vroegste fase van een consult gesimuleerd door een diapresentatie van het portret, de groene kaart en de klacht van de patiënt. De gebruikte casus zijn ontleend aan een bestand van ca. 600 huisartsgeneeskundige casus die bij de Rijksuniversiteit Limburg bij elkaar zijn gebracht ten behoeve van onderwijs en onderzoek ${ }^{2}$. Uit dit bestand zijn 32 casus geselecteerd waarbij informatie over de context van de klacht een rol kan speler bij de verdere interpretatie van de klacht. Zoals al aangegeven is, verstaan we onder contextuele informatie die informatie die, naast de expliciet geuite klacht van de patiënt, impliciet aanwezig is, zoals geslacht en leeftijd van de patiënt en voorkennis van de huisarts over de patiënt. Bepaalde nonverbale gegevens van de patiënt, zoals gelaatsexpressie en lichaamshouding, werden in dit experiment buiten beschouwing gelaten. De gebruikte portretten dienden slechts ter overdracht van informatie betreffende leeftijd en geslacht. Deze werden geselecteerd uit 110 portretfoto's door 3 artsen en 3 leken, waarbij een neutrale gelaatsexpressie als criterium werd gehanteerd. Om het impliciete karakter van contextuele informatie te behouden werd deze informatie gepresenteerd in de vorm van een portret en

${ }^{1}$ Cognitief psychologisch onderzoek heeft aangetoond dat die elementen waaraan in de bestuderingsfase van gegevens meer aandacht is besteed, meer kans maken op een later tijdstip herinnerd te worden.

2Met dank aan Drs. B.F. Stalenhoef-Halling (gestorven op 28 nov. 1992) voor het bereidwillig ter beschikking stellen hiervan. 
groene kaart van de patiënt. Slechts een gedeelte van de informatie die opgesloten lag in het portret en groene kaart was relevant voor een correcte interpretatie van de klacht.

\section{Huidige experiment}

Op grond van psychometrische overwegingen ${ }^{1}$ worden ten behoeve van het huidige vervolgexperiment, uit het oorspronkelijke materiaal 18 casus geselekteerd (zie tabel 3.1).

Tabel 3.1: Diagnosen behorend bij het geselecteerde casusmateriaal (inclusief twee oefencasus)

\begin{tabular}{|l|l|}
\hline Aften & Bofmeningitis \\
\hline Aneurysma aortae & Myocardinfarct \\
\hline Candidavaginitis bij diabetes mellitus & Gastritis \\
\hline Dermatitis perioralis & Niersteenkoliek \\
\hline Digitalisintoxicatie & Otitis media perforata \\
\hline Enuresis nocturna & Pancreas(kop)carcinoom \\
\hline Functionele buikklachten & Pediculosis pubis \\
\hline Hepatitis A & Spruw \\
\hline Herpes zoster & Subduraal hematoom \\
\hline Longmetastasen bij adenocarcinoom colon & Urosepsis \\
\hline
\end{tabular}

Deze casus worden onder twee condities gepresenteerd.

In de ene conditie worden de 18 klachten zonder contextuele informatie aangeboden; dus zonder portret en groene kaart. Na iedere dia met daarop een zin die de klacht verwoordt, volgt een blanco dia. In de andere conditie worden de 18 klachten wel gecombineerd met de daarbijbehorende contextuele informatie: telkens wordt na de klacht-dia de dia met het portret, daarna de dia met de groene kaart en tenslotte een blanco dia gepresenteerd (zie figuur 3.1).

\section{Proefpersonen}

Proefpersonen zijn huisartsen met minimaal 4 jaar ervaring, en basisartsen die korter dan 6 maanden voor de afname van het experiment afstudeerden, of dit binnen 6 maanden gingen doen. De deelnemers zijn telefonisch benaderd in een zogenaamde sneeuwbalprocedure: kennissen werden gevraagd mee te doen, waarna zij weer collegae noemden die daarna gevraagd werden. Slechts enkele personen waren niet in staat tot deelname in verband met drukke werkzaamheden. De groep huisartsen bestaat uit 16 personen met een gemiddelde ervaring als huisarts van 15.1 jaren (spreiding: $4-38$ jaar).

De groep basisartsen bestaat uit 16 (bijna) artsen, waarvan 3 nog niet, en 13 al wel afgestudeerd zijn (gemiddeld 3 maanden).

\section{Afname- en scoringsprocedure}

Afname vindt individueel plaats. De casus worden gepresenteerd onder standaardtijdcondities: dat wil zeggen dat de expositietijd der dia's gefixeerd is.

${ }^{1}$ Casus met lage item-totaal correlaties in het eerdere experiment werden geschrapt. 
Casus met contextuele informatie

Dia 1 laat gedurende 8 seconden de volgende klacht zien:

"Ik ben enkele keren niet goed geworden, mijn hart ging dan zo tekeer. En verder heb ik de laatsle dagen een paar keer moeten overgeven".

Dia 2 toont vervolgens gedurende 4 seconden het portret van een 71 -jarige vrouw.

Dia 3 toont gedurende 42 seconden de volgende groene kaart:

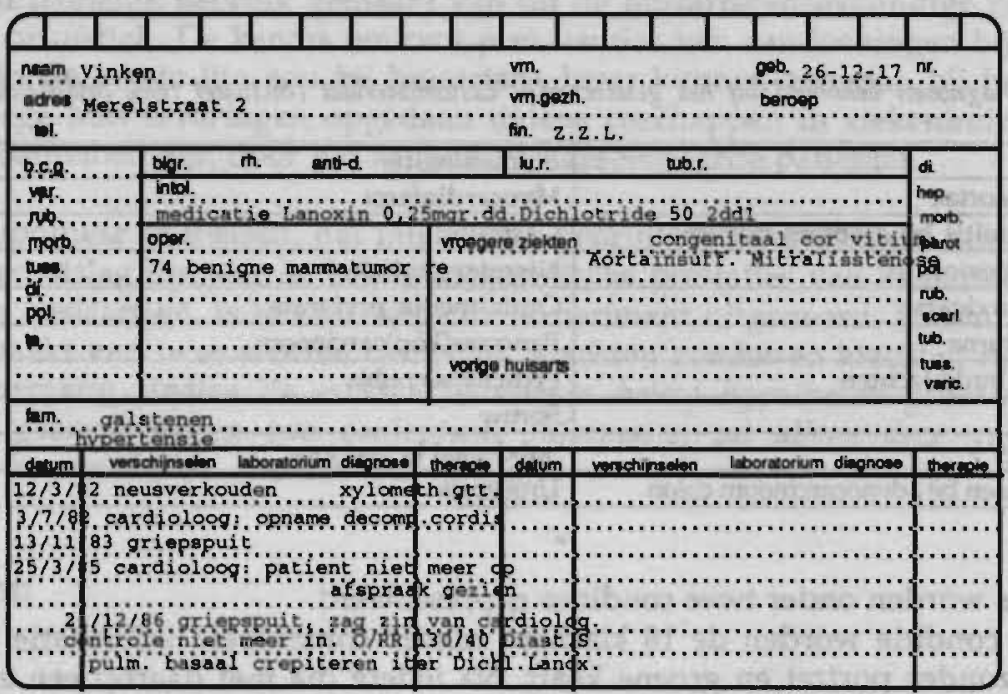

Dia 4 tenslotte is blanco; de proefpersoon heeft 15 seconden de tijd om de meest waarschijnlijke diagnostische hypothese te formuleren".

"Het betreft hier een patient met een digitalisintoxicatie. De leeftijd en de daarmee geassocieerde verminderde nierfunctie, het gebruik van een thiazidediureticum in combinatie met digoxine in een dosering van 1/4 mgr. per dag, en een matige patient-compliance ten aanzien van gewenste cardiologische controles, zou de proefpersoon op het spoor van een digitalisintoxicatie kunnen brengen.

Figuur 3.1: Voorbeeld (casus 10) zaals gepresenteerd in de conditie waarin naast de klacht tevens contextuele informatie gegeven werd.

Per casus is dit gemiddeld 32 seconden. Iedere proefpersoon krijgt daardoor per casus dezelfde verwerkings- en antwoordtijd. Om eventuele volgorde-effecten tegen te gaan wordt de volgorde waarmee de casus worden gepresenteerd, gevarieerd. De huisartsen en de basisartsen worden at random verdeeld over de twee condities, waardoor er geen verschil is in gemiddelde ervaring der huisartsen per conditie. ledere proefpersoon krijgt aldus of 18 casus zonder of (dezelfde) 18 casus met context gepresenteerd. Na een schriftelijke instructie en een tweetal oefençasus, volgt de feitelijke afname. 
De opdracht na iedere casus is om, gegeven de informatie, de meest waarschijnlijke hypothese te noemen. De proefpersoon heeft hiervoor telkens 15 seconden de tijd. Antwoorden worden op audiocassetteband vastgelegd.

De juistheid van de door de proefpersonen genoemde diagnostische hypothesen wordt als volgt vastgesteld: als criterium voor de juistheid wordt de authentieke diagnose van de patiënt genomen; twee onafhankelijke artsen-beoordelaars vergelijken de uitspraken van de proefpersonen met deze authentieke diagnoses. (De interbeoordelaars- overeenkornst bedraagt $94,4 \%$.) Verschillen tussen de groepen worden met behulp van een 2-weg variantieanalyse getoetst.

\section{Resultaten}

Figuur 3.2 toont het gemiddelde aantal correcte hypothesen per groep en per conditie in een histogram.

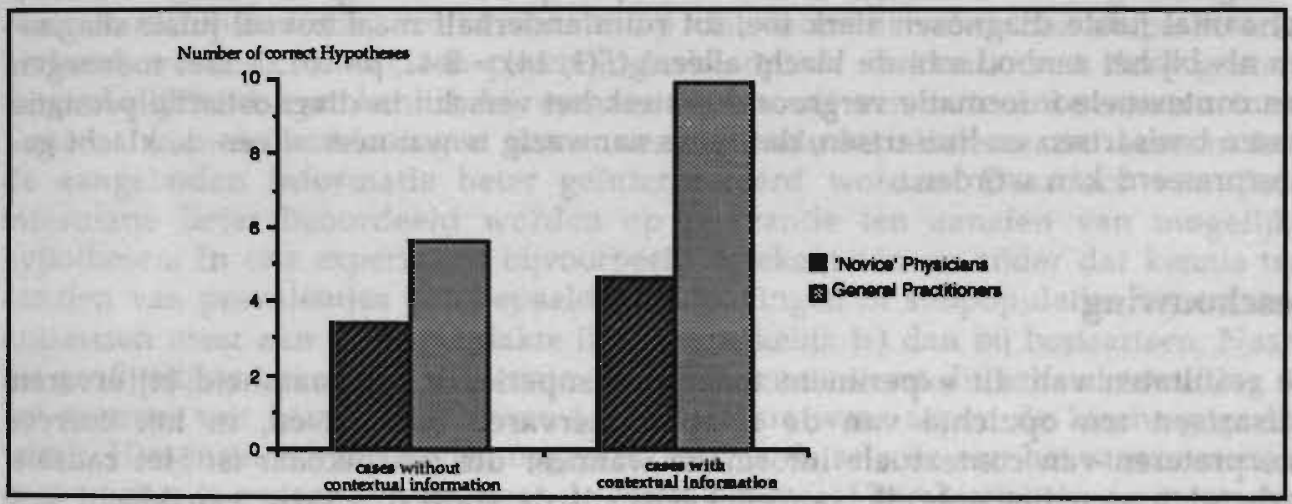

Figuur 3.2: Gemiddeld aantal correcte diagnosen per conditie. Mean number of correct diagnostic hypotheses of $G P_{s}^{\prime}$ and inexperienced physicians in two conditions

Duidelijk is te zien dat met name de huisartsen in de conditie waarin naast de klacht tevens contextuele informatie wordt aangeboden, een groter aantal correcte hypothesen uiten dan de basisartsen. De basisartsen blijven, onafhankelijk van het al dan niet aanbieden van contextuele informatie, gemiddeld nagenoeg hetzelfde aantal correcte hypothesen produceren. De gemiddelde scores en standaarddeviaties van de vier groepen zijn weergegeven in tabel 3.2

Tabel 3.2: Gemiddeld aantal juiste diegnosen per conditie

\begin{tabular}{lcccc}
\hline Conditie & \multicolumn{2}{c}{ Basisartsen } & \multicolumn{2}{c}{ Huisartsen } \\
& $X$ & SD & $X$ & SD \\
\hline Klacht zonder context & 3.38 & 1.30 & 5.63 & 2.07 \\
Klacht met context & 4.63 & 1.77 & 9.88 & 2.56 \\
\hline
\end{tabular}


Uit een 2-weg variantieanalyse blijkt, dat het effect van expertise op het geproduceerde aantal juiste diagnoses significant is $(F(1,28)=28.51 ; p=.0001$.). Dit geldt ook voor het effect van het aanbieden van contextuele informatie op de hoeveelheid juiste antwoorden $(F(1,28)=15.33 ; p=.0005$.).

Ten aanzien van de door ons onderzochte vraag of alléén huisartsen contextuele informatie gebruiken, moet gekeken worden naar interactie tussen expertise en de gepresenteerde conditie. Deze blijkt significant aanwezig. ( $F((1,28)=4.56 ; p=.042)$. Dit betekent dat de score van de huisartsen in tegenstelling tot die van de basisartsen beinvloed wordt door het aanbieden van contextuele informatie.

De sterkte van de enkelvoudige effecten zijn als volgt. Wanneer alleen de klacht wordt aangeboden, scoren zowel basisartsen als huisartsen relatief laag: resp. 3.38 en 5.63 goede diagnoses bij in totaal 18 casus. Het verschil tussen huisartsen en basisartsen is echter wel significant $(F(1,14)=6,79 ; p=.021$.). Wanneer behalve klacht ook context wordt aangeboden, neemt het aantal juiste diagnosen bij basisartsen niet belangwekkend toe: tot $4.63(F(1,14)=2.59 ; p=.130)$. Echter bij de huisartsen neemt het aantal juiste diagnosen sterk toe, tot ruim anderhalf maal zoveel juiste diagnosen als bij het aanbod van de klacht alleen! $(F(1,14)=8.41 ; p=.012)$. Het toevoegen van contextuele informatie vergroot dus sterk het verschil in diagnostische prestatie tussen basisartsen en huisartsen, dat reeds aanwezig is wanneer alleen de klacht geinterpreteerd kan worden.

\section{Beschouwing}

De resultaten van dit experiment tonen een superieure bekwaamheid bij ervaren huisartsen ten opzichte van de relatief onervaren basisartsen, in het correct interpreteren van contextuele informatie wanneer die beschikbaar is. Het causale verband tussen het gebruik van gegevens uit de context waarin een klacht ligt ingebed en het overwegen van een groter aantal juiste diagnostische hypothesen, zoals reeds vermoed in vorig onderzoek (Hobus, Schmidt, Boshuizen \& Patel, 1987), is hiermee aangetoond.

In hoeverre zijn deze resultaten door te trekken naar de dagelijkse praktijk? Het is moelijk voor te stellen dat het gebruik van contextuele informatie door huisartsen beperkt is tot de gecreëerde experimentele situatie, en daarom niet als een kenmerk van dagelijkse huisartsgeneeskundige diagnostiek gezien kan worden. Wanneer we ceze resultaten naar de dagelijkse praktijk extrapoleren moet er wel een kanttekening gemaakt worden. Deze kanttekening betreft de casuskenmerken die voortvloeien uit de toegepaste selectie. Alle gebruikte casus bevatten namelijk so wie so één tot meerdere contextuele gegevens, die relevant zijn voor het bereiken van een correcte diagnostische hypothese. Deze situatie doet zich in de dagelijkse praktijk natuurlijk niet bij iedere patiënt en iedere klacht voor. Er zijn tal van aandoeningen te bedenken waarbij het belang van de contextuele informatie minder is dan in het door ons gebruikte materiaal. Daar staat tegenover dat er in de werkelijkheid hypothesen omtrent de diagnose gegenereerd worden op basis van "contextuele cues" die in dit onderzoek niet zijn meegenomen, zoals lichaamshouding of stemming van 
de patiënt. Het feit dat contextuele gegevens een bijdrage kunnen vormen aan de diagnostiek, lijkt ons evenwel overduidelijk aangetoond.

Het effectief gebruik van contextuele informatie door huisartsen suggereert een grotere gevoeligheid bij deze groep artsen voor het feit dat bepaalde patiëntkenmerken risico's met zich meebrengen ten aanzien van het ontwikkelen van bepaalde ziekten. De leeftijd en het geslacht, het gebruik van bepaalde medicijnen, vroegere ziekten, etc., verhogen of verlagen het risico op het ontwikkelen van bepaalde aandoeningen. Men kan ervan uit gaan dat ook basisartsen zulk soort kennis bezitten. Het is echter frappant dat zij in de toepassing daarvan weinig succesvol zijn, zoals tot uiting komt in het feit dat hun prestaties niet beïnvloedt worden door de aanwezigheid van contextuele informatie. Bij de huisartsen daarentegen is dat duidelijk wel het geval. Deze verschillen tussen de groepen zijn hoogstwaarschijnlijk het gevolg van verschillen in toegankelijkheid van hun kennis. Met name het al dan niet gemakkelijk activeren van kennis die tot de epidemiologie wordt gerekend, bepaalt of er intensief gebruik wordt gemaakt van contextuele informatie, en of daarin op dat moment relevante risicofactoren herkend worden. Vanuit een psychologische optiek verklaart men deze grotere toegankelijkheid van kennis bij ervaren artsen uit een betere kennisstructuur. Doordat er meer verbindingen tussen verschillende kenniselementen bestaan kan de aangeboden informatie beter geïnterpreteerd worden. Daardoor kan deze informatie beter beoordeeld worden op relevantie ten aanzien van mogelijke hypothesen. In ons experiment bijvoorbeeld betekent éen en ander dat kennis ten aanzien van prevalenties van bepaalde aandoeningen in subpopulaties bij ervaren huisartsen meer aan de oppervlakte ligt (toegankelijk is) dan bij basisartsen. Naast het profijtelijker gebruiken van contextuele informatie komt dit zelfs al tot uiting in het vormen van betere hypothesen in de conditie waar alleen de klacht gegeven wordt. Hier moet echter worden opgemerkt dat in de selectie van het casusmateriaal geen poging is gedaan om de, voor de eerste lijn meest karakteristieke (= meest frequente) klacht-diagnose combinaties te selecteren. Voorzover hiervan wel sprake is, kan de betere epidemiologische kennisstructuur van ervaren huisartsen een verklaring vormen voor hun correctere diagnoses bij het horen van een klacht alleen.

Veranderingen in structuur van epidemiologische kennis bij de huisarts ontstaan direct onder invloed van het dagelijks kennisgebruik. Deze veranderingen hebben waarschijnlijk niet zozeer te maken met het bijstellen van aan prevalenties gekoppelde kansschattingen, zoals aanhangers van besliskunde kunnen veronderstellen. Vanuit de specifieke optiek van de besliskunde namelijk, zou het resultaat van deze studie aanleiding kunnen geven te geloven, dat huisartsen betere kwantitatieve afwegingen maken met behulp van a priori kansen. Afgezien van het feit dat oudere artsen ten opzichte van jongere vaak het onderspit delven bij het toepassen van statistische concepten (Berwick, Fineberg \& Weinstein, 1981), zijn strikte cijfermatige schattingen onzes inziens niet noodzakelijk om correcte hypothesen te vormen. Veeleer zal een afweging op ordinaal niveau plaatsvinden, bijvoorbeeld: bij roken heb je meer kans op longkanker dan bij niet-roken, in plaats van deze kansen getalsmatig te kwantificeren. 
Naast de conclusie dat ervaren artsen bij hun diagnostiek meer gebruik maken van contextuele informatie kunnnen we tevens concluderen dat contextuele informatie bij diagnostiek van huisartsen een belangrijke rol kan spelen. Daarmee is een veronderstelling zoals elders in de literatuur naar voren gebracht wordt empirisch bevestigd. Deze bevinding is voor de eerste lijn een heel belangrijke. Ten eerste: door op een dergelijke wijze met informatie om te gaan wordt een efficiente (en dus goedkope!) diagnostiek bevordert. Ten tweede: sluit het hier gevonden fenomeen goed aan bij het begrip 'continuïteit van zorg' (Grol, Smits, Fransen, Huygen \& van Weel, 1987). De ervaren huisartsen namelijk plaatsen de huidige hulpvraag van de patient duidelijk in zijn 'historische' context, en zijn alert op het vinden van een verband tussen beide. Uit het feit dat ervaren huisartsen aldus mér uit de beginfase van een consult weten te halen dan pas beginnende artsen, blijkt dat huisartsen zich deze kunst door praktische omgang met patiënten meester maken. Of deze kunst dientengevolge met de jaren nagenoeg eindeloos toeneemt, of dat huisartsen na een $X$-aantal jaren op het hoogtepunt van hun diagnostisch kunnen geraken (en daarna mogelijk zelfs verslechteren,) zal in een volgend artikel beschreven worden.

\section{Referenties}

Barrows, H.S., Norman, G.R., Neufeld, V.R. \& Feightner, J.W. (1982). The clinical reasoning of randomly selected physicians in general medical practice. Clinical \& Investigative Medicine, 5 , 49-55.

Berwick, D. M., Fineberg, H. V. \& Weinstein, M. C. (1981). When doctors meet numbers. The American lournal of Medicine, 71, 991-998.

Elstein, A.S., Shulman, L.S. \& Sprafka, S.A. (1978). Medical problem solving. An analysis of clinical reasoning. Cambridge: Harvard University Press.

van Es, J.C. (1984). Patiënt en Huisarts; Een leerboek huisartsgeneeskunde. Utrecht/Antwerpen: Bohn, Scheltema \& Holkema.

Grol, A., Smits, A., Fransen, H., Huygen, F. \& van Weel, C. (1987). Continuilteit in de huisartsgeneeskunde. Huisarts en wetenschap, 9, 275-280.

Hobus, P. P. M., Schmidt, H. G., Boshuizen, H. P. A. \& Patel, V. L. (1987). Contextual factors in the activation of first diagnostic hypotheses: Expert-novice differences. Medical Education, 21, 471 476.

Knottnerus, J. A. (1986). Diagnostische hypothesen en a priori kansen in de huisartsgeneeskunde. Huisarts en Wetenschap, 29, 269-273.

Kuyvenhoven, M. M. \& Spreeuwenberg, C. (1984). Huisarts en Diagnostisch Proces. Metamedica, 63, 19 34.

Moser, R. H. (1975). The First Five Minutes. Journal of the American Medical Association, 231, 11691170.

Sackett, D.L., Haynes, B.R. \& Tugwell, P. (1985). Clinical Epidemiology. A basic science for clinical medicine. Boston, Toronto: Little Brown and Company. 
Style, A. (1979). Intuition and problem solving. I oumal of the Royal College of General Practitioners, 29, 71- 74 .

Touw-Otten, F. (1983). Wat doet de dokter? De bijdrage van medische besliskunde en protocollen hierbij. In: Nieuw kompas voor de huisarts. (pp 5.1 - 5.15), Utrecht, Antwerpen: Bohn, Scheltema \& Holkema.

Velden van der, H. M. G. (1983). Diagnose of Prognose. Huisarts en Wetenschap, 26, 125-128.

Wulff, H.R. (1980). Principes van klinisch denken en handelen. Utrecht: Scheltema en Holkema. 


\section{Synopsis}

The context of the complaint as a diagnostic tool

\section{Introduction}

In an earlier experiment, carried out with the aid of 32 very brief case presentations, we studied the question to what extent experienced experienced GPs and beginning physicians use 'contextual information' in forming their first diagnostic hypotheses. We also investigated whether intensive use of such information affected the quality of the hypotheses. The cases were presented as follows: slides were projected showing the patient's portrait, his medical card and his complaint. The subjects were invited to develop a hypothesis about the diagnosis using this concise information. Later they were asked to recal lthis case information.

The GPs' not only advanced more correct hypotheses than the beginners, but could also recall more information from the patient card and portait. These differences could be an effect of interpreting complaint information as well as contextual information. In order to test the hypothesis that the GPS' better diagnostic performance was directly due to the interpretations of contextual information, a second experiment was carried out. It was expected that the availability of contextual information would provide for better dianostic accuracy in a GP group and not in a group of beginning physicians.

\section{Methods}

For this experiment 18 cases were selected in which information about the context of the complaint might be of importance for reaching the correct diagnosis. These cases were presented in two different ways. One way was to present them without contextual information, i.e. without portrait or medical card of the patient. The other way was to present the complaint in combination with the corresponding information.

Serving as subjects were 16 GPs with a minimum of four years' experience, and 16 'beginners' who either had graduated less than six months previously or were expected to graduate within six months.

The cases were presented one by one with a standardized time schedule. This amounted to an avarage of 32 seconds per case. In order to eliminate any sequence effects, the sequence in which the case were presented was varied. The GPs and the 'beginners' were divided at random over the two ways of presentation.

The presentation was preceded by an instruction in writing and two practice cases. After each case the subject had to mention the most probable hypothesis on the basis of the information provided. For this he was given 15 seconds per case. The answers were recorded on audiotape.

The criterion adopted for correctness of the diagnosis was the patient's actual diagnosis; two independent raters, both physicians, compared the hypotheses as expressed by the subjects with these actual diagnoses (inter-rater agreement 94 per cent). 


\section{Results}

A two-way analysis of variance on the number of correct hypotheses was carried out with subject group and way of case presentation as independent variables. The results show significant interaction between subject group and way of case presentation $(F(1,28)=4.56 ; p=.042)$. Only in the GP group the diagnostic performance was shown to be affected by the availability of contextual information.

In this group an increase in the mean number of correct hypotheses (5.6 to 9.9) was found by presenting complaints together with the portraits and medical cards of the patients $(F(1,14)=8.41 ; p=.012)$. In the knowledgeable, but inexperienced group no such effect was observed (means; 3.4 and $4.6 ; F(1,14)=2.59 ; p=1.30$ ), suggesting that the accuracy of their diagnostic hypotheses is not enhanced by the availability of contextual information.

A further finding is that GPs also have a better idea about what could be wrong given the complaint only: $F(1,14)=6.79 ; p=.021$.

Discussion

The results of this study show that experienced GPs', compared to 'inexperienced' graduates, generate better diagnostic hypotheses because they interprete contextual information in a more effective way. In our view this finding and also the fact that experienced GPS' produced better diagnostic hypotheses given the complaint only, are an effect of differences in knowledge structure. Because of extensive contacts with patients in daily practise GP' develop a knowledge base wich is activated more easily by information about the patient's context. This does not nessecarily mean that experienced GPs' make better estimates about the prior probability of certain diseases given the concise information we presented them. 


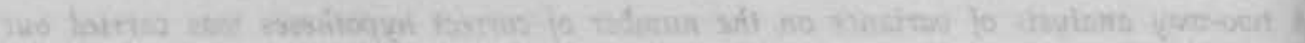

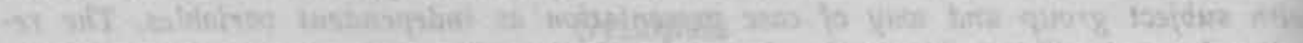

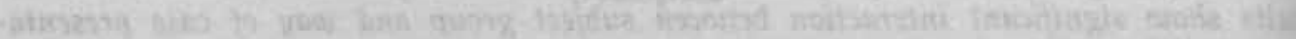
carth (I)

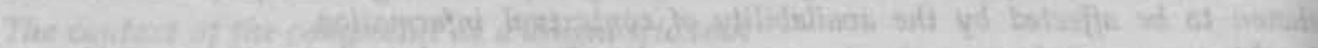

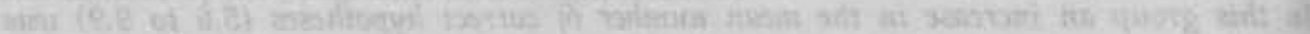

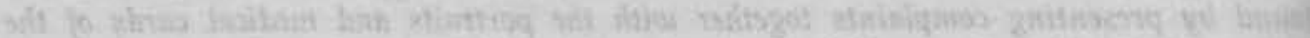

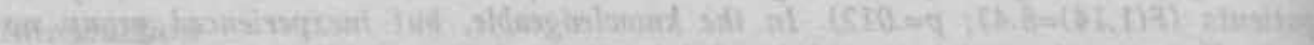

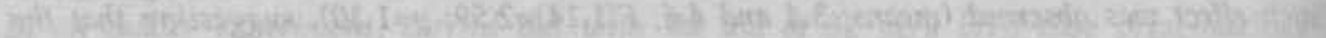

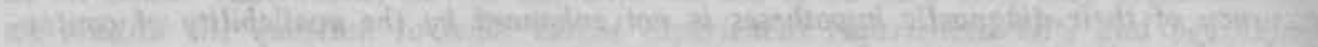

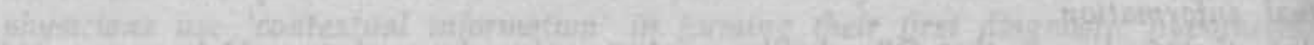

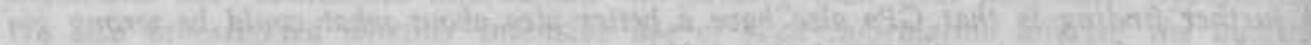

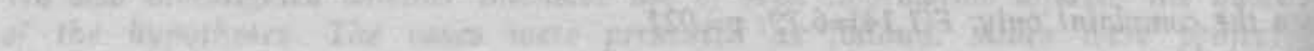

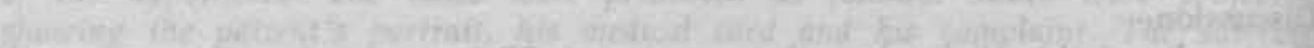

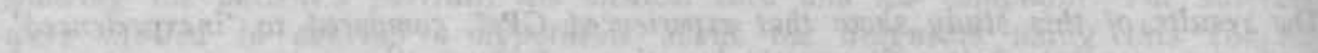

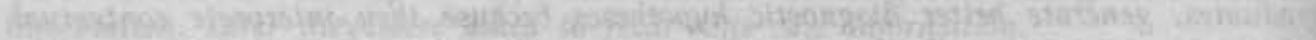

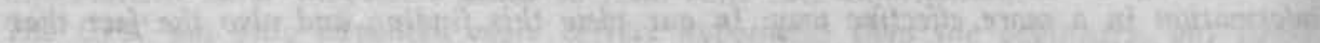
ufloc-4

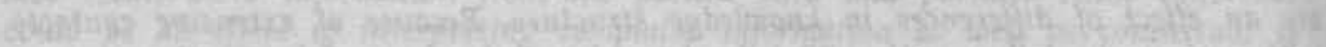

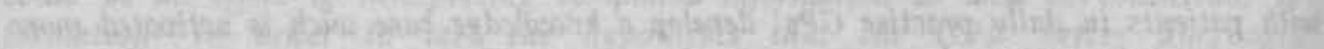

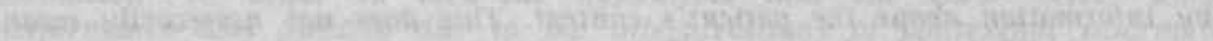

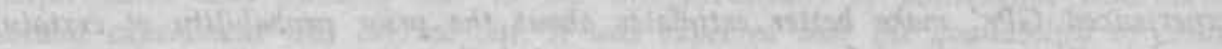

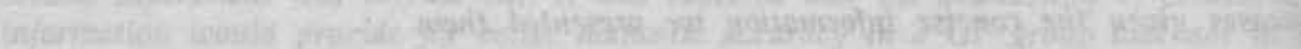

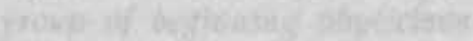

Distachexe

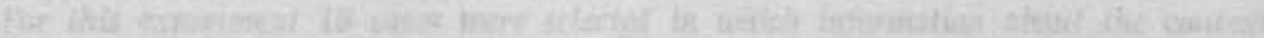

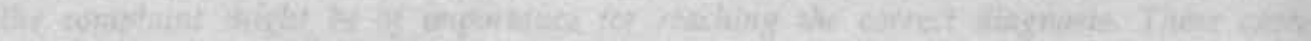

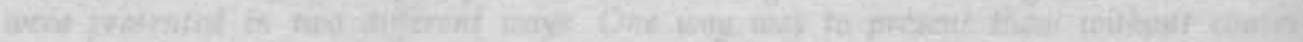

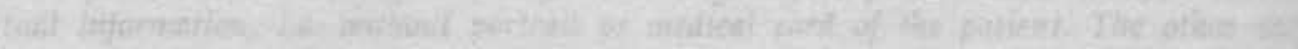

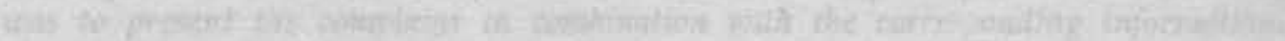

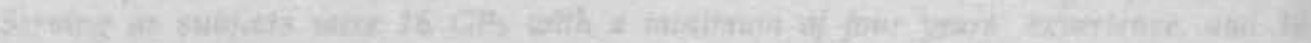

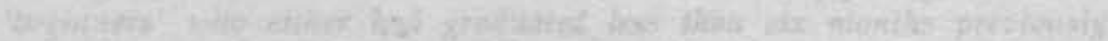

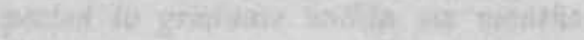

Whe cuser

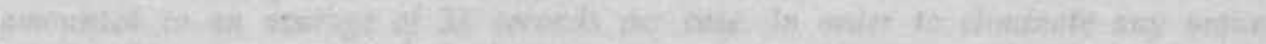

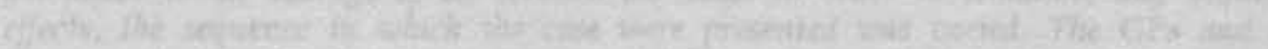

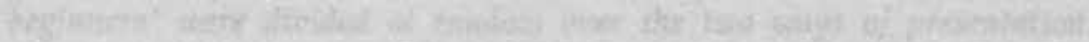

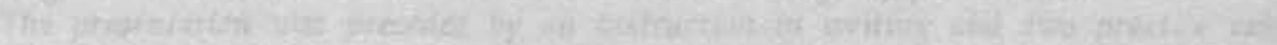

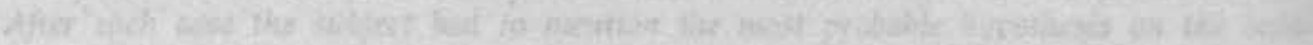

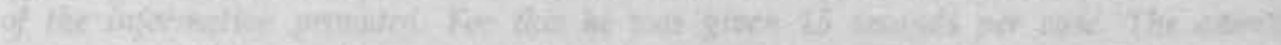

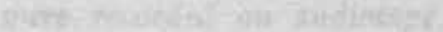

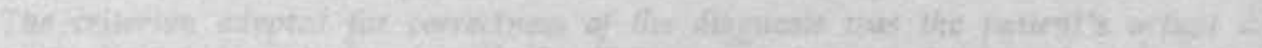

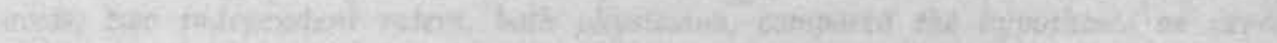

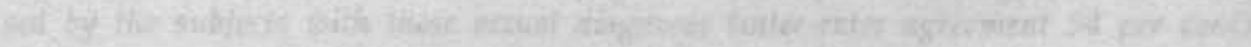




\section{HOOFDSTUK 4}

\section{DE INVLOED VAN ERVARING OP DIAGNOSTISCHE PRESTATIES VAN HUISARTSEN}

Eerder verschenen als:

Hofstra, M.L., Hobus, P.P.M., Boshuizen, H.P.A., Schmidt, H.G. (1988). De invloed van ervaring op diagnostische prestaties van huisartsen. Huisarts en Wetenschap, 31, 282- 284. 


\section{Samenvatting}

Zijn ervaren huisartsen beter dan onervaren huisartsen? In de literatuur worden een aantal onderzoeken beschreven waaruit zeker geen eenduidig verband blijkt tussen het aantal jaren praktijkervaring van artsen en de kwaliteit van hun handelen. In deze onderzoeken is met name het diagnostisch proces onderzocht; aan de kwaliteit van de diagnostiek werd nauwelijks aandacht besteed.

Besproken wordt een eigen onderzoek onder 34 Nederlandse huisartsen naar het verband tussen ervaring en het genereren van correcte diagnostische hypothesen. De gebruikte onderzoeksmethode simuleert de vroege fase van consulten door middel van diapresentaties. De resultaten laten een positief, nagenoeg rechtlijnig, verband zien tussen ervaring en het aantal correcte hypothesen, met andere woorden: hoe ervarener de huisarts, hoe beter de diagnostische prestaties. Dit onderzoeksresultaat lijkt meer in overeenstemming met de verwachting dan de resultaten uit eerder onderzoek. Daarnaast geeft de gehanteerde methode inzicht in factoren die deel uitmaken van aan ervaring gerelateerde bekwaamheid. 


\section{Inleiding}

Algemeen wordt aangenomen dat ervaren artsen betere artsen zijn dan onervaren artsen. Zoals Gerritsma en Smal (1982) schreven: " Het begrip "ervaren clinicus" is geassocieerd met een grotere bekwaamheid".

Maar wanneer is een arts ervaren en waaruit bestaat dan deze grotere bekwaamheid? Hoewel de geciteerde zinsnede doet vermoeden, dat de arts beter wordt naarmate zijn of haar ervaring toeneemt, ondersteunen een aantal op dit terrein verrichte onderzoekingen deze veronderstelling niet.

Rhee (1976) en Sanazaro (1985) presenteren resultaten van onderzoek onder artsen van diverse specialismen, waaruit blijkt dat het langer beoefenen van het vak niet persé meer kennis en grotere bekwaamheid oplevert. $\mathrm{Zij}$ verwijzen daarbij tevens naar onderzoekingen waarin soortgelijke bevindingen naar voren komen (Berwick., Fineberg \& Weinstein, 1981; Meskauskas, \& Webster, 1975; Peterson, Andrews, Spain \& Greenberg, 1956; Stolley, Becker, Lasagna, McEvilla \& Sloane, 1972; Vandewater \& Kraus, 1973). Rhee vindt een omgekeerd U-vormige relatie tussen ervaring en prestaties op diagnostisch en therapeutisch vlak met de top tussen zes en vijftien jaar ervaring. Sanazaro vindt zelfs een inverse relatie tussen ervaring en genoemde prestaties, oftewel: jongere artsen zouden het vak beter uitoefenen dan oudere artsen.

Wanneer wij ons beperken tot de diagnostiek, dan leert een nadere beschouwing van de gerefereerde literatuur dat voornamelijk aandacht besteed is aan de mate waarin een arts zijn diagnose onderbouwt (Peterson, Andrews, Spain \& Greenberg, 1956; Rhee, 1976; Sanazaro \& Worth, 1985). Dit wordt afgemeten aan normen die door een panel van vooraanstaande collegae opgesteld zijn. Opvallend in deze studies is dat er gekeken wordt naar het aantal juist geachte handelingen (anamnese, lichamelijk onderzoek, laboratoriumaanvragen, etc.) gegeven bepaalde diagnosen, en niet naar de mate waarin artsen überhaupt correcte diagnosen stellen. De onderzochte handelingen werden geregistreerd door middel van medical record onderzoek (Rhee, 1976; Sanazaro \& Worth, 1985) of observaties in de praktijk (Peterson, Andrews, Spain \& Greenberg, 1956). Neufeld en Norman (1985) menen dat men in dit soort onderzoek vraagtekens kan stellen bij de validiteit van het verzameld materiaal. $\mathrm{Zij}$ bedoelen daarmee dat men met de gekozen procedures in feite gedrag mest dat de werkelijkheid slechts ten dele benadert. Dit verschijnsel kan een gedeeltelijke verklaring zijn voor de gevonden, contraïntuitieve, verbanden. Het onderzoek van Ridderikhoff (1986) komt wat meer tegemoet aan de genoemde bezwaren. Hij presenteerde een aantal gestandaardiseerde patiëntensimulaties aan 60 huisartsen en 8 internisten, die hij indeelde in groepen met 0-6 jaar, 6-20 jaar en meer dan 20 jaar ervaring. Hierbij werd een groot aantal variabelen met betrekking tot het diagnostisch handelen gemeten. De onderzoeksresultaten laten weinig verschil zien tussen de drie groepen in het aantal door de artsen gestelde anamnestische vragen, de benodigde consulttijd, het aantal gegenereerde diagnostische hypothesen en het soort denkstrategieën. Helaas kon ook in dit onderzoek geen uitspraak gedaan worden omtrent de kwaliteit van diagnostiek in termen van het aantal geproduceerde 
correcte diagnosen. Dit leidt tot de vraag of ervaring bij (huis-) artsen wel afgemeten kan worden aan een aantal (al dan niet door anderen juist geachte) handelingen? Feitelijk wordt met het meten van een aantal handelingen slechts het proces dat naar een diagnose leidt beoordeeld en niet het produkt zelf. De reden dat in veel onderzoek naar diagnostische bekwaamheid geen vooruitgang of soms zelfs een achteruitgang wordt geobserveerd naarmate een arts meer ervarener wordt, kan daarom gelegen zijn in het gegeven dat men met de gebruikte variabelen te zeer het diagnostisch proces meet in plaats van kwalitatief, inhoudelijke aspecten (Barrows, Norman, Neufeld, \& Feightner, 1982; Elstein, Shulman \& Sprafka, 1978).

De implicatie van deze analyse is dat, wil men effecten van ervaring op bekwaamheid onderzoeken, het in onze ogen noodzakelijk is de aandacht meer te richten op inhoudelijke aspecten van de diagnostiek, zoals bijvoorbeeld de kwaliteit van diagnostische hypothesen die een huisarts al vroeg in een consult genereert (Barrows, Norman, Neufeld, \& Feightner, 1982). In het hier beschreven onderzoek, is op experimentele wijze onderzocht wat de relatie is tussen het aantal praktijkjaren en de kwaliteit van vroege diagnostische hypothesen. Het belang hiervan is gelegen in de constatering dat de accuraatheid van deze vroege hypothesen sterke voorspellende waarde heeft voor de juistheid van de uiteindelijke diagnose (Elstein, Shulman \& Sprafka, 1978).

\section{Methoden}

Hobus et al. (1987) ontwierpen een experiment waarin de vroegste fase van een consult wordt gesimuleerd door een diapresentatie, waarna de huisarts om de op dat moment meest waarschijnlijke diagnose wordt gevraagd. Op deze wijze kan men de diagnostische prestaties van artsen op een groot aantal casus op efficiënte wijze bestuderen.

\section{Materiaal}

Gebruik werd gemaakt van casusmateriaal zoals door Hobus et al (1987) is ontwikkeld. Dit materiaal bevat casus, gebaseerd op authentieke patiënten-gegevens uit een bij de Rijksuniversiteit Limburg aanwezig bestand van huisartsencasuistiek. ${ }^{1}$ Voor dit experiment werden dezelfde 18 casus geselecteerd als beschreven in een vorig experiment (Hobus, Hofstra, Boshuizen, \& Schmidt, 1988). De aandoeningen die aan deze casus ten grondslag liggen betreffen alle tractus. De eerste fase van de consulten werd met behulp van dia's gesimuleerd. Daartoe werden per casus drie dia's gepresenteerd. De eerste dia toont het portret van de patiënt, de tweede de groene kaart met medische gegevens, en de derde dia vertoont een zin die de klacht verwoordt. Dit is als het ware een weergave van de volgende stappen in een consult: 1 . De patiënt komt binnen (portret) 2. de arts bekijkt de voorgeschiedenis en andere gegevens van de patiënt (groene kaart) 3. de patiënt uit zijn/haar klacht. Na elke serie van 3 dia's, tezamen een casus vormend, komt een blanco dia in beeld.

\footnotetext{
${ }^{1}$ Met dank aan B.F Stalenhoef-Halling (gestorven op 28 november 1992) voor het bereidwillig
} ter beschikking stellen van dit bestand. 


\section{Proefpersonen}

Proefpersonen zijn 8 huisartsen uit noord-Nederland en 26 uit Limburg met tussen de 3 en 30 jaar praktijkervaring (gemiddeld: 12.7 jaar; S.D. 7.9). Van hen werken 8 part-time (minstens 50\%), de overigen werken full-time in de praktijk. Er zijn 6 huisartsen voor minimaal $10 \%$ van de werktijd verbonden aan een Huisartsen Instituut. De groep bestaat uit 6 vrouwen en 28 mannen. De proefpersonen zijn alleen geselecteerd op het hebben van ervaring; factoren als woonjplaats, geslacht en wijze van praktijkvoering worden niet van invloed geacht op die door ons onderzochte cognitieve processen.

\section{Afname- en scoringsprocedure}

Afname vindt individueel plaats. De 18 casus worden op een gestandaardiseerde wijze aan de proefpersonen gepresenteerd: d.w.z. met vaste presentatietijden per dia. Per casus is de gemiddelde presentatietijd 32 seconder. Met eventuele volgordeeffecten wordt rekening gehouden middels het systematisch wisselen van de casusvolgorde. $\mathrm{Na}$ een schriftelijke instructie en een tweetal oefencasus, volgt de feitelijke afname.

De opdracht na iedere casus is om, gegeven de informatie, de meest waarschijnlijke hypothese te noemen. De proefpersoon heeft hiervoor telkens 15 seconden ter beschikking. Antwoorden worden op audiocassetteband vastgelegd.

De juistheid van de genoemde hypotheses wordt als volgt vastgesteld: als criterium voor de juistheid is de authentieke diagnose van de patiënt genomen; twee onafhankelijke beoordelaars vergelijken de uitspraak van de proefpersoon met deze oorspronkelijke diagnose. De interbeoordelaarsovereenkomst bedraagt $94,4 \%$.

\section{Analyse}

Analyse van de resultaten vindt plaats door middel van een lineaire regressieanalyse met daarop aansluitend een polynomiale regressieanalyse. Hiermee wordt het verband onderzocht tussen het aantal juiste hypotheses en het aantal jaren praktijkervaring. Het verschil in diagnostische prestatie tussen ervaren en minder ervaren huisartsen wordt getoetst met behulp van een $t$-toets.

\section{Resultaten}

De 34 participerende huisartsen stelden minimaal 3 en maximaal 13 juiste diagnoses bij 18 casus. Wanneer het aantal juiste diagnoses wordt afgezet tegen het aantal jaren ervaring, ontstaat figuur 4.1. Elk punt vertegenwoordigt de prestatie van een proefpersoon; de getekende lijn is de lineaire regressielijn. Er blijkt een behoorlijk sterk verband te zijn tussen ervaring en het aantal juiste diagnoses: de correlatiecoëfficiënt bedraagt 0.69 . 


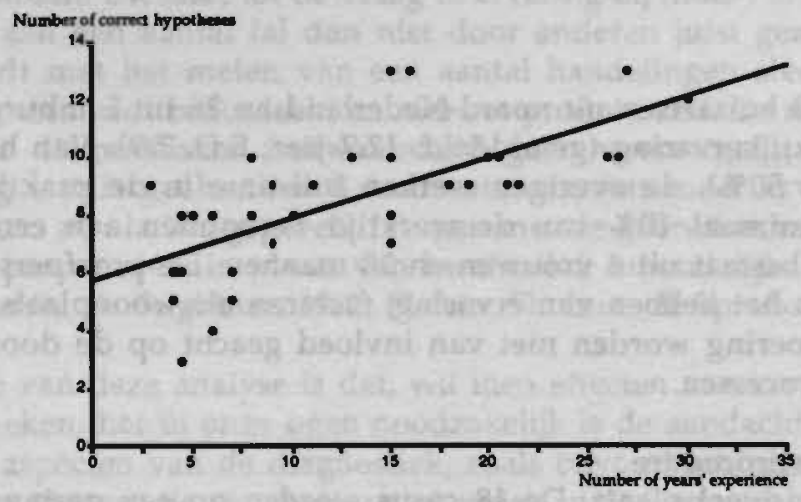

Figuur 4.1: Relatie tussen ervaring en diagnostische prestatie bij huisartsen ( $N=34$ ). Lineaire regressieanalyse -- Correlation between experience and diagnostic performance of $G P s(N=34)$. Linear regression analysis.

Dat betekent dat het aantal jaren ervaring van de huisarts $47 \%$ van de totale variantie in diagnostische prestatie verklaart. Om een eventueel kromlijnig verband, zoals dat in de geciteerde literatuur naar voren kwam, toe te staan, werd in aansluiting aan de lineaire regressieanalyse een polynomiale regressieanalyse van de 2 de orde uitgevoerd. Deze is afgebeeld in figuur 4.2.

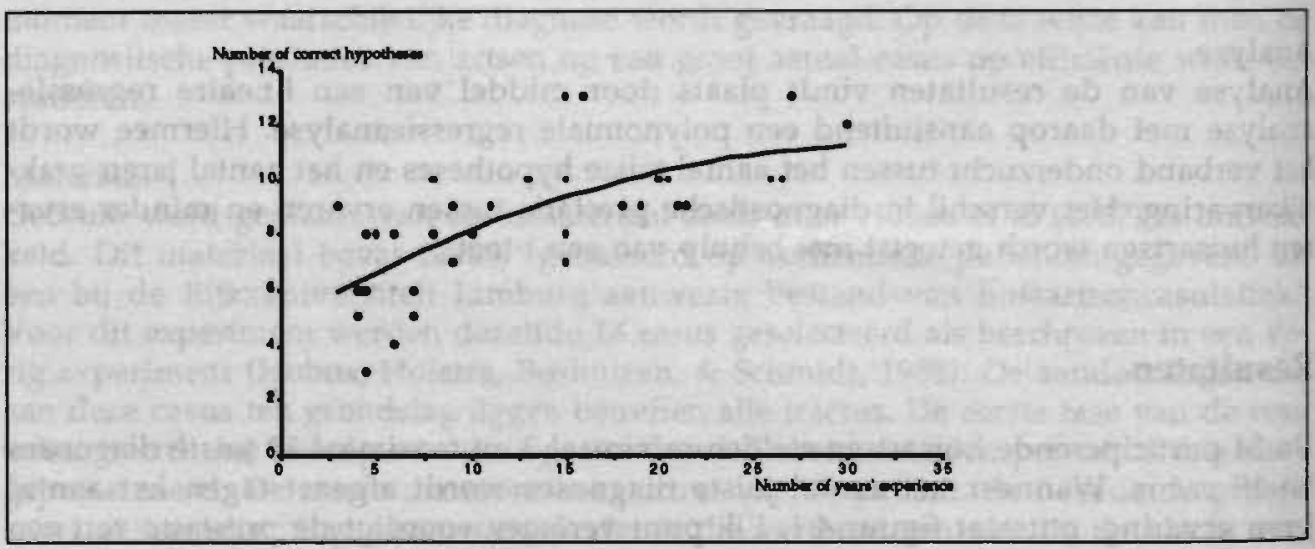

Figuur 4.2: Relatie tussen ervaring en diagnostische prestatie bij huisartsen $(N=34)$. Polynomiale regressieanalyse- Correlation between experience and diagnostic performance of GPs $(N=34)$. Polynomial regression analysis.

De verklaarde variantie in de scores van de deelnemende huisartsen in deze analyse verschilt niet noemenswaardig van die in de lineaire regressieanalyse $(49 \%)$. 
Vervolgens kan de groep proefpersonen in tweeën verdeeld worden, gezien hun onderlinge verschillen in ervaring. Men vergelijkt dan een groep jongere huisartsen (de 50\% artsen met de minste ervaringsjaren) met een groep oudere huisartsen (de 50\% artsen met de meeste ervaringsjaren). De scheidslijn tussen deze groepen valt dan bij 10 jaar ervaring. De gemiddelde score van de jongere huisartsen bedraagt 6.8 (SD 1.91) juiste diagnoses per 18 casus; de gemiddelde score van de oudere huisartsen is 10.1 (SD 1.75) juiste diagnoses. Dit verschil tussen de jongere en de oudere huisartsen is opmerkelijk en zeer significant ( $t$-value: $-5.148 ; p<.0001$ ).

\section{Beschouwing}

Getracht werd om door middel van onderzoek onder Nederlandse huisartsen thet verband te beschrijven tussen ervaring en kwaliteit van huisartsgeneeskundige: diagnostiek. Specifieke aandacht ging uit naar het genereren van vroege diagnostische hypothesen. Dit werd gedaan omdat een hypothese gestuurd verloop van de verdere diagnostiek een typisch kenmerk van huisartsgeneeskundig handelen is. Daarbij voorspelt de kwaliteit van eerste hypothesen in hoge mate de kwaliteit van de uiteindelijke diagnose en het op grond daarvan opgestelde behandelingsplan (Barrows, Norman, Neufeld, \& Feightner, 1982).

Gebruik werd gemaakt van een experimentele benadering waarbij de informatie en bestuderingstijden gestandaardiseerd en zoveel mogelijk overeenkomstig de werkelijkheid aangeboden werd.

Er werd, binnen de range van ervaringsjaren die de huisartsen in ons onderzoek representeerden (3-30), een nagenoeg rechtlijnig positief verband aangetroffen tussen het aantal jaren praktijkervaring, en het aantal juiste hypotheses. De meer ervaren huisartsen stelden een significant groter aantal juiste hypotheses dan de minder ervarenen. Een omgekeerd evenredig, of een omgekeerd U-vormig verband tussen ervaring en diagnostische bekwaamheid, zoals elders in onderzoek naar voren kwam, is door ons niet gevonden. Een mogelijke verklaring daarvoor is het verschil in de soort onderzochte variabelen: proces- versus inhoudelijke variabelen.

De vraag, waaruit verklaard kan worden dat met toenemende ervaring meer accurate hypothesen gegenereerd worden, is beantwoord in een vorig artikel in dit tijdschrift (Hobus, Hofstra, Boshuizen, \& Schmidt, 1988). In dat onderzoek werden met behulp van dezelfde simulatiemethode en dezelfde casuïstiek huisartsen met basisartsen vergeleken. Daarin werd aangetoond dat de kwaliteit van vroege diagnostische hypothesen bij ervaren huisartsen beter is dan bij basisartsen doordat zij op profijtelijke wijze gebruik weten te maken van gegevens uit de context waarin de klacht van de patiënt ligt ingebed. (Dit zijn gegevens die impliciet voorhanden zijn zoals leeftijd, geslacht, medische voorgeschiedenis, medicijngebruik en beroep.) Deze simulatie blijkt vervolgens ook zeer bruikbaar te zijn om effecten van ervaring bij huisartsen op diagnostische prestatie aan te tonen. De toenemende bekwaamheid in het gebruik van contextuele informatie in de vroege fase van een consult kan gezien worden als een effect van ervaring. Met andere woorden: door hun grote praktische ervaring met patienten hebben oudere huisartsen geleerd op 
effectieve wijze om te gaan met contextuele informatie e.g. informatie afkomstig uit de context van de klacht.

Dat artsen leren van ervaring wordt weleens betwijfeld (Brehmer, 1980; Ridderikhoff, 1986). De auteurs schrijven dit toe aan de beperkte capaciteit van mensen om, statistisch gezien, juiste gevolgtrekkingen uit waarnemingen te maken. Daarom is men geneigt incorrecte probabilistische relaties tussen variabelen te leggen. Dit impliceert geenszins dat artsen helemaal niets leren van hun dagelijkse ervaringen. Het produkt van dit leerproces uit zich in ons onderzoek in een steeds toenemende bekwaamheid ten aanzien van het gebruik van contextuele informatie resulterend in kwalitatief betere hypotheses.

Uiteraard betekent het gevonden sterke verband tussen ervaring en prestatie niet zonder meer dat onervaren artsen slechtere artsen zijn. Men moet zich realiseren dat alleen prestaties gedurende de eerste momenten van een patiëntcontact onderzocht zijn. Het is zeer wel mogelijk dat onervaren artsen hun relatieve achterstand in diagnostiserend vermogen in het allereerste begin van het consult compenseren door bijvoorbeeld een uitgebreidere anamnese, het vaker terugbestellen van een patiënt, of hogere verwijzingspercentages, zodat uiteindelijk ook zij de juiste diagnose kunnen formuleren. Deze redenering voortzettend, betekent dit dat deze compenserende mechanismen minder optreden naarmate men meer ervaren wordt, omdat men leert efficiënter om te gaan met de impliciete, contextuele informatie. Het efficiënter omgaan met dergelijke informatie zou kunnen betekenen dat minder handelingen uitgevoerd worden, zodat schijnbaar de kwaliteit van de diagnostiek afneemt. Dit zou de omgekeerd U-vormige en inverse relaties kunnen verklaren die anderen vonden.

Tenslotte: het is frappant te zien hoe de oudere huisartsen, met slechts zeer summiere informatie over een patiënt en onder een zekere tijdsdruk, reeds in $56.1 \%$ van de gevallen een correcte diagnose opperen. Dit moet het resultaat van een door de jaren aangescherpt kennisgebruik zijn. Vele tienduizenden patiëntencontacten liggen ten grondslag aan het perfectioneren van een dergelijk mechanisme. De basis hiervan kan echter al tijdens de opleiding tot (huis)arts gelegd worden door te wijzen op het belang van contextuele gegevens voor de diagnostiek.

\section{Referenties}

Barrows, H. S., Norman, G. R., Neufeld, V. R. \& Feightner, J. W. (1982). The clinical reasoning of randomly selected physicians in general medical practice. Clinical \& Investigative Medicine, 5 , 49-55.

Berwick, D.M., Fineberg, H.V. \& Weinstein, M.C. (1981). When doctors meet numbers. The American Journal of Medicine, 71, 991-998.

Brehmer, B. (1980). In one word: not from experience. Acta Psychologica, 45, 223-241.

Elstein, A.S., Shulman, L.S. \& Sprafka S.A. (1978). Medical Problem Solving: An Analysis of Clinical Reasoning. Cambridge, Mass.: Harvard University Press. 
Gerritsma, J.G.M. \& Smal, J.A. (1982). De werkwijze van huisarts en internist. Utrecht: Wetenschappelijke Uitgeverij Bunge.

Hobus, P. P. M., Schmidt, H. G., Boshuizen, H. P. A. \& Patel, V. L. (1987). Contextual factors in the activation of first diagnostic hypotheses: Expert-novice differences. Medical Education, 21, 471 476.

Hobus, P.P.M., Hofstra, M.L., Boshuizen, H.P.A. \& Schmidt, H.G. (1988). De context van de klacht als diagnosticum. Huisarts en Wetenschap, 31, 261 - 263, 267.

Meskauskas, J.A. \& Webster, G.D. (1975). The american board of internal medicine recertification examination: process and results. Annals of Internal Medicine, 82, 577-581.

Neufeld, V.R. \& Norman, G.R. (1985). Assessing clinical competence. Springer series on Medical Education. New York: Springer Publishing Company.

Peterson, O., Andrews, L.P., Spain, R.S. \& Greenberg, B.G. (1956). An analytical study of North Carolina general practice: 1953-1954. Journal of Medical Education, 31, Part 2, 1-165.

Rhee, S. (1976). Factors determining the quality of physician performance in patiënt care. Med ical Care, 14, 733-750.

Ridderikhoff, C. (1986).Decision-making strategies in the general practice. (Academisch proefschrift, Erasmus Universiteit Rotterdam) Rotterdam.

Sanazaro, P.J. \& Worth, R.M. (1985). Measuring clinical performance of individual internists in office and hospital practice. Med Care, 23, 1097-1114.

Stolley, P.D., Becker, M.H., Lasagna, L., McEvilla, J.D. \& Sloane, L.M. (1972). The relationship between physician characteristics and prescribing appropiateness. Medical Care, 10, 17-28.

Vandewater, S.L. \& Kraus, A.S. (1973). Family physician anesthetists: continuing education, observations, evaluation. Canadian Medical Association Journal, 109, 1228-1231. 


\section{Synopsis}

The influence of experience on GPs' diagnostic performance.

\section{Introduction}

It is generally assumed that experienced physicians are better physicians than inexperienced ones, but the literature fails to support this view (Berwick, Fineberg, \& Weinstein, 1981; Meskauskas \& Webster, 1975; Peterson, Andrews, Spain \& Greenberg, 1956; Rhee, 1976; Sanazaro \& Worth, 1985; Stolley, Becker, Lasagna, McEvilla \& Sloane, 1972; Vandewater \& Kraus, 1973) It is however a noticeable feature of the studies reported, that they focused on the number of actions in consultation considered correct, rather than on the extent to which GPS make correct diagnoses in the first place. It may be necessary to pay more attention to the substantive of the diagnostics, such as the quality of the diagnostic hypotheses wich the GP already evolves early in the consultation. The present report concerns an experimental study of the correlation of the number of years in practice with the quality of early diagnostic hypotheses.

\section{Method}

The test subjects were 8 GPs from the norther part of the Netherlands, and 26 from the southern province of Limburg, who had from three to thirty years' experience in practice (mean 12.7 years; SD 7.9). The only criterion of selection was experience; factors such as place of residence, sex and type of practice were considered irrelevant to the cognitive processes investigated. The study was carried out with the aid of the same case material as the experiment published in the previous issue of Huisarts en. Wetenschap (Hobus, Hofstra, Boshuizen \& Schmidt, 1988). In the present study all cases consisted of three slides, showing a portrait, a patient chart and a complaint, thus representing the earliest phase of a consultation.

\section{Results}

The 34 participating GPs made at least 3 and at most 13 correct diagnoses in the total of 18 cases. In figure 4.1 the number of correct diagnoses is plotted against the number of years of experience. Each dot represents the performance of one test subject; the drawn line is the linear regression line. A strong correlation is found to exist between experience and the number of correct diagnoses: the correlation coefficient is 0.69. This means that a GP's number of years of experience explains 47 per cent of the total variance in diagnostic performance. Subsequently, in order to bring out a possible curoed line correlation, a polynomimial regression analysis of the second order was done (figure 4.2 ). The explained variance in the scores of the paticipating GPs in this analysis does not differ appreciably from that in the linear regression analysis (49 per cent).

The group can be divided into two, on the basis of the difference in experience: the younger GPs (the 50 per cent with the least number of years of experience) and the older GPs (the 50 per cent GPs with the most years of experience). The dividing line between the two groups lies at 10 years' experience. The mean score per 18 cases of 
the younger GPS amounts to 6.8 (SD 1.91), that of older GPs to 10.1 (SD 1.75).This difference is highly significant ( $t$ value: -5.148 ; $p<.0001$ ).

\section{Discussion}

The method of consultation representation as described by Hobus at al. was already proved to establish a difference in diagnostic skill between experienced GPs and inexperienced graduate medical students (Hobus, Schmidt, Boshuizen \& Patel, 1987; Hobus, Hofstra, Boshuizen \& Schmidt, 1988) Also these studies demonstrated that accurate hypothesis generation is related to the use of socalled "contextual information. ${ }^{\text {" }}$

In the present study the same method leads to a further differentation between GPs' of different years of experience. The observed strong correlation between experience and performance therefore means that ability to select contextual information that is relevant to a patient's diagnosis increases even after many years of experience in daily practise. Of course it does not mean simply that inexperienced GPs are worse GPS. It should be kept in mind that this study was concerned only with performance during the earliest moments of a consultation. It is quite possible that inexperienced GPs make up for their arrears in diagnostic skill in the earliest phase of the consultation by, for instance, a more extensive anamnesis, by having patients come back more often or by more referrals, so that they, also, in the final instance, can make the correct diagnosis.

\footnotetext{
${ }^{1}$ Contextual information is information about the patient not necessarily related to the presentt complaint. This information concerns the patients' sex, age, profession, risk behavior, previous diseases or operations and medication.
} 


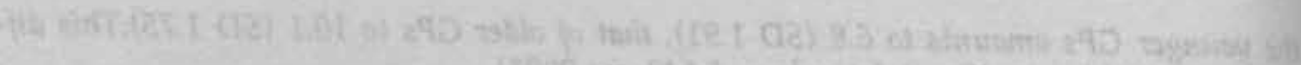

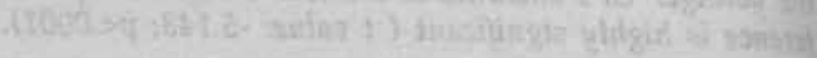

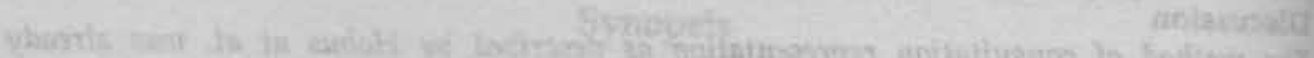

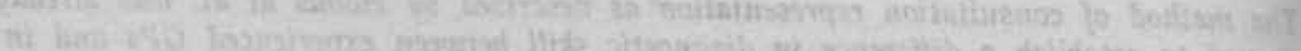

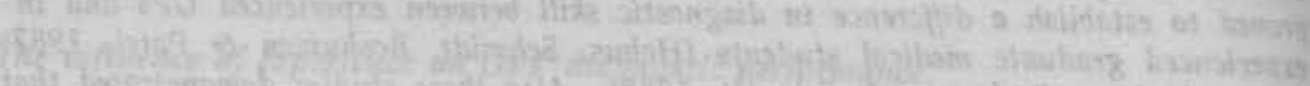

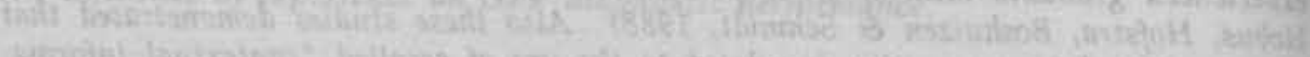

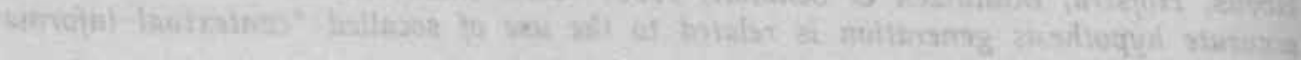

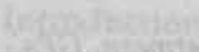

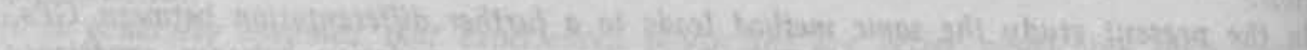

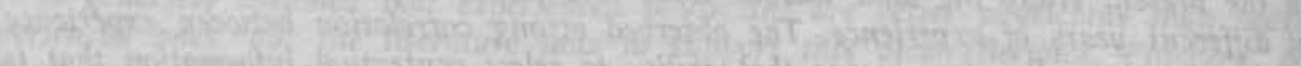

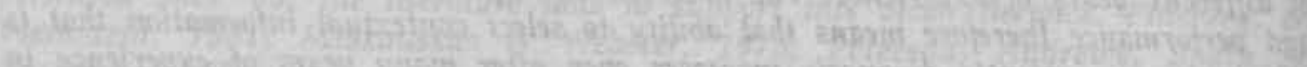

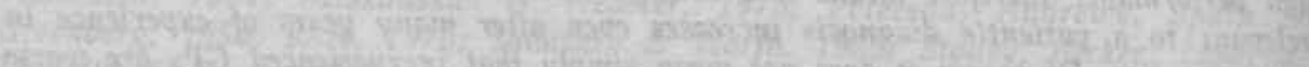

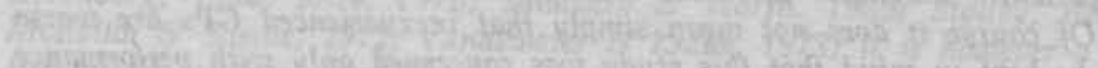

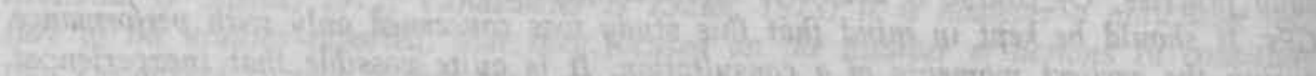

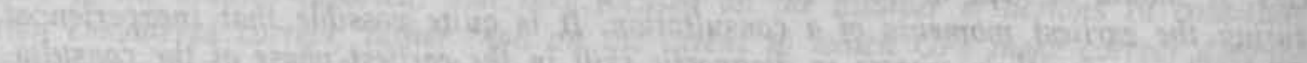

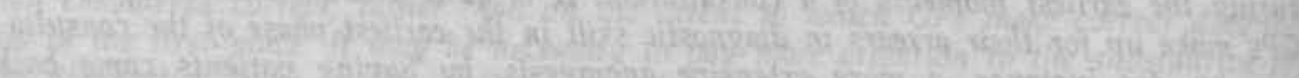
L.

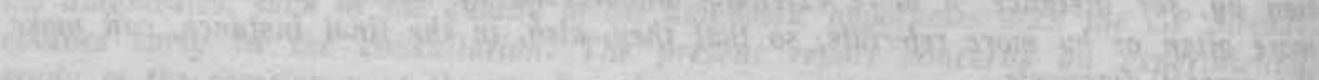

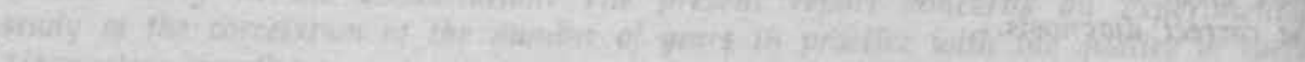

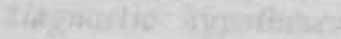

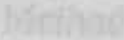

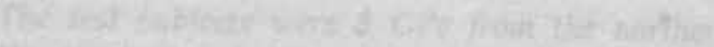

W. Wons

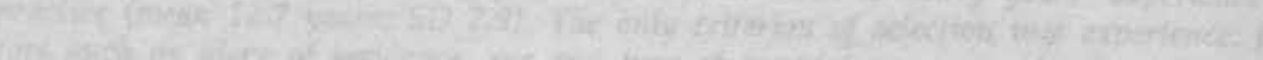

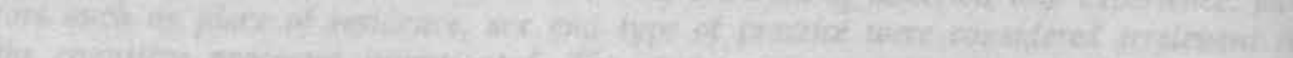

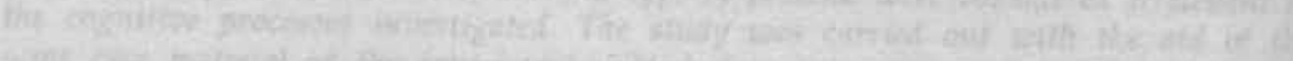

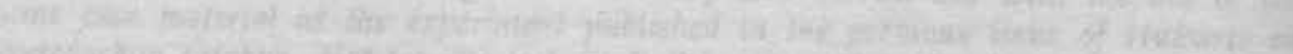

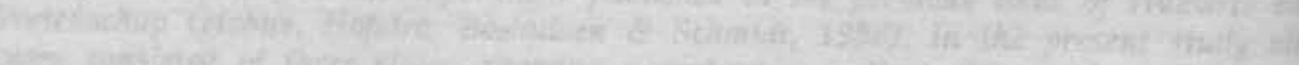

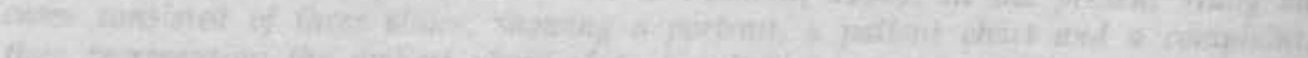

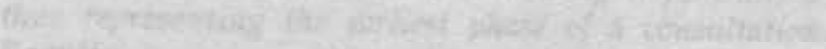

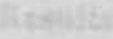

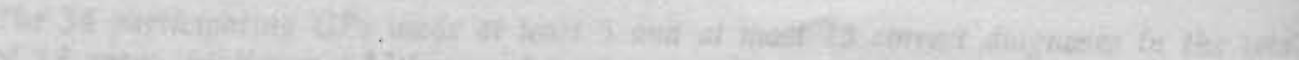
6. The

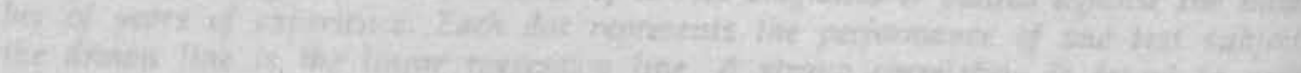

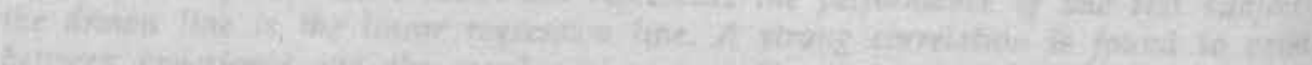

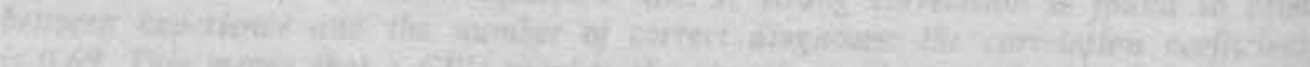

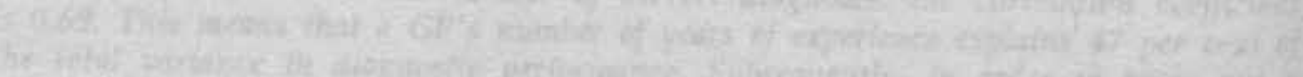

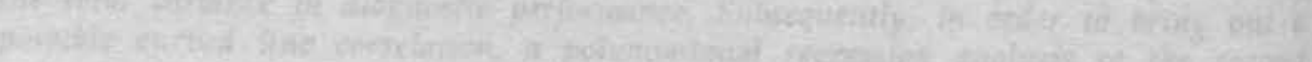

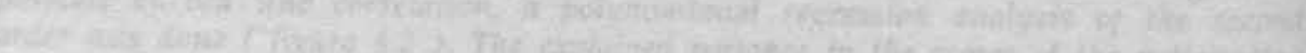
Q

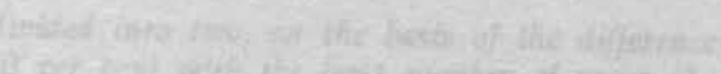

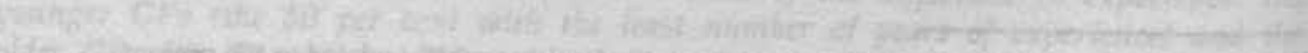

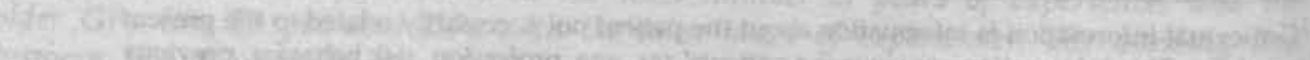

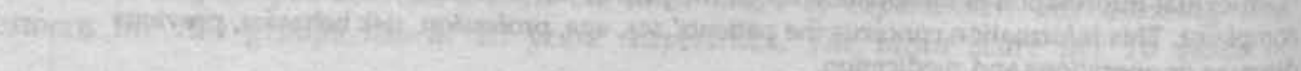

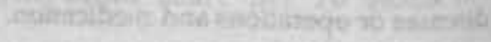




\section{HOOFDSTUK 5}

\section{WHAT CAUSES EARLY DIAGNOSTIC HYPOTHESES TO BE ACTIVATED: CONTEXT OR COMPLAINT?}

Een verkorte versie is gepubliceerd als:

Hobus, P.P.M., Boshuizen, \& H.P.A., Schmidt, H.G. (1991, april) Expert-novice differences in the role of contextual factors in early medical diagnosis. Paper presented at the Annual Meeting of the American Educational Research Association. Chicago. 


\section{Summary}

Preoious studies have shown that experts are better able to use information about the patient's context (e.8., age, sex or preoious diseases) in order to generate fruitful hypotheses about a patient's disease than novice physicians are able to. This paper investigates the theory that different knowledge structures underlie these findings. Generally, it was found that experts' disease knowledge is more refined and enriched than novices'. Experts' knowledge structure apparently contain more context aspects. Furthermore, analyses also demonstrated that knowledge accessibility is not identical for every type of contextual information.

During the early diagnostic stage, medical experts use information about the context of the patient, such as age, sex, profession, previous diseases, medical therapy etc. Therefore they generate better hypotheses than novice physicians. Although novices have studied epidemiological aspects of diseases like incidence rates, risk factors etc, they apparently are unable to utilize contextual information as fruitfully. It could be their knowledge in this respect is only rudimentary. Or maybe, at graduation knowledge structures are only activated by a patient's complaint or signs and symptoms. Later, through medical experience this role can also be taken by contextual information. In order to study these two alternative explanations an experiment was designed in which presentation order of contextual information and the patient's complaint was varied. Expert-novice differences in diagnostic accuracy and recall show no differential effect of presentation order reversal. Therefore knowledge enrichment and refinement seems to be the major factor in developing expertise. However, further analyses demonstrated knowledge accessibility is not identical for every type of contextual information. 


\section{Introduction}

Research on medical expertise has shown that very early in an encounter physicians develop hypotheses about what is wrong with a patient (Barrows, Norman, Neufeld \& Feightner, 1982; Elstein, Shulman \& Sprafka 1978). In two experiments, Hobus and his colleagues (Hobus, Schmidt, Boshuizen \& Patel, 1987; Hobus, Hofstra, Boshuizen \& Schmidt, 1988) demonstrated that accurate hypothesis generation is related to the use of what they call "contextual information". Contextual information is information about the patient not necessarily relatted to the present complaint. This information concerns the patients' sex, age, profession, risk behavior, previous diseases or operations and medication. The finding that such information appears to influence diagnostic performance, might explain the speed with which first diagnosis related thoughts appear in the mind of a physician, and is probably related to what other authors have called intuitive reasoning (Berne, 1977; Style, 1979; Snoek, 1989). However, how exactly contextual information is used early in the encounter is not clear. There seem to be several possibilities. A family physician who knows his patient for many years, may be reminded of previous experiences with a certain patient when this patient enters the consultation room. These memories might activate tentative hypotheses about possible disorders in this patient even before the complaint is presented. The complaint itself can further confirm or falsify these hypotheses. For instance, the entrance of a persion, known as a heavy cigaret smoker who has just recovered from a serious myocardial infarction may lead his doctor already to the generation of cardiovascular hypotheses like "heart failure" or "angina pectoris" even before the patient complains about shortness of breath. By contrast, the physician might see his patient without preconceived ideas about the nature of the problem to be presented until he has heard the complaint. Maybe the complaint 'Doctor, I can't get enough air when I climb my stairs to the first floor', causes the physician to think of heart failure and angina pectoris whereafter these hypotheses are confirmed by the already known fact that the patient has suffered from earlier myocardial damage. In the latter case, contextual information does not trigger the activation of early hypotheses, but the complaint (or some other finding) does. Contextual information may than be activated post hoc to scan for relevant items in the light of the complaint. A third possibility is that both processes are active in the production of diagnostic hypotheses. In summary three possible events seem to be likely: 1: Early diagnostic hypotheses may be triggered by contextual information per se even before the complaint is presented. 2: The complaint may activatie hypotheses which are subsequently tested against relevant contextual knowledge, and 3: A combination of 1 and 2. Purpose of the present study is to test these explanations in physicians encountereci in early diagnosis.

One of the assumptions underlying the present study is that diagnostic reasoning is a knowledge-based activity and that diagnostic performance largely depends on the way knowledge is organized in memory (Brandsford, Sherwood, Veye \& Rieser, 1986). The very use of contextual information will therefore primarily be an effect of 
the way disease-knowledge is organized. An interesting theory in this respect has been developed by Schmidt and others (Schmidt, Boshuizen \& Hobus, 1988; Schmidt, Norman \& Boshuizen, 1990). According to these authors the knowledge of medical subjects with practical experience is primarily script based. They assume that previous experiences with patients leave traces in episodic memory taking the form of so called illness scripts (see also Feltovich and Barrows, 1984). These scripts are the cognitive representations of diseases as they occur in human beings. Each script contains three general types of information characterizing the patient and his illness: Enabling conditions, Faults and Consequences. "Enabling Conditions" describe the characteristics of a patient that are associated with the development of an illness like old age, smoking, and long-term hypertension is associated with the development of a myocardial infarction for instance. Clearly most of the enabling conditions can be found in the contextual information about a patient. The "Fault" describes the major acting malfunction in the organism, atherosclerosis in this case. A fault in turn leads to "Consequences" which describe the signs and symptoms as expressed by the patient. In case of a myocardial atherosclerosis this could be: "pain on the chest", "shortness of breath" or "palpitations". A specific illness script is activated whenever the physician diagnosis a patient characterized by the script. In terms of this theory the three proposed explanations about the use of contextual information are as follows. First illness scripts could be activated by the available contextual information that corresponds to certain enabling conditions in the subject's knowledge base. The complaint further converges this set of scripts into a smaller one that also contain applicable consequences. The second explanation is that primarily those scripts whose consequences fit the patient's complaint are activated. Thereafter the enabling conditions in these scripts are filled in by some of the available contextual information. The third possibility assumes that both activation mechanisms operate simultaneous.

Yet, no indications can be found in this theory nor in literature in order to decide between the three possibilities. Not withstanding that, our own research suggests differences between expert and novice physicians regarding the kind of information that triggers script activation (Hobus et al. 1987, Hobus et al. 1988). In these two studies expert physicians made a more extensive and effective use of contextual information as compared to novice physicians. In one study (Hobus et al. 1987) experienced and novice family doctors were confronted with short and incomplete case histories presented on slides. Besides a slide on which the main complaint was presented (for instance:"Last day I have a stabbing pain in the middle of my back, it's so worse that sometimes I am fainting"), two other slides displayed the contextual information. One slide showed a portrait of the patient, enabling the subjects to deduce age and sex, a man who is about 78 years old for instance. The other slide displayed a patient chart containing information about profession, previous diseases, medication, previous consultations etc. Some of the information on the chart was of diagnostic value in relation in this case: blood pressure values (which were too high), measured at very irregular intervals (indicating bad patient compliance), information on his heavy smoking and the prevalence of heart and vessel disease in his family. This relevant information was mixed up with irrelevant information like that of a pneumonia in 1978 and some previous 
operations. Subjects were required to state a diagnosis given this limited information, Dissecting Aortic Aneurysm ${ }^{1}$ in this case. Expert physicians were able to accurately diagnose $38 \%$ of the 32 presented cases whereas the novice physicians diagnosed about $27 \%$ accurately. The authors attributed this difference in diagnostic performance to a differential use of the contextual information, because experts in addition, remembered $33 \%$ more of this information when asked to recall whatever they could remember of the patients presented. In particular, experts remembered more about the relevant contextual information. In the subsequent study (Hobus et al. 1988) experts' effective use of contextual information was shown more directly. Again expert and novice physicians were asked to state a diagnosis in respons to short cases presented on slides. However, in this experiment subjects were randornly assigned to one of two conditions. In one condition only complaints were presented, in the other, complaints were presented together with the patients' portraits and medical cards. Novice physicians, in both conditions performed the diagnostic task almost at the same level of accuracy $(20 \%$ and $31 \%$ correctly diagnosed cases). In contrast, diagnostic performance of the more experienced colleagues was heavily influenced by the presence of contextual information. When contextual information was presented together with the complaints, diagnostic performance improved to more than twice the performance of experts who read only complaints! ( $55 \%$ and $25 \%$ accurately diagnosed cases) These results suggest that experienced physicians are more fruitful in using contextual information than physicians with less practical experience. These latter mainly rely on complaint information. Therefore, script activation in novice physicians is unlikely to be triggered by contextual information as such. Or to put it the other way: these results suggest that expert's script activation is more often than novice's triggered by contextual information. To activate relevant scripts exclusively using contextual information, the existence of many refined illness-scripts that are rich in enabling conditions is essential. According to Schmidt and others (1990) the development of such a knowledge base can only be accomplished through many years of medical practise.

In order to investigate which kind of script activation is predominant and to test the hypothesis that expert script activation is more often than in novices triggered by contextual information, the following experiment was designed. Eighteen short cases were presented to expert- and novice-physicians. Like before each case was presented on three slides; two slides containing contextual information, on the other slide the complaint information was presented. Exposure time was standardized. Presentation order of the complaint and contextual information was varied. Half of the subjects first read complaint information, followed by contextual information. In the other group this presentation order was reversed.

In case script activation is triggered by complaint information, the first presentation order (complaint-context) will demand less cognitive effort than the second presentation order: Script activation is triggered by the complaint and some of the subsequent presented contextual information supports those parts of the script that

\footnotetext{
${ }^{1}$ Dissecting Aortic Aneurysm is a longitudinal splitting of the arterial wall; often a result of severe atherosclerotic degeneration and high blood pressure
} 
contain enabling conditions. No "unused" information has to be kept in mind Hence, the complaint-context presentation order may result in shorter reaction times. Furthermore subjects under this condition are expected to recall more relevant contextual information than colleagues in the context-complaint order because of more selective scanning in view of the triggered scripts (Anderson \& Reder, 1979). If however, contextual information itsélf is the main factor that triggers the activation of scripts, subjects are expected to process case information faster than their colleagues when contextual information is presented before the complaint is given. In this case, recall of relevant contextual information may not be influenced by case presentation order because complaint information only slightly affects focus of attention on this information.

Although the cognitive effort to process a case may differ in the two presentation orders, it is not sure wether this effect is that large as to influence diagnostic accuracy. From (cognitive) research in medical problem solving it is known that diagnostic performance primarily depends on the available knowledge (Boshuizen, 1989). Therefore, it is hard to predict whether script knowledge, although available, can only be accessed in one of the two presentation orders. If knowledge accessibility is the main factor, diagnostic accuracy will be better in the complaint-context order, provided scripts are exclusively triggered by the complaint. In contrast, when scripts are solely triggered by contextual information diagnostic accuracy will be better in the other presentation order. If knowledge availability is the most important factor that determines diagnostic performance, no effect of presentation order is expected.

Experts however, are expected to generate more accurate hypotheses than novices in both presentation orders because their scripts contain more knowledge about enabling conditions (Hobus et al. 1989). As has been outlined previously, experts' scripts are hypothesized to be more often activated by context than novices' scripts because the former are more refined and adjusted to the complex reality of medical practise. In addition experts just may have more illness scripts. (Schmidt et al. 1990). This leads to the prediction that experts' response times will be shorter than novices', especially when contextual information is given first. Finally an effect of case presentation order is expected on expert-novice differences in recall of contextual information. If contextual information is presented before the complaint, experts' recall will be more relevant and show traces of extensive processing (e.g. inferences).

\section{Method}

\section{Subjects}

Subjects were 32 physicians and graduate medical students. The expert group consisted of 16 family physicians who on the average had 14.7 years of experience in primary health care (range 6-29). Average age was 43.6 years (range 35-59). The nevices were 3 final year medical students who were about to graduate within 3 months and 13 physicians who graduated less than 6 months prior to the experiment. Their average age was 27.6 years (range $24-40$ ). 


\title{
Material
}

The stimulus material consisted of 18 cases selected from a large collection of casedescriptions of real patients available at the University of Limburg Medical School. Case histories were selected such that contextual information could play a facilitative role in correct complaint interpretation. The cases covered all organ systems. Each case was presented on three slides. They displayed the portrait of the patient, his or her medical card, and the presenting complaint. This complaint consisted of one or two sentences as expressed by the patient. For instance: "I have a cold fever for already two days long, doctor. I sometimes lie down shaking in my bed". The portrait ${ }^{1}$ and medical card provided the contextual information of the complaint. They contained information concerning the age and sex of the patient as well as his or her profession, past operations, medication use, hereditary disorders, smoking and drinking habits and notes on previous consultations. The information consisted of items relevant as well as irrelevant to the complaint at hand.

Slides were projected with a closed-box-slide projector. Because recall, as an important dependent variable, is also partly affected by the duration of information input, the exposure time of each slide was fixed. The picture of the patient's face was exposed for 4 seconds. Some patient charts and complaints contained more information than others. Therefore exposure-times of the charts varied from 11 to 42 seconds, and from 3 to 8 seconds for the complaint. They were established in several pilot studies with experts and novices. Thus, the contextual information was exposed to the subjects with a mean exposure time of 35.1 seconds.

\section{Procedure}

Subjects were randomly assigned to one of two conditions. In one condition the 18 stimulus cases were presented as follows. The first slide showed the complaint of the patient, the second the portrait, and the third the medical card. In the other condition the presentation order of case information was reversed. First the patient's portrait was shown, then the medical card, and finally the complaint. Between cases a black slide was projected for about 15 seconds to limit the subjects' maximum amount of processing time. During that interval the subject was requested to state a most likely preliminary diagnosis, given the information presented.

The following instruction was read to the subjects:

\begin{abstract}
"This experiment focuses on diagnostic hypotheses a physician already has in mind early in a diagnostic encounter. In order to investigate this, you are asked to judge a number of cases. The data of each case you'll see are quite incomplete. Hence, we realize that it will sometimes be difficult to state a diagnosis. Nevertheless, you are requested to state one diagnosis for each case, namely the one that you feel is the most likely at present. We want you to respond as quickly as possible. You will see 18 cases. Each case is presented on 3 slides with a portrait, a medical chart, or a complaint. They are exposed for a limited amount of time. After the third slide a black slide is exposed You may react as soon you think you know the most likely diagnosis."
\end{abstract}

\footnotetext{
${ }^{1}$ The portrait was presented to give case presentations more "face"-validity. As an information source it was supposed to convey the sex and age of the patient only. Other characteristics visible like facial expression and colour of the hair were not of diagnostic importance.
} 
In each condition, the 18 cases were presented in two series of 9 each. Presentationorder of the two series was varied systematically over subjects to compensate for possible recency effects in the recall. After a series was completed; each of the $9 \mathrm{com}$ plaints presented was read back to the subject, together with the tentative diagnosis the subject had generated. Subsequently the experimenter asked the subject to recall whatever he or she remembered from the case. All responses were given verbally and recorded on audiotape.

\section{Analysis}

\section{Response time}

The electric pulses that steered projection of case-slides were passed on to the audio tape recording the subjects responses. This procedure enabled us to measure the subjects' processing time for each case by way of Video Time Coding (according to SMPTE-EBU standards ${ }^{1}$ )

\section{Diagnostic accuracy}

Two independent judges compared the answers of the subjects with the actual diagnosis of the case. Interrater agreement was $92.1 \%$

\section{Recall}

A verbatim transcript was derived from the audiotaped responses. In order to measure the amount of contextual information recalled, the information on the paitient charts was segmented into information units. An information unit was defined as a statement containing one singular fact or idea (Schmidt, 1982). For instance the line: 'Knee complaints; artrosis?' in case number 4 (presented in figure 5.1) contains two propositions: The complaint: 'knee complaints' and the diagnosis: 'artrosis'. The portrait of the patient and birth-date on his chart were considered to contain two units of information: Sex and age. Furthermore, it was determined whether an proposition was relevant to the correct diagnosis or not ${ }^{2}$ (see the example below). The verbatim transcripts of the subjects' responses were then compared with the segmented case-information. The accuracy and completeness of information recalled was determined as follows: Of every unit recalled it was decided whether it could be considered literal, partial or inferential recall of an proposition; or as a summary of a part of the contextual information presented. One tally was given for each proposition recalled. In case of a summary a distinction was made as to whether it referred to the content or to the frequency aspect of the summarized information or to both. Two tallies were given when the summary referred to both frequency and content of a group of propositions; one tally was given when it referred to frequency or content only.

\footnotetext{
${ }^{1}$ In this procedure, the audio tapes containing slide-steering-pulses and subjects' answeres were transferred to videotapes. During video playing, every time when the first steering pulse of a case appeared, a parallel time clock started running. The video was stopped when a subject started uttering a tentative hypothesis. The parallel-clock stopped simultaneous and enabled us to record information processing times with an accuracy of one decimal second. We thank G.van Wunnik, for his collaboration.

2 This was done by two experienced medical judges in a consensus procedure
} 
In addition to the complaint and a portrait showing an older woman, the following patient chart was shown:

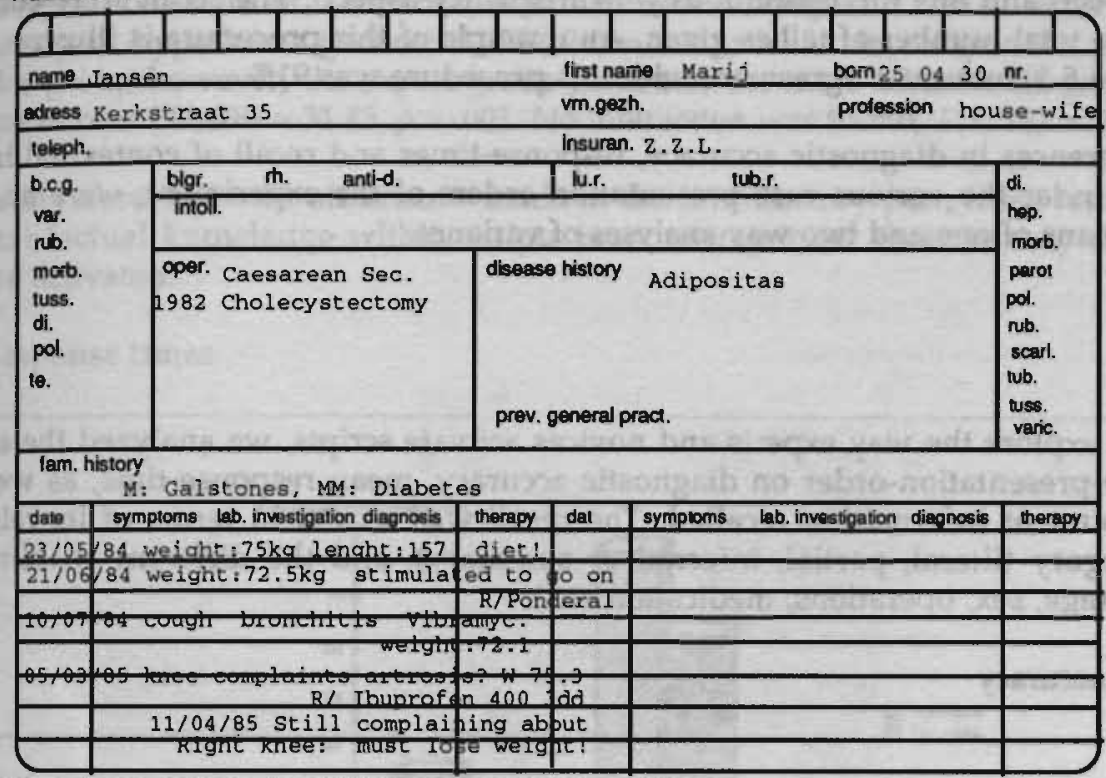

This chart contains the following relevant propositions:

(woman // born; 250430 // 1982 // disease history; Adipositas // fam history; MM: Diabetes // 23/05/84 // Weight: 75kg // Length: $157 / /$ Diet! // 21/06/84 // Weight: $72.5 \mathrm{~kg} / /$ stimulated to go on // R/ Ponderal // 10/07/84 // Weight: 72.1 // 05/03/85 // W $75.3 / / 11 / 04 / 85$ // must loose weight!)

Irrelevant propositions are:

(portrait: all the visible characteristics of the patient not referring to sex or age // name; Jenkins Rosemary // address; 2 avenue 9th // profession; house-wife // insurance; Z.Z.L. // Caesarean Section // 1982 // Cholecystectomy // fam. history; M: gallstones // 10/07/84 // cough // bronchitis // Vibramyc. // 05/03/85 // knee complaints // artrosis? // R/ Ibuprofen 400 3dd // 11/04/85 // still complaining about right knee)

When confronted with his own diagnosis subject 07 recalled:

"Yes she has had a cholecystectomy in 1979, in 1978, ...." "It was that woman isn't it"? "It was quite a heavy woman, with eh.. with such nice curly black hair, and eh.. if I remember well she was about 50 year old, 1932 or something like that". "Yes there was something about overweight, ..... on her medical card overweight was continuously reported ......" "I cannot recall more".

The subjects score was as follows:

she: Literal recall; cholecystectomy: Literal recall; in1979, in 1978: Incorrect recall; quite a heavy woman, with nice curly black hair: Partial recall;about 50 year old, 1932 or something like that: Partial recall; overweight: Summary (content); continuous reported: Summary (frequency-aspect);

For this case, subject 07 obtained a total of 6 tallies, 4 with relevant items and 2 with irrelevant items.

Figure 5.1: Case number 4, a case of diabetes mellitus, consisted of three slides. 
For instance, one subject recalled.."on her medical card overweight was continuously reported ......". In this case 2 tallies were given, one for 'overweight' (= content-aspect) and one for 'continuously' (= frequency-aspect). The recall score consisted of the total number of tallies given. An example of this procedure is illustrated in figure 5.1. Interrater agreement with this procedure was $91 \%$.

Group differences in diagnostic accuracy, response-times and recall of contextual information under the various case presentation orders of the experiment, were analyzed by means of one and two way analyses of variance.

\section{Results}

In order to explore the way experts and novices activate scripts, we analyzed the effect of case-presentation-order on diagnostic accuracy, mean response-time, as well as the amount of information recalled. The recall was scored in terms of its relevance, category (literal, partial, inferred or summary), and the different enabling conditions (age, sex, operations, medication etc.).

\section{Diagnostic accuracy}

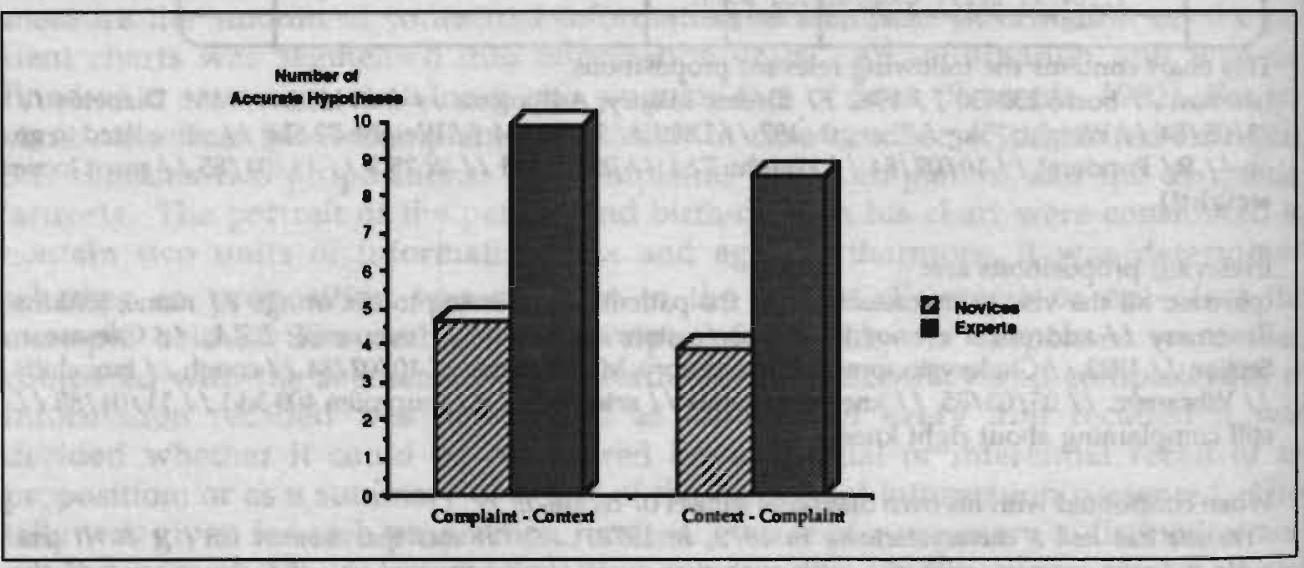

Figure 5.2: Number of accurate hypotheses mentioned by Experts and Novices in two information presentation conditions.

Table 5.1: Diagnostic Accuracy of Experts and Novices

\begin{tabular}{llllllllll}
\hline & \multicolumn{2}{c}{ Complaint-Context } & \multicolumn{3}{c}{ Context-Complaint } & \multicolumn{3}{c}{ Total } \\
& Mean & SD & n & Mean & SD & n & Mean & n \\
\hline Novices & 4.6 & 1.8 & 8 & 3.9 & 2.8 & 8 & 4.3 & 16 \\
Experts & 9.9 & 2.6 & 8 & 8.5 & 2.7 & 8 & 9.2 & 16 \\
\hline Totals & 7.25 & 3.5 & 16 & 6.19 & 3.6 & 16 & & 6.72 & 32
\end{tabular}


Presentation order of contextual information and complaint had no effect on the accuracy of hypotheses generated, $F(1,28)=1.46, p=.24$. In comparison with the novice-group however, the expert-group generated far more accurate diagnoses in both conditions: $F(1,28)=31.45, p<.001$. No interaction was found, $F(1,28)=.126, p=.73$.

With reference to the statements made in the introductory part, these results suggest that factual knowledge within scripts is more important that the way these scripts are activated.

\section{Response times}

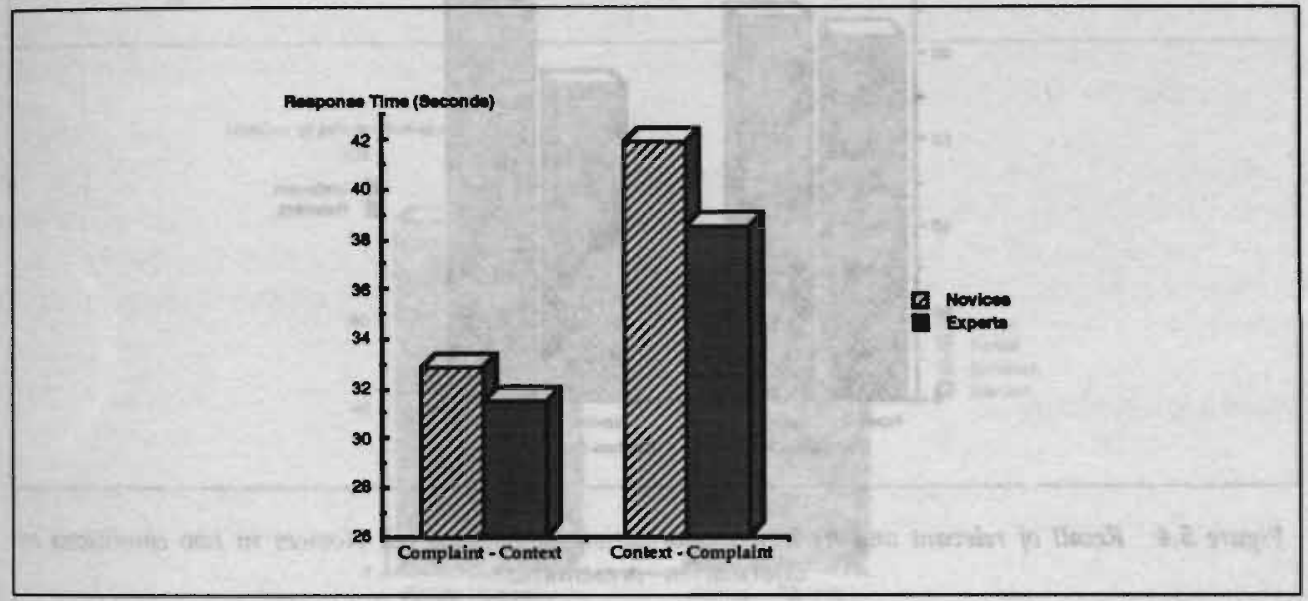

Figure 5.3: Mean response time (seconds) of Experts and Novices in two conditions of information presentation.

Table 5.2: Mean Response time (seconds) of Experts and Novices

\begin{tabular}{lccccccccc}
\hline & \multicolumn{3}{c}{ Complaint-Context } & \multicolumn{3}{c}{ Context-Complainlt } & \multicolumn{3}{c}{ Total } \\
& Mean & SD & n & Mean & SD & n & Mean & n \\
\hline Novices & 32.9 & 3.5 & 8 & 41.9 & 3.4 & 8 & 37.4 & 16 \\
Experts & 31.5 & 3.3 & 8 & 38.5 & 2.1 & 8 & 35.0 & 16 \\
\hline Totals & 32.2 & 3.4 & 16 & 40.2 & 3.2 & 16 & 36.2 & 32
\end{tabular}

The order in which cases were presented had a strong effect on response-times: $(F(1$, $28)=52.56, p<.001$. If the complaints were presented before the portraits and medical cards, subjects responded much faster than those subjects who were faced with contextual information first. Furthermore an effect of expertise was found $(F(1,28)=$ $4.72, p<.05)$. Experts' response times are shorter than novices'. Although an interaction was not found $(F(1,28)=.88, p=.36)$, expert-novice differences are more 
noticeable in cases where context is presented before the complaint: $F(1,15)=6.02, p$ $<.05$, versus $F(1,15)=.637, p=.44$ in the complaint context order.

These results jointly suggest that illness scripts are more easily activated by complaint information. However, in case contextual information is given first, expertnovice differences suggests that experts' script activation shows some triggering by contextual information as well.

\section{Recall of Relevant Information.}

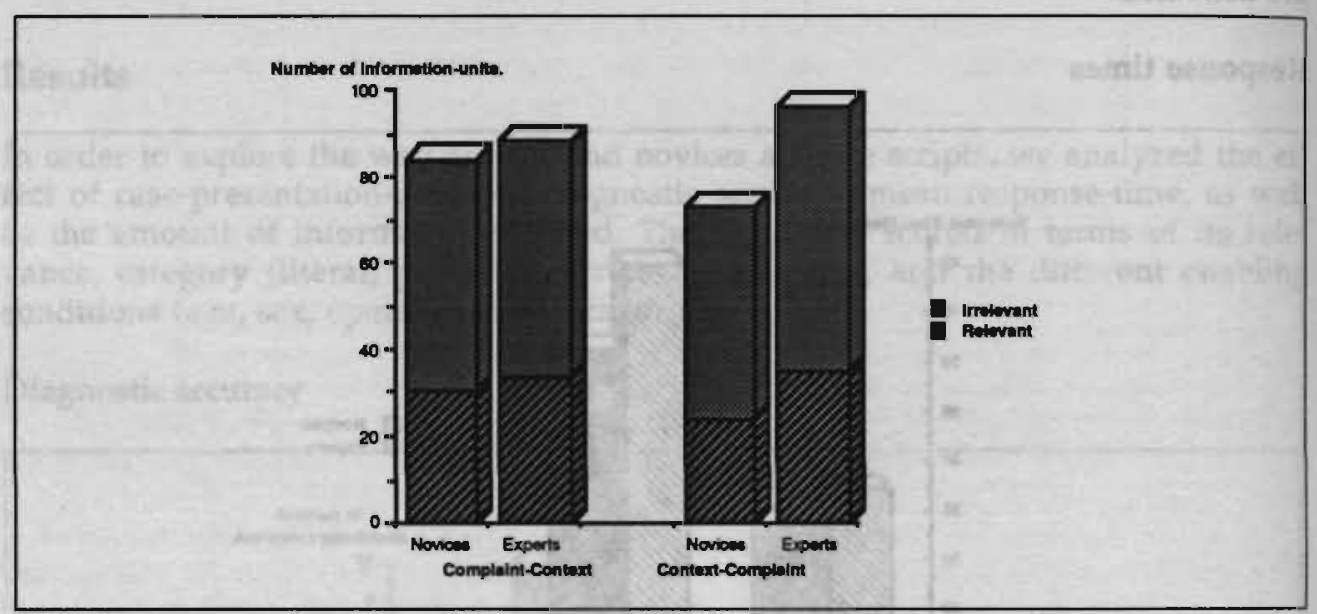

Figure 5.4: Recall of relevant and irrelevant information by Experts and Novices in two conditions of information presentation.

Table 5.3: Recall of Contextual Information by Novices and Experts

\begin{tabular}{rrrrrrrrrr}
\hline & \multicolumn{3}{c}{ Complaint-Context } & \multicolumn{3}{c}{ Context-Complaint } & \multicolumn{3}{c}{ Total } \\
& Mean & \multicolumn{1}{c}{ SD } & n & Mean & SD & n & Mean & n \\
\hline Novices Recall & 84.1 & 11.7 & 8 & & 73.0 & 18.1 & 8 & 78.5 & 16 \\
Relevant & 54.1 & 8.3 & & 49.0 & 13.2 & & 51.5 & \\
Irrelevant & 30.1 & 9.0 & & 24.0 & 6.4 & & 27.0 & \\
Experts Recall & 88.5 & 17.5 & 8 & 96.5 & 20.1 & 8 & & 92.5 & 16 \\
Relevant & 54.6 & 8.5 & & 61.6 & 12.4 & & 58.2 & \\
Irrelevant & 33.8 & 10.2 & & 34.8 & 8.6 & & 34.3 & \\
\hline
\end{tabular}

Totals

$\begin{array}{lll}86.3 & 14.5 & 16\end{array}$

$\begin{array}{lll}84.7 & 22.1 & 16\end{array}$

$85.5 \quad 32$

Presentation order did not affect recall of contextual information (total, relevant or irrelevant: $F(1,28)=07, p=.80, F(1,28)=.07, p=.80$ and $F(1,28)=.70, p=.41)$. However, experts recalled more information than novices $(F(1,28)=5.28, p<.05)$. More specific they recalled more irrelevant information $(F(1,28)=5.68, p<.05)$. 
Also, there is a tendency of experts to recall more relevant information than novices $F(1,28)=3.0, p=.09$, especially in the context-complaint order $F(1,15)=3.91, p=.07$ (in contrast with $F(1,15)=.02, p=.89$ in the complaint-context order). An. interaction-effect in this respect however was not found $(F(1,28)=2.49, p=.13)$, neither was there an interaction effect in the recall of irrelevant propositions $(F(1$, $28)=1.33, p=.26)$ or the total number of propositions $(F(1,28)=2.49, p=.13)$.

Recall measures do not clearly fit with expectations that may emanate from results on response times. These namely suggested script activation to be easier by the complaint. In comparison to novices, experts seem to process relevant contextual information presented in advance of the complaint more extensively.

Recall Categories

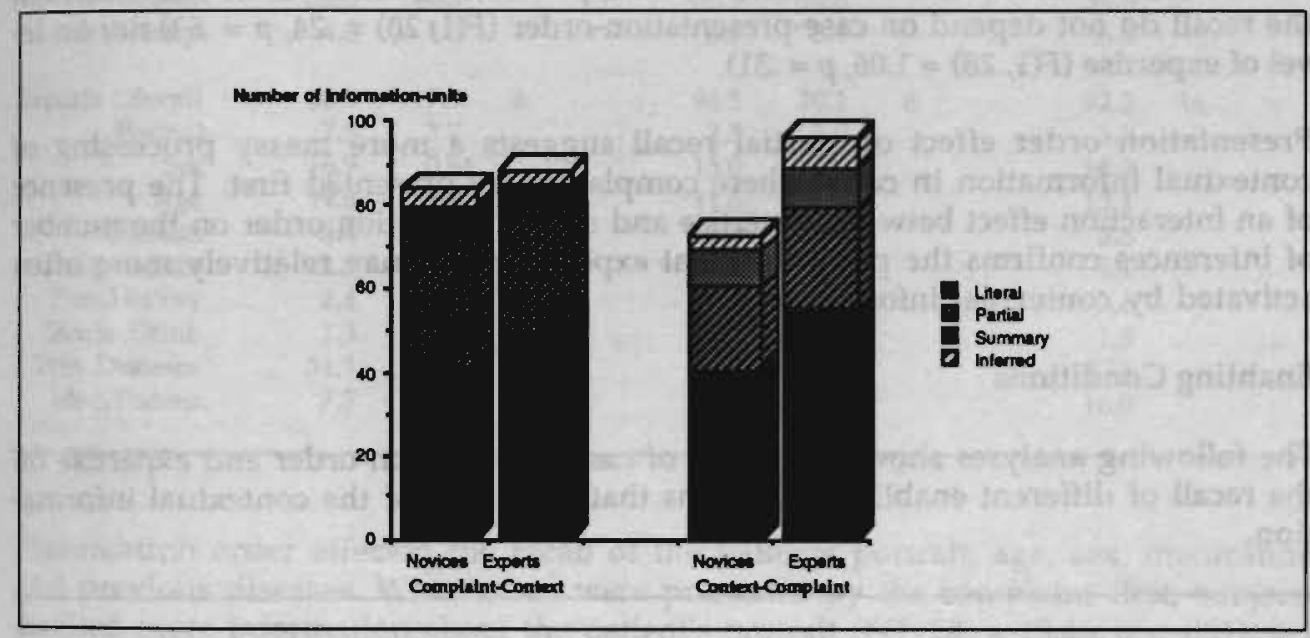

Figure 5.5: Categories in the recall of Experts and Novices of information presented in two conditions

Table 5.4: Recall Categories of Novices and Experts

\begin{tabular}{|c|c|c|c|c|c|c|c|c|}
\hline & Comp & nt-Con & & Conte & Compl & & Tot & \\
\hline Categonies & Mean & SD & $\mathrm{n}$ & Mean & SD & $\mathbf{n}$ & Mean & $\mathbf{n}$ \\
\hline Novices Recall & 84.1 & 11.7 & 8 & 73.0 & 18.1 & 8 & 78.5 & 16 \\
\hline Literal & 41.8 & 4.9 & & 40.3 & 9.7 & & 41.0 & \\
\hline Partial & 27.6 & 8.2 & & 20.3 & 7.5 & & 23.9 & \\
\hline Summary & 10.2 & 2.1 & & 8.9 & 2.4 & & 9.6 & \\
\hline Inferred & 4.5 & 2.4 & & 3.5 & 2.0 & & 4.0 & \\
\hline Experts Recall & 88.5 & 17.5 & 8 & 96.5 & 20.1 & 8 & 92.5 & 16 \\
\hline Literal & 49.6 & 11.1 & & 55.5 & 10.5 & & 52.7 & \\
\hline Partial & 28.0 & 6.4 & & 23.9 & 7.1 & & 25.9 & \\
\hline Surnmary & 7.1 & 4.0 & & 9.6 & 3.6 & & 8.3 & \\
\hline Inferred & 3.8 & 2.5 & & 7.5 & 4.6 & & 5.6 & \\
\hline
\end{tabular}


In order to detect differences in the nature of cognitive processing the number of literal, partial, inferred and summarized units recalled were analyzed irrespective of their relevance.

Both groups demonstrate more partial recall when complaints are presented before the portraits and medical cards $(F(1,28)=4.94, p<.05)$. Compared to novices, experts show more literal recall $(F(1,28)=12.16, p<.01)$. Moreover, the number of inferences made, show a differential effect of case-presentation order in the two groups ( $F(1$, $28)=4.91, p<.05)$. Experts infer more when contextual information is provided before the complaint $(F(1,15)=4.16, p=.06)$, contrary to novices. Novices infer less in the context-complaint condition as compared to novices who studied the case information in the reversed order $(F(1,15)=.82, p=.38)$. The number of summaries in the recall do not depend on case-presentation-order $(F(1,28)=.24, p=.63)$ nor on level of expertise $(F(1,28)=1.06, p=.31)$.

Presentation order effect on partial recall suggests a more messy processing of contextual information in cases where complaints are presented first. The presence of an interaction effect between expertise and case presentation order on the number of inferences confirms the prediction that experts scripts may relatively more often activated by contextual information.

\section{Enabling Conditions}

The following analyses show the results of case presentation order and expertise on the recall of different enabling conditions that were part of the contextual information.

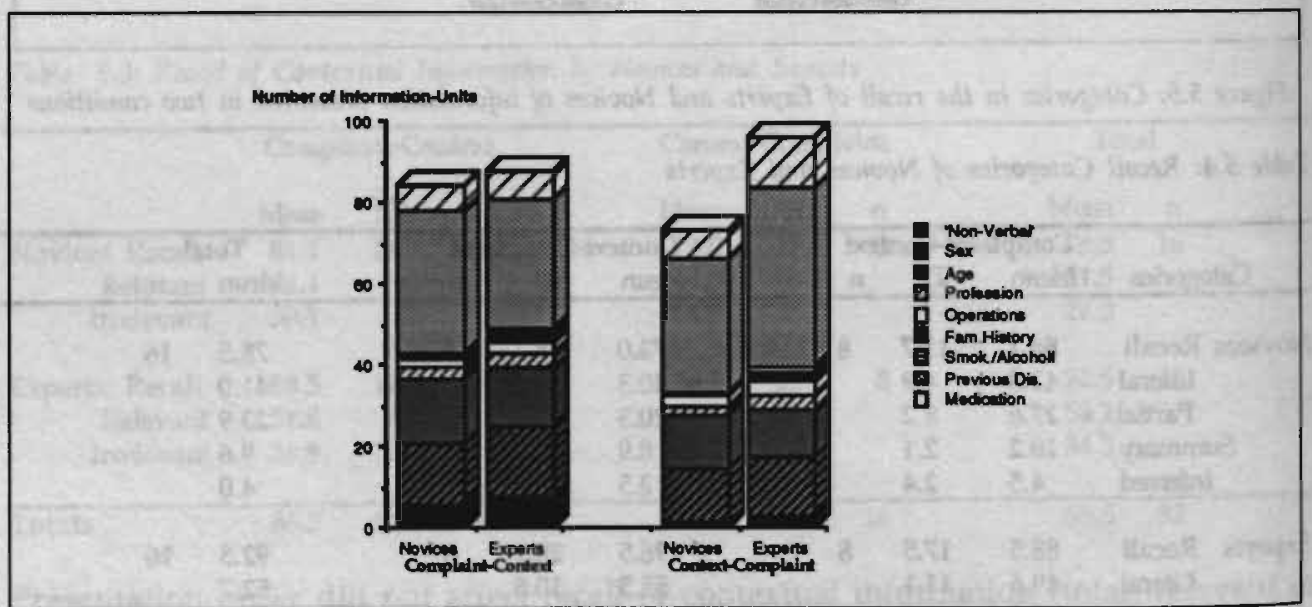

Figure 5.6: Enabling Conditions categories in the recall of Experts and Novices of information presented in two conditions 
Table 5.5: Recall of Enabling Conditions of Experts and Novices

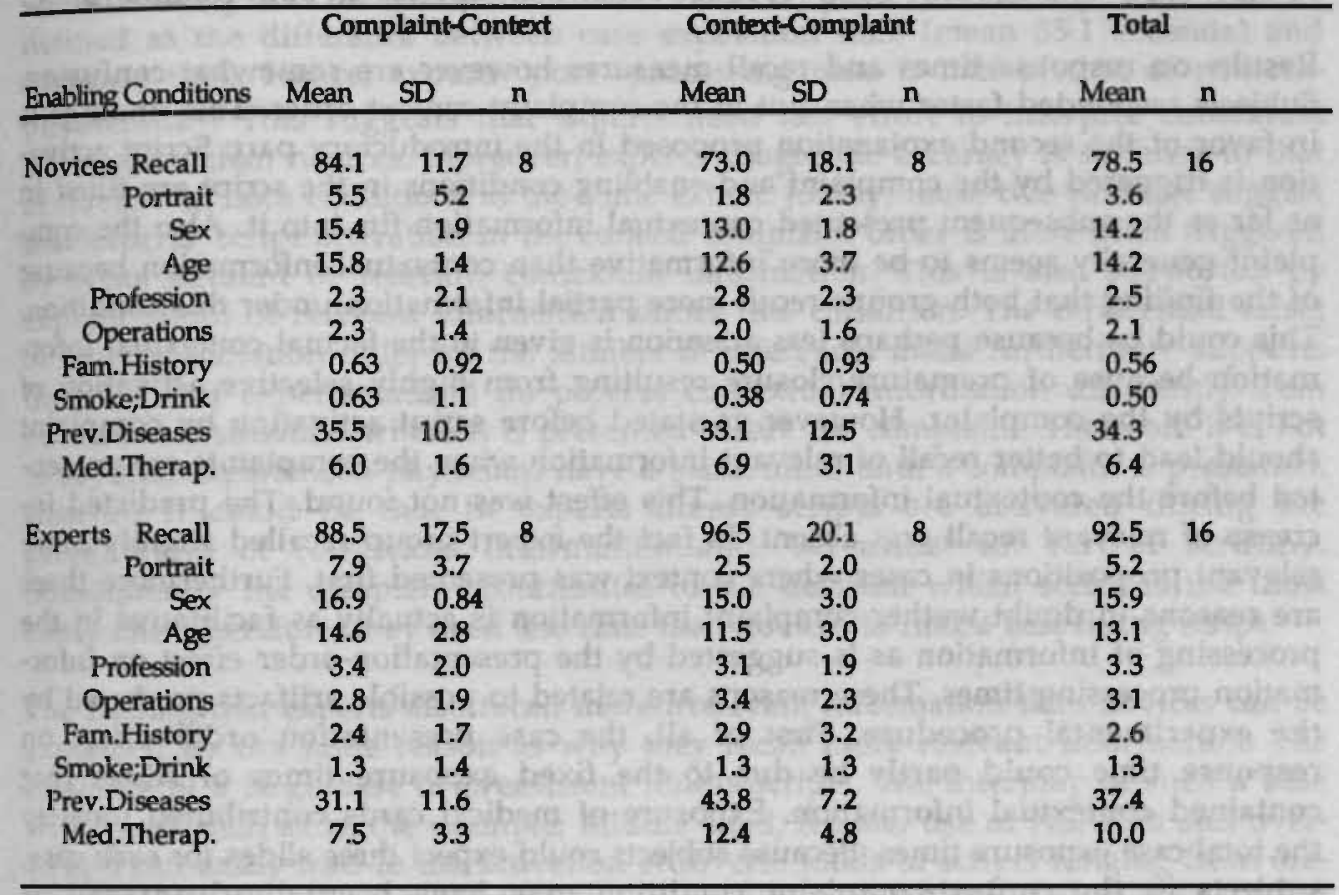

Presentation order affected the recall of the patients portrait, age, sex, medication and previous diseases. When cases were presented by the complaint first, subjects recalled more information about the patient's portrait $(F(1,28)=13.46, p<.001)$, sex $(F(1,28)=8.82, p<.01)$, and age $(F(1,28)=9.71, p<.01)$. Recall on information about medication was better when cases started with the presentation of contextual information $(F(1,28)=5.88, p<.05)$. Compared to novice physicians experts recall more about the patient's $\operatorname{sex}(F(1,28)=5.98, p<.05)$, family history $(F(1,28)=9.29, p<.01)$, and medication $(F(1,28)=8.67, p<.01)$. As far as information on previous diseases is concerned two way ANOVA shows an interaction of case presentation order and level of expertise $(F(1,28)=4.05, p<.05)$. That is to say, when contextual information is given first, novice physicians recall less $(F(1,15)=.17, p=.68)$, whereas experts recall more than their peers $(F(1,15)=6.98, p<.05)$.

\section{Discussion}

Subjects general way of script activation was explored. No differences were found in diagnostic accuracy of subjects under the two different conditions. Relevant illness scripts are activated independent of variance in required effort originating from the two different case presentation orders. This suggests that diagnostic performance 
primarily depends on subjects knowledge as such and not so much on the way scripts that represent this knowledge are most easily activated. Such is confirmed by the fact experts' diagnostic accuracy is far better than novices' in both conditions.

Results on response times and recall measures however are somewhat confusing. Subjects responded faster when put in the complaint-context order. This findings is in favor of the second explanation proposed in the introductory part: Script activation is triggered by the complaint and enabling conditions in the script are filled in as far as the subsequent presented contextual information fits into it. Also the cornplaint generally seems to be more informative than contextual information because of the finding that both groups recall more partial information under this condition. This could be because perhaps less attention is given to the factual contextual information because of premature closure resulting from highly selective activation of scripts by the complaint. However as stated before script activation by complaint should lead to better recall of relevant information when the complaints are presented before the contextual information. This effect was not found. The predicted increase of relevant recall was absent. In fact the expert group recalled slightly more relevant propositions in cases where context was presented first. Furthermore there are reasons to doubt wether complaint information is actually as facilitative in the processing of information as is suggested by the presentation-order effect on information processing times. These reasons are related to possible artifacts produced by the experimental procedure. First of all, the case presentation order effect on response time could partly be due to the fixed exposure times of slides that contained contextual information. Exposure of medical cards contributed most to the total case exposure times. Because subjects could expect three slides for each case, subjects in the context-complaint condition may have been disadvantaged as compared to subjects in the other condition since, in order to read all the information they had to await the complaint-slide which was presented at the end. Secondly the instruction did not explicitly permit them to respond before the end of each case presentation. In addition subjects were allowed to state only one (most likely) hypothesis. One cannot preclude the possibility that some of the subjects were able to generate a relevant hypothesis before the presentation of the complaint, but did not generate one because they thought they had to wait for the complaint ${ }^{1}$ or wanted to take advantage of all the case information in order to be more sure about an already activated script. Therefore, the effects of presentation order on processing time of information can not fuily be understood. In conclusion, the most reasonable explanation is that in general neither complaint nor context driven script activation is predominant. Script activation by complaints may be easier and more selective but scripts are probably to some extent activated by contextual information as well.

The effects of expertise found in the results of the present study are in favor of our research question. It was predicted that experts' illness script activation is more often than novices' triggered by contextual information. First, this prediction seems to be confirmed by the results on the response times measures: Experts processing times are shorter than that of novices, especially in cases where context is presented before

${ }^{1}$ On the other hand, subjects in the complaint-context order quite often stated their diagnosis while the third slide (medical card) was still projected. 
the complaint. Assuming that in a situation where portraits and medical cards are given first, case exposition time is mainly used for reading contextuall information. while waiting for the complaint-slide, subjects 'pure' processing- time can be defined as the difference between case exposition time (mean 35.1 seconds) and response time. Hence, experts 'pure' processing time is half of that of novicesphysicians ${ }^{1}$ ! This suggests that experts need less effort to interpret contextual information than novices. Moreover, experts' diagnostic accuracy is superior to that: of novices in both conditions to the same extent. Jointly, these two findings suggest: that experts' script activation in the context complaint order is more often triggered by some amount of relevant contextual information. This is also supported by experts' recall of relevant information under this condition. The differential effect: of case presentation order on the number of inferences made furthermore supports the idea that experts indeed do process contextual information differently from novices in a situation where it is presented before the complaint. Therefore it is not to say that experienced physicians have a blank mind until a complaint is presented. Instead, it could be that in experts illness scripts are activated during the presentation of contextual information and "set aside" for further scrutiny. Subsequently the complaint contributes to the decision which script is the most: likely one. Therefore, they need less tinne than novices to find a best fitting script.

The finding that experts also recall more irrelevant information than novices can be explained by the same reason as why they recall more relevant information: The existence of a large base of preexistent illness scripts. The interplay of such a base: with items such as in the example: Middle aged, female, use of NSAID's and overweight can easily lead to the activation of diverse kinds of scripts ranging from dialbetes mellitus (middle aged + female + overweight) or gastritis (use of NSAID's) to postmenopausal involution depression (middle aged + female) or artrosis of the knee (middle aged + overweight). This processing of contextual information in the presence of multiple scripts will automatically lead to the recall of information which in retrospect is irrelevant, especially in a situation where complaint informaltion is still unknown and interpretative processing already occurs. As experts are expected to posses the indicated large base of preexistent illness-scripts and (compared to novice-physicians) show evidence of immediate and extensive interpretations of medical cards and portraits even before the complaint is known (as evidenced by response times and inferences), they can be expected to recall more irrelevant propositions.

Therefore it can be concluded that experts' skill in interpreting medical cards and portraits before the complaint is given, obviously is not selective enough to produce mainly relevant hypotheses. Complaint information probably remains necessary in order to differentiate between relevant and irrelevant scripts. Especially in novices, the complaint seems to be the most important script-activating information, as was demonstrated in an earlier experiment (Hobus, 1988). Therefore total and literal recall of contextual information is poor as compared to experts. Experts on the other hand posses preexistent illness scripts rich in enabling conditions and tuned to realworld information. Accordingly, information on the medical cards and portraits fit

${ }^{1} 38.5^{\prime}$ minus $35.1^{\prime}=3.4^{\prime}$ for experts versus $41.9^{\prime}$ minus $35.1^{\prime}=6.8^{\prime}$ for novices. 
into these preexistent knowledge structures unmodified which results in more literal recall.

An additional question was which enabling conditions in particular activate relevant scripts in experts. It is hard to predict effects of expertise and presentation orders within the recall of the various enabling conditions (e.g. sex, age, operations, previous diseases, medication etc.). Because selected cases were not meant to be representative of all the patient problems met with in general practice, recall of different enabling conditions could probably depend on specific case characteristics as well. First of all, the analyses suggest that the role of portraits differ with its presentation (after or before the complaint). When they already know the complaint, experts and novices recall more about sex and age of the patient, as well as other (medically irrelevant) portrait features. As was discussed earlier, scripts activated by the complaint, are probably less in number but more accurate than those activated by the context. The scripts activated by the complaint seem to be generally completed by enabling conditions like sex and age. Therefore, these items appear to be very informative in the presence of a complaint. Or to put it another way: Age and sex as such, are too general triggers to activate relevant scripts. For instance: A middle aged woman potentially can have such a large number of diseases that this information in itself is non-informative. On the other hand when you know the patient has pain in the lower abdomen, the same kind of information (sex and age) becomes of utmost importance to the selection of appropriate scripts. In such a case, certain diseases of the internal female genital tract become more likely, whereas youngster-diseases like appendicitis, or male diseases like prostatitis can be discarded. In summary, sex and age, have a different value dependent on the nature of script activation. Information about medication however, is recalled better when it is presented before the complaint. This again, may be an effect of the differential informative value of context in different situations. In contrast to sex and age, medication provides more specific information with constant diagnostic value. Information like: Ibuprofen $400 \mathrm{mg} 3$ times daily, can lead a physician directly to specific scripts related to the indications for such a prescription like: Artrosis, and reumatoid arthritis or scripts related to the possible side-effects of such drugs: Gastric ulcer and myeloproliferative disorders. In other words: the range of possible scripts related to certain medication is small. Therefore, in a situation where the complaint is not yet available, the patient's medication potentially has important diagnostic value. Under the complaint context condition however, scripts activated by the complaint already predominate and information about medication will probably only be scanned superficial to check wether it fits into these scripts. Seldomly medication in itself will activate new unexpected scripts or significantly narrow down the range of possible scripts in the way sex and age do. As a result, attention towards medication may be different in the two conditions and this may explain the recall differences found.

The expert novice differences in the recall of sex, family history, and medication suggest that during the refinement of illness scripts they are mostly enriched with these enabling conditions; at least they become more sensitive for such information. 
An interesting interaction effect was found in the amount of information recalled from previous disease-episodes. Experts remember more of this information than novice physicians in cases where it is presented before the complaint. These items take up almost $45 \%$ of the total information typed on the medical chard. Furthermore from a medical point of view such information is very complex to interpret. Its value is somewhere in between that of information like sex and age and information such as medication. So, on the one hand, it can be almost non-informative, but also very selective (as soon as a set of illness scripts are activated). On the other hand, like information on medication use, it can be very concise and of stable diagnostic value. The fact that expertise and case-presentation-order show an interaction in the recall of such information, once more suggests that expert's ability to provide structure to these data in advance of the complaint, must be an effect of an elaborate knowledge-base containing numerous refined illness scripts.

\section{Conclusion}

Taken together the results presented in this study show that script activation is triggered by complaint as well as context information. No final conclusion could be reached with respect to which type of information in general is the most dominating in diagnostic reasoning. Context may help narrowing down the range of possible scripts, but in order to decide on the most likely one(s) in a given case, complaints are more informative than knowledge about previous disease history or other enabling conditions. Script activation triggered by context can only be accomplished in the existence of a large knowledge-base that contains numerous refined illness scripts, presumptively several for each diagnosis.

The present study definitely demonstrates that experts' script activation in comparison with novices is more often triggered by contextual information. Experts utilize contextual information in a more relevant, thorough, and rapid manner, especially when it is presented before the complaint. The results also indicate the existence of interpretations based solely on information about the patients previous disease-episodes. Further research needs to be done on which enabling conditions are generally the most important during this early but most important stage in medical diagnosis.

\section{References}

Anderson, J. R. \& Reder, L. M. (1979). An Elaborative Processing Explanation of Depth of Processing. In: L. S. Cermak, \& Craik (Eds.), Levels of Processing in Human Memory. (pp. 385-403). Hillsdale, New Yersey: Lawrence Erlbaum Associates.

Barrows, H.S., Norman, G.R., Neufeld, V.R. \& Feightner, J.W. (1982). The clinical reasoning of randomly selected physicians in general medical practice. Clinical \& Investigative Medicine, 5 , 49-55.

Berne, E. (1977). Intuition and Ego States. San Francisco: Harper \& Row Publishers. 
Boshuizen, H.P.A. (1989). De ontwikkeling van medische Expertise; Een cognitief-psychologische benadering. [On the development of Medical Expertise; A cognitive Psychological Approach.] (Doctoral Dissertation University of Limburg). Haarlem: Thesis Publishers.

Brandsford, J.D., Sherwood, R., Veye, N. \& Rieser, J. (1986). Teaching thinking and problem solving. American Psychologist, 41, 1078-1089.

Elstein, A.S., Shulman, L.S. \& Sprafka, S.A. (1978). Medical problem-solving: an analysis of clinical reasoning. Cambridge, MA: Harvard University Press.

Feltovich, P.J. \& Barrows, H.S. (1984). Issues of generality in medical problem solving. In: H.G. Schmidt \& M.L. De Volder. M.L. (Eds.), Tutorials in problem-based learning; A new direction in teaching the health professions, (pp. 128-142). Assen: Van Gorcum.

Hobus, P.P.M., Schmidt, H.G., Boshuizen, H.P.A. \& Patel V.L. (1987). Contextual factors in the activation of first diagnostic hypotheses: Expert-novice differences. Medical Education, 21, 471476.

Hobus, P.P.M., Hofstra, M., Boshuizen, H.P.A. \& Schmidt, H.G. (1988). De context van de klacht als diagnosticum. [The context of the complaint as a diagnostic tool.] Huisarts en Wetenschap, 31, 261-263.

Hobus, P.P.M, Boshuizen, H.P.A, Schmidt, H.G. (1989, july) Mental representation of prototypical patients: expert-novice differences. Paper presented at the first European Congress of Psychology, Àmsterdam.

Schmidt, H.G, (1982). Activatie van voorkennis, intrinsieke motivatie en de verwerking van tekst.[Activating prior knowledge, intrinsic motivation and text processing] (Doctoral Dissertation University of Limburg), Apeldoorn. Van Walraven.

Schmidt, H.G., Boshuizen, H.P.A. \& Hobus, P.P.M. (1988). Transitory stages in the development of medical expertise: The "intermediate effect" in clinical case representation studies. Proceedings of the Cognitive Science Saciety Meeting. (pp. 139 - 145), Hillsdale, New York: Lawrence Erlbaum.

Schmidt, H. G., Norman, G. R. \& Boshuizen, H. P. A. (1990). A cognitive perspective on medical expertise: Theory and implications. Academic Medicine, 65, 611-621.

Snoek, J.W. (1989). Het denken van de neuroloog. [Reasoning in Neurology.] (Doctoral Dissertation University of Groningen). Groningen: Computekst

Style, A. (1979). Intuition and Problem Solving. Journal of the Royal College of General Practitioners, 29, 71-74. 


\section{HOOFDSTUK 6}

\section{EXPERT-NOVICE DIFFERENCES IN THE MENTAL REPRESENTATIONS OF PATIENT PROTOTYPES}

Eerder gepubliceerd als:

Hobus, P.P.M, Boshuizen, H.P.A, \& Schmidt, H.G. (1989, july) Mental representation of prototypical patients: expert-novice differences. Paper presented at the first European Congress of Psychology, Amsterdam. 


\section{Summary}

When a doctor is consulted by a patient, very soon after the complaint is uttered, hypotheses about what is wrong with this patient will cross his/her mind.

From previous studies on the generation of early hypotheses (Hobus, Schmidt, Boshuizen, \& Patel, 1987; Hobus, Hofstra, Boshuizen, \& Schmidt, 1988), it is known that the accuracy of these first hypotheses of experienced physicians is enhanced by the availability of contextual information, consisting of items like age, sex, profession, risk behavior, previous diseases and medication of the patient. However, availability of this information did not affect the diagnostic performance of a knowledgeable, but inexperienced group.

Although these studies demonstrate the experts' ability to identify relevant cues in the contextual information of the complaint, they do not reveal the knowledge structures accounting for this. Research in categorization and medical expertise suggest that experts' and novices' knowledge differ with respect to the representation of prototypical patients with a specific disease. These patient prototypes would differ in the elaborateness of the contextual information, providing a key to the experts' early hypotheses.

To test this notion, eight novices (inexperienced $M D^{\prime} s$ ) and eight experts (experienced family physicians) were encouraged to describe prototypical patients in response to 18 pairs of complaints and associated diagnoses. Results show large proportions of contextual information in expert prototype representations of and large proportions of disease signs and symptoms in novice representations. Group differences on both measures were significant.

The results suggest that differences in knowledge structures between experts and novices may explain the experts' ability to select contextual information that is relevant to a patient's diagnosis, whereas novices, primarily relying on complaint interpretation while diagnosing a patient, do not benefit from this kind of information. 
Medical expertise is of course associated with better performance. Experienced doctors are expected to come up with better diagnoses and better treatment plans than their inexperienced colleagues. This better performance was shown in research carried out by Elstein, Shulman, and Sprafka (1978) and Barrows, Norman, Neufeld, and Feightner (1982). In these studies, experienced physicians not only produced better diagnoses, but even the first hypotheses that come to their mind, fit better with the patients' actual disease. This latter finding is congruent with general problem-solving theory. This theory predicts that the quality of an initial internal problem representation determines the efficiency and accuracy of further thinking (Glaser, 1984). Thus, already at the very moment a patient utters a complaint, the quality of the doctors' initial representation of the problem largely predicts his final success. In this initial representation a diagnostic hypothesis is formed as a result of knowledge activated by some of the patient information.

In two experiments, Hobus and others (Hobus, Schmidt, Boshuizen, \& Patel 1987; Hobus, Hofstra, Boshuizen, \& Schmidt, 1988) demonstrated that experts' superior performance in producing accurate diagnostic hypotheses largely depends on the use of so-called contextual information. Contextual information is information about the patient, available to the physician like sex and and age, or profession, risk behavior, previous diseases or operations and medication. In one of these experiments (Hobus et al. 1988) 16 experienced family physicians and 16 graduate medical students were randomly assigned to two conditions. In one condition complaints were presented together with the patients' portraits and medical cards. For instance the complaint :"Last day I have a stabbing pain in the middle of my back, it's so worse that sometimes I am fainting" was accompanied by the portrait of an old man and his medical card. Some of the information on his card was of diagnostic value like: blood pressure values (which were too high), measured at very irregular intervals (indicating bad patient compliance), information on his heavy smoking and the prevalence of heart and vessel disease in his family. This relevant information was mixed up with other irrelevant information like that of a pneumonia in 1978 and some previous operations. For each of the 18 cases presented subjects had to generate a most likely hypothesis (the correct diagnosis in the example-case is a Dissecting Aortic Aneurysm which is a longitudinal splitting of the arterial wall; often a result of severe atherosclerotic degeneration and high blood pressure). As could be expected, the experienced family physicians generated more than twice as much accurate diagnoses as compared to the inexperienced medical graduates. In the other condition; portraits and medical cards were omitted so that only complaints were presented to the subjects. Now the experts' accuracy was significantly inferior to that of their peers in the first condition. The performance of novices however, hardly decreased when the portraits and medical cards were left out. This suggests that the accuracy of their early mental representation of the patient's possible illness is not enhanced by the availability of contextual information. Although these studies show the experts' ability to identify relevant cues in the contextual in- 
formation of the complaint, they don't reveal the type of disease knowledge that is used for a correct interpretation of this kind of information.

In order to investigate the knowledge structures that account for the phenomenon found, we first have to decide upon a model of problem representation in medicine that incorporates the role of "contextual information". Such a model is provided in Feltovich and Barrows' theory on illness scripts (Feltovich \& Barrows, 1984). in their view, diagnosticians construct a representation of the patient's illness that consist of three component parts that are interrelated. Those illness features associated with the acquisition of illness are labeled as Enabling Conditions. Instances of enabling conditions are predisposing factors like alcohol and nicotine abuse, or boundary conditions like sex and age. The second category of features: Faults, contains the major malfunctions that lead to the third category of features: Consequences. An example of this is the inadequate oxygen supply of myocardial tissue (which can be considered the fault), that leads to anginal symptoms and eventually cardiac or systemic complications like bradycardia or cyanosis (which are the consequences). Enabling conditions in such an example are for instance, old age, male sex and heavy cigaret smoking which are associated with the development of atherosclerosis responsible for the inadequate oxygen supply. In view of this illness: script theory, the results of our earlier studies suggest that experts' superiority lies in the more adequate use of contextual cues as enabling conditions for the fault at hand.

In the present study, we want to explore those knowledge structures that appear to be crucial in interpreting contextual information as enabling conditions for a fault. Feltovich and Barrows themselves assume basic-science knowledge (pathophysiology, etc.) "to play an integral role in the construction of illness scripts, by constraining and guiding the manner in which script components can be structured together". However, other options are possible as well. Instead of laborious application of rules derived from memory structures that contain declarative knowledge from the basic medical sciences, physicians could well exploit a rapid patternmatching type of thinking. Schmidt, Boshuizen, and Hobus (1988) and Bosh.uizen, Schmidt, and Coughlin (1988). have shown that, in contrast to intermediates, experts do not extensively reason through causal (pathophysiological) networks when they diagnose a case. Instead of encoding patient information in terms of pathophysiological explanations, they assume that experts categorize patient information into knowledge structures containing pre-existent list-like illness scripts. In this view the confrontation with a medical problem leads to the activation of preexistent illness-scripts from memory. These pre-existent scripts could either be a set of descriptions of prototypical (though idiosyncratic) patients or of instances of concrete patients dealt with in the past (see also: Schmidt, Norman, \&t Boshuizen, 1990). This so-called patient knowledge, e.g. descriptions of prototypical patients or concrete instances of patients with a certain disease, is less abstract than the knowledge of pathofysiological mechanisms and related disease symptoms. Therefore, a real life abstraction, for instance a prototypical patient with a myocardial infarction is more likely to change and develop through daily experience, than a conceptual abstraction like long term oxygen deficit of myocardial 
tissue and its related symptoms (the pathophysiological disturbance in a case of myocardial infarction).

For this reason we expected expert-novice differences in prototype-knowledge to be found in the representation of more concrete categories like the knowledge of patients associated with specific diseases. In this study therefore, subjects of different levels of expertise were presented with complaint-diagnosis pairs and requested to describe as extensively as possible a prototypical patient that fits with both diagnosis and complaint. Because of the discussed difference between experts and novices in their ability to identify enabling conditions in the context of a complaint, differences in prototypical patient representations are expected to show in a larger proportion of enabling conditions in the experts' descriptions.

In order to investigate this hypothesis eight experienced and eight inexperienced physicians were asked to describe their representation of prototypical patients in response to the presentation of 18 complaints-diagnosis pairs. Resulting prototypes were analyzed, using Feltovich \& Barrows' model on illness script as the representational tool.

\section{Method}

\section{Subjects}

Subjects were 16 physicians and graduate medical students. The expert group consisted of eight family physicians who on the average had $15.1( \pm 10.6)$ years of experience in primary health care. Average age was $44.4( \pm 9.2)$ years. The novices were 2 final year medical students who were about to graduate and 6 physicians who graduated less than 6 month prior to the experiment. Their average age was $26.8( \pm 1.7)$ years.

\section{Material}

The stimulus material consisted of 18 complaints-diagnosis pairs derived from 18 case histories, selected from a large set of case-descriptions about real patients availabie at the University of Limburg Medical School. Case histories were selected as to have contextual information play an important role in the correct interpretation of the complaint. Experts' diagnostic performance on these cases had already been shown to be very susceptible to manipulations of the presence of enabling conditions (Hobus et al. 1988). The complaint-diagnosis pairs covered all organ systems.

\section{Procedure}

The 18 combinations of complaints and diagnoses were read to the subjects sequentionally. For each pair the subject had to describe, as extensively as possible, his or her idiosyncratic prototypical patient. All responses were audiotaped. Presentation-order of the combinations was varied systematically over subjects.

Analysis

A verbatim transcription was derived from the audiotaped responses. These transcripts were segmented into information units. An information unit was de- 
fined as a statement containing one singular fact or idea. (for instance:"More often a man than a woman", or: "Well it's a retroperitoneal proces") Before any further analysis, units that did not contain patient- or disease-related information were removed. Resulting units were assigned to categories of Feltovich and Barrows' model by an experienced family physician. For each information-unit it was determined whether it was part of the model and if so, whether it could be considered an enabling condition, fault or consequence of the generated prototypical illness script (see the two examples in table 6.1).

\section{Table 6.1: Examples Analysed Protocols}

Subject 32 responding to item 1 (Stabbing back pain and fainting = Dissecting Aortic Aneurysm) Information-units between brackets

" 1: [Men as well as women.] 2: [I think the disease presents itself almost equally among both sexes,] but maybe.but let's say it's 3: [more often a man than a woman]. Eh.. 4: [Age varies but certainly is above 70 year] eh... those are 5: [people that are known with a hypertension] and which 6: [are treated for that]. It's possible 7: [you already had found an aneurysma if you had done a physical examination in the past].. haha...It's 8: [acute], it's a 9: [severe pain] and it often presents itself 10: [like a renal colic] eh...it can just as well be a 11: [back pain] or an 12: [abdominal pain] or 13: [general malaise],.. those are 14: [such complaints that can be categorized anywhere]."

ENABLING CONDITIONS: UNIT 1, 3, 4, 5, 6 and 7

FAULTS: none

CONSEQUENCES: UNIT $8,9,10,11,12$ and 13

NON-MODEL UNITS: UNIT 2 and 14

Subject 22 responding to item 1 (Stabbing back pain and fainting = Dissecting Aortic Aneurysm) Information-units between brackets

"Yes...yes someone with, ehm..what I see before me yet is 1: [a younger person, let's say about.... 40 to 55 year]... that eh.. 2: [well it's a retroperitoneal proces], they have 3: [some back pain], 4: [most of the times it radiates to the groin], 5: [the pubic area]. Some one with 6: [sensations of coldness], 7: [restlessness]...eh 8: [irritated],.... 9: [feeling of not being well with a certain tension, which is a clear component]. Such a person I have in mind."

ENABLING CONDITIONS: UNIT 1

FAULTS: UNIT 2

CONSEQUENCES: UNIT $3,4,5,6,7,8$ and 9

NON-MODEL UNITS: none

As already mentioned in the introductory part we were interested in expert-novice differences with regard to the internal structure of prototype-knowledge, not whether parts of this knowledge are correct. Therefore no attempts were made to account for accuracy with respect to presented diagnosis (for instance; one can doubt whether subject 22 is right in saying patients with a dissecting aortic aneurysm are generally younger than 55 years of age). In order to investigate differences between the two subject groups in prototype representation, the total number of model and non-model units as well as proportional amounts of enabling conditions, faults and 
consequences in illness scripts, were analyzed by means of one-way-analyses-of-variance.

\section{Results}

For each subject group, figure 6.1 shows the number of information units, assigned to the three categories of Feltovich and Barrows' model (Feltovich \& Barrows, 1984). Units that did not fit this model are indicated by the non-model label. These units contain information with respect to patient's management and prognosis as well as diagnostic pitfalls related to the patient's disease.

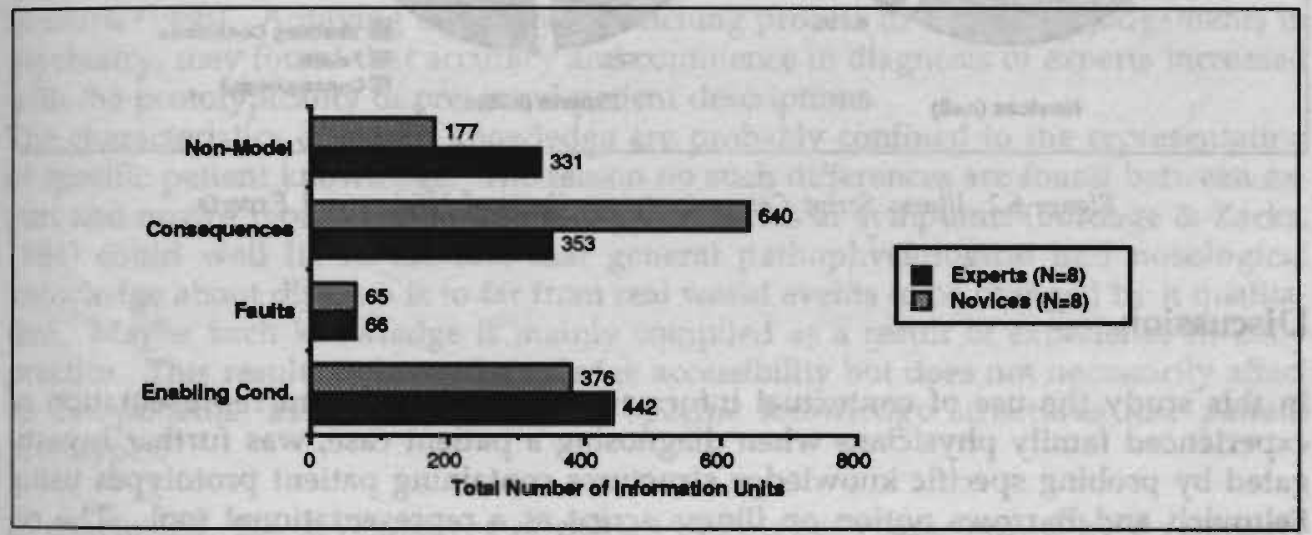

Figure 6.1: Prototype Information in (Non-) Illness Script Categories

In an unstructured task like ours, no differences are expected with regard to the effort the subject groups take in generating patient prototypes. This is confirmed by the results showing an almost equal number of information units produced by the two groups ( 1258 by the novices, 1192 by the experts). The number of model and non-model units did not differ between groups $(F(1,14)=1.90, p>.10$ respectively $F(1,14)=3.49, p>.05)$. Model units of novices predominantly contained information concerning the signs and symptoms (consequences) of the prototypical patient, whereas the experts' mental representations mainly described enabling conditions.

Because proportions of the various script categories in the generated prototypes are expected to play an important role in cue identification of patient information, further analyses are directed on measures corrected for the total number of illness script units.

The proportion of enabling conditions, faults and consequences that were generated by the novices and the experts are iliustrated in figure 6.2. Significant differences; were found in the proportions of enabling conditions and consequences. The prototype-patients of novices have a larger proportion of consequences than those of experts $(F(1,14)=5.99, p<.05)$, whereas those of the experts have a larger proportion of 
enabling conditions $(F(1,14)=6.26, p<.05)$. There was no difference in the proportion of faults $(F(1,14)=.37, p>.10)$.

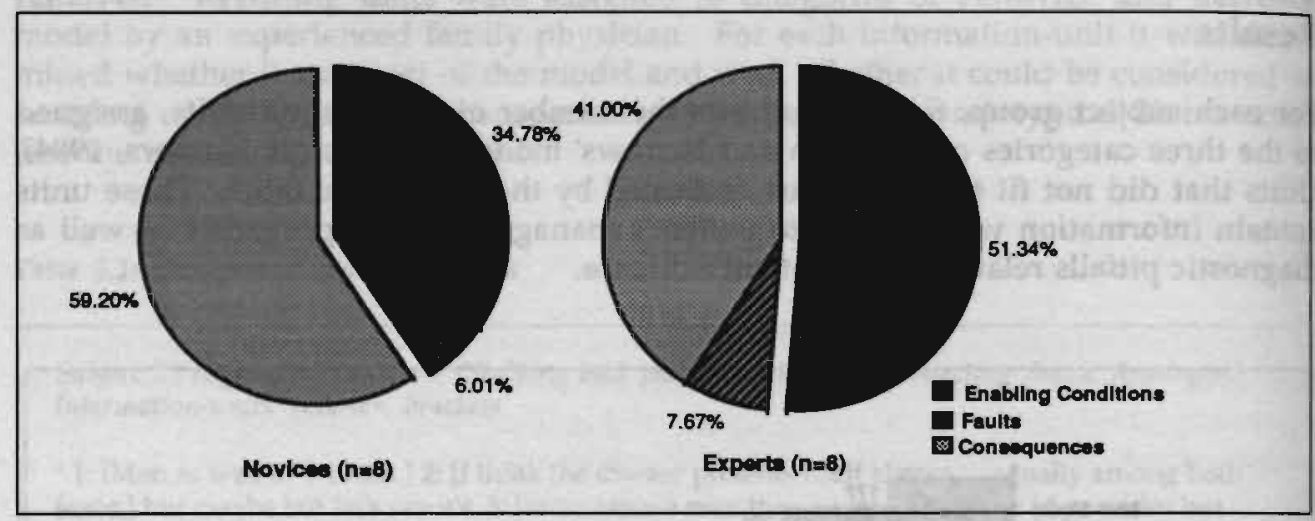

Figure 6.2: Illness Script Categories (proportions) of Novices and Experts.

\section{Discussion}

In this study the use of contextual information in early problem representation of experienced family physicians when diagnosing a patient case, was further investigated by probing specific knowledge structures containing patient prototypes using Feltovich and Barrows notion on illness script as a representational tool. The results show clear differences between experienced and inexperienced physicians in script constituents representing enabling conditions and consequences of diseases. These results suggest that, in the development of expertise, knowledge associated with the acquisition of illness like the patient's sex, age, previous disease history, or medication becomes more prominent in the representation of prototypical patients. Novice representation however, is characterized predominantly by signs and symptoms found in a patient with a certain disease.

The tendency of the expert group to generate more non-model knowledge, can be seen as an effect of goal-orientation, since in generating a prototypical patient, the expert makes direct links to relevant knowledge concerning how to handle such patients and their probable prognosis. In addition he immediately links the patient's disorder to other, to be differentiated, diseases.

The results of illness script analysis of prototypical patients carried out on the present data are in accordance with the expectations that arose from our earlier studies on hypothesis generation. In these studies, the accuracy of early diagnostic hypotheses generated by expert physicians was shown to improve by the presentation of enabling conditions in the context of 18 complaints. In the present study, when asked to describe typical patients with the diseases actually connected to these 18 complaints, experts reveal a relatively large number of enabling conditions in the 
descriptions, in their view belonging to the stimuli presented. The proportion of enabling conditions in the illness scripts generated is significantly larger than the proportion of these elements in the novice group. The novice group however, reveals a larger proportion of consequences in their descriptions of prototypical patients, indicating a predominantly "symptom-oriented" knowledge structure. Such structure explains why novice diagnostic performance mainly depends on complaint interpretation as such and is unaffected by cues that can be found in the context of the complaint. The characteristics of knowledge representation found in the group of experienced family physicians can account for the accuracy of information processing they exhibit by identifying enabling conditions in the contextual information at the moment a complaint is presented to them.

The results presented in this study support those of Cantor, Smith, French, and Mezzich (1980). Applying a prototype-matching process to diagnostic judgements in psychiatry, they found that accuracy and confidence in diagnosis of experts increased with the prototypicality of presented patient descriptions.

The characteristics of expert knowledge are probably confined to the representation of specific patient knowledge. The reason no such differences are found between expert and novice representation of prototype diseases or symptoms (Bordage \& Zacks, 1984) could well lie in the fact that general pathophysiological and nosological knowledge about diseases is to far from real world events to be changed by it qualitative. Maybe such knowledge is mainly compiled as a result of experience in daily practice. This results in better knowledge accessibility but does not necessarily affect its components, as seems to occur in specific knowledge structures like patient prototypes.

In conclusion, the development of patient prototypes characterized by a relatively large proportion of enabling conditions in the subjects protocols may explain the experts' superior diagnostic performance already at the moment patients express their complaints. Furthermore, these findings give some support to the perspective of Schmidt et al. (1989) who consider experts' performance primarily as a function of shallow processing patient information within specific list-like illness scripts that fit real world constraints.

\section{References}

Barrows, H.S., Norman, G.R., Neufeld, V.R. \& Feightner, J.W. (1982). The clinical reasoning of randomly selected physicians in general medical practice. Clinical \& Investigative Medicine, 5 , 49-55.

Bordage, G. \& Zacks, R. (1984). The structure of medical knowledge in the memories of medical students and general practitioners; Categories and prototypes. Medical Education, 18, 406-416.

Boshuizen, H.P.A., Schmidt, H.G. \& Coughlin, L.D. (1988). On the application of medical basic science knowledge in clinical reasoning; implications for structural knowledge differences between experts and novices. Proceedings of the 10th Annual Conference of the Cognitive Science Society, Montreal, Canada. 
Cantor, N., Smith, E.E., French, R. \& Mezzich, J. (1980). Psychiatric diagnosis as prototype categorization. Journal of Abnormal Psychology, 89, 181-193.

Elstein, A.S., Shulman, L.S. \& Sprafka, S.A. (1978). Medical problem-solving: an analysis of clinical reasoning. Cambridge, MA: Harvard University Press.

Feltovich, P.J. \& Barrows, H.S. (1984). Issues of generality in medical problem solving. In: H.C. Schmidt, \& M.L. De Volder (Eds.),Tutorials in problem-based learning; $A$ new direction in teaching the health professions, (pp. 128-142). Assen: Van Gorcum.

Glaser R. (1984). Education and Thinking. The Role of Knowledge. American Psychologist, 39, 93-104.

Hobus, P.P.M., Hofstra, M., Boshuizen., H.P.A. \& Schmidt, H.G. (1988). De context van de klacht als diagnosticum. [The context of the complaint as a diagnostic tool.] Huisarts en Wetenschap, 31, 261-263.

Hobus, P.P.M., Schmidt, H.G., Boshuizen, H.P.A. \& Patel V.L. (1987). Contextual factors in the activation of first diagnostic hypotheses: Expert-novice differences. Medical Education, 21, 471476.

Schmidt, H.G., Boshuizen, H.P.A. \& Hobus, P.P.M. (1988). Transitory stages in the development of medical expertise: The "intermediate effect" in clinical case representation studies. Proceedings of the 10th Annual Conference of the Cognitive Science Society, Montreal, Canada.

Schmidt, H.G., Norman, G.R. \& Boshuizen H.P.A. (1990). Cognitive research on clinical reasoning: Theory and implications. Academic Medicine, 65, 611-621. 


\section{HOOFDSTUK 7}

\section{SAMENVATTING EN IMPLICATIES}




\section{Inleiding}

De centrale these die we in dit proefschrift verdedigen is dat ervaren artsen betere diagnostische prestaties leveren dan artsen met minder ervaring, omdat zij meer en intensiever gebruik maken van contextuele informatie over patiënten die hen werden voorgelegd. Met contextuele informatie bedoelen we informatie die een arts over zijn patiënten heeft. Die informatie is: (1) hetzij gebaseerd op directe ervaringen met één specifieke patiënt, (2) hetzij opgebouwd op basis van de ervaringen die die arts in de loop der jaren met het vórrkomen en verloop van ziektebeelden bij meerdere patiënten gehad heeft. Die kennis helpt hem het aantal mogelijke diagnostische alternatieven gegeven de klacht of de symptomen die de patiënt presenteert, in te perken tot een klein aantal waarschijnlijke. Een voorbeeld van de eerste categorie, specifieke kennis van een specifieke patiënt, is het volgende: als een huisarts weet dat in een tot zijn praktijk behorend gezin recent ernstige problemen zijn ontstaan met de oudste zoon en de moeder verschijnt op het spreekuur met ernstige hoofdpijnklachten, dan zal de arts niet in de eerste plaats denken aan een sinusitis of iets dergelijks maar zal hij een relatie leggen met de ernstige relatieproblemen thuis waardoor zijn gedachten eerder uitgaan naar spanningshoofdpijn. Een voorbeeld van de tweede categorie is de wetenschap van de huisarts dat een 20 jarige of 70-jarige vrouw met a-typische buikklachten beduidend verschilt in de kans waarmee bij hen sprake kan zijn van een anatomisch substraat. In dit laatste voorbeeld is het niet zozeer precieze kennis van de omstandigheden waarin een individuele patiënt zich bevindt en de daaruit resulterende gezondheidsklachten, maar het betreft kennis over de condities waaronder bepaalde ziekten voor kunnen komen. Die kennis is gecumuleerd over de jaren waarin de arts vele patiënten gezien heeft die een bepaalde ziekte hadden en in wiens ziektegeschiedenis signalen voorkwamen die de arts samen met het ziektebeeld zelf heeft opgeslagen. Ervaren artsen weten bijvoorbeeld dat bij ouderen met een vrij plotseling optredende dyspnoe d'repos zonder voorgeschiedenis van CARA ze aan een cardiale oorzaak moeten denken, en specifiek in het geval van een bestaande diabetes mellitus aan een 'stil' infarct.

Contextuele kennis is in wezen probabilistisch van aard. Het gaat om informatie over ziekte die noch een noodzakelijke noch een voldoende voorwaarde vormt voor het optreden van een bepaalde ziekte bij een patiënt. Zoals een ervaren arts eens zei: "Als een volwassen patiënt mondspruw heeft, dan zie je regelmatig dat dit het gevolg is van een ontregelde diabetes of dat in de periode daaraan voorafgaand antibiotica, corticosteroiden of cytostatica gebruikt werden." De kennis die ervaren artsen helpt hun zoekruimte in te engen (Newell \& Simon, 1972), is dus veelal associatief van aard. Het is niet noodzakelijk dat er een onderliggend causaal pathofysiologisch verband bestaat tussen de informatie die al over een patiënt beschikbaar is en de huidige klacht of het huidige ziektebeeld (al kan dat natuurlijk wel, of zou $z^{\prime}{ }^{\prime} n$ causale relatie op $z^{\prime} n$ minst vermoed kunnen worden $\left.{ }^{1}\right)$. Om die reden spreken

\footnotetext{
1Een voorbeeld van dat eerste is roken als causale factor bij het ontwikkelen van een bronchuscarcinoom; aanvankelijk kon dit alleen vermoed worden. Inmiddels is vast komen te
} 
wij in dit proefschrift steeds over contextuele informatie. Het gaat immers niet om informatie die direct deel uitmaakt van het betreffende ziektebeeld, maar die ervaren artsen in de context daarvan vaak opmerken. Het begrip 'Enabling Conditions' dat Feltovich en Barrows (1984) introduceerden is in feite een al te sterke omschrijving omdat dit begrip op $z^{\prime} n$ minst suggereert dat het om omgevingscondities gaat die een noodzakelijke voorwaarde voor het optreden van een bepaalde ziekte vormen.

Verder is contextuele informatie deels idiosyncratisch van aard. Omdat ze mede gebaseerd is op de persoonlijke ervaringen van een bepaalde arts, kan ze afwijken van kennis die andere artsen hebben opgedaan met bepaalde ziekten in hun context. Omdat in onze visie het verwerven van contextuele kennis vooral een functie is van de hoeveelheid ervaring die artsen met de diagnose van een bepaalde ziekte hebben opgedaan, kunnen we vermoeden dat er verschillen bestaan tussen artsen onderling als het gaat om de rijkdom van hun contextuele kennis van die ziekten. Uit het onderzoek dat we in hoofdstuk 6 van dit proefschrift presenteren, blijkt overigens wel dat, als artsen een rijk kennis bestand hebben met betrekking tot de context, die kennis dan ook onderling vergelijkbaar is. Dat wil zeggen dat artsen met een vergelijkbare hoeveelheid ervaring met een bepaalde ziekte aan dezelfde signalen aandacht besteden. Blijkbaar vormt praktijkervaring de kennisstructuren van artsen toch op een vergelijkbare wijze ${ }^{1}$.

Naast het associatieve, idiosyncratische en probabilistische karakter van contextuele kennis is een additioneel kenmerk dat die kennis slechts beperkt uit boeken verworven lijkt te kunnen worden; het is typische ervaringskennis of kennis die slechts onder invloed van die ervaring geactiveerd wordt (zie voetnoot 1). Handboeken op het terrein van de geneeskunde besteden wel degelijk aandacht aan contextuele factoren bij het optreden van ziekte. Een voorbeeld is de uitgebreide aandacht voor de risicofactoren van atherosclerose niet alleen van de leerboeken doch zelfs van de populaire pers. Studenten lijken daar echter niet in de zelfde mate van te kunnen profiteren als van de pathofysiologische kennis van ziekte en de symptomatologie. Wellicht komt dit omdat vanwege het associatieve karakter van context lastig een causaal model van de situatie geconstrueerd kan worden (Gentner \& Stevens, 1983) dat studenten helpt die informatie te onthouden en

staan dat roken inderdaad een factor in het causale proces die uiteindelijk tot bepaalde vormen van longkanker leidt. Een voorbeeld van contextuele informatie waarbij maar heel misschien een causaal verband tussen context en ziekte vermoed kan worden, is dat herpes zoster bij een gestresste volwassene vaker ontstaat nadat hij in aanraking is geweest met een kind met waterpokken.

I Op grond van de in dit proefschrift verzamelde data is nog een andere verklaring mogelijk voor het feit dat de ziektescripts van ervaren artsen meer op elkaar lijken dan we zouden mogen verwachten op grond van de hypothese dat contextuele informatie ervaringskennis pur sang is. Niet uitgesloten kan worden dat studenten kennis van contextuele aspecten van ziekte well degelijk gedurende het theoretische deel van hun voorbereiding op het artsenberoep leren, maait dat die kennis aanvankelijk niet goed geïntegreerd is in het zich ontwikkelende ziekte script. De toegankelijkheid van die informatie zou vervolgens toenemen onder invloed van de ervaring. Met andere woorden: kennis van contextuele factoren is aanwezig vanaf het begin van de praktijkbeoefening -artsen onderschrijven dit- maar wordt pas onder invloed van de ervaring bruikbaar. 
vooral: te gebruiken. Dat kunnen we tenminste afleiden uit experiment II waarvan we de resultaten in hoofdstuk 3 van dit proefschrift bespreken: in tegenstelling tot de diagnostische prestatie van ervaren artsen wordt die van de onervaren artsen nauwelijks beïnvloed door aan- of afwezigheid van context. Dat duidt erop dat de laatste groep van die informatie niet of nauwelijks gebruik maakt, ondanks het feit dat veel van deze kennis in hun opleiding wel aan de orde is geweest. Blijkbaar moet de rol van context 'aan den lijve' ervaren worden wil die functioneren in de professionele praktijk.

We geven in de volgende paragrafen een samenvatting van onze voornaamste bevindingen en van de experimenten waarop die bevindingen betrekking hebben. Daarna beschrijven we de theoretische noties die aanleiding hebben gegeven tot de ondernomen studies. Aangegeven wordt op welke wijze onze bevindingen een bijdrage leveren aan de verdere ontwikkeling van die theorie. Nieuwe vragen die het onderzoek heeft opgeworpen komen daarbij aan de orde. Tenslotte bespreken we enkele implicaties van het onderzoek voor onderwijs in de geneeskunde en de geneeskundige praktijk.

\section{De invloed van contextuele kennis op diagnostische prestaties}

De theoretische basis voor het onderzoek vormde het idee dat artsen bij de diagnose van ziekten de beschikking hebben over zogenaamde ziekte scripts (Feltovich \& Barrows, 1984), cognitieve structuren waarin hun kennis over bepaalde ziekten georganiseerd is. Volgens Feltovich en Barrows bestaan die scripts uit drie elementen: 'enabling conditions': datgene wat wij hier eerder contextuele informatie noemden; een 'fault': de disfunctie van het organisme en van de pathofysiologische mechanismen die tot de disfunctie aanleiding geven; en 'consequences': de gevolgen van de disfunctie zoals die tot uitdrukking komen in klachten en symptomen. Kennis van de context en kennis van de klachten en symptomen samen zouden in diagnostische situaties leiden tot de identificatie van de disfunctie. We hebben hiervoor betoogd dat het, in onze visie, de kennis is van de context waarin ziekte kan ontstaan, die van groot belang is bij de diagnostiek, in ieder geval bij huisartsen. Daarnaast hebben we aangenomen dat bij de ontwikkeling van ziekte scripts praktische ervaring met ziekte in al zijn verschijningsvormen een belangrijke determinant is. Naarmate een arts meer ervaring heeft met een bepaalde ziekte, is zijn of haar ziekte script voor die ziekte meer gekristalliseerd en rijker aan contextuele informatie. Om deze thesen te onderzoeken, hebben we een aantal experirnenten uitgevoerd die we hieronder nog eens zullen samenvatten.

In Hoofdstuk 2 beschrijven we een experiment waarin 18 ervaren huisartsen en 17 bijna of net afgestudeerde basisartsen werden geconfronteerd met 32 sets van drie dia's. De eerste dia bestond steeds uit een foto van een patiënt waaruit leeftijd en geslacht zouden kunnen worden afgeleid. De tweede dia beeldde de zogenaamde 'groene kaart' af waarop informatie over de patiënt in kwestie was weergegeven zoals woonplaats, aard van het werk, leefgewoonten, medicatie, vroegere ziekten en operaties, etc. De derde dia gaf steeds een korte beschrijving van een klacht of symp- 
toom weer, bijvoorbeeld: "Ik ben enkele keren niet goed geworden, mijn hart ging dan zo tekeer. En verder heb ik de laatste dagen een paar keer moeten overgeven". De eerste twee dia's toonden dus contextuele informatie over de patiënt. De dia's werden vertoond gedurende een gefixeerde hoeveelheid tijd. De taak van de proefpersonen was om, gegeven deze op het oog zeer summiere informatie over een patiënt, een eerste diagnostische hypothese te formuleren. De juistheid of onjuistheid van die eerste diagnostische hypothese kon vastgesteld worden doordat de 32 patiëntbeschrijvingen gebaseerd waren op 'echte' patiënten bij wie de aard van hun ziekte met zekerheid was vastgesteld. De resultaten lieten zien dat ervaren huisartsen, dat wil zeggen artsen met gemiddeld ongeveer 10 jaar ervaring, een aanzienlijk betere prestatie leverden dan de groep van bijna of net afgestudeerde basisartsen. De ervaren huisartsen stelden op basis van de informatie in bijna $40 \%$ van de gevallen een correcte diagnose, terwijl dat bij de onervaren artsen in $27 \%$ van de gevallen was. De proefpersonen werden achteraf nog gevraagd welke informatie zij zich van de getoonde patiënten herinnerden. Het bleek dat ervaren artsen zich gemiddeld genomen ongeveer $25 \%$ meer informatie van de dia's herinnerden, hetgeen erop duidt dat zij de informatie intensiever cognitief verwerkt hadden. Het verschil was volledig terug te voeren op het onthouden van potentieel relevante informatie voor de betreffende ziekte; irrelevante informatie werd niet beter onthouden. Uit deze bevindingen hebben wij geconcludeerd dat de betere diagnostische prestatie van ervaren artsen is terug te voeren op het feit dat die artsen een intensiever gebruik maken van contextuele informatie bij het interpreteren van de klacht of het symptoom. Dat blijkt niet alleen uit het feit dat relevante contextuele informatie beter onthouden werd; dat blijkt ook uit het feit dat de hoeveelheid onthouden relevante informatie 0,63 correleerde met de juistheid of onjuistheid van de diagnose (terwijl onthouden irrelevante informatie niet met prestatie gecorreleerd bleek). Deze resultaten suggeren dat expertise dus vooral een functie lijkt te zijn van een rijk en functionerend bestand aan contextuele kennis gerelateerd aan kennis van symptomen en klachten die met een bepaalde ziekte gepaard gaan.

In de discussie over dit eerste experiment wezen we op het feit dat er nog alternatieve verklaringen mogelijk zijn voor het gevonden resultaat. Men kan, gegeven de opzet van het experiment, niet uitsluiten dat de ervaren artsen een betere prestatie leverden niet zozeer omdat ze intensiever gebruik maakten van de contextuele informatie, maar bijvoorbeeld omdat ze beter uitgewerkte lijsten met mogelijke diagnosen gegeven een bepaalde klacht hebben. Men kan niet uitsluiten dat artsen een persoonlijke epidemiologie ontwikkelen die hen vertelt welke ziekte het meest waarschijnlijk is, gegeven de aard van een klacht of symptoom. Om een causaal verband tussen het gebruik van contextuele informatie en diagnostische prestatie te vinden, is feitelijke experimentele manipulatie met die context-informatie vereist.

Een dergelijk experiment rapporteren we in hoofdstuk 3 . In dat tweede experiment presenteerden we aan 16 ervaren en 16 onervaren artsen 18 casus onder twee condities. 8 ervaren en 8 onervaren artsen kregen de 18 casus mèt context aangeboden; dat wil zeggen dat zij voor elke casus het portret, de groene kaart en de klacht geprojecteerd kregen. De overige 8 onervaren en 8 ervaren artsen kregen alleen de klacht te zien. De eerste conditie bestond dus uit de klacht plus de contextuele informatie; bij 
de tweede was de context afwezig. Als ervaren artsen intensiever gebruik maken van de context, dan mag verwacht worden dat het weglaten van de context meer invloed heeft op de prestaties van die groep dan op de prestaties van onervaren artsen. De resultaten ondersteunden deze hypothese. Wanneer de context in de vorm van het portret en de groene kaart aanwezig was, formuleerden de ervaren artsen in niet minder dan $54 \%$ van de gevallen een correcte diagnose. Was die context afwezig, dan is dat nog maar in gemiddeld $31 \%$ van de gevallen zo. De resultaten tonen daarenboven aan dat onervaren artsen veel minder profiteren van de aanwezigheid van contextinformatie: $26 \%$ versus $19 \%$ juiste diagnosen. De diagnostische prestaties van experts verminderen dus met $23 \%$ wanneer de context afwezig is, terwijl die van onervarenen slechts met $7 \%$ afneemt. Een statistisch significant interactie-effect tussen expertise-niveau en manipulatie van de context ondersteunt deze conclusie. Experts hebben veel meer voordeel van contextuele informatie dan beginnende artsen. Met andere woorden: ervaren medici gebruiken al datgene wat ze over een patiënt weten of kunnen weten op een intensievere wijze dan beginners. In die laatste groep is sprake van onderutilisatie van feitelijk beschikbare informatie. Daar dit experiment ook het in het eerste experiment gevonden verschil in prestaties tussen ervarenen en onervarenen repliceerde, concludeerden wij dat het toenemend gebruik van contextuele informatie een ervaringsfenomeen is. Artsen leren contextuele informatie gebruiken onder invloed van hun ervaringen met patiënten.

Deze stelling illustreren we op treffende wijze met een studie die we in hoofdstuk 4 beschrijven. In die studie werd de diagnostische prestatie op de taak die in de hiervoor besproken experimenten gebruikt werd, gerelateerd aan het aantal jaren dat een arts in de praktijk werkzaam was. Er bleek een positief verband tussen beide variabelen. De Pearson productmoment correlatiecoëfficiënt was gelijk aan 0,69. Dat betekent dat niet minder dan $47 \%$ van de variantie in prestatie tussen de deelnemende artsen verklaard kon worden uit de hoeveelheid ervaring die zij hadden, uitgedrukt in jaren in de praktijk. Interessant is dat het hypothetiseren van een lineaire relatie tussen beide variabelen geen lagere correlatie opleverde dan een tweede-orde verband dat op grond van intuitie en op grond van verhalen die onder artsen de ronde doen, eerder verwacht had mogen worden. Dat betekent dat diagnostische expertise betreffende het genereren van diagnostische hypothesen ook na 30 jaar in de praktijk nog lineair toeneemt (de oudste arts had 31 jaar werkervaring).

Experiment II bracht ons op het spoor van de relatieve invloed van de context versus de invloed van de klacht op de diagnose. De resultaten van dat experiment lieten immers zien dat ook op basis van de klacht alleen ervaren artsen nog betere prestaties leveren. Het was zelfs zo dat de experts in het experiment enkel op basis van de klacht hoger scoorden dan de beginners op basis van klacht plus context (al was dit laatste verschil niet statistisch significant). Dat leidt tot de vraag wat het relatieve belang is van beide soorten informatie bij de activatie van diagnosen. Is het $z 0$ dat de klacht de diagnose (of een aantal diagnoses) activeert, om vervolgens de plausibiliteit te evalueren op basis van de herinnering aan de (eerder verwerkte) contextinformatie? Of is het eerder omgekeerd? Suggereert context informatie wellicht een 
verzameling mogelijkheden die vervolgens wordt uitgedund als de klachtinformatie beschikbaar komt? Context zou in dat laatste geval een brede 'stage-setting' functie hebben in plaats van als een bron van informatie te functioneren waartegen concrete hypothesen getoetst kunnen worden. Er is anecdotische informatie die deze laatste optie ondersteunt. Artsen beweren dat zij vaak al weten wat een patiënt heeft, nog voordat deze de spreekkamer binnenkomt. Dit geldt met name voor patiënten met een hypochondrie of chronisch klaaggedrag.

De plausibiliteit van beide opvattingen testten we met een experiment waarvan we verslag doen in hoofdstuk 5 . Experts en beginnende artsen werden geconfronteerd met 18 patiëntenproblemen met de bekende drie dia's. Die dia's waren op twee manieren geordend. De helft van de proefpersonen kreeg eerst de klacht gepresenteerd en vervolgens de context dia's; de andere helft zag ze in de volgorde context-klacht. Naast diagnostische accuratesse werd bestuderingstijd gemeten en werd proefpersonen achteraf gevraagd wat zij zich van de verschillende casus herinnerden. De verwachting was dat als de klacht de diagnose zou activeren en de context vooral als testpool zou dienen, proefpersonen onder de conditie klacht-context betere prestaties zouden leveren in de zin van minder benodigde bestuderingstijd maar vooral betere herinnering van diagnose-relevante informatie. Als daarentegen diagnoses vooral door context-informatie gegenereerd worden, dan zou onder de context-klacht conditie informatie sneller verwerkt en zou onder deze conditie meer informatie onthouden moeten worden (relevante zowel als irrelevante ten aanzien van de uiteindelijke diagnose; de context kan immers aanleiding geven tot meerdere diagnoses). Indien de manier waarop de ziekte scriptkennis gebruikt wordt om diagnoses te genereren belangrijker is dan de beschikbaarheid van die ziekte scripts dan zullen eveneens de diagnostische prestaties beter zijn in die experimentele conditie die deze kennis het makkelijkst activeert.

We vonden echter geen verschillen in de diagnostische prestaties van beide expertgroepen, al produceerden zij weer significant meer goede diagnoses dan novieten. Dit betekent dus dat de inhoud van ziekte scriptkennis blijkbaar belangrijker is dan de manier waarop die kennis geactiveerd wordt. De hoeveelheid tijd die nodig was om een diagnose te produceren, was significant korter onder de klacht-context conditie. Dit suggereert dat diagnosen inderdaad vooral door de klacht gegenereerd worden. Technische tekortkomingen in de opzet van het experiment zouden hiervoor echter mogelijk verantwoordelijk kunnen zijn, mede omdat de resultaten met betrekking tot de hoeveelheid onthouden diagnose-relevante informatie de bovenstaande these niet ondersteunen. De recall resultaten geven eerder argumenten ten gunste van de activatie door contextuele informatie. Al met al konden we geen van de beide concurrerende verklaringen met dit experiment uitgesluiten. Duidelijk is wei dat zowel de klacht als contextuele informatie relevante ziekte scripts activeert. Niet zeker is welke van de 2 informatiebronnen daarin het meest expliciet is. De klacht lijkt hierin meer specifieke effecten te hebben dan contextuele informatie.

Ten opzichte van hun minder ervaren collega's blijken ervaren huisartsen echter reeds voordat de klacht gepresenteerd wordt intensief bezig met hypothesevorming zonder dat daardoor hun diagnostische superioriteit vermindert. Daarbij maken zij 
vooral gebruik van informatie betreffende vroegere ziekte-episoden van de patiënt en medicatiegebruik. Uit de verschillen in snelheid en diepte van verwerking van relevante informatie met de omstandigheid waarin de contextuele informatie vooraf gaat aan de klacht, leiden wij af dat ervaren huisartsen beschikken over een kennisbestand dat rijk is aan preëxistente ziekte scripts (waarschijnlijk meerdere per diagnose). Daardoor lijken ze in staat correcte ziekte scripts te activeren, enkel en alleen gebaseerd op specifieke informatie in de context zoals het medicijnengebruik of vroegere ziekte-episoden.

In hoofdstuk 6 tenslotte ondernemen we een poging de ziekte scripts die worden verondersteld ten grondslag te liggen aan de superieure diagnostische prestaties van ervaren artsen, op een meer directe wijze te onderzoeken. Daarbij maakten we gebruik van een narratieve methodologie (Schank \& Abelson, 1977). Artsen met verschillend niveau van expertise werden 18 sets bestaande uit een klacht en een diagnose voorgelegd met de vraag hun typische patiënt met deze klacht en deze diagnose te beschrijven. De resulterende protocollen werden geanalyseerd naar de aantallen verwijzingen naar enabling conditions, faults en consequences. De data laten zien dat de beschrijvingen van de experts meer contextuele (enabling conditions) informatie bevatten en minder verwijzingen naar klachten en symptomen. Deze bevindingen suggereren dat ervaren artsen inderdaad een rijker bestand aan kennis van de context hebben dan beginnende artsen, al is het verschil kleiner dan verwacht en kan het daarom niet helemaal de grote effecten van de context op diagnostische prestatie verklaren die eerder gevonden werd. Wellicht dat zowel ervaren als onervaren artsen deze kennis hebben, maar dat ze die kennis pas gebruiken onder invloed van de ervaring. Een tweede bevinding is dat het merendeel van de geproduceerde beschrijvingen goed waren te classificeren binnen de categorieën van het model van Feltovich en Barrows (1984). Nog interessanter wellicht is de bevinding dat artsen spontaan ook informatie betrekking hebbend op de behandeling van de verschillende aandoeningen produceerden, hoewel we daarom niet gevraagd hadden. Dit suggereert dat diagnose- en behandelingskennis deel uitmaken van eenzelfde script en daarom ook tegelijkertijd geactiveerd worden.

\section{Betekenis van deze bevindingen voor een theorie over de ontwikkeling van ziekte scripts}

De Maastrichtse onderzoekers Schmidt en Boshuizen hebben samen met enkele çollega's recent een ontwikkelingstheorie van medische expertise ontvouwd, die benadrukt dat medische studenten op weg naar expertise in hun vakgebied een aantal stadia doormaken waarin kennis een kwalitatief ander fkarakter krijgt 'Schmidt \& Boshuizen, 1993; Schmidt, Boshuizen, \& Hobus, 1988; Schmidt, Boshuizen \& Norman, 1992; Schmidt, Norman, \& Boshuizen, 1990; zie ook Boshuizen, 1989). In hun opvatting kenmerkt de eerste fase van die ontwikkeling zich door een tamelijk snelle uitbreiding van kennis die studenten van de geneeskunde opdoen. Tegelijkertijd worden door herhaling en toepassing van die kennis in de preklinische periode de relaties tussen de concepten in het semantische netwerk sterker en ontstaan nieuwe relaties in dat netwerk. Herhaling en toepassing leiden 
dus in het algemeen tot een betere toegankelijkheid van kennis als gevolg van hogere activatiewaarden die aan de betreffende verbindingen zijn gehecht. De kennis waar we hier op doelen is vooral de causaal-biomedische en (later) de pathofysiologische kennis die ziekte verklaart in termen van de onderliggende biologische determinanten. Klinische kennis, diagnostische labels, symptomatologie en handelingskennis, wordt nog in beperkte mate verworven ${ }^{1}$. Wanneer studenten na verloop van tijd in praktijkstages in aanraking komen met echte patiënten en hun problemen, zullen ze de pathofysiologische kennis waarover ze beschikken, voor zover van belang voor die klachten, in zijn volle omvang activeren. Dat verklaart waarom medische studenten in de eerste fase van hun contacten met patiënten zich zo vaak overspoeld voelen met mogelijke verklaringen voor de klachten waaruit het moeilijk kiezen is. Het verklaart ook waarom gevorderde studenten meer vragen stellen aan patiënten, meer lichamelijk onderzoek doen en meer labdata opvragen dan ervaren artsen. Zij activeren zoveel gedetailleerde kennis die om confirmatie vraagt, dat daarom 'intermediate' effecten optreden in allerlei expertise-gerelateerde taken (Schmidt, Boshuizen, \& Hobus, 1988). Echter, onder invloed van de toepassing van die kennis treedt 'encapsulatie' op. Schmidt en Boshuizen (1992) definiëren encapsulatie als een leermechanisme dat bestaat uit de voortschrijdende onderordening, of 'verpakking', van lagere orde begrippen en hun relaties in een kennisbestand onder een kleiner aantal concepten of proposities van hogere orde, die dezelfde verklaringskracht hebben. Met andere woorden, als studenten hun pathofysiologische kennis op een aantal patiënten met dezelfde of vergelijkbare ziekten toegepast hebben, zal niet alle (detail)kennis meer worden geactiveerd maar slechts een beperkt aantal sleutelbegrippen die hen in staat stelt een probleem op een meer 'grofkorrelige' wijze te begrijpen. Deze verandering in het kennisbestand leidt ertoe dat ze problemen sneller en accurater kunnen diagnostiseren en dat minder informatie nodig is om tot die prestatie te komen.

Parallel aan de encapsulatie van biomedische kennis vindt ziekte scriptvorming plaats. Studenten doen ervaringen op met bepaalde categorieën van ziektebeelden waarvan concrete patiënten de voorbeelden zijn. Die patiënten hebben allemaal een ziektegeschiedenis die tot de huidige ziekte geleid heeft. Ze vertonen ook allemaal een patroon van klachten en symptomen. En alhoewel er aanzienlijke variatie bestaat in de wijze waarop ziekte zich in een concreet individu manifesteert (wat de taak van een arts tot een moeilijke maakt), blijkt het toch mogelijk uit de ziektegeschiedenissen en symptomen en klachten een patroon te distilleren ${ }^{2}$. Dit patroon noemen Schmidt en Boshuizen in navolging van Feltovich en Barrows (1984) een ziekte script. Een ziekte script bestaat, zoals in de inleiding tot dit proefschrift al uiteengezet, uit contextuele kennis ('enabling conditions'), kennis van de disfunctie ('fault') en kennis van de symptomen en klachten die uit de disfunctie

\footnotetext{
${ }^{1}$ Dat is zelfs het geval in zogenaamde probleemgestuurde curricula waarin studenten vanaf het begin met patiëntproblemen geconfronteerd worden. Blijkbaar kan men klinische kennis niet goed verwerven als niet eerst de daarvoor relevant biomedische kennis verworven is.

2Distilleren is wellicht niet het juiste woord omdat het een bewust proces veronderstelt. Eerder is het zo dat artsen door ervaring en op basis van hun theoretische kennis de kenmerkende elementen van een bepaalde ziektecategorie leren zonder zich daarvan noodzakeliịk bewust te zijn of dat zelfs maar na te streven.
} 
voortvloeien ('consequences'). De oorspronkelijke biomedische kennis is in dit ziekte script geëncapsuleerd en dan met name in de fault en de consequences. Naar Schmidt en zijn collega's veronderstellen zijn het deze cognitieve structuren die geactiveerd worden bij het diagnostiseren van routineproblemen. Het is ook de snelle activatie van deze scripts in hun geheel die artsen en anderen doet spreken van patroonherkenning, de onmiddellijke waarneming van de 'Gestalt' van een bepaalde ziekte, de herkenning van de klachten en symptomen van een patiënt als een voorbeeld van een bepaalde ziektecategorie. Deze ziekte scripts zijn geabstraheerd van de directe ervaring en gefilterd door de interactie tussen kennis en ervaring. Het gaat om semantische kennis die bij activatie geïnstantieerd wordt met de specifieke kenmerken van de concrete patiënt die hier en nu gediagnosticeerd wordt. Brooks en zijn collega's (1991) veronderstellen dat daarnaast het geheugen concrete ervaring met een patiënt separaat als episodische elementen opslaat, in geïnstantiëerde vorm dus. Zij dragen empirisch materiaal aan waaruit blijkt dat artsen inderdaad gebruik maken van ervaringen met een concrete patiënt die eerder gezien werd bij de diagnostiek van een nieuwe patiënt. Het is echter onduidelijk of dit opereren op grond van episodische kennis regel dan wel uitzondering is 1.

Het onderzoek dat we in dit proefschrift beschrijven draagt op verschillende wijzen bij aan de verdere verheldering van de hier beschreven ontwikkelingsprocessen, in het bijzonder aan de onderbouwing van het idee van het ziekte script. In feite markeren de studies die we in dit proefschrift aan de orde stellen, de eerste pogingen om op empirische wijze de psychologische realiteit van deze cognitieve structuren aan te tonen. Hoewel het idee van ziekte scripts op grond waarvan artsen in routinegevallen opereren nu bijna gemeengoed is geworden binnen de gemeenschap van onderzoekers die in dit veld aktief zijn (Feltovich, 1992), was dat niet het geval toen we dit onderzoek begonnen, nu zeven jaar geleden. De toen overheersende visie was dat ervaren artsen een uitgebreider kennisbestand hebben dan personen met minder expertise in een domein en dat dit meer uitgebreide bestand artsen in staat stelde via zorgvuldig en 'diep' redeneren tot een juiste diagnose te komen (Lesgold, 1984). Patroonherkenning, nu algemeen gezien als hét kenmerk van echte expertise, werd toen beschouwd als een riskante bezigheid waartegen artsen zouden moeten waken.

Een eerste bijdrage van het in dit proefschrift beschreven onderzoek aan de theorievorming is dus het idee dat de kennis waarmee artsen in routinegevallen opereren, een scriptstructuur heeft en dat kennis georganiseerd in die scripts eerder klinischnarratief dan causaal-biomedisch van aard is. Interessant is dat ook in andere domeinen, zoals de meetkunde en de mechanica, bij experts schematische structuren zijn ontdekt die in termen van de regels van het betreffende vakgebied als betrekke. lijk globaal zijn te beschouwen, maar die veel contextuele cues bevatten (Elio \&

\footnotetext{
${ }^{1}$ Elke arts kent wel concrete patiënten met een bepaalde ziekte die hij/zij in het verleden behandeld heeft. Het is echter de vraag of die herinneringen ook werkelijk geactiveerd worden tijdens het diagnestiseren van een nieuwe patiënt. Vooralsnog lijkt dat beperkt te blijven tot ervaringen die op de een of andere wijze emotionerend waren, zoals foute diagnoses met noodlottige afloop of intense betrokkenheid bij het ziekteproces van een bepaalde patiënt (Hassebrock \& Prietula, 1990).
} 
Scharf, 1990; Koedinger \& Anderson, 1990). Blijkbaar reorganiseren experts, in response op de eisen die hun dagelijkse taak stelt, hun kennis in abstracte schema's die deels gecompileerde of geëncapsuleerde kennis bevatten, en wier activatie in hoge mate context-sensitief is.

Een tweede bijdrage van het onderzoek is de aandacht die het heeft gevestigd op het grote belang van de context waarin een ziekte optreedt voor de diagnostiek van de ziekte. Contextuele cues maken, zo blijkt uit de studie die hier gepresenteerd is, deel uit van de schema's die experts gebruiken om hun wereld te begrijpen. Het onderzoek sluit daarmee aan op de recent opgekomen cognitief-psychologische stroming die men 'situated cognition' noemt (Brown, Collins \& Duguid, 1989). Deze benadering vraagt aandacht voor het feit dat menselijke cognitie sterk gebonden is aan situaties waarin die cognitie functioneel is. Eén van de consequenties van die opvatting is dat te leren kennis en vaardigheden zoveel mogelijk dienen plaats te vinden in de situatie waarin die kennis en vaardigheden moeten worden toegepast.

Een derde bijdrage is dat men ziekte scripts inderdaad op een bevredigende wijze kan beschrijven met Feltovich en Barrows' onderverdeling in enabling conditions, fault en consequences. De studie die we in hoofdstuk 6 bespreken, laat zien dat door artsen gegenereerde patiëntbeschrijvingen betrekkelijk moeiteloos zijn onder te brengen in deze categorieën. Diezelfde studie en een vervolgstudie van Custers (1993) laten echter ook zien dat er reden is het ziekte scriptconcept uit te breiden met een element dat betrekking heeft op de behandeling van de ziekte die de patiënt presenteert. Proefpersonen genereerden spontaan, want ongevraagd, informatie met betrekking tot de aard van de acties die ze ondernemen wanneer ze met een patiënt van de aangeboden categorie geconfronteerd worden. Achteraf gezien is het niet helemaal onlogisch dat ook handelingskennis van een ziekte script deel uitmaakt omdat diagnose en plan in de dagelijkse praktijk zo nauw verbonden zijn.

Verder heeft dit onderzoek een nieuwe, empirische, en experimentele methode opgeleverd om de kennisstructuren van artsen te onderzoeken. Dat betekent dat expertise-onderzoek zich niet meer hoeft te beperken tot quasi-experimentele vergelijking van groepen met een verschillend niveau van expertise, zoals tot nu toe gebruikelijk was. Experimentele manipulatie van variabelen die van theoretisch van belang worden geacht, maakt het mogelijk veel gedetailleerder te gaan begrijpen wat expertise is en hoe het zich ontwikkelt. Het is de Maastrichtse groep geweest, die dergelijke manipulaties in het expertise-onderzoek als eerste introduceerde (Hobus, et al., 1987; Schmidt, et al., 1987). Dat voorbeeld heeft inmiddels op beperkte schaal navolging gevonden (e.g. Norman, Brooks, Allen \& Rosenthal, 1988). Daarnaast lijkt de methode die we in hoofdstuk 6 gebruiken, heel geschikt om ziekte scripts rechtstreeks te eliciteren.

Een andere vermeldingswaardige bijzonderheid van dit onderzoek is dat we binnen het veld van de huisartsgeneeskunde een cognitief psychologische benadering van het huisartsgeneeskundig handelen, zonder meer als een uitzondering kunnen beschouwen. Het huisartsgeneeskundig onderzoek is de laatste jaren sterk gekenmerkt door epidemiologische en besliskundige benaderingen. Dit komt ondermeer 
naar voren in door NWO gesubsidieerd onderzoek. Dergelijk onderzoek kan een belangrijke bijdrage leveren aan de specifieke kennis over ziekten in de huisartsgeneeskundige setting. Indirect zal dergelijke kennis daarom tevens een bijdrage leveren aan de verbetering van huisartsgeneeskundig diagnostisch handelen doordat huisartsen zich meer bewust worden van specifieke kenmerken van de 'eerstelijns-pathologie'. Echter, in epidemiologisch onderzoek ligt ook vaak de verwachting besloten dat de resultaten direct toepasbaar zijn voor de huisarts in de spreekkamer. Zo zou kennis omtrent a priori kansen van ziekten bij een bepaalde klacht direct van invloed kunnen zijn op het denken van de huisarts tijdens het consult (Knottnerus, 1986). Mede met het soort onderzoek zoals we in dit proefschrift beschrijven, ontstaat twijfel of een dergelijke verwachting haalbaar zal blijken. In veel onderzoek naar de menselijke mogelijkheden om met getallen om te gaan, blijkt namelijk het feitelijk denken nogal eens af te wijken van wat besliskundigen wenselijk achten.(Berwick, Fineberg, \& Weinstein, 1981) Ook kwantitatieve schattingen van artsen over de kans op bepaalde ziekten bij een patiënt zijn vaak bezijden de waarheid. Dit bleek ondermeer ook in niet gepubliceerde analyses van de resultaten in experiment I (Hobus, et al. 1987). We vroegen de proefpersonen in dit onderzoek (18 ervaren huisartsen en 17 basisartsen) de meest waarschijnlijke hypothese te noemen en in percentages aan te geven hoe waarschijnlijk zij het achtten dat hun geopperde hypothese overeen zou komen met de definitieve diagnose van de casus. Theoretisch staat een dergelijke schatting in hoge mate onder invloed van de gebruikte kennis over a priori kansen, maar tevens is die een uiting van onzekerheidgevoelens. Aangezien de ervaren huisartsen in ons onderzoek meer gebruik bleken te maken van de risicofactoren( ze maken immers gebruik van context informatie), verwacht men in deze groep gemiddelde hogere kansschattingen dan in de groep van de onervaren basisartsen. In een variantie-analyse echter blijkt dit verwachte verschil in kansschattingen tussen de ervaren en onervaren artsen niet aanwezig. Een verklaring hiervoor zou kunnen zijn dat de huisartsen meer stress ondervonden tijdens de experimentele taak of onzekerder waren dan de basisartsen en daarom hun kansschattingen aan de lage kant hielden. Echter, ook een variantie-analyse waarbij ervaren stress en onzekerheidgevoelens als covariabelen werden opgevoerd (waardoor hiervoor gecorrigeerd wordt) liet geen verschillen zien tussen de beide onderzoeksgroepen. Dus ondanks het bewezen gebruik van relevante contextuele informatie door huisartsen, betekent dit niet automatisch dat zij daardoor kwantitatieve afwegingen maken met aan risicofactoren verbonden a priori kansen. Waarschijnlijik maken ervaren huisartsen op andere wijze gebruik van risicofactoren, namelijk dat het al dan niet aanwezig zijn van een risicofactor van meer belang is dan het gewicht waarmee deze risicofactor de aanwezigheid van een bepaalde ziekte voorspelt. Terugvertaald naar de vraag welke bijdrage epidemiologisch onderzoek kan hebben voor de vroege huisartsgeneeskundige diagnostiek, betekent dit dat het vinden van nieuwe risicofactoren meer zal bijdragen aan een verbeterde diagnostiek dan het precies vaststellen van de voorspellende waarden van al bekende risicofactoren.

Uiteraard produceert onderzoek veelal meer vragen dan het beantwoordt. Dat is ook met het onderhavige het geval. De eerste vraag die zich opwerpt is of ervaren artsen selectief aandacht geven aan bepaalde aspecten van de aangeboden contextuele 
informatie. Is het zo dat sommige typen context betekenisvoller zijn voor de arts, los van de vraag wat de klacht is waarmee de patiënt komt? We kregen bijvoorbeeld de indruk dat de medicatie van een patiënt 'as such' aanleiding geeft tot specifieke diagnostische overwegingen. Dit komt naar voren in hoofdstuk 5 waar experts contextuele informatie over medicatie beter onthielden als we de groene kaart in plaats van na de klacht voor de klacht presenteerden. Zou er daarom misschien nog meer contextinformatie zijn die altijd de aandacht van artsen trekt, omdat ze een aigemene vlagfunctie vervult? (met vlagfunctie bedoelen we dat de betreffende informatie altijd naar iets medisch relevants verwijst) Een dergelijke vraag kunnen we echter niet beantwoorden met de voor dit proefschrift gebruikte methoden. Daarvoor zou het nodig zijn dezelfde informatie op sequentiële wijze met een connputer aan te bieden en leestijden te meten. Een andere methode die een antwoord kan geven op de gestelde vraag is het meten van oogbewegingen bij het verwerken van informatie. Beide benaderingen zullen kunnen bijdragen aan een meer gedifferentieerd beeld van de rol van de context bij de activatie van diagnostische hypothesen.

Tot nu toe hebben we het concept van een ziekte script benaderd alsof er voor ellke ziekte die een arts in voldoende mate gezien heeft een ziekte script in zijn geheugen aanwezig is. Belangrijker nog: we hebben wellicht de indruk gewekt dat die ziekte scripts een vergelijkbaar niveau van abstractie hebben en in principe nevengeschikt zijn. Dit is waarschijnlijk niet zo. Vermoedelijk, onder andere op basis van kennis uit andere domeinen (Elio \& Scharf, 1990), worden scripts op verschillende niveaus van abstractie op de een of andere manier hiërarchisch geordend. Men zou zich kunnen voorstellen dat er niet alleen een ziekte script bestaat voor acute bacteriële endocarditis maar ook een voor hartziekten waarbij sprake is van ontsteking. Het laatste is uiteraard meer abstract dan het eerste omdat zo'n hartziekte script behalve acute bacteriële endocarditis ook nog een aantal andere hartziekten, zoals het endocarditis lenta of epicarditis reumatica zou onderordenen. Deze hiërarchische structuur, wellicht verlopend van scripts voor systeemafwijkingen tot episodische representaties van concrete patiënten, is waarschijnlijk omdat artsen bij de sequentiële presentatie van informatie over een patiënt vaak eerst met een, naar het lijkt, zeer algemeen script komen aanzetten voordat verdere informatie meer specifieke scripts activeert. In een studie van Joseph en Patel (1990) bijvoorbeeld, waarbij informatie over een patiënt sequentieel werd aangeboden op een computerscherm en proefpersonen hardop moesten denken, produceerden de meeste experts in eerste instantie zinnen als: "Iets met het hart" of "Iets met de maag", voordat zij op grond van verdere informatie meer specifieke hypothesen formuleerden. Die eerste hypothesen, namelijk dat de gegeven informatie zou kunnen wijzen op problemen gerelateerd aan het hart, of juist: aan de maag, suggereren dat experts van meer globale scripts naar meer specifieke scripts gaan als het probleem van de patiënt zich verder ontrolt. Verwacht mag worden dat zich op elk van die niveaus van abstractie een script bevindt dat suggesties doet voor verder anamnese of lichamelijk: onderzoek. Ook hier geldt dat verder onderzoek naar de organisatie vain scripts in het: geheugen van ervaren artsen van groot belang is voor een beter begrip van de rol van scripts in de diagnostiek. 
Een laatste vraag die zich voordoet, heeft betrekking op wanneer de verschillende elementen van een script geleerd worden. Schmidt en Boshuizen (1993) benadrukken sterk de rol van praktische ervaring bij het leren van contextuele informatie, een positie die we ook in dit proefschrift innemen. De implicatie van dit standpunt is dat tijdens het theoretische gedeelte van de medische opleiding contextuele informatie slechts beperkt geleerd wordt. Die informatie zit verborgen in cursussen op het terrein van de epidemiologie, de medische psychologie, de medische sociologie, de sociale verzekeringskunde en andere vakken die zich richten op de context waarin ziekte optreedt. Die wordt tijdens de studie onvoldoende direct gerelateerd aan de ziektebeelden die men leert. Dit zou verklaren waarom onervaren artsen in experimenten I, II, en III zo weinig met die informatie deden. Deze opvatting is ook overeenkomstig het feit dat diagnostische accuratesse zozeer gebonden blijkt aan het aantal jaren praktijkervaring, zoals in hoofdstuk 4 beschreven. Contextuele informatie wordt pas in de intensieve interactie met patiënten geleerd, zo suggereren deze bevindingen. Aan de andere kant kunnen we niet ontkennen dat men in het medisch curriculum wel degelijk aandacht besteedt aan deze onderwerpen. Dit zou erop kunnen duiden dat contextuele informatie wel geleerd wordt tijdens de opleiding, maar in het begin nog niet goed geïntegreerd is met de rest van het ziekte script. Pas in interactie met de praktijk neemt de toegankelijkheid van contextuele kennis toe en vindt integratie plaats. Onderzoek zou zich op deze scholing-versuservaring hypothese moeten richten.

\section{Implicaties voor het medisch onderwijs}

Het is altijd moeilijk met de kennis van hoe de wereld in elkaar zit uitspraken te doen hoe studenten zouden moeten leren teneinde uiteindelijk als 'excellente professionals' een nuttige taak te vervullen in de samenleving. Dat geldt in het bijzonder voor de theoretische noties van Schmidt en Boshuizen die door de onderhavige studies mede ondersteund worden. Deze noties hebben een duidelijk rijpingskarakter; de ontwikkeling van expertise wordt in sterke mate gerelateerd aan de hoeveelheid praktische ervaring die iemand opdoet, en opdoen van ervaring is niet iets dat door slimme onderwijsmaatregelen in sterke mate valt te bevorderen. Dat moet rijpen zoals goede wijn. Niettemin lijkt het mogelijk uit onze bevindingen een aantal suggesties voor de verbetering van het medisch onderwijs af te leiden.

In de eerste plaats lijken er redenen te zijn biomedische en klinische kennis zoveel mogelijk op een geïntegreerde wijze aan te bieden. Daar bedoelen we mee dat onderwerpen uit de klinische- en basisvakken, die met elkaar te maken hebben, in de tijd gezien naast elkaar gedoceerd moeten worden. De nu nog op veel plaatsen bestaande scheiding in het curriculum, waar in de eerste twee jaar de basisvakken en in de volgende twee jaar de klinische vakken gedoceerd worden, dient te worden opgeheven. Wij nemen aan dat wanneer de gedoceerde fysiologie, anatomie, biochemie en pathologie van een systeem op elkaar betrokken worden, het ontstaan van cognitieve structuren gestimuleerd wordt waarin die onderwerpen ook op een zinvolle manier geïntegreerd zijn. De student integreert dan niet zelf met het risico dat de integratie niet of op de verkeerde wijze tot stand komt, maar geschiedt op een manier waarbij docenten hun studenten behulpzaam kunnen zijn. De uitkomsten 
van ons onderzoek laten zien dat rijke en prototypische ziekte scripts een belangrijke rol spelen in diagnostische effectiviteit. Het lijkt daarom aan te bevelen de te verwerven kennis te groeperen rondom dergelijke prototypen. Epidemiologische en andere contextueel belangrijke kennis, zoals kennis over de invloed van levensstijl en medicatie op gezondheid, de rol van sociaal-economische factoren enzovoorts, zou daarbij niet in aparte cursussen maar als integraal onderdeel van een dergelijk patiëntgecentreerd curriculum aangeboden worden.

Speciaal vanuit het onderwijs aan toekomstige huisartsen komt de vraag naar voren of het intensief gebruik van contextuele informatie in de eerste diagnostische fase geleerd zou kunnen worden. Het lijkt geen onmogelijkheid om de gewenste. veranderingen in de kennisstructuur, die daarvoor noodzakelijk is, op zijn minst te versnellen onder invloed van gerichte oefening. Bij een nadere beschouwing van de resultaten in dit proefschrift valt, zoals uit het navolgende zal blijken, al het een en ander af te leiden.

In experiment III hebben we het informatieaanbod van de casus gemanipuleerd door contextuele informatie hetzij voor, hetzij na de klacht te geven. Uit de resultaten komt duidelijk naar voren dat de individuele contextuele factoren (leeftijd, geslacht, medicatie, gegevens betreffende vroegere ziekten, operaties, beroep, etc.) zich onderling onderscheiden in de mate waarin de ervaren versus de onervaren groep artsen ze tijdens de diagnostische taak gebruikt. Dit betekent dat bepaalde enabling conditions als het ware moeizamer hun plaats in de aanwezige ziekte scripts verwerven dan andere. Zo blijkt bijvoorbeeld dat ervaren huisartsen ten opzichte van de onervaren artsen informatie over medicatie of over vroegere ziekte-episoden veel intensiever gebruiken dan bijvoorbeeld leeftijd en geslacht. Het effect van medicatie-informatie is waarschijnlijk het gevolg van het onderliggende concept dat inherent verbonden is aan farmacologische stoffen, namelijk: 'een-patiënt-weer-gezond-maken'. Uit dit onderzoek blijkt dat artsen door ervaring; leren dat medicijnen weliswaar bedoeld zijn om patiënten beter te rnaken, maar ook meer dan eens aanleiding geven tot klachten. Een dergelijke besef zal waarschijnlijk wel aanwezig zijn bij onervaren artsen, maar komt blijkbaar pas onder invloed van ervaring naar voren als zijnde van diagnostisch belang!

Aldus kan men constateren dat in het ziekte script de kennis over medicatie bij ervaren huisartsen steeds meer 'naar voren' komt. Immers, gebruik van kennis omtrent farmacologische actieve stoffen is in het begin van een medische carrière vooral belangrijk in de afronding van een ziekte script: na het stellen van een diagnose volgt daaruit een therapeutische handeling. Onder invloed van dagelijkse patiëntencontacten gaat kennis over bijwerkingen van medicijnen als fault een belangrijke rol spelen om consequences van bepaalde ziekte scripts te begrijpen. Inherent hieraan verwerven de medicatiegegevens van een patiënt een belangrijke plaats vooraan in het ziekte script, namelijk in het compartiment enabling conditions. Het bevorderen van deze 'shift' in de ontwikkeling van ziekte scripts bij 'onervaren' (huis-)artsen zou dus een zinvol onderdeel kunnen uitmaken van de opleiding tot huisarts. Dit zou gericht bewerkstelligd kunnen worden middels vergroting van kennis over bijwerkingen bij veel toegepaste eerste-lijns 
medicijnen. Verder kan het veelvuldig aanreiken van casus waarin bijwerkingen van geneesmiddelen een cruciale rol spelen in de diagnostiek, de onervaren huisarts meer alert maken voor het toepassen van geneesmiddelenkennis in een vroeg stadium van de diagnostiek. Op soortgelijke wijze kunnen we mogelijk ook het gevoel voor het belang van voorafgaande ziekte-episoden voor de interpretatie van de actuele klacht aangewakkeren.

\section{Implicaties voor de huisartsgeneeskunde}

Met de resultaten van experimenteel wetenschappelijk onderzoek die we in dit proefschrift beschrijven, komen naar onze mening een aantal wezenlijke kenmerken van de huisartsgeneeskundige diagnostiek naar voren. In geen enkele andere discipline van de gezondheidszorg kan een arts geconfronteerd worden met een zó grote diversiteit aan ziekten. In principe kan de huisarts met iedere denkbare ziekte in aanraking komen. Dit zijn er bij benadering 9000 (Lamberts, 1991). Afgaande op de ICPC lijst die gebruikt wordt ter registratie van ziekten in de huisartspraktijk, bedraagt het aantal te registreren diagnostische categorieën ongeveer 646; hiervan worden er ongeveer 400 regelmatig geregistreerd (vaker dan eenmaal per 1000 patiënten per jaar). Daarbij dient men zich te realiseren dat in een diagnostische categorie meer dan één ziekte gerubriceerd wordt. Om met een groot en gevarieerd aanbod diagnostisch uit de voeten te kunnen, ontwikkelen zich ons inziens de mechanismen en de typische veranderingen in de medische kennis zoals in dit proefschrift beschreven worden.

Misschien kan men zichzelf de vraag stellen of de evolutie van medische kennis zoals we in dit proefschrift bij ervaren huisartsen zien ook bij beoefenaren van andere medische disciplines kan worden aangetroffen. Dat wil zeggen de vraag of kennis over enabling conditions van ziekten proportioneel steeds belangrijker wordt in de patiëntenkennis. Door de laagdrempelige toegang tot de huisarts met als gevolg een groot aanbod van alle mogelijke aandoeningen (vaak in het vage vroege stadium), is de huisarts min of meer gedwongen zijn toevlucht te nemen tot maximaal gebruik van alle makkelijk voorhanden zijnde informatie om een goede inschatting te maken van de ernst en aard van de aandoening. Bij 'kleinere' specialismen zoals in de Keel- Neus- en Oor - of de Oogheelkunde is er sprake van een beperkt aantal ziektebeelden waardoor desbetreffende specialisten binnen het aantal diagnostisch mogelijkheden een 'kleinere' selectiestap hoeven te maken. Daarbij worden zij nog eens gesteund door 'harde' resultaten van specialistische onderzoek. Het is dan ook minder waarschijnlijk dat een KNO- of oogarts intensief gebruik moet maken van gegevens uit de context van de klacht om tot een diagnose te komen. Het ontstaan van een kennisstructuur met context-rijke illness scripts zal daardoor niet bevorderd worden. Algemene specialisten echter zoals internisten en neurologen die evenals huisartsen geconfronteerd worden met een grote diversiteit aan ziektebeelden zouden mogelijk wel onder invloed van ervaring 'huisartsgeneeskundige' veranderingen in hun kennisstructuur laten zien. Echter, routines en protocollen bepalen sterk hun werkwijze (Gerritsma \& Smal, 1982) en deze hebben op hun beurt vaak weer de klacht als ingang. Daardoor is specialistische 
diagnostiek primair klacht-georiënteerd. Daamaast verwacht men van een specialist dat die ook zeldzame aandoeningen diagnostiseert. Door al in de allereerste fase van de diagnostiek rekening te houden met contextuele informatie zal de specialist enerzijds afwijken van protocollen en routines en anderzijds statistisch gezien een grotere kans maken een zeldzame aandoening te missen. Al met al lijkt het daarom onwaarschijnlijk dat een specialist in de loop van zijn carrière meer en meer context-gestuurd gaat denken of dat zijn gevoeligheid voor contextuele informatie drastisch toeneemt.

In dit proefschrift komt nog een ander wezenlijk facet van hulpverlening naar voren waarin de huisarts zich onderscheidt van de specialist, namelijk de continuilteit van zorg. Continuïteit van zorg wordt ondermeer gedefinieerd als "het plaatsen van klachten, aandoeningen en hulpvragen in de levenslijn van de patiënt, rekening houdend met ontwikkelingen binnen diens directe sociale omgeving en gelet op de gehele praktijk populatie" (Grol et al., 1987). Deze omschrijving heeft een sociologische invalshoek. Het aspect continuïteit zoals in dit proefschrift naar voren komt, is echter van meer psychologische aard. Meer specifiek: de cognitief-psychologische aspecten van de eerste momenten van een huisarts-patiënt contact. Zoals wel duidelijk is, heeft continuilteit in de huisarts-patiënt relatie tot gevolg dat de huisarts over veel (medische en niet-medische) achtergrondinformatie beschikt op het moment dat de patiënt zijn actuele probleem presenteert. De resultaten van dit proefschrift laten meerdere malen zien dat dergelijke kennis over achtergrondgegevens steeds beter geïntegreerd raakt in al bestaande ziektekennis omtrent pathofysiologie, symptomatologie en dergelijke. De beschreven veranderingen in de kennisstructuur van ervaren huisartsen zijn dus ook op te vatten als een direct effect van' continuiteit van zorg'. Daarmee krijgt het begrip continuiteit van zorg een nadere invulling vanuit cognitief psychologisch perspectief en bewijst op de huisartsgeneeskundige diagnostiek belangrijke effecten te hebben.

\section{Implicaties voor de kwaliteitsbevordering in de huisartsgeneeskunde}

De huidige benadering in kwaliteitsbevordering in de huisartsgeneeskunde kenmerkt zich door de ontwikkeling van standaarden. Standaarden beschrijven een deel van het diagnostisch en therapeutisch handelen van de huisarts zoals dat gegeven de stand van wetenschap en volgens een groep deskundigen idealiter dient te verlopen. Het idee van standaardisatie is eigenlijk afkomstig uit de industrie waar men door segmentatie en optimalisatie van produktieprocessen verbetering van de kwaliteit van het produkt kan bereiken. De voorstanders van protocolisering in de huisartsgeneeskunde denken dat de voorgeschreven handelingen van een protocol, bijvoorbeeld in de vorm van bepaalde noodzakelijke diagnostische vragen, spontaan gedrag van huisartsen corrigeert (Sips, 1986). Door zich aan een voorgeschreven protocol te houden zou een huisarts daarmee bijvoorbeeld diagnostische dwaalwegen kunnen vermijden en zodoende zijn diagnostiek verbeteren. Een eerste bezwaar is dat de gehele huisartsgeneeskundige diagnostiek door de aard moeilijk in protocollen te vangen is, ondermeer vanwege de reeds beschreven diversiteit en het onrijpe karakter van ziektebeelden. Verder kan men 
zich afvragen of een telkens in vorm veranderend en adaptief fenomeen als het diagnostisch denken van huisartsen een zelfde benadering verdraagt als de industriële produktie van goederen.

Tot op heden zijn protocollen beschikbaar voor een beperkt aantal ziektebeelden. Er zijn op het moment van het schrijven van dit hoofdstuk een 30-tal standaarden gepubliceerd waarvan 27 handelen over diagnostiek. De invloed op de praktijkvoering is mogelijk gering omwille van vele nog niet geheel opgehelderde redenen (Grol, 1989; Grol, Kistemaker \& Hanrahan-Cahuzak, 1990; Grol, Tielens, Mokkink \& Zwaard, 1988; Grol \& Zwaard, 1989; Kosecoff, Kanouse, Rogers, McCloskey, Winslow \& Brook, 1987). Een van de redenen zou kunnen zijn dat ze niet voldoende aansluiten bij het 'van nature' voorkomende denkproces van huisartsen. Inzicht in de factoren die diagnostische hypothesevorming beïnvloeden is daarom van belang om de richtlijnen voor diagnostisch handelen meer te laten aansluiten op de feitelijke manier van denken. Dit zal de acceptatie en uitvoering van richtlijnen door huisartsen bevorderen (Grol, et al., 1988; Kanouse \& Jacoby, 1988). In het veranderingsmodel, zoals diverse instanties betrokken bij de invoering van protocollen onder de Nederlandse huisartsen dat voorstaan (Grol, 1988), wordt echter helaas weinig aandacht geschonken aan de manier waarop medische kennis van huisartsen van invloed is op hun diagnostisch denken en handelen. Daarentegen is er, zoals reeds aangegeven, een sterke invloed van de besliskundige benadering hetgeen ondermeer tot uitdrukking komt in het streven richtlijnen zoveel mogelijk te baseren op beschikbare epidemiologische kennis. Dit is op zichzelf een goed streven, maar dergelijke kennis is in de huisartsgeneeskunde vooralsnog echter weinig voorhanden. Zo weinig zelfs dat men zich kan afvragen in hoeverre een benadering die meer rekening houdt met de cognitieve aspecten van het huisartsgeneeskundig handelen, momenteel niet vruchtbaarder zal zijn. Daarvoor is een aantal argumenten aan te voeren.

Het eerste heeft betrekking op de aard van de informatie die wordt aangedragen. Bij publicatie van een Nederlands Huisarts Genootschap standaard wordt deze uitgebreid toegelicht in Huisarts en Wetenschap in termen van onderliggende motieven en kennis. Het is echter niet duidelijk in hoeverre deze toelichting voldoende is om door huisartsen vruchtbaar toegepast te kunnen worden binnen de aangegeven handelingsrichtlijnen van de standaard. Naarmate de nieuwe kennis minder goed aansluit bij de kennis die in de praktijk wordt toegepast, is de kans kleiner dat deze in praktijksituatie kan worden geactiveerd en dus het handelen in de gewenste richting kan beïnvloeden. Dit zou de slechte 'fit' kunnen verklaren tussen feitelijk handelen en voorgeschreven richtlijnen (Rethans, 1987; Rethans, Sturmans, Drop, van der Vleuten \& Hobus, 1991). Het is dan ook niet zozeer de vraag in hoeverre huisartsen onkundig, onwillig of ongemotiveerd zijn standaarden praktisch toe te passen (Heerdink, Kaptein, \& Grol, 1990; Grol, et al. 1990), maar misschien meer nog in hoeverre een standaard voldoende overeenkomt met werkelijke mentale en praktische dimensies van het diagnostisch proces. Alleen daadwerkelijk in de praktijk toepasbare protocollen kunnen de huidige variatie in het handelen verminderen en mogelijkheden bieden tot kwaliteitsbevordering. Inzicht in de factoren die van 
invloed zijn op het geschetste probleem en daarmee in de cognities en het feitelijk gedrag van huisartsen is daarvoor onontbeerlijk.

In dit proefschrift richten we daartoe meer specifiek de aandacht op de kennisstructuren die bij ervaren huisartsen verantwoordelijk zijn voor het feit dat zij betere diagnostische beginhypothesen ontwikkelen dan onervaren artsen. Ondermeer blijkt de kennis zoals die gestructureerd wordt in ziekte scripts van doorslaggevende betekenis in het herkennen van relevante contextuele informatie hetgeen weer van essentieel belang is in de vorming van kwalitatief goede hypothesen. Vanuit dit gegeven bezien zouden standaarden in de opbouw van richtlijnen rekening moeten houden met het feit dat contextuele informatie voor de eerste beslismomenten van het consult mogelijk een belangrijkere rol speelt dan de verdere klachtuitdieping of het lichamelijk onderzoek.

Dit laatste brengt ons op een tweede bezwaar. Een studie van Hofstra et al. (Hofstra, Boshuizen, Grol, Hobus, Meijer, \& Jacobs, 1993) laat namelijk zien dat de aansluiting van beschikbare standaarden op het kennissysteem vooralsnog te wensen overlaat. Hierin werd de kennisstructuur van 42 huisartsen (18 ervaren huisartsen en 24 gevorderde huisartsen in opleiding) onderzocht op de aanwezigheid van specifieke patiëntcategorieën ${ }^{1}$ binnen het ziektebeeld van 7 NHG standaarden (Diabetes Mellitus type II, Urineweginfecties, Enkeldistorsie, Otitis Media Acuta, Acute Keelpijn, Oogheelkundige Diagnostiek, Perifeer Arterieel Vaatlijden). Uit de resultaten van deze studie blijkt alleen de standaard Urineweginfecties inhoudelijk dezelfde patiëntentypen te onderscheiden als die van de deelnemende artsen. In slechts 3 van de 7 standaarden (Acute Keelpijn, Urineweginfecties, Otitis Media Acuta) geeft men meer specifieke richtlijnen aan indien er naast de klacht bepaalde contextuele factoren aanwezig zijn zoals een bepaalde voorgeschiedenis of geslacht. De deelnemende huisartsen echter, noemen bij iedere standaard tussen de 2 à 4 patiënttypen en geven daarbij per type 1-4 specifieke problemen of beslismomenten aan. De genoemde patiënttypen zijn vooral gebaseerd op leeftijd en geslachtskenmerken, soms met aanduidingen die betrekking hebben op voorgeschiedenis, beroep en/of hobby.

Aangezien na dit onderzoek nog diverse nieuwe standaarden het licht zagen hebben we nogmaals een globale analyse verricht van alle tot mei 1993 verschenen standaarden met als doel het aandeel van contextuele informatie op de opbouw van richtlijnen nader te bestuderen.

Van de 31 geanalyseerde standaarden (zie tabel 7.1) hadden er 27 mede betrekking op diagnostische handelingen. In 17 van deze 27 standaarden wordt melding gemaakt van patiëntentypen.

\footnotetext{
${ }^{1}$ Patiëntcategorieën en patiënttypen zijn vergelijkbaar met de prototypische ziekte scripts in de kennis van huisartsen over een bepaalde aandoening of klacht zoals we die in hoofdstuk 6 onderzocht hebben. Zowel patiënttypen als prototypische ziektescripts zijn een verzameling kenrnerken (inclusief de contextuele factoren) die de patiënt typeren vanuit een oogpunt van differentiaal diagnostische of therapeutische overwegingen.
} 
Tabel 7.1: Tot mei 1993 verschenen standaarden (lege velden hebben betrekking op niel- diagnostische standaarden, en zijn daarom niet betrokken in de analyse)

\begin{tabular}{|c|c|c|c|c|c|}
\hline Titel standaarden & $\begin{array}{l}\text { Diagnose } \\
\text { richtlijnen? }\end{array}$ & $\begin{array}{l}\text { Vermelding } \\
\text { patiënttypen? }\end{array}$ & $\begin{array}{l}\text { Diagnostische } \\
\text { patiënttypen? }\end{array}$ & \begin{tabular}{|l|} 
Geen type: \\
Wel contexi?
\end{tabular} & $\begin{array}{l}\text { Geen Context } \\
\text { of summier: }\end{array}$ \\
\hline $\begin{array}{l}\text { M } 1 \text { Diabetes Mellitus } \\
\text { Type II }\end{array}$ & ja & nee & n.v.t. & nee & $\overline{j a}$ \\
\hline M 2 Orale Anticonceptie & nee & 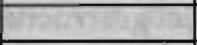 & & D & 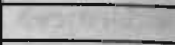 \\
\hline M 3 (Dreigende) Miskraam & ja & nee & n.v.t. & +4 & ja \\
\hline M 4 Enkeldistorsie & ja & nee & n.v.t. & ja & ja \\
\hline M 5 Urineweginfecties & ja & ja & ja & n.v.t. & nee \\
\hline M 6 Cervixuitstrijken & ja & 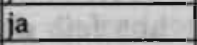 & nee & n.v.t. & nee \\
\hline M 7 Mammografie & ja & ja & nee & n.v.t. & nee \\
\hline M 8 Schouderklachten & ja & $\begin{array}{l}\text { ja; context } \\
\text { afw. }\end{array}$ & ja & nee & ja \\
\hline M 9 Otitis Media Acuta & ja & ja & nee & n.v.t. & ja \\
\hline \begin{tabular}{|l|}
$\begin{array}{l}\text { M10 Problematisch alco- } \\
\text { holgebruik }\end{array}$ \\
\end{tabular} & ja & nee & n.v.t. & ja & nee: \\
\hline M11 Acute Keelpijn & ja & ja & nee & n.v.t. & ja \\
\hline $\begin{array}{l}\text { M12 Oogheelkundige } \\
\text { Diagnostiek }\end{array}$ & ja & ja & ja & n.v.t. & nee \\
\hline $\begin{array}{l}\text { M13 Perifeer Arterieel } \\
\text { Vaatlijden }\end{array}$ & ja & ja & nee & n.v.t. & nee \\
\hline M14 Het Spiraaltje & nee & & & 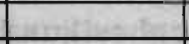 & \\
\hline M15 Acne Vulgaris & ja & nee. & n.v.t. & ja & ja \\
\hline M16 Ulcus Cruris Venosum & ja & nee & n.v.t. & ja & nee: \\
\hline M17 Hypertensie & ja & nee & n.v.t. & ja & nee? \\
\hline $\begin{array}{l}\text { M18 Otitis Media met: } \\
\text { Effusie bij Kinderen }\end{array}$ & ja & ja & nee & n.v.t. & ja \\
\hline M19 Migraine & ja & nee & n.v.t. & ja & nee: \\
\hline M20 Cholesterol & ja & ja & nee & n.v.t. & nee \\
\hline M21 Dementiesyndroom & ja & ja & nee & \begin{tabular}{|l|l|} 
n.v.t. \\
\end{tabular} & nee \\
\hline $\begin{array}{l}\text { M22 Bloedonderzoek bij } \\
\text { Verdenking op } \\
\text { Leveraandoeningen } \\
\end{array}$ & ja & ja & ja & n.v.t. & nee \\
\hline $\begin{array}{l}\text { M23 Slapeloosheid en } \\
\text { Slaapmiddelen }\end{array}$ & ja & ja & ja & n.v.t. & nee \\
\hline M24 Astma bij Kinderen & ja & ja & ja & n.v.t. & net: \\
\hline M25 Subfertiliteit & ja & nee & n.v.t. & ja & nex: \\
\hline $\begin{array}{l}\text { M26 Cara bij Volwassenen: } \\
\text { Diagnostiek }\end{array}$ & ja & nee & n.v.t. & $j a$ & nee: \\
\hline $\begin{array}{l}\text { M27 Cara bij Volwassenen: } \\
\text { Behandeling }\end{array}$ & nee & n.v.t. & n.v.t. & n.v.t. & n.v.t. \\
\hline M28 Vaginaal Bloedverlies ij & ja & ja & ja & n.v.t. & nee \\
\hline M29 Kinderen met Koorts & ja & ja & ja & n.v.t. & nee \\
\hline M30 Varices & ja & ja & ne: & n.v.t. & nee \\
\hline $\begin{array}{l}\begin{array}{l}\text { M31 Functiestoornisssen van j } \\
\text { de Schildklier }\end{array} \\
\end{array}$ & ja & nee & n.v.t. & ja & nee \\
\hline
\end{tabular}

Het feit dat er onderscheid is in patiëntentypen binnen een standaard heeft voornamelijk implicaties voor het beleid of het therapeutisch handelen en niet zozeer voor de diagnostiek. Bijvoorbeeld het onderscheid bij de standaard otitis media 
acuta in: kinderen jonger dan 6 maanden, tussen 6 maanden en 2 jaar, ouder dan 2 jaar en kinderen met recidiverende otitis media acuta heeft gevolgen voor de termijn waarin men kinderen moet teruggezien en de snelheid waarmee antibiotica gegeven moeten worden.

Slechts in 8 standaarden heeft het onderscheid in patiënttypen gevolgen voor de diagnostiek. Behalve bij standaard M8 is daarbij steeds sprake van beïnvloeding door de aanwezigheid van contextuele informatie in het patiënttype ${ }^{1}$. In de richtlijnen voor astma bij kinderen (M24) bijvoorbeeld makt men onderscheid tussen: kinderen $<1$ jaar, I-5 jaar of $>5$ jaar aangezien in deze leeftijdsgroepen astma zich meestal met verschillende symptomatologie presenteert namelijk: 'volzitten', hoesten 's nachts of kortademigheid bij inspanning. Ook bij deze 'diagnostische patiënttypen' is het onderscheid tevens van belang voor de richtlijnen ten aanzien van therapie (secretie-remmende of spasmolytische therapie).

Naast de contextuele factoren in de patiënttypen van 7 standaarden wordt in 10 andere melding gemaakt van contextuele factoren die van invloed kunnen zijn op het uitgestippeld diagnostisch pad zonder dat dit leidt tot een onderscheid in patiënttypen.

In 8 van de 27 diagnostische standaarden echter zijn de contextuele factoren afwezig of zonder meer summier te noemen. De standaard schouderklachten (M8) bijvoorbeeld maakt onderscheid in klachten met of zonder bewegingsbeperking ter bepaling van het diagnostisch beleid en prognose. Echter, een voor medici vrij duidelijk voorhanden zijn van de invloed van leeftijd, geslacht, co-morbiditeit (diabetes mellitus) of beroep op ontstaan en beloop van een schouderaandoening, wordt niet betrokken in de richtlijnen. In andere standaarden wordt weliswaar melding gemaakt van contextuele factoren die van belang zijn in de diagnostiek, maar wordt dit niet erg expliciet naar voren gebracht.

De meeste van deze standaarden geven in de anamnese primair richtlijnen ter uitdieping van de klacht en pas in tweede instantie een omschrijving van risicofactoren of oorzakelijke factoren aanwezig in de context van de klacht. De standaard perifeer arterieel vaatlijden bijvoorbeeld geeft in de sectie anamnese de volgende sequentie van richtlijnen:
Anamnese
"beloop van de klacht
"lokalisatie pijn, kramp of moe gevoel; claudicatio-afstand (PAV II)
"pijn in rust, tijdstip van optreden en lokalisatie van de pij̄n, bijzonderheden aan huid en nagels
(PAV III)
"necrose, grangeen (PAV IV)
"risicofactoren: roken, hypertensie, diabetes mellitus, hyperlipedemie, (hogere leeftijd, manne-
lijk geslacht)
medicatie: ergotamine, betablokker
"co-morbiditeit

In tegenstelling hiermee zijn de standaarden problematisch alcoholgebruik (M10) of ulçus cruris (Ḿ16) veel exlicieter. De standaarci problematisch aicoholmisbruik bij-

\footnotetext{
${ }^{1}$ In de standaard M8 (schouderklachten) worden de patiënttypen onderscheiden op het klinisch synairoom.
} 
voorbeeld geeft ten aanzien van diagnostiek een uitgebreide opsomming van meer dan 60 (!) risico-indicatoren die de huisarts alert moeten maken op de aanwezigheid van overmatig alcoholmisbruik.

Samenvattend onderscheiden dus slechts $27 \%$ van de standaarden patiënttypen met gevolgen voor de diagnostiek. Daarnaast is in ongeveer $37 \%$ van de standaarden een aangave van contextuele factoren met diagnostische invloed te vinden. De huisartsen in het onderzoek van Hofstra et al. gaven echter in iedere standaard al minimaal twee patiënttypen op basis van verschillen in contextuele factoren. Al met al ontstaat hiermee de indruk dat er een duidelijke discrepantie is tussen de structuur van de meeste standaarden zoals beleidsorganisaties die aanbieden en de feitelijke kennisstructuur van de huisartsen waarvoor zij bedoeld zijn. Acceptatie en implementatie van richtlijnen komen hierdoor onnodig in het gedrang. Implicatie van deze analyse is dat de invoering van de standaarden en de effectiviteit ervan waar het de verbetering van de huisartsgeneeskundige diagnostiek betreft wellicht aanzienlijk kan verbeteren wanneer bij de presentatie van standaarden expliciet aandacht wordt gegeven aan het onderscheid in de verschillende patiënttypen met behulp van contextuele informatie althans wanneer de inhoud van de standaard zich daarvoor leent.

\section{Implicaties voor de automatisering in de huisartsgeneeskunde.}

Een ander gebied waarop de resultaten van dit proefschrift implicaties kunnen hebben is dat van de automatisering in de huisartsgeneeskunde. Hierbij valt te denken aan de bestaande Huisarts Informatie Systemen (HIS) of nog te ontwikkelen expertprogramma's voor huisartsgeneeskundige diagnostiek.

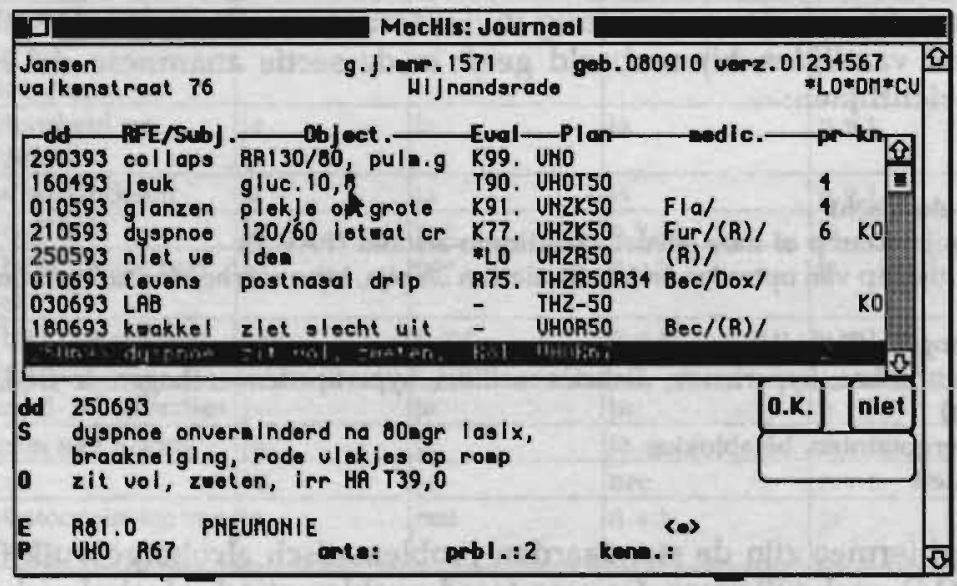

Figuur 7.1: Voorbeeld van een MacHIS Journaalscherm 
Het gegeven dat huisartsen intensief gebruik maken van contextuele informatie tijdens de beginfase van de diagnostiek zou gebruikt kunnen worden voor de verbeteringen aan bestaande HIS programma's. De huisarts heeft blijkbaar tijdens de anamnese en lichamelijk onderzoek grote behoefte aan informatie over zaken als voorgeschiedenis en medicatie. De bestaande HIS programma's hebben echter een weinig geïntegreerde architectuur. Dat wil zeggen dat de gegevens van de patient verdeeld is over verschillende schermen. Deze bevatten dan voornamelijk deelinformatie over een aspect van de totale patientinformatie. Dus (actuele en vroegere) klachten (het Journaalscherm) apart van bijvoorbeeld problemen (de Probleemlijst) of de medicatie (het Medicatiescherm). Slechts door het gericht oproepen van de probleemlijst, het risicoprofielscherm, het medicatiescherm of een ander lid uit hetzelfde woonverband krijgt men zicht op aanwezige contextuele informatie ${ }^{1}$ (zie figuur 7.1, 7.2 en 7.3).

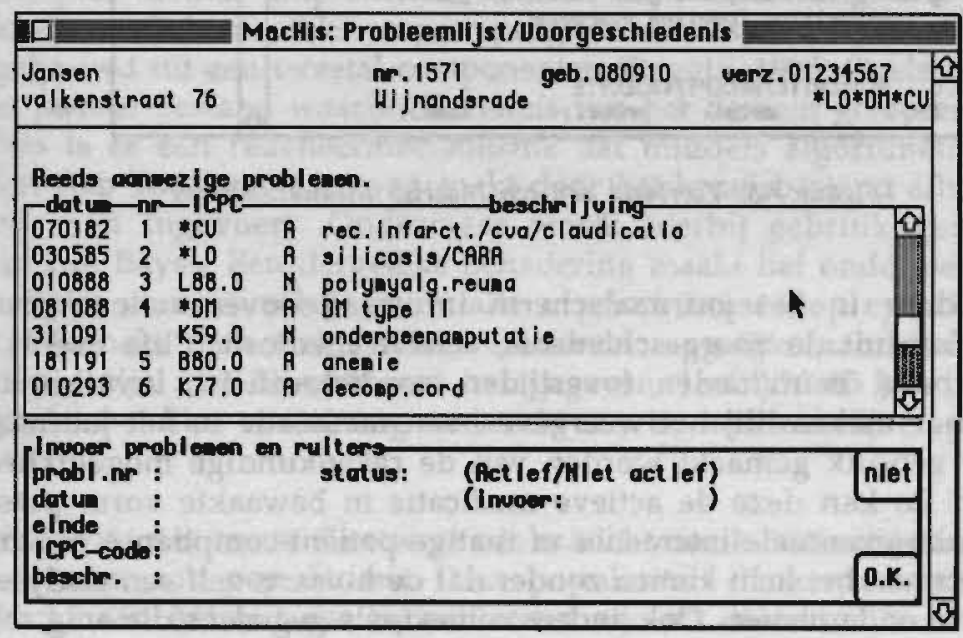

Figuur 7.2: Voarbeeld van een MacHIS Probleemlijstscherm

De huisarts zou idealiter tijdens de invoer in het journaalscherm direct de beschikking moeten hebben over (relevante) gegevens afkomstig uit de probleemlijst, de lijst van risicofactoren, de medicatielijst, de vroegere correspondentie of het bestand van een ander lid uit hetzelfde woonverband. Dit zou het diagnostisch denkproces

\footnotetext{
'Een uitzondering hierop vormt het aanwezig zijn van 'ruiters' die zichtbaar blijven in verschillende informatie-schermen. In de informatieschermen van de patient in figuur 7.1, 7.2, en 7.3 bijvoorbeeld zijn rechtsboven de ruiters ${ }^{*} \mathrm{LO}$ (cara), "DM (diabetes mellitus) en "CV (cardiovasculair) te zien. De laatste versie van MacHis bevat de keuzemogelijkheid uit 27 verschillende ruiters.
} 
van de huisarts ten goede komen. Daartoe moet veel van de huidige huisarts informatie systemen verbeterd worden.

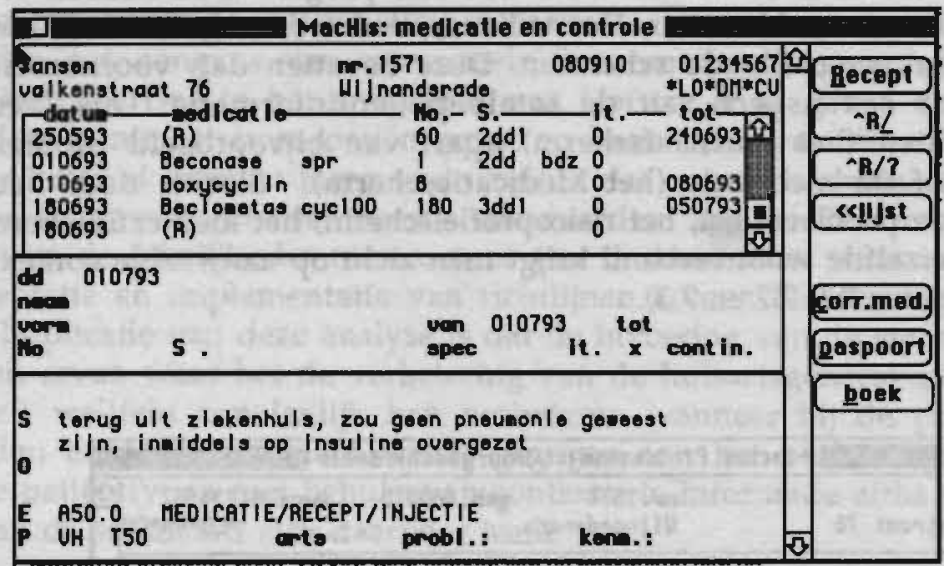

Figuur 7.3: Voorbeeld van een MacHIS Medicatiescherm

Bijvoorbeeld door in het journaalscherm informatie over actieve problemen, belangrijke zaken uit de voorgeschiedenis, actieve medicatie, 'life events' die het hele woonverband beïnvloeden (overlijden, werkeloosheid, invaliditeit, enzovoorts) zichtbaar maken. Bij het weergeven van medicatie in het journaalscherm kan dankbaar gebruik gemaakt worden van de rekenkundige mogelijkheden van een computer. Zo kan deze de actieve medicatie in bewaakte vorm presenteren. Hierdoor kunnen eventuele interacties of matige patiënt-compliance bij chronische medicatie direct aan het licht komen zonder dat de huisarts zelf een analyse in deze richting hoeft te ondernemen. Ook andere contextuele gegevens die enig rekenwerk nodig hebben kan de computer in het journaalscherm presenteren. Te denken valt bijvoorbeeld aan de frequentie waarmee een patiënt het spreekuur bezoekt, onafhankelijk van de hulpvraag danwel afhankelijk van de hulpvraag. Als men bijvoorbeeld een indruk wil krijgen van het ziektegedrag van een patiënt zou de huisarts middels een simpele zoekprocedure op klacht (bijvoorbeeld zoeken op 'hoesten' of 'verkoudheid') de frequentie daarvan met de daarbij gestelde diagnosen als contextuele informatie beschikbaar kunnen maken.

Met dergelijke ondersteuningsmogelijkheden betreedt men het terrein van de kunstmatige intelligentie (AI). Tot nu toe zijn voornamelijk expert programma's ontwikkeld ter ondersteuning van specialistische diagnostiek. Een voorbeeld hiervan is het AI-werk van de Dombal dat een ondersteuning biedt voor de diagnostiek van buikklachten zoals die zich aandienen bij de eerste hulppost van Engelse ziekenhuizen. Dergelijke programma's zijn in hun architectuur sterk gericht op de analyse van klachten, symptomen en laboratoriumuitslagen. Contextuele informa- 
tie die zo belangrijk is in de allereerste fase van de huisartsgeneeskundige diagnostiek komt in dergelijke programma's slechts zijdelings of pas op het einde van een analyseproces aan de orde. Met de ontwikkeling van expert programma's tracht men echter over het algemeen een analogie van de menselijke manier van redeneren te creëren. Het in dit proefschrift gepresenteerde onderzoek legt zo'n menselijke manier van redeneren bloot, en wel de manier waarop huisartsen op een efficiënte en effectieve wijze uit het zeer grote aantal van alle mogelijke ziekten (waarvan de meesten in hun vage vroege fase) een zinvolle selectie maken. Ontwikkelaars van kunstmatige intelligentie hebben grote behoefte aan methoden om het aantal keuzemogelijkheden binnen een programma te beperken. Ook daarom vormen de heuristieken die voor de bovenbeschreven sterke convergentiestappen verantwoordelijk zijn een interessant gegeven. Een en ander betekent dat indien huisartsgeneeskundige diagnostiek op computers nagebootst zal worden, al in het allereerste begin van het analyseproces met contextuele gegevens het aantal mogelijke hypothesen beperkt moet worden. Wil men dit idee op een 'gebruikelijke' manier implementeren dan stuit men al gauw op een aantal moeilijkheden. 'Gebruikelijke' expert programma's (symbol processing approach) zijn opgebouwd uit een tweetal componenten (Reggia, 1993; Steels, 1985). Enerzijds is er een passief bestand waarin de kennis van het domein gerepresenteerd wordt, anderzijds is er een redeneermechanisme dat middels algoritmen en statistische methoden stap voor stap een weg zoekt door het kennisbestand afhankelijk van de gegevens men ingevoert. Ondermeer wordt hierbij gebruik gemaakt van het theorema van Bayes. Een dergelijke benadering maakt het ondermeer noodzakelijk om van ieder contextueel gegeven alle a priori kansen op specifieke ziekten te kennen. Wanneer men zich realiseert hoeveel mogelijke aandoeningen alleen al geassocieerd zijn met bijvoorbeeld het gegeven 'leeftijd= 65 jaar', dan is al snel duidelijk dat het hier vooralsnog ontbreekt aan de noodzakelijke epidemiologische kennis.

Sinds 1985 wint het neurale netwerk als model voor kunstmatige intelligentie echter steeds meer aan populariteit. Deze populariteit danken dergelijke netwerken bijvoorbeeld aan het feit dat zij zelflerend zijn en daardoor in eerste opzet niet afhankelijk zijn van de beschikbaarheid van exacte gegevens zoals de kwantitatieve relatie tussen kenniselementen in de vorm van a priori kansen (Reggia, 1993). Associatieve verbanden tussen bijvoorbeeld een bepaald contextueel gegeven en een bepaalde diagnose hoeven niet per se kwantitatief bekend te zijn. Een ander voordeel van neurale netwerken boven de 'symbol processing approach' van de gebruikelijke expertprogramma's is, dat niet noodzakelijkerwijs vooraf bekend hoeft te zijn welke contextuele informatie van belang is in relatie tot een bepaalde diagnose. Is bij de invoer van een nieuwe patiënt een dergelijke factor aanwezig dan zal die bepaalde aandoening makkelijker geactiveerd worden. Een neuraal netwerk is daarom in staat om na een eerste opzet, waarin alleen wordt aangegeven welke contexten en diagnosen geregistreerd dienen te worden, tijdens het invoeren van patiënten een dergelijk connectie te vormen en de sterkte ervan te bepalen (en indien daartoe aanleiding is bij te stellen op basis van continue registratie). Met deze mogelijkheid kan ook tegemoet gekomen worden aan de verschillende sterkten in het verband tussen een bepaalde contextuele factor en een bepaalde 
ziekte afhankelijk van de lokale omstandigheden zoals platteland of stedelijke praktijkgebieden.

\section{Referenties}

Berwick, D.M., Fineberg, H.V. \& Weinstein, M.C. (1981). When doctors meet numbers. The American Journal of Medicine, 71, 991-998.

Boshuizen, H.P.A. (1989). De ontwikkeling van medische Expertise; Een cognitief-psychologische benadering. (Academisch proefschrift Rijsuniversiteit Limburg) Haarlem: Thesis Publishers.

Brooks, L.R., Norman, G.R. \& Allen, S.W.(1991). Role of specific similarity in a medical diagnostic task. Journal of Experimental Psychology, 120, 278-287.

Brown, J.S., Collins, A. \& Duguid, P. (1989). Situated cognition and the culture of learning. Educational Researcher, 18, 32-42.

Coughlin, L.D.J. (1986). The effect of randomization on the free recall of medical information by experts and novices. M. A. Thesis. Montréal, Canada: McGill University.

Custers, E.J.R.M., Boshuizen, H.P.A. \& Schmidt, H.G. (1993). The influence of typicality of case descriptions on subjective disease probability estimations. Paper presented at the Annual Meeting of the American Educational Research Association. Atlanta 12-16.

Elio, R. \& Scharf, P.B. (1990). Modeling novice-to-expert shifts in problem-solving strategy and knowledge organization. Cognitive Science, 14, 579-639.

Feltovich, P.J. (in press). Basic science knowledge and clinical practice. In J. Woolliscroft (Ed.). Proceedings of the Roll Conference on Medical Cognition.

Feltovich, P.J. \& Barrows, H.S. (1984). Issues of generality in medical problem solving. In H.G. Schmidt \& M.L. De Volder (Eds.), Tutorials in problem-based learning , (pp. 128-142), Assen, The Netherlands: Van Gorcum.

Gentner, D. \& Stevens, A.L. (1983). Mental Models. Hillsdale, NJ: Lawrence Erlbaum.

Gerritsma, J.G.M. \& Smal, J.A. (1982). De werkwijze van huisarts en internist; Een vergelijkend onderzoek met behulp van een interactieve patiëntensimulatie. (Academisch proefschrift Rijsuniversiteit te Utrecht) Utrecht: Wetenschappelijke Uitgeverij Bunge.

Grol, R. (1988). Deskundigheidsbevordering in de huisartsgeneeskunde. Van standaard tot ander handelen in de praktijk. Medisch Contact, 43(13), 395-399.

Grol, R. (1989). De verspreiding van NHG-standaarden onder huisartsen. Huisarts en Wetenschap, $32(13), 495-497$

Grol, R., Kistemaker, W. \& Hanrahan-Cahuzak, M. (1990). Invoering van consensusrichtlijnen. Preventie van ziekenhuisinfecties. Medisch Contact, 45(16) 517-523.

Grol, R., Tielens, V., Mokkink, H. \& Zwaard T. (1988).Ideaal of werkelijkheid? Problemen bij de ontwikkeling en invoering van standaarden. Huisarts en Wetenschap, 31, 392-397. 
Grol, A., Smits, A., Fransen, H., Huygen, F. \& van Weel, C. (1987). Continuilteit in de huisartsgeneeskunde. Huisarts en Wetenschap, 9, 275-280

Grol, R. \& Zwaard, A. (1989). Problemen bij de invoering van de NHG-standaard Orale Anticonceptie. Huisarts en Wetenschap, 32(13), 498-500.

Hassebrock, F. \& Prietula, M.J. (1990 april). Autobiographical memory in medical problem solving. Annual Meeting of the American Educational Research Association, Boston, MA.

Heerdink, C.F.M., Kaptein, A.A. \& Grol R. (1990) Protocolgebruik in de huisartspraktijk. Wat doen huisartsen met protocollen. Medisch Contact, 45, 717-720.

Hobus, P.P.M., Schmidt, H.G., Boshuizen, H.P.A. \& Patel, V.L. (1987). Contextual factors in the activation of first diagnostic hypotheses: Expert-novice differences. Medical Education, 21, 471 476.

Hofstra, M.L., Boshuizen, H.P.A., Grol, R.P.T.M., Hobus, P.P.MI., Meijer, M.E., Jacobs. J.C.G. (1993). Aansluiting van nascholing op het kennissysteem van huisartsen. Onderzoek naar specificiteit van richtlijnen binnen N.H.G.-standaarden. Bulletin Medisch Ondernijs,12, 65-72.

Joseph, G. \& Patel, V.L. (1987). Domain knowledge and medical problem solving: An on-line analysis. Paper presented at the Annual Meeting of the American Education Research Association. Washington, D. C., Montreal, Canada: McGill University. (Report CME87-CS9)

Joseph, G.M. \& Patel, V.L. (1990). Domain knowledge and hypothesis generation in diagnostic reasoning. Journal of Medical Decision Making, 10, 31-46.

Kanouse, D.E. \& Jacoby, I. (1988). When does information change practitioners' behaviour? Cambridge University Press, 27-33.

Knottnerus, J.A. (1986). Diagnostische hypothesen en a priori kansen in de huisartsgeneeskunde. Huisarts en Wetenschap, 29, 269-273.

Koedinger, K.R. \& Anderson, J.R. (1990). Abstract planning and perceptual chunks: Elements of expertise in geometry. Cognitive Science, 14, 511-550.

Kosecoff, J., Kanouse, D.E., Rogers, W.H., McCloskey, L., Winslow, C.M. \& Brook, R.H. (1987). Effect of the National Institutes of Health Consensus Development Program on physician practice. Journal of the American Medical Association, 258, 2708-2713.

Lamberts, H. (1991). In het huis van de huisarts. Verslag van het Transitieproject. Lelystad: MEDItekst

Lesgold, A.M. (1984). Acquiring expertise. In: J.R. Anderson, \& S.M.Kosslyn (Edsi.), Tutorials in learning and memory, (pp. 31-60), San Francisco/ New York: Freeman, W. H. \& Co.

Newell, A. \& Simon, H.A. (1972). Human problem solving. Englewood Cliffs, NJ: Prentice-Hall.

Norman, G.R., Brooks, L.R., Allen, S.W. \& Rosenthal, D. (1988). Improvement in medical knowledge unrelated to stable knowledge. Proceedings of the Cognitive Science Society Meeting. (pp. 482488), Hillsdale, New York: Lawrence Erlbaum.

Schank, R.C. \& Abelson, R.P. (1977). Scripts, plans, goals and understanding; An inquiry into human knowledge structures. Hillsdale, NJ, Erlbaum. 
Schmidt, H.G. \& Boshuizen, H.P.A. (1993). On acquiring expertise in medicine. Educational Psychology Review, 5, 1-17.

Schmidt, H.G., Boshuizen, H.P.A. \& Hobus P.P.M. (1988). Transitory stages in the development of medical expertise: The 'intermediate effect' in clinical case representation studies. Proceedings of the Cognitive Science Society Meeting. (pp. 139 - 145), Hillsdale, New York: Lawrence Erlbaum.

Schmidt, H.G., Boshuizen, H.P.A. \& Norman, G.R. (1992). Reflections on the nature of expertise in medicine. In Keravnou E. (Ed.), Deep Models for Medical Knowledge Engineering. Amsterdlam, The Netherlands: Elsevier.

Schmidt, H.G., Hobus, P.P.M., Patel, V.L. \& Boshuizen, H.P.A. (1987) Contextual factors in the activation of first hypotheses; Expert-novice differences. Paper presented at the Annual meeting of the American Educational Research Association, Washington.

Schmidt, H.G., Norman, G.R. \& Boshuizen, H.P.A. (1990). A Cognitive Perspective on Medical Expertise: Theory and Implications. Academic Medicine, 65, 611-621.

Sips, A.J.B.I. (1986). Protocollen voor de huisarts. Medisch Contact, 41(9), 277-279.

Steels, L. (1985). Tweede generatie expert systemen. Informatie, 11, 929-1032.

Reggia, J.A. (1993). Neural computation in medicine. Artificial Intelligence in Medicine, 5, 143-157.

Rethans, J.J.E. \& van Boven, C.P.A (1987). Simulated patients in general practice: a different look at the consultation. British Medical Journal, 294, 809-812.

Rethans, J.J., Sturmans, F., Drop, M.J., van der Vleuten, C.P.M. \& Hobus, P.P.M. (1991). Does Competence of general practitioners predict their performance? Comparison between examination setting and actual practice. British Medical Joumal, 303, 1377-1380. 


\section{SUMMARY}

The central proposition put forward in this thesis is that experienced doctors produce better diagnostic hypotheses than doctors with less experience, because they make more extensive use of contextual information about patients available to them. In this thesis we define contextual information as the additional information available to a doctor at the time when the patient expresses his complaint. This knowledge helps the medical practitioner restrict the number of possible diagnostic alternatives, given the complaint or the symptoms presented by the patient, to the number of probable ones. This may concern information which does not form an essential or sufficient condition for the development of a particular illness in a patient. It is therefore not essential for an underlying causal pathophysiological relationship to exist between the information which is already available about a patient and the present complaint or present clinical picture (although this may be the case, or at least such a causal relationship could be suspected). It is for this reason that we have referred to this kind of information as 'contextual information' in this thesis; it does not concern information which necessarily has a direct relationship with the clinical picture in question, but that is recognized by the experienced doctor in its context.

The theoretical basis for the study is provided by the idea that in diagnosing diseases, doctors have so-called illness scripts (Feltovich \& Barrows, 1984) at their disposal, i.e. cognitive structures in which their knowledge of certain diseases is organized. According to Feltovich and Barrows, these scripts consist of three elements: "enabling conditions," which we refer to here as contextual information; a "fault," the dysfunction of the organism and the pathophysiological mechanisms which result in this dysfunction; and "consequences," the results of the dysfunction as expressed in complaints and symptoms. Knowledge of the context and knowledge of the complaints and symptoms should together result in the identification of the dysfunction in the diagnostic situation.

In our opinion, knowledge of the context in which illness can arise is vitally important to the diagnosis, particularly for General Practitioners (GP's). Furthermore, in this thesis we assume that in the development of illness scripts, practical experience with diseases in all its forms is an important element. The more experience a doctor has with a particular illness, the more detailed his or her illness script will be for that disease and the more detailed in contextual information. In order to study these propositions, we carried out a number of experiments, summarized below.

In Chapter 2 an experiment is described in which 18 experienced GPs and 17 medical near or recent graduates of medical school were shown 32 sets of three slides. The 
first slide showed a photo of a patient, whose age and sex could be divined. The second slide showed the so-called "green card" which provides patient file information, such as place of residence, type of work, lifestyle, medication, previous illnesses and operations etc. The third slide comprised a brief description of a complaint or symptom, for example: "I became unwell on a number of occasions, my heart began to thump. And during the past few days I vomited a couple of times." The first two slides therefore provided contextual information about the patient. The slides were shown for a set amount of time. The task of the test subjects was, given this apparently very brief information about a patient, to formulate an initial diagnostic hypothesis. The correctness or incorrectness of this initial diagnostic hypothesis could be determined because the 32 patient descriptions were based on "real" patients, the nature of whose illness had been established with certainty. The results showed that experienced GPs, i.e. doctors with an average of 10 years experience, performed considerably better than the group of medical recent and near MD's. Using the information available, the experienced GPs made a correct diagnosis in almost $40 \%$ of the cases, while this was the case in $27 \%$ of the cases for the inexperienced doctors. The test subjects were later asked what information they remembered about the patients shown. It appeared that experienced doctors remembered on average $25 \%$ more information from the slides, indicating that they had processed this information more intensively in a cognitive way. The difference can be totally explained by the fact that experienced doctors remembered more relevant information pertaining to the illness; irrelevant information was not remembered better. From these findings, we concluded that the better diagnostic performance of experienced doctors can be explained by the fact that these doctors make more intensive use of contextual information in interpreting the complaint or symptom. Not only this is proved by the fact that relevant contextual information was remembered better; it is also supported by the fact that the amount of relevant information remembered correlated $0,63^{* *}$ with the correctness or incorrectness of the diagnosis (while irrelevant information remembered did not appear to be correlated with performance). These results suggest that expertise mainly seems to be a function of an abundant set of contextual knowledge related to the knowledge of symptoms and complaints associated with a particular illness. In discussions concerning this first experiment, it was noted that there may still be alternative explanations for the result. Given the set-up of the experiment, the possibility may not be excluded that the experienced doctors performed better, not because they made more intensive use of the contextual information, but, for example, because they have more detailed lists of possible diagnoses for a given complaint. It is possible that doctors develop a personal epidemiology which tells them which illness is most probable, given the nature of the complaint of symptom. Finding a causal relationship between the use of contextual information and diagnostic performance requires actual experimental manipulation of that contextual information.

Such an experiment is described in Chapter 3. In this second experiment, 16 experienced doctors and 16 inexperienced doctors were presented with 18 cases under two conditions. Eight experienced doctors and 8 inexperienced doctors were given the 18 cases with context, i.e. for each case they were shown the portrait, the green card and the complaint. The other 8 experienced and 8 inexperienced doctors were 
only shown the complaint. If experienced doctors make more intensive use of context, it should be expected that the omission of the context would have more effect on the performance of this group than on the performance of inexperienced doctors. The results supported this hypothesis. When the context in the form of the portrait and the green card was present, the experienced doctors formulated a correct diagnosis in no less than $54 \%$ of the cases. Where there was no context, this applied in only $31 \%$ of the cases on average. In addition the results showed that inexperienced doctors profit far less from the availability of context information: $26 \%$ as opposed to $19 \%$ correct diagnoses. The diagnostic performance of experts is therefore reduced by $23 \%$ when there is no context, while the performance of the inexperienced is reduced by a mere $7 \%$. It can therefore be concluded that the latter group does not utilize the information actually available to the maximum extent. $\mathrm{A}$ statistically significant interaction effect between expertise level and manipulation of the context supports this conclusion. As this experiment also reflected the same difference in performance as was found in the first experiment between experienced and inexperienced doctors, we concluded that the increasing use of contextual information is related to experience. Doctors learn to use contextual information as a result of their experiences with patients.

This proposition is aptly illustrated by a study described in Chapter 4. In this study diagnostic performance in the task used in the experiments discussed above was related to the number of years during which a doctor had been active in practice. There appeared to be a positive relationship between both variables. The Pearson product moment correlation coefficient was equal to 0.69 . This means that no less than $47 \%$ of the variance in performance between the participating doctors could be explained by the amount of experience they had, expressed in years in practice. Interestingly, a hypothesized linear relationship between both variables did not produce a lower correlation than a second order relationship which, based on intuition and on stories circulating among doctors, was more or less expected. This means that diagnostic expertise concerning the generation of diagnostic hypotheses increases linearly even after 30 years in practice.

Chapter 5 reports on experiment IV. Experiment II put us on the trail of the relative effect of context versus the complaint on diagnosis. After all, the results of that experiment showed that, already in response of the complaint alone, experienced doctors produce even better performances than unexperienced doctors. It was even the case that the experts in the experiment scored higher on the basis of the complaint alone than the "beginners" on the basis of complaint plus context (although the latter was not statistically significant). This leads us to question of the relative importance of both kinds of information in the formulation of a diagnosis. Is it the case that the diagnosis (or a number of diagnoses) is first generated by the complaint, and then its plausibility evaluated on the basis of context information? Or is it rather the other way round? Does context information perhaps suggest a number of possibilities which are then weeded out as the complaint information becomes available? In the latter case, context should have a broad "stage-setting" function instead of acting as a source of information against which concrete hypotheses can be tested. The plausibility of both views were tested in the following experiment. Experts and newly quali- 
fied doctors were confronted with 18 patient problems in the form of the familiar three slides. These slides were organized in two ways. Half of the test subjects were presented firstly with the complaint and then the context slides; the other half saw them in the order context-complaint. In addition to measuring diagnostic accuracy, the time used to produce them was also measured and subjects werelater asked what they could remember about the different cases. It was expected that if the complaint generated the diagnosis, while context mainly acted as a test pool, participating subjects under the condition complaint-context would perform better, i.e. they would require less time to study the case and would score significantly better as regards how much information relevant to the diagnosis they remembered. If, on the other hand, diagnoses were mainly generated by context information, then the information under the context-complaint condition would be processed more quickly and more information would have to be remembered under this condition (both relevant and irrelevant as regards the final diagnosis). Furthermore we hypothesized that if knowledge accessibility is the main factor, diagnostic accuracy will be better in the complaint-context order, provided scripts are exclusively triggered by the complaint. In contrast, when scripts are solely triggered by contextual information diagnostic accuracy will be better in the other presentation order. If knowledge availability is the most important factor that determines diagnostic performance, no effect of presentation order is expected.

However, no differences were discovered in the diagnostic performance of both expert groups, although again they produced significantly better diagnoses than the novices. This means therefore that the content of illness script knowledge is apparently more important than the way in which that knowledge is activated. The time necessary to generate a diagnose was significantly shorter in the condition where the complaint is presented before the contextual information. This suggests that diagnosis is indeed mainly generated by the complaint. However, technical shortcomings in the set-up of the experiment might have been the reason for this, partly because the results relating to the recall of the information which was relevant to the diagnosis do not support the above finding. The recall results rather provide arguments in favour of activation by contextual information. All in all, neither of the rival explanations could be excluded with this experiment. It is, however, clear that both the complaint and the contextual information activate relevant illness scripts. However, it is not clear which of the two sources of information do this most explicitly. The complaint seems to have more specific effects here than context:ual information. In relation to their less experienced colleagues, however, experienced GPs seemed to be intensively involved with forming a hypothesis even before the complaint was presented, without this diminishing their diagnostic superiority. In this process they mainly use information relating to the patient's medical history and use of medication. From the differences in speed and depth of the processing of relevant information in the condition where the contextual information was given prior to the complaint, we conclude that experienced GPs have a knowledge base containing many pre-existent illness scripts (probably several per diagnosis). They therefore seem more capable of activating correct illness scripts, purely on the basis of specific information in context, such as use of medication or previous medical history. 
Finally in Chapter 6 an attempt is made to study more directly the illness scripts which are assumed to lay the foundations for the superior diagnostic performance of experienced doctors. We used a narrative methodology for this. Doctors with various levels of expertise were presented 18 sets consisting of a complaint and a diagnosis and asked to describe a typical patient with this complaint and this diagnosis. The resulting protocols were analyzed according to the numbers of references to enabling conditions, faults and consequences. The data showed that the descriptions of the experts contained more contextual information (enabling conditions) and fewer references to the fault and to complaints and symptoms. These findings suggest that experienced doctors do have larger knowledge relating to the context of a disease than newly qualified doctors, even though the difference was smaller than expected, meaning that it cannot completely explain the great effects of context on diagnostic performance previously found. It may be that both experienced and inexperienced doctors have this knowledge, but that this knowledge only becornes functional, i.e. is only used, when under the influence of experience. A second finding was that the majority of the descriptions produced could be easily classified in the categories of the model of Feltovich and Barrows (1984). Even more interesting was the discovery that doctors also produced information relating to the treatment of the various complaints, although this had not been requested of them. This suggests that knowledge of diagnosis and treatment are part of the same script and are therefore activated simultaneously.

The research described in this thesis makes various contributions to further support the idea of illness script. In fact the studies discussed in this thesis mark the first attempts to empirically show the psychological reality of these cognitive structures. Although the concept of illness scripts, which form the basis on which doctors operate in routine cases, is almost commonplace in the community of researchers active in this field, this was not the case when this research was started, now seven years ago. The dominant view at that time was that experienced cloctors had a more extensive fund of knowledge than people with less expertise in a field, and this fact allowed experienced doctors to make a correct diagnosis by means of careful, "deep" reasoning. Pattern recognition, now generally seen as the main characteristic of real expertise, was then considered a risky business which doctors should avoid. An initial contribution provided by the research described in this thesis to the development of the theory is therefore the idea that the knowledge on which doctors operate in routine cases, has a script structure and that knowledge which is organized in these scripts is rather clinical than causal biomedical.

A second contribution of our research is that it has focused attention on the great significance of the context in which an illness develops for its diagnosis. As has been shown in the study presented here, contextual cues belong to the schemes which experts use to understand their world. The research is related to the recent cognitive-psychological stream called "situated cognition." This approach calls attention to the fact that human cognition is strongly linked to situations in which that cognition is functional. One of the consequences of this concept is that 
knowledge and skills should be learned as far as possible in that situation in which such knowledge and skills must be applied.

A third contribution is that illness scripts can be satisfactorily described with Feltovich and Barrows' division into enabling conditions, fault and consequences. The study discussed in Chapter 6 showed that patient descriptions generated by doctors can be easily classified in these categories. Furthermore, this research has provided a new empirical and experimental method for studying the knowledge structures of doctors. Experimental manipulation of variables regarded as being of theoretical importance makes it possible to understand in greater detail what expertise is and how it develops. It was the Maastricht group which first introduced such manipulations in research into medical expertise. In addition the narrative method used in Chapter 6 is very suitable to elicit illness script knowledge directly.

With the results of experimental scientific research described in this thesis, we feel that a number of other important features of medical practitioner's diagnostics have also been highlighted. In no other discipline in health care can a doctor be confronted with such a great diversity of illnesses. We think that in order to be able to provide diagnoses for a wide range of different illnesses the mechanisms and particular changes in medical knowledge described in this thesis develop.

This thesis may provide a contribution to the improvement of diagnostic guidelines for the medical practitioner as contained in the standards policy of the Dutch General Practitioners Society (Nederlands Huisarts Genootschap). The application of standards by GPs in daily practice is sparse for many reasons, some of which are not always clear. One of the reasons could be that they do not parallel the "natural" thinking process of GPs. Most standards first give guidelines how to analyse the complaint and second describe risk factors or causal factors available in the context of the complaint. In $64 \%$ of the standards there is a reference to contextual factors with diagnostic implications. This creates the impression that there is a discrepancy between the structure and content of most of the standards as provided by policy organizations and the actual knowledge structure of the GPs as shown in this thesis. Acceptation and implementation of guidelines therefore suffer unnecessarily. If standards contained more explicit references to contextual factors preferable at the beginning of the standard, this would bring the guidelines for diagnostic more into line with the actual way of thinking.

Another area in which the results of this thesis may have implications is that of automation in medical practice, such as the existing Medical Practitioners' Information Systems [Huisarts Informatie Systemen: HIS] or yet to be developed expert programs for medical practitioners' diagnostics. The fact that GPs make intensive use of contextual information during the initial phase of the diagnostic process should be used for improving existing HIS programs. Ideally the GP should, during input of present complaints, have direct access to (relevant) data from problem list, list of risk factors, medication list, previous correspondence, or the file of another member of the same family. The existing HIS programs, however, have an architec- 
ture that does not allow this flexibility. This means that every screen page (the problem list or medication list or previous correspondence) contains mainly incomplete information about the patient. Any contextual information present in the problem list, risk profile list, medication list or the file of another member of the same family can only be seen by calling up this information using special codes. Improvements could be made here. It would be useful for a GP if the input screen. from the patients record directly showed contextual factors such as: active problems from the problem list, important details from previous history, active medication, a number of risk factors or "life events" which affect a whole family. With regard to medication information, good use can be made of the possibilities which can be offered by a computer, for example the presentation of the active medication, monitored by a support system to detect patient compliance or drug interaction.

The results described in this thesis can also be useful in the development of expert programs to support medical practitioners' diagnostic process. Up until now only expert programs have been developed to support specialist diagnostics. Contextual information which is so important in the very first phase of medical practitioners' diagnostics is only briefly included in such programs or is only referred to at the end of an analysis process. If the diagnostic process of the GP is to be simulated on computers, at the very start of the analysis process, the number of possible hypotheses will have to be limited with the help of contextual data. In this respect the possibilities of a neural network can offer the most suitable architecture. 


\section{DANKWOORD}

Ook bij de totstandkoming van dit proefschrift waren vele personen betrokken. Aan al deze ben ik dank verschuldigd.

Allereerst aan mijn promotor en co-promotor, Henk Schmidt en Els Boshuizen. Zij gaven mij inzicht in de meest recente opvattingen over medisch diagnostisch denken en in het uitvoeren van daarop toegesneden cognitief psychologisch onderzoek. Als begeleider en kamergenoot stimuleerden en vormden zij permanent mijn wetenschappelijke aspiraties met het onderhavige proefschrift als resultaat.

Ten tweede ben ik dank verschuldigd aan alle huisartsen, basisartsen en bijnabasisartsen die als proefpersonen bereid waren hun 'diagnostische ziel' bloot te geven.

Metta, ik vind het jammer dat je niet in de gelegenheid bent mij bij te staan als paranymf. Ik wil je danken voor je persoonlijke inzet gedurende het jaar dat je als huisartsonderzoeker aan dit project verbonden was.

Ook mede-huisartsonderzoekers Peter Freens en Jan-Joost Rethans hebben mij gevraagd en ongevraagd, geholpen en becommentarieerd.

Wim Boersma hielp bij de selektie van casuistiek. Bart Hermens en Hans van Dijk van de audiovisuele dienst voorzagen mij van de benodigde equipment om de casus te presenteren.

De hulp van Bert Kerkhofs bij de analyse van de data van experiment I was onontbeerlijk, evenals de technische ondersteuning van Gerrie van Wunnik bij experiment III.

Bij het uitwerken en scoren van de protocollen van experiment IV heb ik veel hulp gehad van Iris, Petra en Otto.

Heribert Korten en Frances Clark leverden in de eindfase van dit proefschrift belangrijke taalkundige bijdragen.

Verder wil ik alle leden van de vakgroepen huisartsgeneeskunde en onderwijsontwikkeling en onderwijsresearch bedanken voor de hulp en ondersteuning gedurende mijn verblijf in hun gelederen.

Tot slot enkele opmerkingen betreffende het gezinsleven van een promovendus: Tiba, jouw intra-uteriene groeisnelheid heeft mij opgedweept. Ik heb geprobeerd je in te halen, maar blijkbaar zag jij gemakkelijker het licht dan mijn pennevrucht. Oumelaïd jij zult blij zijn dat 'het' af is en ik ben blij dat ik niet meer zo vaak naar 'mijn hok' moet. 


\section{CURRICULUM VITAE}

05-04-1956 Geboren te Roggel (L).

1968-1974 Atheneum B Bisschoppelijk College te Roermond.

1974-1980 Studie Geneeskunde, Rijksuniversiteit Limburg te Maastricht.

1980 Agnio Verloskunde (prof. dr. J. de Haan), Academisch Ziekenhuis te Maastricht.

1980 Onderwijsontwikkelings werkzaamheden, Suez Canal University te Ismailia (Egypte).

1981 Agnio Algemene Heelkunde (prof. dr. J.M. Greep), Academisch Ziekenhuis te Maastricht.

1981-1982 Opleiding Huisartsgeneeskunde, Rijksuniversiteit Limburg te Maastricht.

1983 Vaardigheidsdocent, Rijksuniversiteit Limburg te Maastricht.

1983-1985 Wisselassistentschap: afdeling Interne Geneeskunde, Intensive Care, Algemene Heelkunde, EHBO, Gynaecologie en Verloskunde in het St. Jozef Ziekenhuis te Gouda.

1985 - 1986 Huisartsonderzoekersopleiding, Vakgroep Huisartsgeneeskunde van de Rijksuniversiteit Limburg te Maastricht.

1985 - 1991 Huisartsonderzoeker, Vakgroep Onderwijsontwikkeling en Onderwijsresearch van de Rijksuniversiteit Limburg te Maastricht. Onderzoek naar de invloed van ervaring op de kwaliteit van het diagnostisch denken van huisartsen.

1985 - 1988 Huisarts-assistent (drs. M. Op den Kamp), te Heerlen.

1988 - Zelfstandig gevestigd huisarts te Wijnandsrade (L). 


\section{Expertise van huisartsen}

\section{Praktijkervaring, kennis en diagnostische hypothesevorming}

Pie Hobus

Al heel vroeg in een consult ontwikkelt de huisarts diagnostische hypothesen omtrent de aard van de aandoening van de patiënt. Deze hypothesen bepalen in hoge mate het verdere beloop en de uitkomst van het diagnostisch proces. Maakt de huisarts daarbij gebruik van zijn voorkennis over die patiënt? Waarom zijn diagnostische hypothesen van ervaren artsen beter dan die van onervaren collega's? Op deze vragen geeft dit boek onder meer een antwoord. De auteur doet verslag van experimenteel onderzoek naar factoren die het mentale zoekproces in de allereerste fase van het consult beïnvloeden. Deze consultfase wordt door middel van diapresentaties gesimuleerd. Met behulp van methoden uit de cognitieve psychologie wordt het diagnostisch denken van de deelnemende artsen nader onderzocht. De resultaten van de viff beschreven experimenten dragen bij aan een fundamenteel beter inzicht in het diagnostische denken van huisartsen. Dit kan implicaties hebben voor het medisch onderwijs, kwaliteitsbevordering en automatisering in de huisartsgeneeskunde.

Pie Hobus studeerde geneeskunde aan de Rijksuniversiteit Limburg te Maastricht. Van 1985 tot 1991 was hij hier als huisarts-onderzoeker verbonden aan de vakgroep Onderwijsontwikkeling en Onderwijsresearch. Sinds 1988 is hij gevestigd als zelfstandig huisarts.

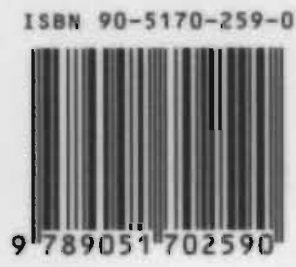

